\title{
WATER RESOURCES OF LINCOLN COUNTY, WYOMING
}

By Cheryl A. Eddy-Miller, Maria Plafcan, and Melanie L. Clark

\section{U.S. GEOLOGICAL SURVEY}

Water-Resources Investigations Report 96-4246

Prepared in cooperation with the Wyoming State Engineer

Cheyenne, Wyoming 


\title{
U.S. DEPARTMENT OF THE INTERIOR BRUCE BABBITT, Secretary
}

\author{
U.S. GEOLOGICAL SURVEY \\ Gordon P. Eaton, Director
}

The use of trade, product, industry, or firm names is for descriptive purposes only and does not imply endorsement by the U.S. Government.

For additional information write to:

District Chief

U.S. Geological Survey, WRD

2617 E. Lincolnway, Suite B

Cheyenne, Wyoming 82001-5662
Copies of this report can be purchased from:

U.S. Geological Survey Branch of Information Services Box 25286, Denver Federal Center Denver, Colorado 80225 


\section{CONTENTS}

Abstract

Introduction

Purpose and scope

Climate

Generalized geologic history

Water-right administration

By Richard G. Stockdale, Wyoming State Engineer's Office ……........................................................... 7

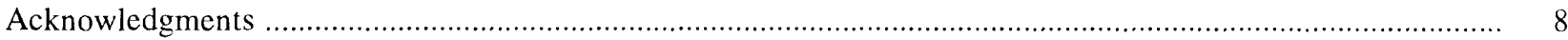

Streamflow

Streamflow data

Streamflow characteristics

Average annual runoff .....

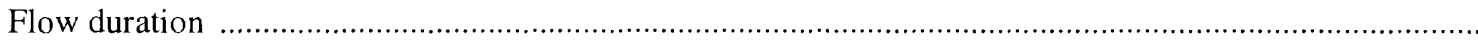

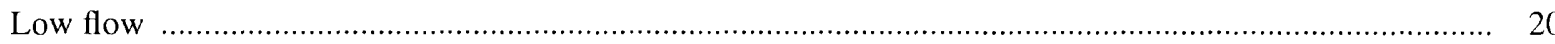

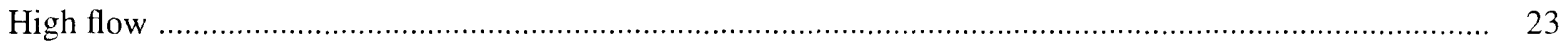

Ground water

Ground-water data

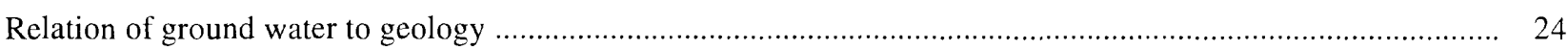

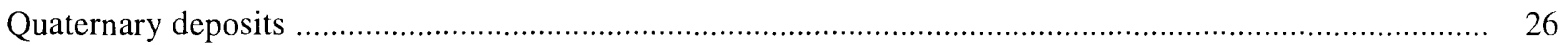

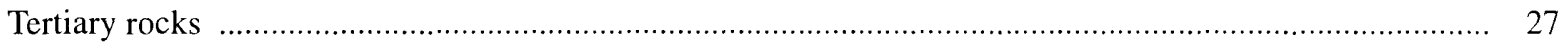

Mesozoic rocks

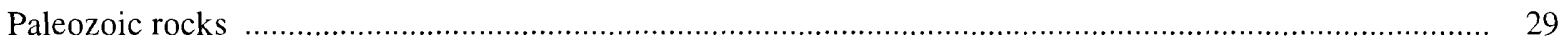

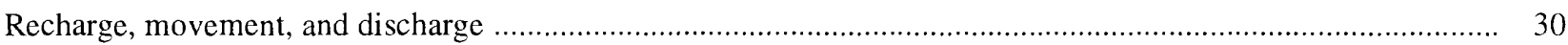

Water use

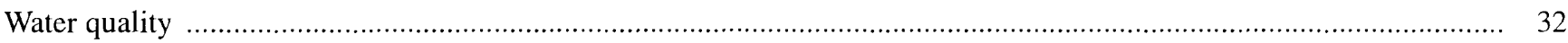

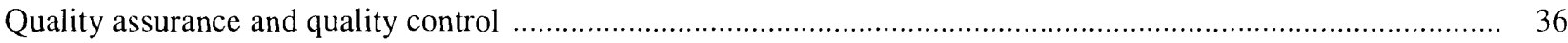

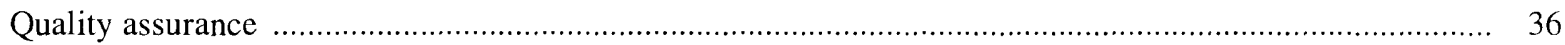

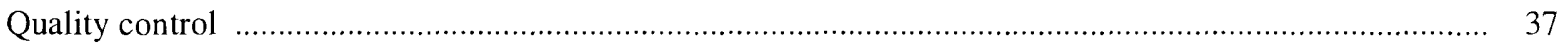

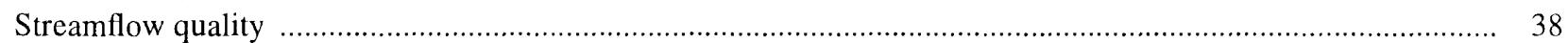

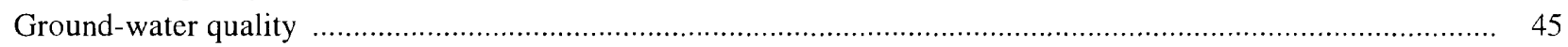

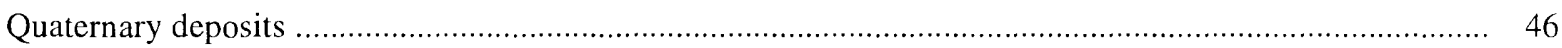

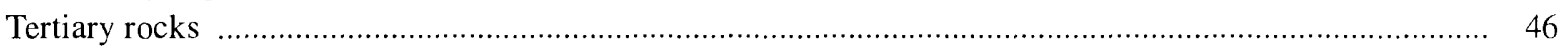

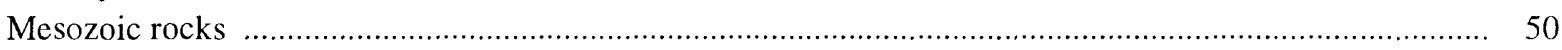

Paleozoic rocks

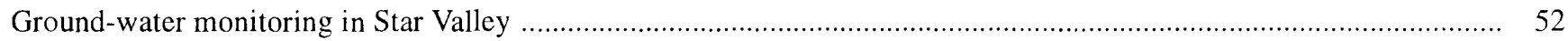

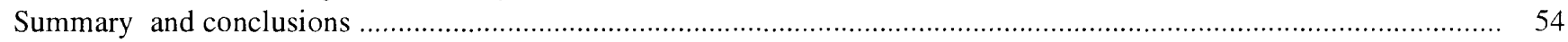

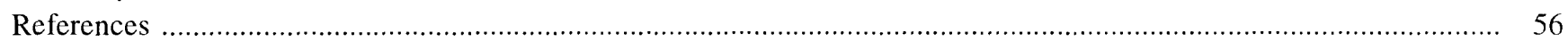

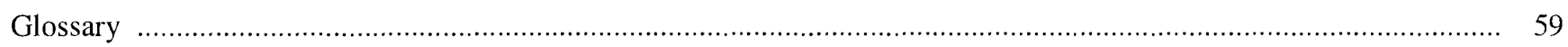

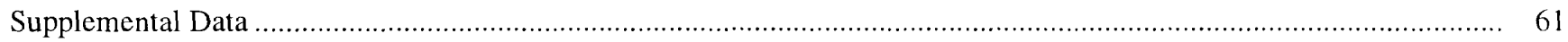

\section{PLATES [plates are in pocket]}

1. Geologic map of Lincoln County, Wyoming

2. Map showing locations of selected streamflow-gaging and reservoir-content stations and miscellaneous streamflow sites in Lincoln County, Wyoming

3. Map showing locations of wells and springs inventoried in Lincoln County, Wyoming 


\section{FIGURES}

1. Map showing location and physiography of Lincoln County, Wyoming

2. Map showing mean annual precipitation for Lincoln County, Wyoming, 1951-80.

3. Graph showing mean monthly precipitation and air temperatures at Fontenelle Dam (1963-80) and town of Afton (1951-80), Lincoln County, Wyoming

4. Sketch showing procedure for collection of streamflow data at a gaging station

5. Graph showing daily mean discharge for an ephemeral/intermittent stream and a perennial stream, water year 1967

6. Graph showing flow-duration curves of daily mean discharge for Hams Fork below Pole Creek near Frontier, Lincoln County, Wyoming, and Pacific Creek near Farson, Sweetwater County, Wyoming

7. Diagram showing systems for numbering wells and springs

8. Map showing location of the Green, Bear, and Snake River drainage areas in Lincoln County, Wyoming ........

9. Map showing location of streamflow data collection sites on the Salt River and a tributary to the Salt River sampled July 18-23, 1994

10. Box plots showing distribution of dissolved-solids concentrations in water samples collected from wells completed in and springs issuing from selected geologic units in Lincoln County, Wyoming

11. Modified Stiff diagrams showing major cations and anions in selected water samples collected from wells completed in and springs issuing from selected geologic units in Lincoln County, Wyoming .........

12. Map showing general location of Quaternary deposits, Tertiary rocks, and Mesozoic and Paleozoic rocks in Lincoln County, Wyoming

13. Map showing location of wells used in the Star Valley monitoring study, Idaho and Wyoming

\section{TABLES}

1. Selected streamflow-gaging and reservoir-content stations in Lincoln County, Wyoming ................................. 10

2. Selected miscellaneous streamflow sites in Lincoln County, Wyoming .......................................................... 14

3. Streamflow characteristics at selected streamflow-gaging stations in Lincoln County, Wyoming........................ 17

4. Seven-day low-flow discharges for selected streamflow-gaging stations in Lincoln County, Wyoming ................ 22

5. Estimated ground water, surface water, and total water use in Lincoln County, Wyoming, 1993 ........................ 31

6. Source or cause, and significance of dissolved-mineral constituents and physical properties of water .................. 33

7. Wyoming ground-water quality standards for domestic, agricultural, and livestock use .................................. 36

8. Selected maximum and secondary maximum contaminant levels for public drinking-water supplies .................. 37

9. Statistical summary of selected physical properties and chemical analyses of water samples collected from streams and rivers in the Green, Bear, and Snake River Basins, Lincoln County, Wyoming.

10. Statistical summary of seasonal nitrite plus nitrate data from ground-water samples collected during the Star Valley monitoring study, 1993-95, Lincoln County, Wyoming ....................................................... 54

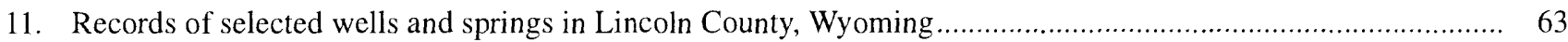

12. Lithologic and water-yielding characteristics of geologic units in Lincoln County, Wyoming .......................... 75

13. Instantaneous discharge, physical and biological properties, and chemical analyses of water samples collected at streamflow sites on the Salt River and a tributary to the Salt River, sampled July 18-23, 1994, Idaho and Wyoming

14. Physical properties and chemical analyses of water samples collected from wells completed in and springs issuing from selected geologic units in Lincoln County, Wyoming.....

15. Concentrations of selected trace elements in water samples collected from wells completed in and springs issuing from selected geologic units in Lincoln County, Wyoming.....

16. Physical properties and chemical analyses of ground-water samples collected from wells sampled during the Star Valley monitoring study, 1993-95, Lincoln County, Wyoming..... 


\begin{tabular}{|c|c|c|}
\hline Multiply & By & To obtain \\
\hline acre & 4,047 & square meter \\
\hline acre & 0.4047 & hectare \\
\hline acre-foot (acre-ft) & 1,233 & cubic meter \\
\hline acre-foot (acre-ft) & 0.001233 & cubic hectometer \\
\hline cubic foot per second $\left(\mathrm{ft}^{3} / \mathrm{s}\right)$ & 0.02832 & cubic meter per second \\
\hline $\begin{array}{l}\text { cubic foot per second per square } \\
\text { mile }\left[\left(\mathrm{ft}^{3} / \mathrm{s}\right) / \mathrm{mi}^{2}\right]\end{array}$ & 0.01093 & $\begin{array}{l}\text { cubic meter per second per } \\
\text { square kilometer }\end{array}$ \\
\hline foot $(\mathrm{ft})$ & 0.3048 & meter \\
\hline gallon & 0.003785 & cubic meter \\
\hline gallon per minute (gal/min) & 0.06309 & liter per second \\
\hline inch (in.) & 25.4 & millimeter $(\mathrm{mm})$ \\
\hline inch per year (in/yr) & 25.4 & millimeter per year \\
\hline mile $(\mathrm{mi})$ & 1.609 & kilometer \\
\hline million gallons (Mgal) & 3,785 & cubic meter \\
\hline square mile $\left(\mathrm{mi}^{2}\right)$ & 2.59 & square kilometer \\
\hline
\end{tabular}

Temperature can be converted to degrees Fahrenheit $\left({ }^{\circ} \mathrm{F}\right)$ or degrees Celsius $\left({ }^{\circ} \mathrm{C}\right)$ as follows:

$$
\begin{aligned}
& { }^{0} \mathrm{~F}=9 / 5\left({ }^{\circ} \mathrm{C}\right)+32 \\
& { }^{\circ} \mathrm{C}=5 / 9\left({ }^{\circ} \mathrm{F}-32\right)
\end{aligned}
$$

Sea level: In this report, "sea level" refers to the National Geodetic Vertical Datum of 1929--a geodetic datum derived from a general adjustment of the first-order level nets of the United States and Canada, formerly called Sea Level Datum of 1929.

\section{Abbreviated water-quality units used in this report:}
$\mathrm{meq} / \mathrm{L}$
milliequivalents per liter
$\mathrm{mg} / \mathrm{L}$
milligram per liter
$\mu \mathrm{g} / \mathrm{L}$
microgram per liter
$\mu \mathrm{m}$
micrometer
$\mu \mathrm{S} / \mathrm{cm}$
microsiemens per centimeter at 25 degrees Celsius

\section{Abbreviations used in this report:}

$\mathrm{MCL}$

NAWQA

NWQL

SMCL

USEPA

USGS

maximum contaminant level

National Water Quality Assessment Program

National Water Quality Laboratory of U.S. Geological Survey

secondary maximum contaminant level

U.S. Environmental Protection Agency

U.S. Geological Survey 


\title{
WATER RESOURCES OF LINCOLN COUNTY, WYOMING
}

\author{
By Cheryl A. Eddy-Miller, Maria Plafcan, and Melanie L. Clark
}

\begin{abstract}
Surface-water, ground-water and water-quality data were compiled to describe the general occurrence, availability, and chemical quality of the water resources of Lincoln County, Wyoming. These data are needed to plan for and to manage the increased demands for water in the county. This study was conducted in cooperation with the Wyoming State Engineer.

The average annual runoff varied for the two hydrologic regions that occur in Lincoln County. In the Mountainous Region, average annual runoff ranged from 1.05 to 40 inches per year. Although no streamflow-gaging stations in the county were identified as receiving most of their flow from the High Desert Region, this type of stream does exist in the county. At a gaging station located 40 miles east of the county in the High Desert Region, the average annual runoff was 0.1 inch per year.
\end{abstract}

Geologic units were grouped mainly by age, and include deposits of Quaternary age, and rocks of Tertiary, Mesozoic, and Paleozoic age. Rocks of Precambrian age are not exposed at the surface in Lincoln County. More wells were developed in Quaternary deposits than any other geologic unit in the county. The most productive alluvial and colluvial aquifers in the Overthrust Belt, with pumping wells discharging up to 2,000 gallons per minute, are located in the valleys of the Bear River and Salt River (Star Valley).

Ground-water movement is related to the location of the recharge and discharge areas and to the thickness and permeability of aquifer materials. The ground-water connection between areas in the Overthrust Belt and the Green River Basin is restricted by folded and faulted rocks that are a result of regional tectonic (or orogenic (mountain building)) activity during middle Mesozoic and early Cenozoic time. Ground-water movement is difficult to define by aquifer within the Overthrust Belt because of the numerous faults and fractures. Most of the water discharged from the major limestone and dolomite aquifers of the Paleozoic (including the Madison Limestone of Mississippian age, Darby Formation of Devonian age, and the Bighorn Dolomite of Ordovician age) in the Overthrust Belt is from large springs. Water recharging these aquifers in one surface drainage basin may discharge in another drainage basin via interbasin transfers of ground water.

Total water use in Lincoln County during 1993 was estimated to be 405,000 million gallons. Surface water was the source for about 98 percent of the water used in the county; ground water accounted for about 2 percent of the water used. Hydroelectric power generation and irrigation used the largest amount of water.

Discharge measurements and surface-water samples were collected from the Salt River and one tributary to the Salt River during a streamflow sampling event in Star Valley, July 18-23, 1994. During that time, the river had an overall gain of 340 cubic feet per second along the reach from the Salt River's entrance into Star Valley to where the river discharges into Palisades Reservoir. 
Dissolved-solids concentrations varied greatly for ground-water samples collected from 35 geologic units. Dissolved-solids concentrations in all water samples collected from the Laney Member of the Green River Formation of Tertiary age were greater than the Secondary Maximum Contaminant Level of 500 milligrams per liter established by the U.S. Environmental Protection Agency. All ground-water samples collected from the Salt Lake and Teewinot Formations of Tertiary age, the Madison Limestone of Mississippian age, and the Bighorn Dolomite of Ordovician age contained dissolved-solids concentrations less than the Secondary Maximum Contaminant Level.

Increased population growth in Star Valley and recent detections of nitrate concentrations above the maximum contaminant level of 10 milligrams per liter as nitrogen, established by the U.S. Environmental Protection Agency, prompted a study of the baseline water quality of the ground water. Ten domestic wells completed in the Salt River alluvium and colluvium were established as monitoring wells in 1993. A total of 84 ground-water samples were collected from the wells used in the Star Valley monitoring study. No water sample had a nitrate concentration greater than the maximum contaminant level. Statistical analysis indicated there was no significant difference between the water quality data collected in different seasons, and no correlation between the nitrate concentrations and the depth to ground water.

\section{INTRODUCTION}

Lincoln County was established February 20, 1911 with land partitioned from Uinta County. In 1921, Lincoln County was reduced to the current 4,182 square miles when Teton and Sublette Counties were created, making Lincoln the 11th largest county in Wyoming (Wyoming Historical Records Survey, 1941, p. 1) (fig. 1). Lincoln County development was primarily due to mining, westward expansion, and settlement by the Church of Jesus Christ of Latter-day Saints (Wyoming Historical Records Survey, 1941). Water is and has been a critical resource during the development of the county, especially for irrigation and mining use. Construction of canals in Star Valley, which were essential for crop production, was started in 1889 (Corsi, 1990). The county's population according to the 1990 census is 12,625 (Wyoming Data Handbook, 1991, p. 250). Most of the current population is divided between the Kemmerer area and Star Valley.

The topography of the county ranges from the flat intermontane Star Valley in the north-western part of the county; rises quickly to high mountains in the central part of the county; and returns to flat, arid, sage and grasslands in the southern and eastern part of the county. Altitudes range from 5,600 feet near Star Valley to 11,378 feet at the top of Wyoming Peak. The Green, Bear, and Snake Rivers are the principal rivers providing surface-water drainage in the county. Currently, water in the county is used mostly for power generation, agriculture, industry, public supply, and domestic use.

\section{Purpose and Scope}

The purpose of this report is to determine and describe the general occurrence, availability, and chemical quality of surface and ground water of Lincoln County, Wyoming. The information presented can be used in management of the water resources, including planning and designing new water supplies and related economic developments. This report, prepared in cooperation with the Wyoming State Engineer, is one of a series of reports describing the water resources of selected Wyoming counties.

The principal water resources in the county are streamflow and ground water. Streamflow is described first, but the emphasis is on ground water. The relation of ground water to geology is described, as well as ground-water recharge, movement, and discharge. A geologic map was compiled for Lincoln County (pl. 1). 


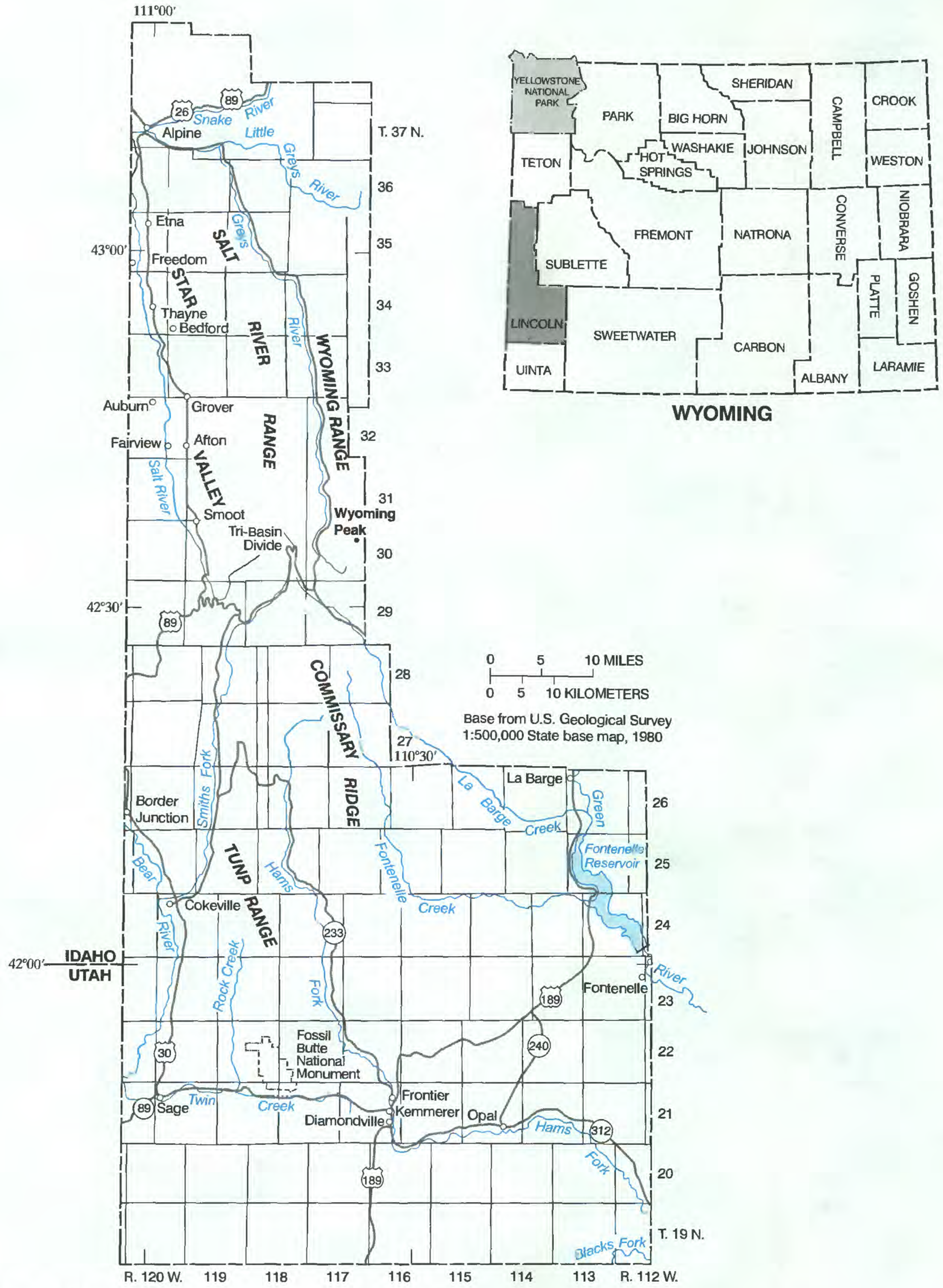

Figure 1. Location and physiography of Lincoln County, Wyoming. 
Streamflow (pl. 2) and ground-water (pl. 3) sites were inventoried and sampled for this study from 1993 to 1995 to improve data coverage of the county. In 1994, chemical characteristics and discharge data were collected at 10 sites on the Salt River and one tributary to the Salt River. The ground-water inventory consisted of collecting data at 191 wells and springs during 1993-95, in addition to analyzing the existing data in the U.S. Geological Survey data bases.

\section{Climate}

The climate of Lincoln County varies in response to altitude, season, and topographic features. Precipitation in the county ranged from less that 8 inches per year in the southeastern part of the county to an estimated 60 inches in the Wyoming Range during the period of 1951-80 (fig. 2). A weather station at the dam on Fontenelle Reservoir records an average 6.5 inches of precipitation per year in contrast to the station of similar elevation near the Afton that records an average 18 inches of precipitation per year (fig. 3). This difference is attributed to the southeastern part of the county being in a rain shadow, a dry region on the lee side of the Salt River and Wyoming Ranges. Most of the southeastern part of the county receives less than 10 inches of precipitation, and is classified as desert (Martner, 1986, p. 6). The precipitation estimate for the Wyoming Range is based on correlations of annual precipitation with snowpack measurements and terrain factors, such as altitude, and should be regarded with caution (Martner, 1986, p. 78). The estimates are included to show the variability of precipitation with respect to large changes in altitude that occur in the county.

Temperatures in Lincoln County vary mainly in response to changing seasons. Mean monthly air temperatures were recorded at six weather stations located around the county (Afton, Bedford, Sage, Kemmerer, La Barge, and the dam at Fontenelle Reservoir). The temperatures recorded at these stations vary an average of $4^{\circ} \mathrm{F}$ between the stations at any given time throughout the year. However, the mean monthly temperature at the six stations varies an average of $47^{\circ} \mathrm{F}$ between winter and summer (Martner, 1986).

\section{Generalized Geologic History}

Lincoln County has two distinct geologic terrains, the Overthrust Belt in the western part of the county and the Green River Basin in the eastern part. The north-south trending Darby Thrust Fault separates the regions (pl. 3) (Ahern and others. 1981, fig. II-5). The central and western parts of the county include part of the Overthrust Belt and are characterized by north-south trending mountain ranges and valleys. The eastern part of the county includes a portion of the Green River Basin, which is an intermontane basin characterized by high plains, plateaus, and dissected terrain. Descriptions of the geology of the Overthrust Belt and Green River Basin in this report are limited to the deposits within Lincoln County.

A geologic map of Lincoln County is shown on plate 1. Igneous and metamorphic basement rocks of Precambrian age consisting of granite-gneiss, schist, granite, and pegmatite underlie the Overthrust Belt and the Green River Basin but are not exposed at the surface. Surficial geologic units in the Overthrust Belt range from sedimentary rocks of Cambrian age to unconsolidated deposits of Quaternary age. Surficial geologic units in the Green River Basin range from sedimentary rocks of Tertiary age to unconsolidated deposits of Quaternary age.

Sedimentary rock sequences of Paleozoic and Mesozoic age were deposited by alternating transgressive and regressive seas. In Lincoln County, these rocks are composed mainly of limestone, dolomite, siltstone, sandstone, conglomerate, mudstone, and shale. The Flathead Sandstone, Gros Ventre Formation, and the Gallatin Limestone of Cambrian age are examples of formations deposited by transgressive seas. Mesozoic rocks in the county were deposited in environments ranging from continental shelf to continental. The continental shelf depositional environment occurs between the shoreline and deep ocean. Continental deposits 


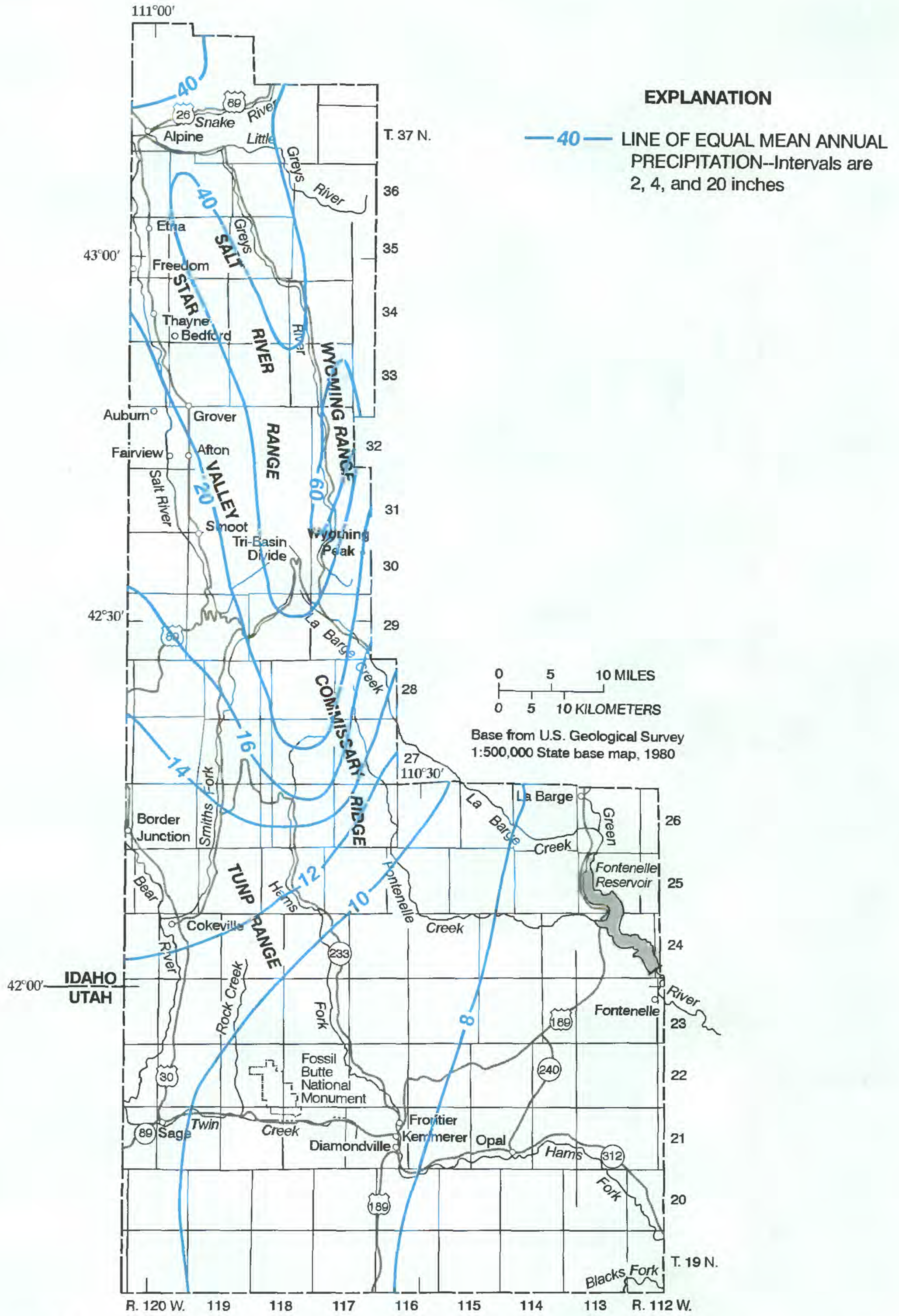

Figure 2. Mean annual precipitation for Lincoln County, Wyoming, 1951-80 (modified from Martner, 1986, fig. 6.1). 


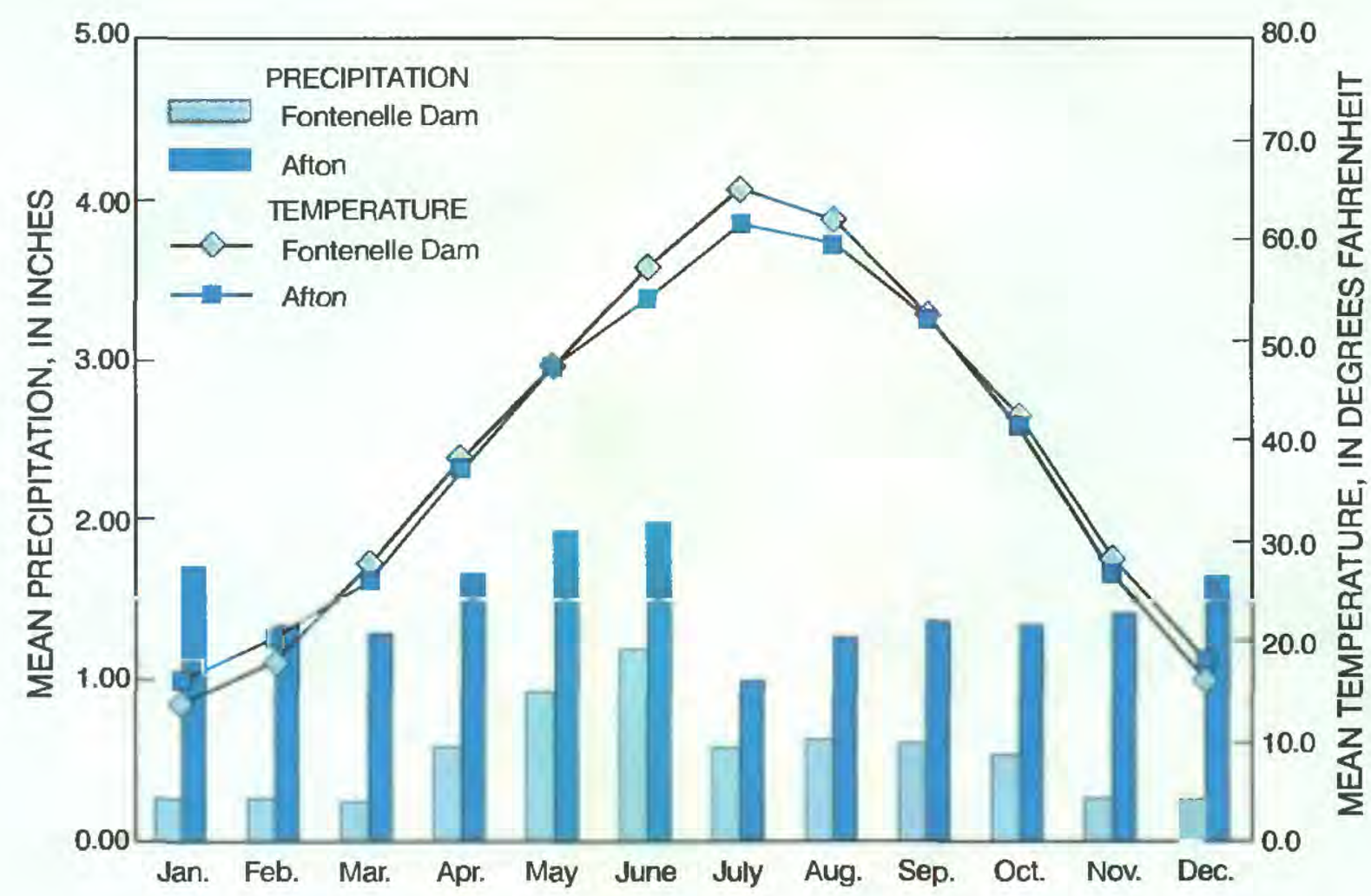

Figure 3. Mean monthly precipitation and air temperatures at Fontenelle Dam (1963-80) and town of Afton (1951-80), Lincoln County, Wyoming (data from Martner, 1986).

are formed on land rather than in the sea and may include sediments of lake, swamp, wind, stream, or volcanic origin. Mesozoic rocks in the county include limestone, siltstone, sandstone, coal, conglomerate, mudstone, and shale. Deposition and erosion of continental sediments has prevailed since the last marine regression during the Upper Cretaceous (Berry, 1955, p. 5). Tertiary rocks generally include intertonguing sandstones, siltstones, mudstones, and conglomerates deposited in fluvial (stream/river) and lacustrine (lake) environments. Unconsolidated Quaternary deposits include terrace gravels, graded fluvial sands and gravels, dune sand and loess, landslide, glacial, fan, and alluvial and colluvial deposits.

Thrust faulting, an overriding movement of one crustal unit over another, began in the western part of the Overthrust Belt during the Late Jurassic, continued during the Laramide orogeny, and ended in the early Eocene (Lines and Glass, 1975, sheet 1). In the Overthrust Belt, Paleozoic and Mesozoic rocks were thrust eastward and folded by a series of low-angle, westward-dipping thrust faults (Ahern and others, 1981, p. 26). The main geologic structural features of the Green River Basin were formed during the Laramide orogeny that extended from the Late Cretaceous into late Eocene time. The Laramide orogeny was not a single, long-term mountain building event, but rather a combination of intermittent tectonic activities that included uplifts, thrust faulting, local folding and normal faulting, and basin subsidence (Roehler, 1992, p. A2). The end of basin subsidence in the Green River Basin marked the end of the Laramide orogeny in the late Eocene (Roehler, 1992, p. A2). Tectonic activity has continued in the Overthrust Belt since the Laramide orogeny as indicated by faulted fan deposits (Lines and Glass, 1975, sheet 1). More recently, a series of earthquakes occurred in 1994 in the western part of Star Valley that ranged in magnitude from 4.3 to 5.9 on the Richter scale (Gary Glass, Wyoming State Geological Survey, written commun., 1994).

Mountains in the Overthrust Belt are bounded on the east by thrust faults and on the west by high-angle normal or reverse faults. Fossil Basin is a small structural basin in the southern part of the Overthrust Belt in Lincoln County. The eastern boundary of the basin is formed by Oyster Ridge, a north-south trending hogback ridge formed by resistent, west-dipping sandstone beds of Upper Cretaceous age (Roehler, 1992, p. A4) (pl. 3). The ridge formed a topographic barrier separating Fossil Basin and the Green River Basin during the deposition 
of some Tertiary rocks (Oriel and Tracey, 1970, p. 5). Star Valley, in the northwestern part of Lincoln County, is an elongate, northwest-trending intermontane valley. The valley is divided into two sections by a constriction called the Narrows that separates the southern part of Star Valley from the northern part of Star Valley (pl. 3). The valley is bounded to the east by the abrupt uplift of the Salt River Range along the Star Valley Fault and to the west and south by rolling uplands of Paleozoic and Mesozoic rocks called the Gannett Hills (Walker, 1965, p. C3) (pl. 3). Unconsolidated Quaternary fan deposits, built by erosion of the flanking mountains, and alluvium and colluvium occur on the valley floor.

The Darby Thrust Fault is the western geologic boundary of the Green River Basin. Relatively undisturbed Paleozoic and Mesozoic rocks in the Green River Basin are deeply buried beneath Tertiary and Quaternary deposits compared to the folded and faulted Paleozoic and Mesozoic rocks in the Overthrust Belt. The main structural feature within the Green River Basin part of the county is the Moxa Arch (pl. 3), a lowrelief, south plunging anticline (Lickus and Law, 1988). The southeastern sector of the study area occupies part of the western limb of the Moxa Arch. During the Paleocene and Eocene, the Green River Basin was occupied by ancient Lake Gosiute. The intertonguing of the Bridger, Green River, and Wasatch Formations is the result of areal water-level fluctuations of Lake Gosiute coupled with regional tectonic activity (Ahern and others, 1981, p. 21). About 10,000 feet of sediments accumulated as a result of various depositional processes operating in and surrounding the Basin during the Tertiary (Ahern and others, 1981).

\section{Water-Right Administration}

\section{By Richard G. Stockdale, Wyoming State Engineer's Office}

According to Article 8, Section 1 of the Wyoming State constitution, "The water of all natural streams, springs, lakes or other collections of still water, within the boundaries of the state, are hereby declared to be property of the state." Anyone desiring to use water beneficially in Wyoming must apply for and obtain an approved permit from the State Engineer to appropriate water prior to initiating construction of water-diversion structures, such as dams, headgates, spring boxes, and wells. Once a permit to appropriate water has been obtained from the State Engineer, the permittee may proceed with construction of the water-diversion works and with beneficial use of the diverted water for the purposes specified in the permit. Such diversion and beneficial use need to be made in accordance with statutory provisions. After the permittee has beneficially used the diverted water for all of the permitted uses at all of the permitted point(s) or area(s) of use, proof of beneficial use is filed, and the water right is adjudicated (finalized). The adjudication process fixes the location of the water-diversion structure, the use, the quantity, and the points or areas of use for the water right.

Wyoming water rights are administered using the Doctrine of Prior Appropriation, commonly referred to as the "First in time, first in right" system. Article 8, Section 3 of the Wyoming constitution states: "Priority of appropriation for beneficial uses shall give the better right." The priority date of an appropriation is established as the date when the application for permit to appropriate water is received in the State Engineer's Office.

Water-right administration is conducted by the State Engineer and four Water Division Superintendents. Article 8, Section 5 of the Wyoming constitution provides for the appointment of a State Engineer, and Section 4 provides for the creation of four Water Divisions in the State and the appointment of a superintendent in each division. The State Engineer is Wyoming's chief water-administration official and has general supervision of all waters of the State. The superintendents, along with their staff of hydrographers and water commissioners, are responsible for the local administration of water rights and the collection of hydrologic data in their respective divisions. 
Deviations from the standard water-right administrative system of "First in time, first in right" might exist. Such deviations might be caused by conditions in compacts, court decrees, and treaties or through the creation of special water-management districts. Virtually every stream exiting the State is subject to a compact, court decree, or treaty that dictates to some degree how the appropriations on that specific stream are administered. Although the interstate nature of ground water and the interconnection of ground water with streams are recognized, the development of interstate agreements on use of water from aquifers is still in its infancy. The reason that few ground-water compacts exist is twofold. First, there is a lack of sound technical data on which to base appropriate administrative allocations of ground water between adjoining States, and second, there is not sufficient competition between Wyoming and adjoining States to require binding interstate agreements or allocations of ground-water resources.

\section{Acknowledgments}

The authors gratefully acknowledge the cooperation and assistance of farmers, ranchers, landowners, and drillers of Lincoln County. Individuals from the Star Valley Conservation District provided invaluable assistance with locating monitoring wells within the valley. The help and orientation from Ken Mills of the Natural Resources Conservation Service was greatly appreciated. John P. R. Holland II, Julie A. Whalen, Kirk A. Miller, Pamela M. Hann, and Joel M. Galloway of the U.S. Geological Survey are recognized for exceptional help with data collection.

\section{STREAMFLOW}

The headwaters of tributaries to three major drainage basins originate in Lincoln County: the Green River, the Bear River, and the Snake River Basins (Lines and Glass, 1975, sheet 3; Schuetz and others, 1995, p. 2). Major tributaries to the Green River include La Barge Creek and Hams Fork. The major tributary to the Bear River is Smiths Fork. Major tributaries to the Snake River include the Salt River and the Greys River. The geographic location where all three basins meet is the Tri-Basin Divide, located approximately 14 miles southeast of Smoot on National Forest land (fig. 1).

\section{Streamflow Data}

Streamflow data are needed when planning, designing, or managing water use and development associated with streams. To obtain these data, streamflow-gaging or sampling stations are installed and operated on the principal streams. At these stations, data are collected continuously or periodically. Streamflow-gaging and sampling stations are operated for a variety of purposes in the county; a primary purpose is for planning and managing irrigation-water supplies.

Streamflow data generally are collected at continuous-record streamflow gaging stations, where water-level sensing equipment and a recorder are housed in a streamside shelter. Using discharge measurements of the streamflow, hydrographers develop a relation known as a rating between stage (water level) and measured discharge at the gaging station (fig. 4). This rating is used with the continuous record of stage from the gagingstation recorder to develop a continuous record of stream discharge. The locations of 61 gaging stations where substantial amounts of data have been collected for streamflow and water quality in the county are shown on plate 2, and specific information concerning these stations is listed in table 1. Records for some stations listed in this table may have been published previously using a slightly different station name. Previously published names are included in the station manuscript of the U.S. Geological Survey (USGS) Water Resources Data report for Wyoming, which is published annually. 
Select measurement site
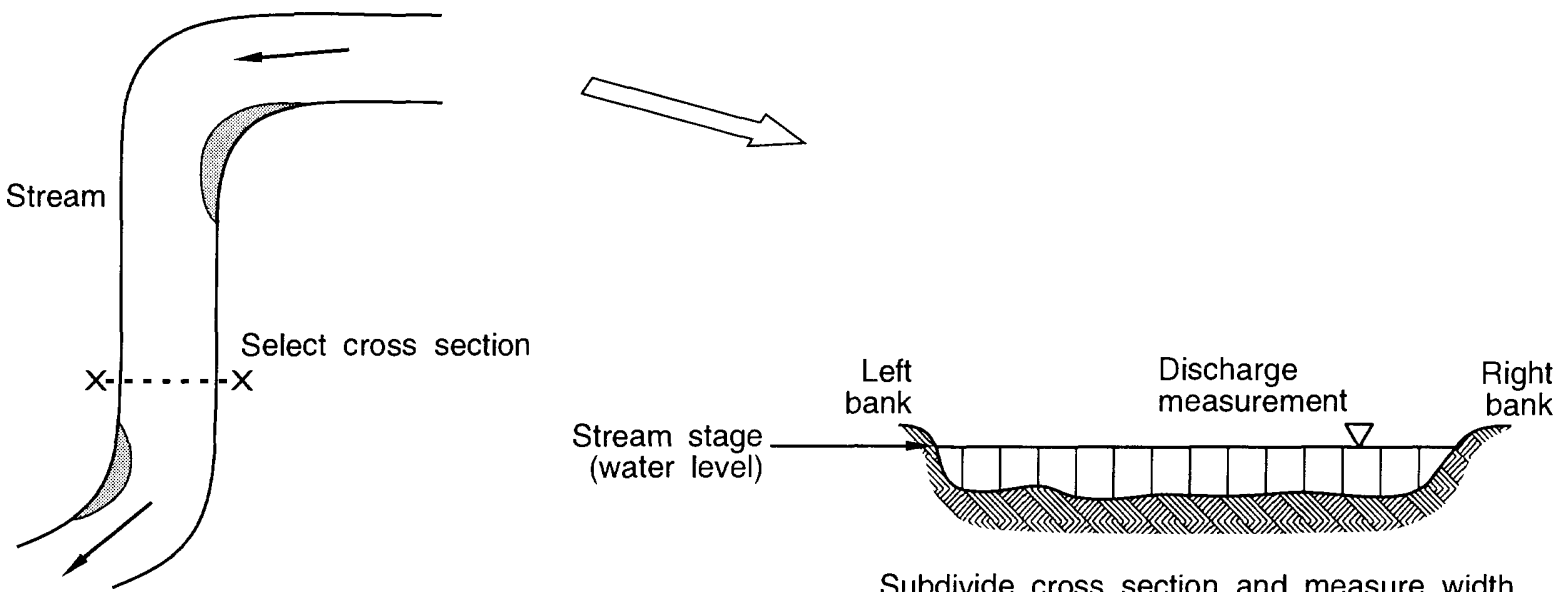

Subdivide cross section and measure width, depth, and mean velocity of each subsection. Multiply width, depth, and velocity to obtain discharge for each subsection. Sum increments to determine total discharge of stream.

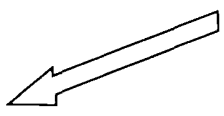

Stage-discharge rating

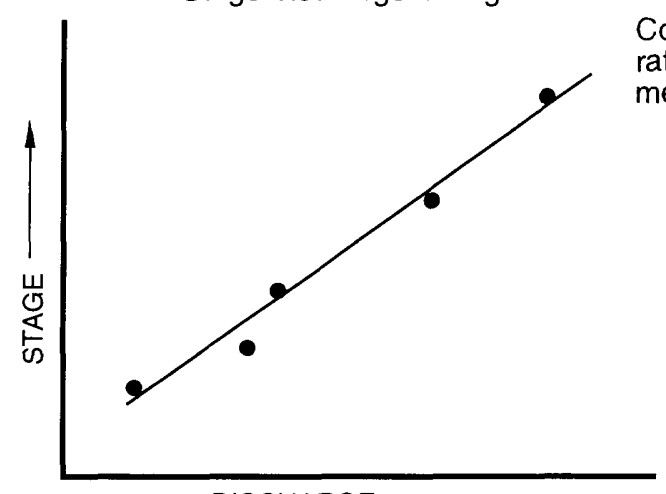

Construct stage-discharge

rating from discharges

measured at various stages.

DISCHARGE

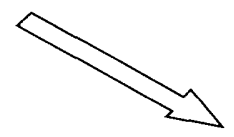

Collect continuous record of stage at gaging station. Combine rating with stage record to yield discharge record.

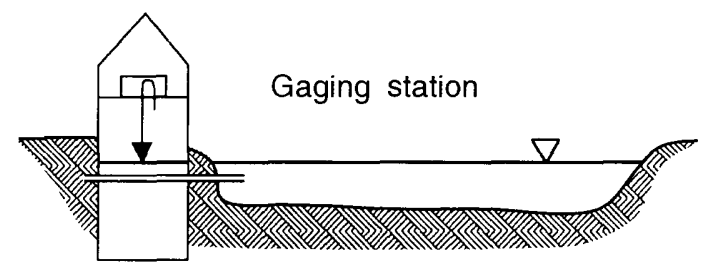

Figure 4. Procedure for collection of streamflow data at a gaging station (from Lowham, 1988, p.13). 


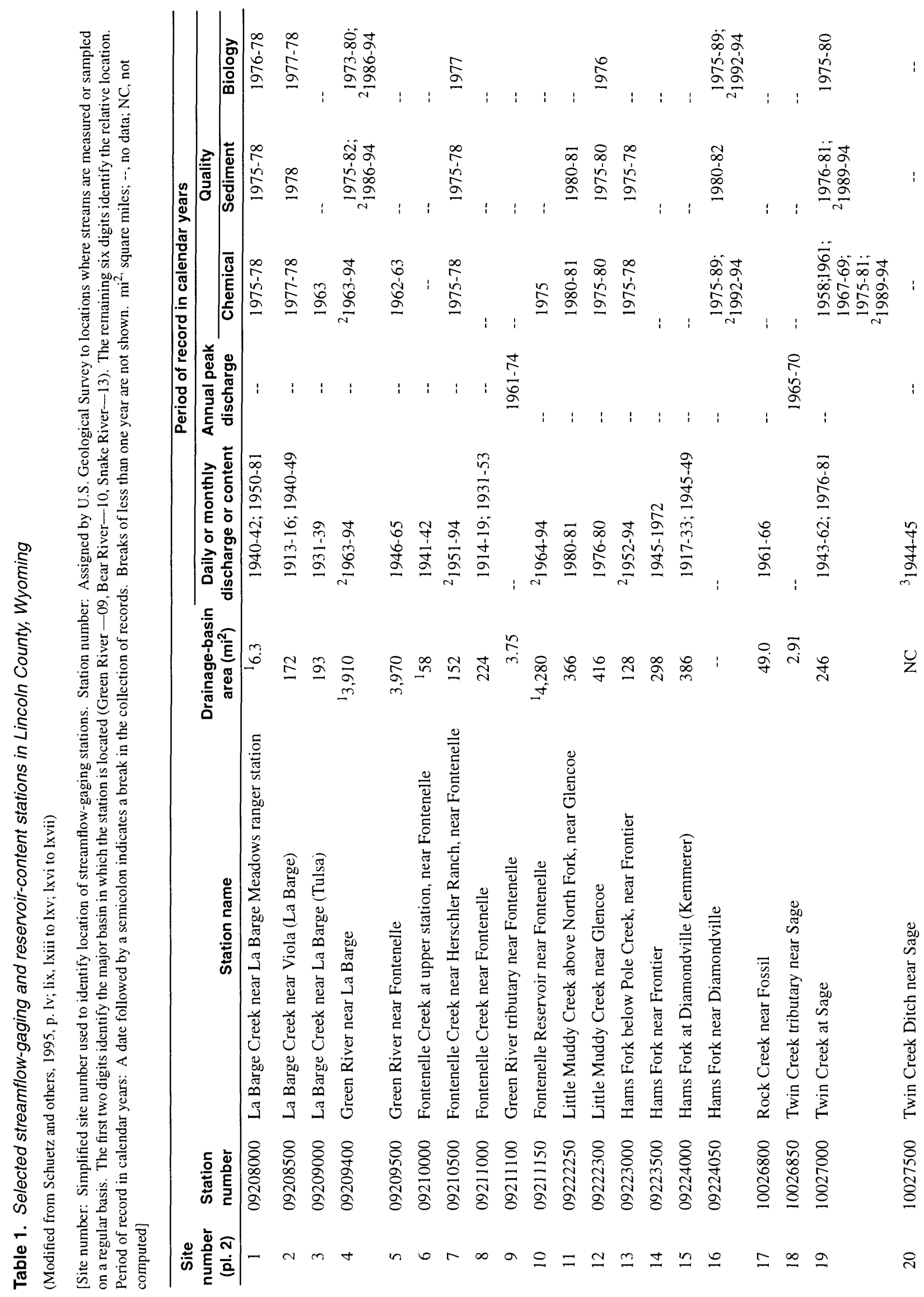




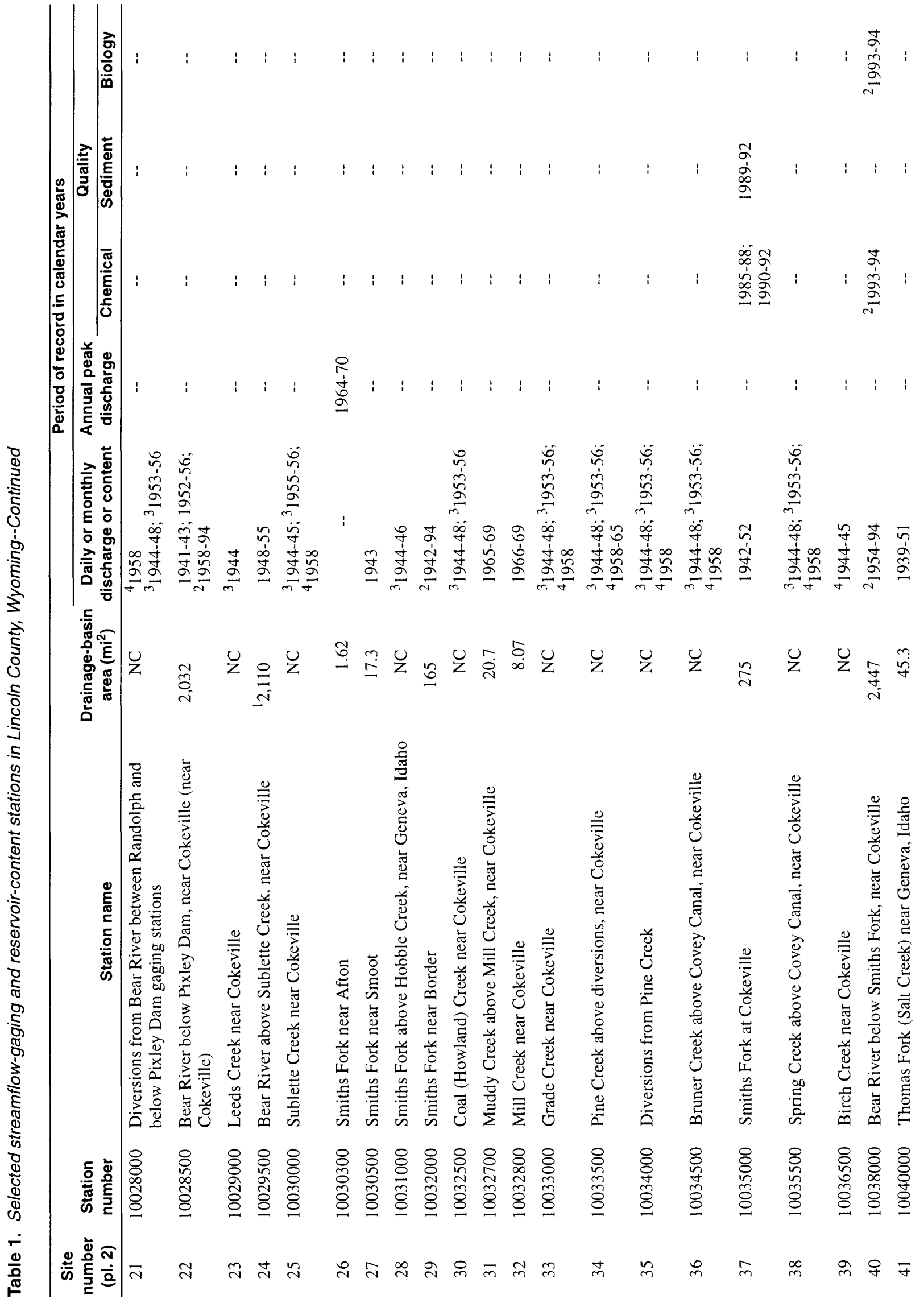




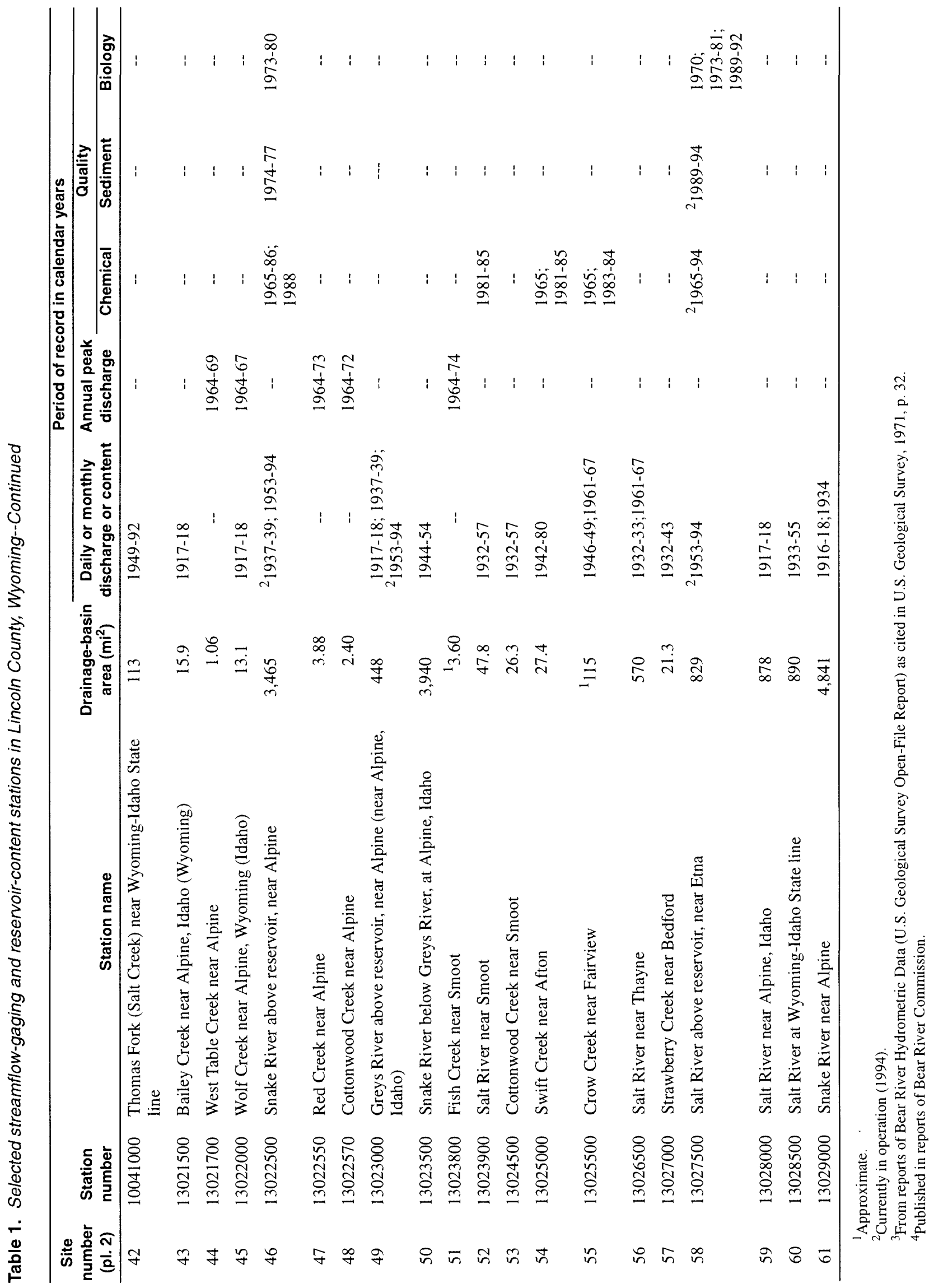


Streamflow and water-quality data are sometimes required locally where streamflow-gaging or sampling stations are not operated. For example, determination of water loss or gain from seepage in a particular stream reach may require measurements of discharge at several locations along the stream reach. Likewise, definition of water-quality changes within a stream reach may require that water samples be collected (periodically or routinely) at several locations to account for the effects of inflows from seeps and tributaries. Locations where measurements or samples were collected infrequently are defined as miscellaneous streamflow sites. Locations of 52 miscellaneous streamflow sites used for this study are shown on plate 2 , and specific information concerning these sites is listed in table 2.

Additional information about streamflow-gaging stations and miscellaneous streamflow sites in the county can be obtained from computer files and published reports of the USGS. Inquiries can be directed to the District Chief, U.S. Geological Survey, 2617 E. Lincolnway, Suite B, Cheyenne, Wyoming 82001-5662.

\section{Streamflow Characteristics}

Streams in Lincoln County can be classified as ephemeral, intermittent, or perennial. Assigning a stream type can be somewhat arbitrary because the process depends on which reach of the stream is being considered and the length of time the stream has been observed (Lowham, 1985, p. 32).

Streams that primarily drain desert areas of the county are usually ephemeral or intermittent. Ephemeral and intermittent streams only flow periodically in response to direct surface runoff and often have extended periods of no flow (Lowham, 1988, p. 5). The two stream types differ slightly, as intermittent streams may receive some ground-water inflow in addition to direct surface runoff; however, ground-water inflow is insufficient to sustain flow throughout the year (Lowham, 1985, p. 32). For the purpose of this report, ephemeral and intermittent stream types will be classified as one type: ephemeral/intermittent. A hydrograph for Pacific Creek near Farson (located 40 miles east of Fontenelle in Sweetwater County) illustrates the streamflow of an ephemeral/intermittent stream (fig. 5).

Most perennial streams originate in the mountainous areas of the county. Streamflow in these areas occurs mainly as a result of snowmelt runoff (Lowham, 1988, p. 5). Water stored as ground water in the mountains is released slowly, maintaining streamflow throughout the year. An example of a perennial stream is Hams Fork below Pole Creek near Frontier (site 13); a hydrograph for this streamflow-gaging station is shown in figure 5. The hydrograph shows the characteristic period of snowmelt runoff from April through July followed by sustained flow throughout the year.

The continuous record of stream discharge, described in the "Streamflow Data" section, can be summarized statistically to express streamflow characteristics, such as, average daily, monthly, or yearly rates or volumes of discharge. Instantaneous peak flow and total runoff for a particular period also can be determined from the records. Streamflow characteristics at 21 selected streamflow-gaging stations in the county are listed in table 3 and include: average annual flow, average annual runoff, and annual peak flow for selected recurrence intervals. Additional streamflow characteristics can be found in Peterson (1988, p. 52-61; p. 102-109; p. 178185; p. 188-193, and p. 208-221).

Estimates of streamflow characteristics at sites with no streamflow-gaging stations can be made using equations "that relate streamflow characteristics to features of the drainage basin" (Lowham, 1988, p. 16). Factors affecting streamflow are climate, topography, and geology. Wyoming's terrain is diverse, and because these factors vary with terrain, Lowham (1988, p. 18) identified three distinct hydrologic regions in the State and developed different equations to estimate streamflow characteristics in each region. The three hydrologic regions are Mountainous, High Desert, and Plains. The region boundaries were defined by the use of colorinfrared imagery and known streamflow characteristics. Most of Lincoln County is within the Mountainous Region. The southeastern and southwestern parts of the county are located in the High Desert Region: the Plains Region is not present in Lincoln County. 


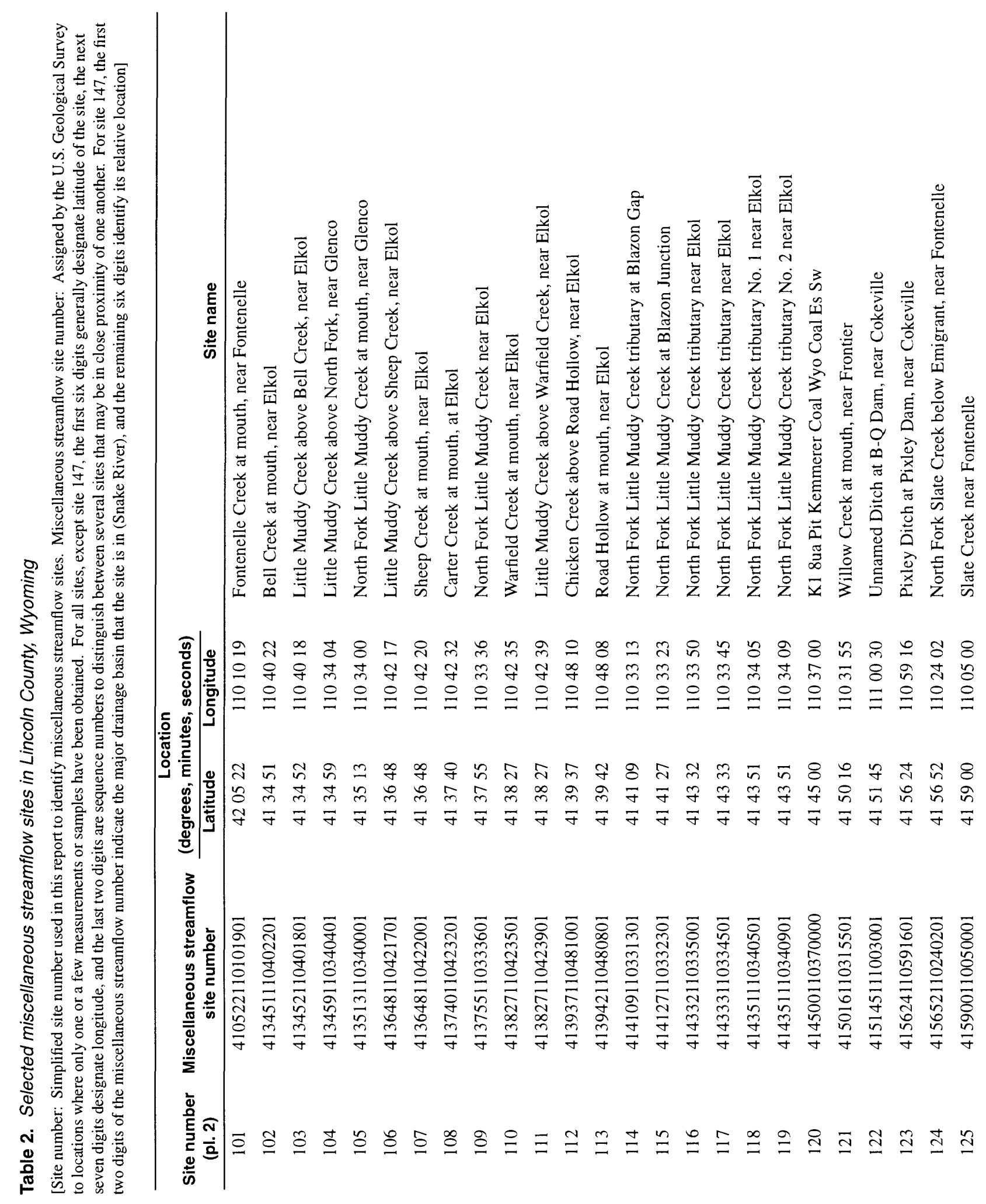




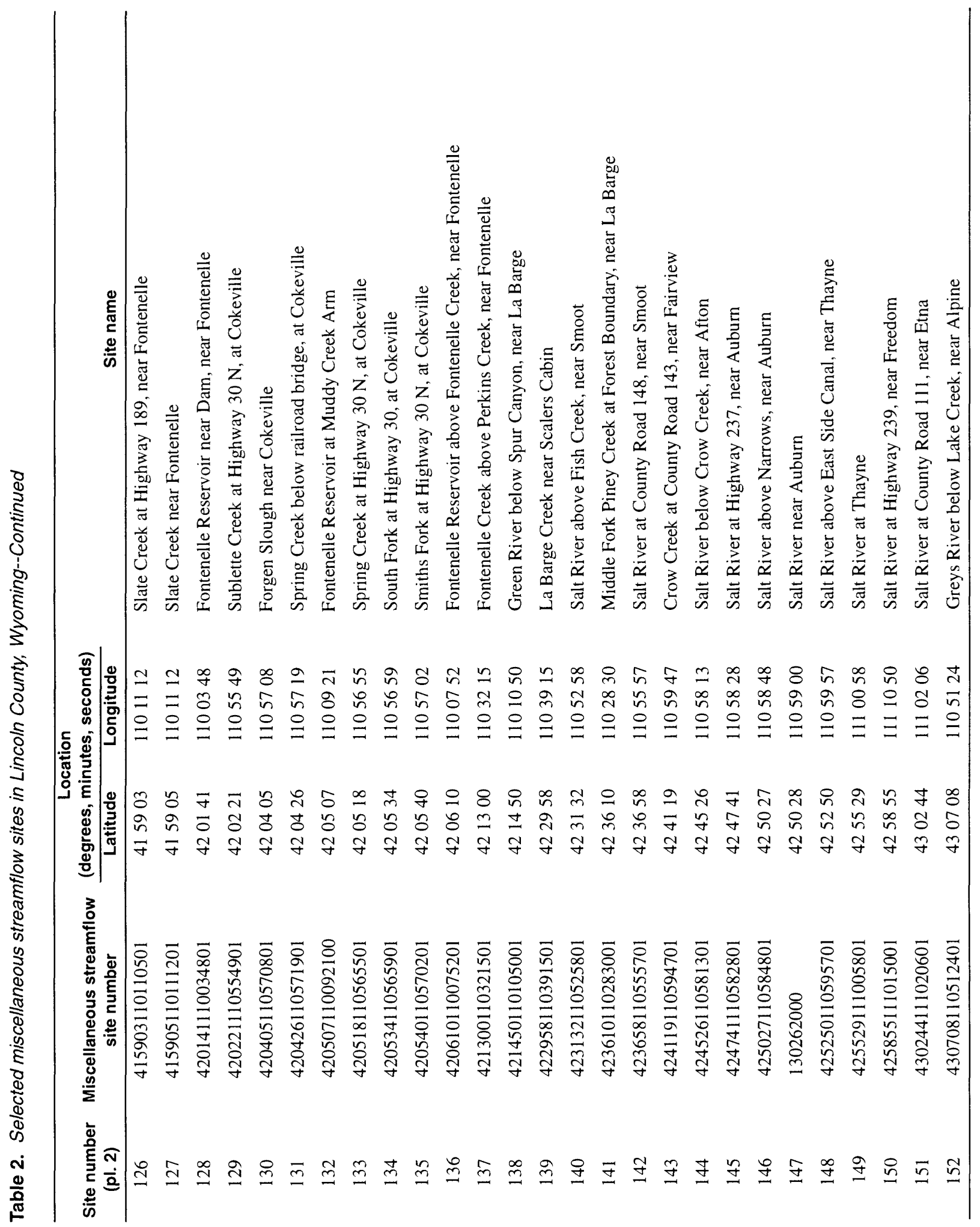




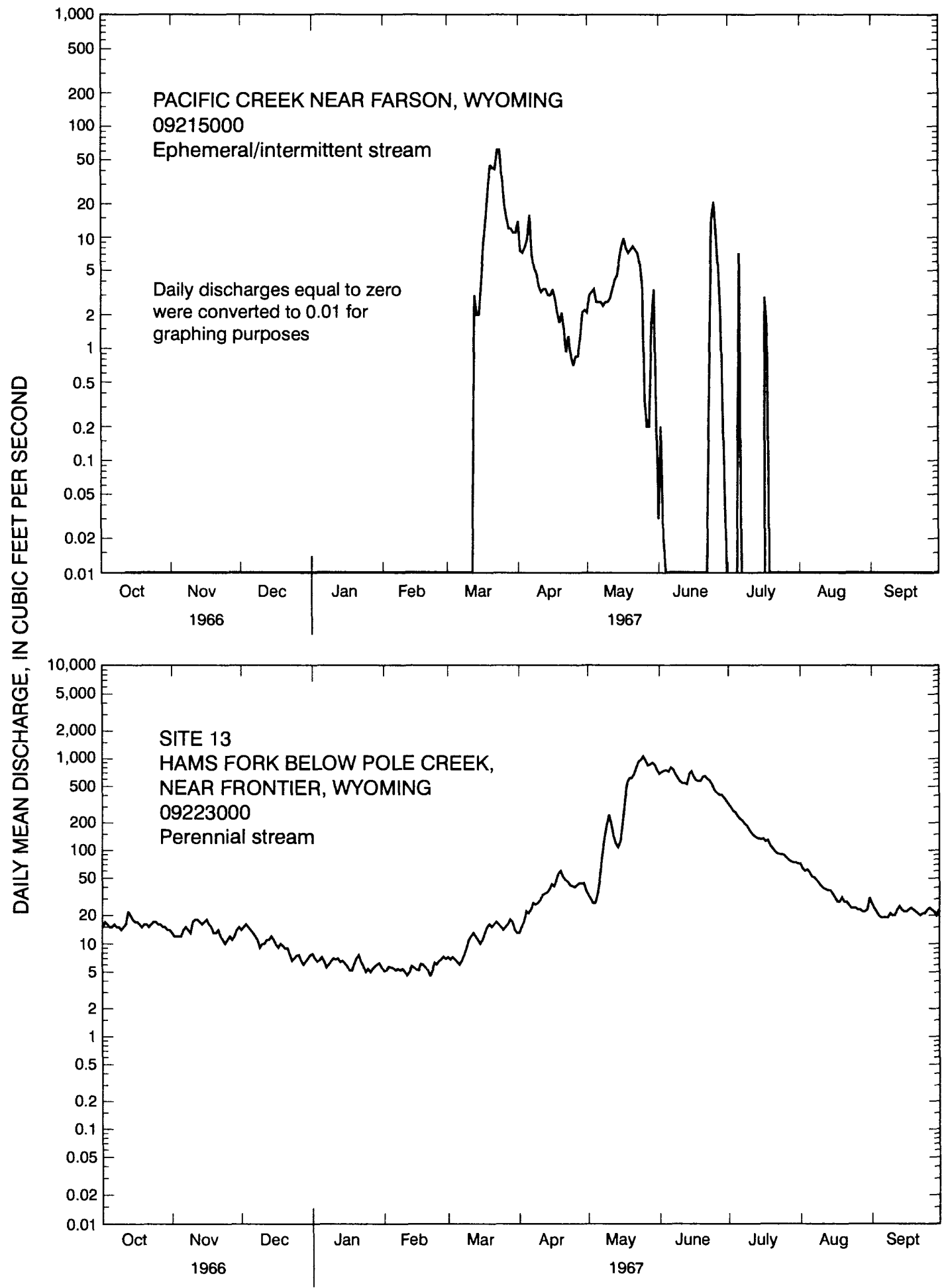

Figure 5. Daily mean discharge for an ephemeral/intermittent stream and a perennial stream, water year 1967. 


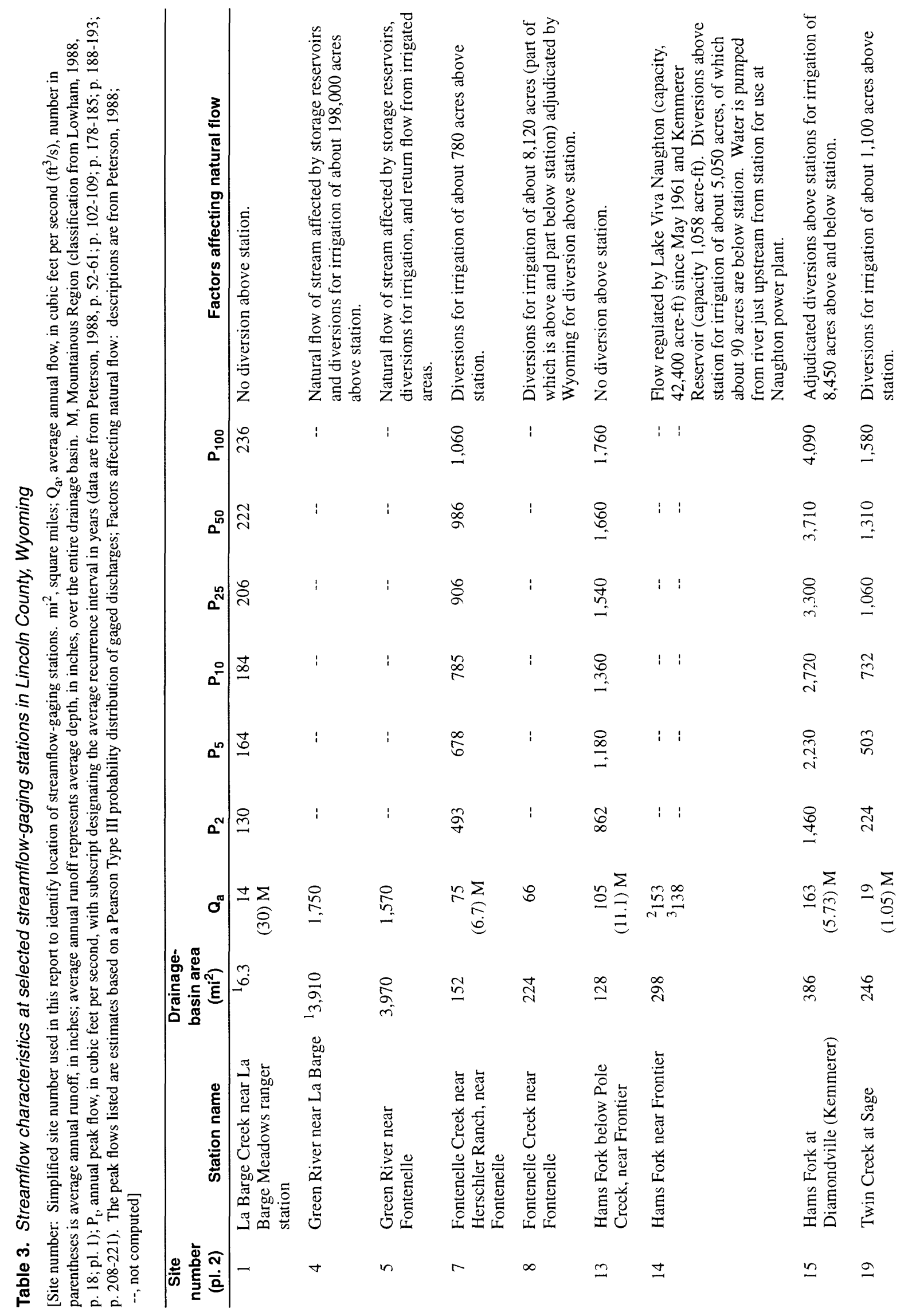




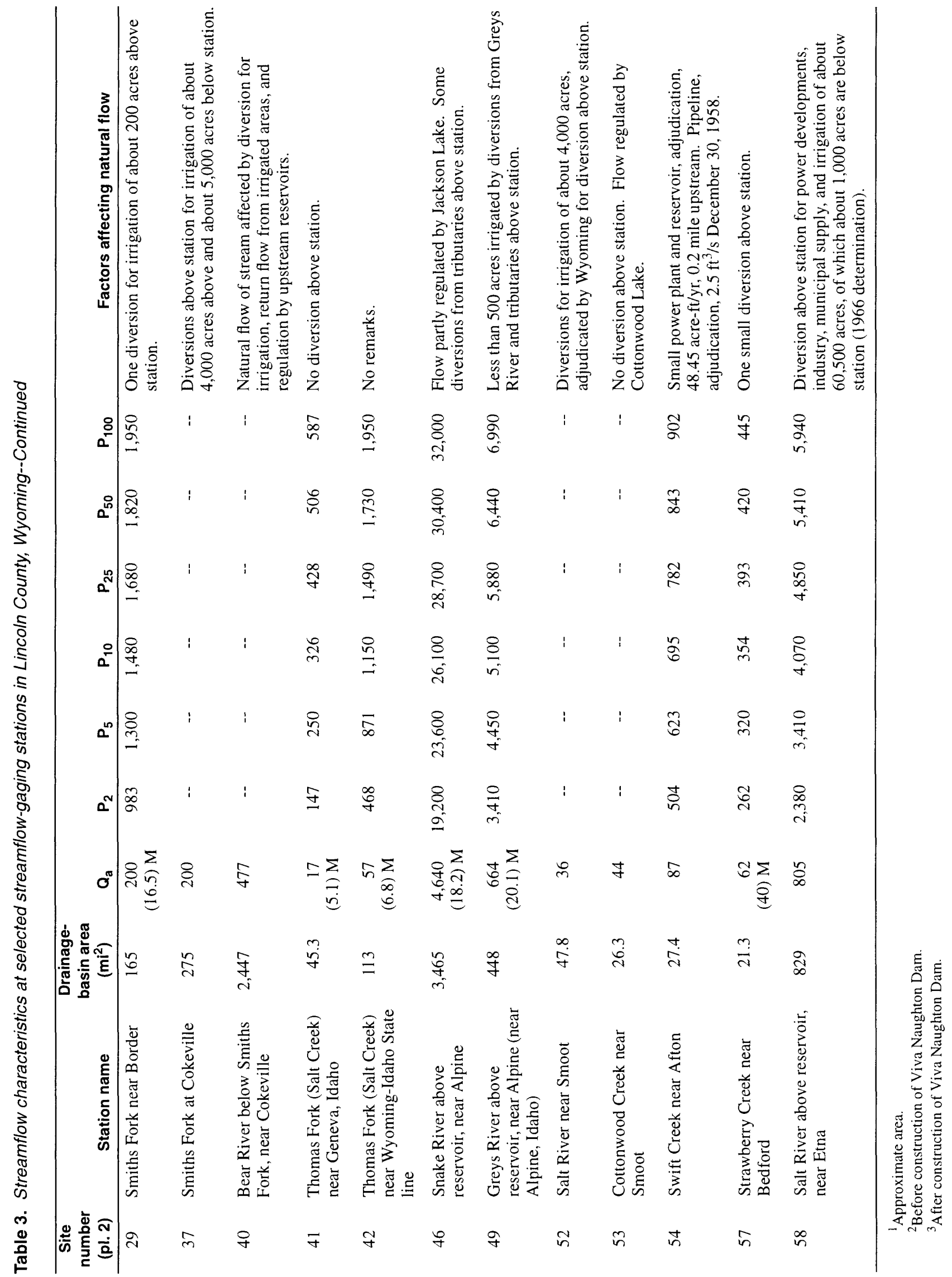




\section{Average Annual Runoff}

Average annual flow $\left(Q_{a}\right)$ is a measure of streamflow past a reference point. Average annual runoff distributes the annual flow across the drainage basin and is a useful estimate of how much water a watershed/ drainage basin will produce. Average annual runoff typically is computed for selected streamflow-gaging stations that have a minimum period of record of 5 years and that monitor streamflow that has not been substantially affected by artificial diversions, storage, or human activities in or on the stream channels (table 3). The streamflow characteristics in table 3 were computed using " 10 or more complete years of record (Peterson, 1988, p. 10)." Fewer than one-fourth ( 4 of 21) of the stations in table 3 are not affected by some sort of diversion.

Average annual runoff from drainage areas in the Mountainous Region of Lincoln County is a function of climatic variables, topography, geology, and the size of the drainage basins. Important climatic variables are precipitation, temperature, wind, evaporation, and solar radiation. Climatic conditions of an intermontane drainage basin are related to the basin altitude and the topographic position of the basin in relation to the mountain ranges. Drainage-basin size is the most important physical characteristic. Water storage in lakes, ponds, and aquifers has some effect on total runoff, but to a lesser degree than the climatic conditions and drainage-basin size (Rankl, 1987, p. 30).

Surface-water runoff in Lincoln County is mainly from the Mountainous Region in the northern and central parts of the county. The average annual runoff for 11 streamflow-gaging stations recording runoff mostly from this region ranged from 1.05 to $40 \mathrm{in} / \mathrm{yr}$ (table 3 ). The runoff measured at these gaging stations originates in the Salt River, Tunp, and Wyoming Ranges.

Average annual runoff of streams originating in the High Desert Region in the southeastern and southwestern parts of Lincoln County is a function of quantity and intensity of precipitation, drainage-basin area, evapotranspiration, and infiltration rate of water into surficial material. Rainstorm intensities or snowmelt rates exceeding the infiltration rate of moisture into the surficial material produce runoff. Irrigation storage, drainage structures, and stock ponds decrease the total runoff from a drainage basin because they divert water for consumptive uses and increase evapotranspiration (Rankl, 1987, p. 30).

None of the streams with streamflow-gaging stations listed in table 3 were described by Lowham (1988) as receiving most of their flow from the High Desert Region. This type of stream, however, does exist in the county. The gaging station on Pacific Creek near Farson (located 40 miles east of Fontenelle in Sweetwater County) is used as a representative station in the High Desert Region. Pacific Creek originates in the High Desert Region and has an average annual runoff of $0.1 \mathrm{in} / \mathrm{yr}$ at the gaging station near Farson. The flow at this station, however, is affected by diversions for irrigation, imported water from the Sweetwater River Basin, and an upstream reservoir, Pacific No. 2.

\section{Flow Duration}

Streamflow is the result of variable precipitation and the drainage-basin characteristics. Streamflow duration is dependent on the following drainage-basin characteristics: climate, physiography, geology, and land use. Drainage basins where these characteristics are similar can have flow-duration curves similar in shape. High flow is controlled mainly by climate, physiography, and land use in the basin. Low flow is controlled mainly by the geology of the basin, as the flow is sustained primarily from ground water. The effects of precipitation on streamflow are reduced by storage, either on the surface or in the ground (Searcy, 1959, p. 30). 
The flow-duration curve is a cumulative frequency curve of daily mean discharges showing the percentage of time that specified discharges were equalled or exceeded during a period of record. This curve does not account for the chronological sequence of hydrologic events, but combines the flow characteristics of a stream throughout its range of discharge. Flow-duration characteristics presented here and the methods used to develop the curves are from Peterson $(1988$, p. 2). The flow-duration curve applies only to the period of record for which the curve was developed. Streamflow data for complete years of record were used for the flowduration curves. Although the years need not be consecutive, the records used represent periods when human activities such as reservoir storage and irrigation diversions remain unchanged.

Flow-duration curves can be used to evaluate the variability of streamflow in the county. To illustrate the variability, flow-duration curves were developed for selected streamflow-gaging stations representing each stream type (fig. 6). Hams Fork below Pole Creek, near Frontier, (site 13) is located in the Mountainous Region in the south-central part of the county. The flow-duration curve for site 13 indicates high streamflows (greater than 50 cubic feet per second $\left(\mathrm{ft}^{3} / \mathrm{s}\right)$ ) are sustained primarily by snowmelt. Sustained baseflow in the low-flow range indicates ground-water inflow and characterizes storage in the basin.

Pacific Creek near Farson is located in the High Desert Region in Sweetwater County. The flow-duration curve for this site indicates variable streamflow that is dependent primarily on direct surface runoff. During the period 1955-73, daily mean discharge at Pacific Creek near Farson equalled or exceeded $19 \mathrm{ft}^{3} / \mathrm{s}$ only 5 percent of the time (fig. 6).

The flow-duration curve for each site in figure 6 applies only to the period for which the curve was developed. For each site, all available records were used. Extended high flows of a wet year (or extended low flows of a dry year) tend to skew the curve on the high-flow (or low-flow) end, and care is needed when such curves are applied to specific years. The converse also is true, because curves representing a short period of record do not necessarily represent long-term flow characteristics.

\section{Low Flow}

Frequency analysis of low-flow data provides information about water-supply conditions related to municipal, industrial, and irrigation uses, instream fisheries, and waste disposal. Indices generally used to describe low-flow characteristics of streams are the lowest mean discharges averaged over 7 consecutive days and having recurrence intervals of 2 and 10 years. For simplicity, these indices are referred to as the 7-day $Q_{2}$ $\left(7 \mathrm{Q}_{2}\right)$ and 7-day $\mathrm{Q}_{10}\left(7 \mathrm{Q}_{10}\right)$ discharges. In any given year, there is a 50-percent chance that the flow will not exceed the $7 \mathrm{Q}_{2}$ for 7 consecutive days (10-percent chance for the $7 \mathrm{Q}_{10}$ ).

Seven-day low-flow discharges for 21 selected streams are listed in table 4 . The $7 \mathrm{Q}_{2}$ and $7 \mathrm{Q}_{10}$ discharges per square mile (yields) also are listed in table 4 for comparison purposes. However, note that the $7 Q_{2}$ and $7 Q_{10}$ discharges in table 4 cannot be extrapolated to other reaches on the same stream or to other streams in the drainage basin without knowledge of the drainage-basin characteristics and without knowledge of the effects of human activities. Low-flow frequency values for the various stations cannot be directly compared because the values are based on different periods of record. For this table, records for Hams Fork near Frontier (site 14) were divided into periods prior to and following the construction of Viva Naughton Dam on the Hams Fork.

The hydrographs in figure 5 illustrate the differences in the occurrence of low flow between ephemeral/ intermittent and perennial streams. In ephemeral/intermittent streams, low flow is zero flow, because many of these streams are dry most of the year. Low flows in perennial streams occur in the winter (normally October through March) and are predominantly from ground-water inflows. 


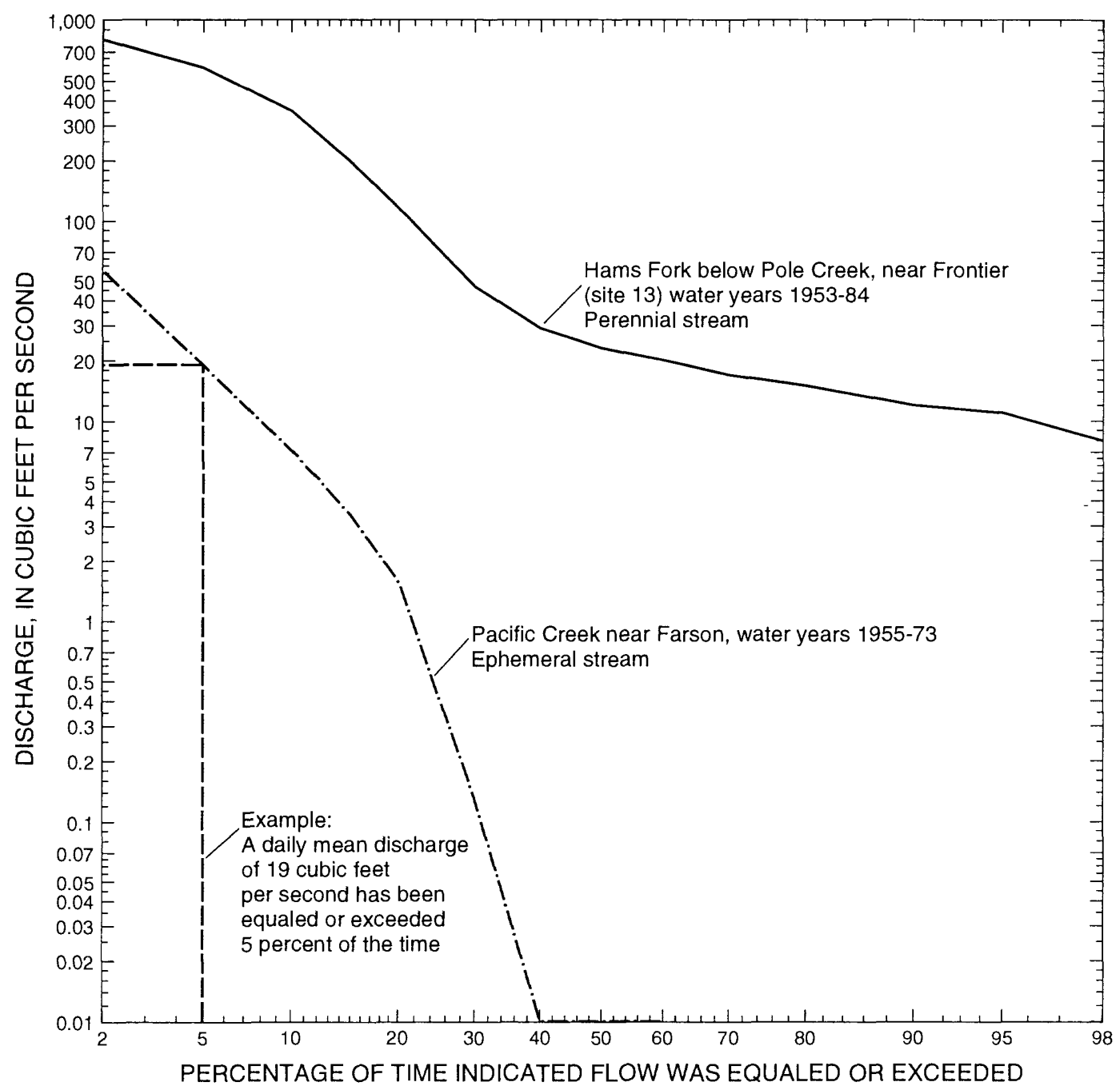

Figure 6. Flow-duration curves of daily mean discharge for Hams Fork below Pole Creek near Frontier, Lincoln County, Wyoming, and Pacific Creek near Farson, Sweetwater County, Wyoming. 
Table 4. Seven-day low-flow discharges for selected streamflow-gaging stations in Lincoln County, Wyoming

[Site number: Simplified site number used in this report to identify location of streamflow-gaging stations; $\mathrm{mi}^{2}$, square miles; $\mathrm{ft}^{3} / \mathrm{s}$, cubic feet per second; $\left(\mathrm{ft}^{3} / \mathrm{s}\right) / \mathrm{mi}^{2}$, cubic feet per second per square mile of drainage-basin area]

\begin{tabular}{|c|c|c|c|c|c|c|c|}
\hline \multirow{3}{*}{$\begin{array}{c}\text { Site } \\
\text { number } \\
\text { (pl. 2) }\end{array}$} & \multirow[b]{3}{*}{ Station name } & \multirow{3}{*}{$\begin{array}{c}\text { Drainage- } \\
\text { basin } \\
\text { area } \\
\left(\mathrm{mi}^{2}\right)\end{array}$} & \multirow{3}{*}{$\begin{array}{l}\text { Length of } \\
\text { record } \\
\text { (years) }\end{array}$} & \multicolumn{4}{|c|}{$\begin{array}{l}\text { Seven-day low-flow discharge for indicated } \\
\text { recurrence interval }\end{array}$} \\
\hline & & & & \multicolumn{2}{|c|}{2 years } & \multicolumn{2}{|c|}{10 years } \\
\hline & & & & $\begin{array}{c}\text { Discharge } \\
\left(\mathrm{ft}^{3} / \mathrm{s}\right)\end{array}$ & $\begin{array}{c}\text { Yield } \\
{\left[\left(\mathrm{ft}^{3} / \mathrm{s}\right) / \mathrm{mi}^{2}\right]}\end{array}$ & $\begin{array}{c}\text { Discharge } \\
\left(\mathrm{ft}^{3} / \mathrm{s}\right)\end{array}$ & $\begin{array}{c}\text { Yield } \\
{\left[\left(\mathrm{ft}^{3} / \mathrm{s}\right) / \mathrm{mi}^{2}\right]}\end{array}$ \\
\hline 1 & $\begin{array}{l}\text { La Barge Creek near La Barge Meadows } \\
\text { ranger station }\end{array}$ & ${ }^{1} 6.3$ & 30 & 3.1 & 0.49 & 2.2 & 0.35 \\
\hline 4 & Green River near La Barge & $1_{3,910}$ & 20 & 406 & .104 & 293 & .0749 \\
\hline 5 & Green River near Fontenelle & 3,970 & 18 & 316 & .0796 & 238 & .0599 \\
\hline 7 & $\begin{array}{l}\text { Fontenelle Creek near Herschler Ranch, } \\
\text { near Fontenelle }\end{array}$ & 152 & 32 & 19 & .13 & 12 & .079 \\
\hline 8 & Fontenelle Creek near Fontenelle & 224 & 24 & 15 & .067 & 0 & 0 \\
\hline 13 & Hams Fork below Pole Creek, near Frontier & 128 & 31 & 12 & .094 & 4.5 & .035 \\
\hline 14 & Hams Fork near Frontier & 298 & $\begin{array}{l}214 \\
310\end{array}$ & $\begin{array}{l}11 \\
12\end{array}$ & $\begin{array}{l}.037 \\
.040\end{array}$ & $\begin{array}{l}5.7 \\
6.9\end{array}$ & $\begin{array}{l}.019 \\
.023\end{array}$ \\
\hline 15 & Hams Fork at Diamondville (Kemmerer) & 386 & 17 & 13 & 034 & 0 & 0 \\
\hline 19 & Twin Creek at Sage & 246 & 23 & 3.2 & .013 & 1.8 & .0073 \\
\hline 29 & Smiths Fork near Border & 165 & 41 & 56 & .34 & 50 & .30 \\
\hline 37 & Smiths Fork at Cokeville & 275 & 9 & 55 & .20 & 32 & .12 \\
\hline 40 & $\begin{array}{l}\text { Bear River below Smiths Fork, near } \\
\text { Cokeville }\end{array}$ & 2,447 & 28 & 129 & .0527 & 69 & .028 \\
\hline 41 & $\begin{array}{l}\text { Thomas Fork (Salt Creek) near Geneva, } \\
\text { Idaho }\end{array}$ & 45.3 & 11 & 2.6 & .057 & 1.7 & .038 \\
\hline 42 & $\begin{array}{l}\text { Thomas Fork (Salt Creek) near Wyoming- } \\
\text { Idaho State line }\end{array}$ & 113 & 34 & 12 & .11 & 7.9 & .070 \\
\hline 46 & Snake River above reservoir, near Alpine & 3,465 & 31 & 1,280 & .369 & 1,030 & .297 \\
\hline 49 & $\begin{array}{l}\text { Greys River above reservoir, near Alpine } \\
\text { (near Alpine, Idaho) }\end{array}$ & 448 & 32 & 176 & .393 & 145 & .324 \\
\hline 52 & Salt River near Smoot & 47.8 & 24 & 4.9 & .10 & 1.9 & .040 \\
\hline 53 & Cottonwood Creek near Smoot & 26.3 & 24 & 11 & .42 & 9.0 & .34 \\
\hline 54 & Swift Creek near Afton & 27.4 & 28 & 31 & 1.1 & 27 & .99 \\
\hline 57 & Strawberry Creek near Bedford & 21.3 & 10 & 28 & 1.3 & 25 & 1.2 \\
\hline 58 & Salt River above reservoir, near Etna & 829 & 30 & 387 & 467 & 301 & .363 \\
\hline
\end{tabular}

${ }^{1}$ Approximate area.

${ }^{2}$ Before construction of Viva Naughton Dam.

${ }^{3}$ After construction of Viva Naughton Dam. 


\section{High Flow}

High-flow characteristics of streams in Lincoln County vary with stream type. High flows in ephemeral/ intermittent streams are the result of lowland snowmelt or rainfall runoff during spring thaw or from summer thunderstorms. Snowmelt runoff usually is smaller in magnitude and longer in duration than rainfall runoff. Runoff from intense thunderstorms can be extremely large and of short duration. Magnitude and duration of rainfall runoff depend on drainage-basin characteristics and on the distribution and intensity of precipitation. Peak flow in most ephemeral/intermittent streams is reached quickly from rainfall runoff, and is followed by an equally rapid decrease in flow, with a gradual return to no-flow conditions. Because of these rapid changes in flow, the timing of streamflow measurements to include peak discharge on ephemeral/intermittent streams is difficult. Peak flows on ephemeral/intermittent streams usually are measured by indirect methods, as discussed in Benson and Dalrymple (1967). Perennial streams generally have a period of high flow in May and June as the melting of mountain snowpacks peaks.

Diurnal fluctuations in flow are typical during snowmelt periods with successive daily flows increasing as daylight hours lengthen and temperatures increase. This diurnal pattern, if uninterrupted by changing weather conditions, continues until peak flows occur. However, weather conditions have a substantial effect on snowmelt runoff, making peak flows difficult to predict.

The design of bridges and culverts for road crossings, dams, diversions, and other structures on or near streams requires information about expected peak-flow conditions (floods). If routine streamflow measurements have been made in the vicinity of a planned structure, statistical analysis of the annual maximum instantaneous flows for the period of record can be used to determine the magnitude and frequency of floods. If peak-flow records are not available, then an estimate generally is made using one of several other techniques that are available (Lowham, 1985, p. 34). For example, if a bridge, when built, was planned to be used for 20 or more years, the bridge was designed for the 100-year peak flow $\left(\mathrm{P}_{100}\right)$. The 100-year peak flow, or 100-year flood, for selected streamflow-gaging stations in the county is listed in table 3. A 100-year flood is defined as the annual maximum instantaneous (peak) discharge that will be equalled or exceeded once in 100 years, on the average. Alternately, the 100-year flood is the discharge that has a 1-percent chance of being equalled or exceeded during any particular year. Instantaneous peak flows with recurrence intervals of 2, 5, 10, 25, and 50 years are also listed in table 3. The magnitude of these flows is listed for stations where the natural flow is not substantially affected by regulation, diversion, or irrigation. The method used to compute the instantaneous peak flows listed in table 3 is described in Peterson (1988, p. 3).

Peak flow in ephemeral and intermittent streams result from precipitation occurring more in the form of widespread general rainstorms and snow and less in the form of convective storms (Lowham, 1988, p.18). Peak flows in the Mountainous Region are small in relation to peak flows in the High Desert Region, but annual runoff is larger in the Mountainous Region (Lowham, 1988, p. 18).

\section{GROUND WATER}

The quantity and quality of ground water in Lincoln County differs within and between geologic units and is controlled by the lithologic, structural, and geochemical properties of the rocks. Ground-water data in this report, including water levels, well or spring discharges, and water quality, were compiled from historical inventories contained in the USGS Ground Water Site Inventory and Water Quality data bases, the Wyoming State Engineer's Office data base (Wyoming State Engineer's Office, 1995), and from data collected in the field during 1993-95. These data were used to evaluate wells completed in and springs issuing from as many geologic units as possible, with as even a distribution across the county as possible. Data collected at each well or spring are used to estimate the quantity and quality of ground water at that site. Data collected for multiple wells completed in and springs issuing from a single geologic unit are used to estimate the extent of ground-water 
occurrence as well as the quantity and quality of ground water for that geologic unit in that area. Descriptions of selected geologic units contain information about the relation of ground water to geology; recharge, movement, and discharge of ground water; and water-level changes. Water-quality analyses of samples collected from wells completed in and springs issuing from different geologic units in the county are described in the Ground-Water Quality section of this report.

\section{Ground-Water Data}

The records for selected wells and springs throughout Lincoln County are listed in table 11 (at back of report). The sites in table 11 are sorted first according to the geologic unit a well was completed in or a spring issued from. Within each geologic unit, sites then were sorted by the station number. Locations of the wells and springs are shown on plate 3 . The records include the station and the local number, date drilled, depth of well, primary use of water, altitude of land surface, water level, and discharge.

Wells and springs are identified by location in this report. The sites are assigned a station number-a 15 digit code consisting of the latitude, longitude, and a sequence number (fig. 7). For example, site 423230110421501 refers to the first site inventoried at a location having a latitude of 42 degrees, 32 minutes, and 30 seconds, and a longitude of 110 degrees, 42 minutes, and 15 seconds. The last two digits in the station number are a sequence number indicating the order of inventory.

When available, the site also is assigned a local number according to the Federal township-range system of land subdivision. An example of a local number used in this report is 21-116-36dcd01 (fig. 7). The first number (21) denotes the township ( $T$ ), the second number (116) denotes the range (R), and the third number denotes the section. The first letter following the section number denotes the quarter section (160-acre tract), the second letter, if shown, denotes the quarter-quarter section (40-acre tract), the third letter, if shown, denotes the quarter-quarter-quarter section (10-acre tract). These subsections are designated $\mathrm{a}, \mathrm{b}, \mathrm{c}$, and $\mathrm{d}$ in a counterclockwise direction beginning in the northeast quarter. The last two digits in the local number are a sequence number indicating the order of inventory. Well $21-116-36 \mathrm{dcd} 01$ is the first well inventoried in the southeast quarter of the southwest quarter of the southeast quarter of section 36, T. 21 N., R. $116 \mathrm{~W}$.

In addition to the ground-water data published in this report, ground-water data are published in: (1) previous USGS investigation reports (such as, Welder, 1968, Lines and Glass, 1975, and Lickus and Law, 1988); (2) USGS Water Resources Data reports (published annually); and (3) various ground-water reports for the State. Ground-water data can also be obtained from USGS computer files. Requests for electronic data and/ or published reports can be made to the District Chief, U.S. Geological Survey, 2617 E. Lincolnway, Suite B, Cheyenne, Wyoming 82001-5662. Information such as well construction, initial water level, lithology, and well yields can be obtained from the Wyoming State Engineer. Inquiries should be made to the Groundwater Division Administrator, Herschler Building, 4th Floor-East, Cheyenne, Wyoming 82002.

\section{Relation of Ground Water to Geology}

Ground water refers to the subsurface water that is in the zone of saturation where soil and geologic formations are fully saturated. Ground water occurs in rocks in the primary openings between grains and in secondary openings, including fractures and openings from dissolution. Porosity, a measure of the void space in a rock, and permeability, a measure of the ability of a porous medium to transmit fluids, are important physical properties that affect the ability of a geologic unit to store water and to yield water to wells or springs. The source of the ground water could be one or a combination of the following: connate water, water trapped in the interstices of a sedimentary rock at the time of deposition; infiltration of precipitation; irrigation water; surface 


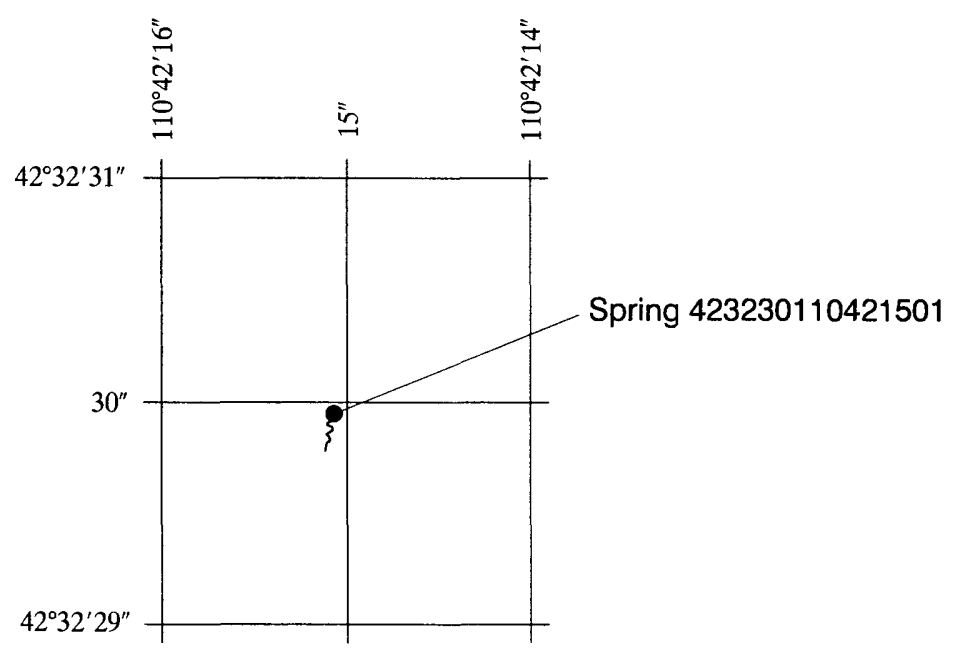

System for numbering wells and springs using latitude and longitude.

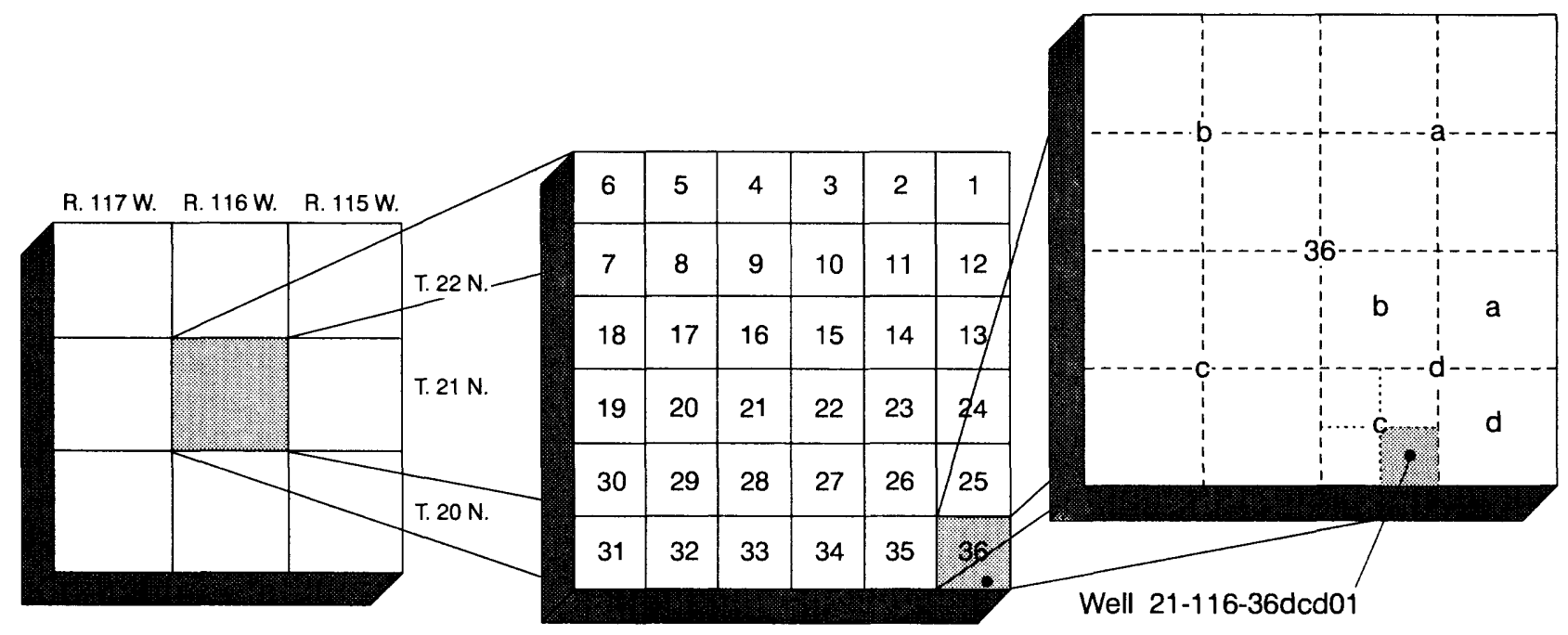

System for numbering wells and springs in surveyed townships.

Figure 7. Systems for numbering wells and springs. 
water; or leakage from other geologic units. Even though water-yielding capabilities or aquifer characteristics of all the geologic units in Lincoln County have not been quantified, some geologic units are known to have better water-yielding capabilities than others.

The lithology and water-yielding characteristics of 53 geologic units in Lincoln County are summarized in table 12 (at the back of report). For this report, terrace deposits, which may be included as Quaternary age geologic units or as a separate unit, are undifferentiated. Ranges of thickness and most common water yields from these geologic units are included in table 12. Well yields are a function of the diameter of the well, well casing, pump capacity and efficiency, as well as the thickness of the saturated interval penetrated, the hydraulic conductivity, and the density and viscosity of the fluid.

The surface distribution of these geologic units is shown on the geologic map (pl. 1). The geologic map in this report is modified from the State geologic map by Love and Christiansen (1985, sheet 1). Because of the scale of the map, some of the members within a formation are not shown on plate 1 but are listed in table 12 . For example, plate 1 shows the Green River Formation of Tertiary age, but table 12 describes the lithology and water-yielding characteristics of the Fossil Butte Member of the Green River Formation.

Wells completed in and springs issuing from the geologic units inventoried either for this study or for previous studies are listed in table 11. Inventory measurements of wells may have included a water level or a discharge or both. Inventory measurements of springs may have included a discharge measurement.

Water levels typically are measured using a steel tape. Water levels also can be measured using a sonic, electrical, or pressure-change-sensing device. Static water levels reflect the geologic unit's geohydrologic characteristics. However, effects beyond the investigator's control can make accurate measurements of the static water level difficult. For example, a well that is pumping water, that has been pumped recently, or is located near another pumping well will have a water level lower than the static water level as a result of drawdown in the well caused by the pumping. If a water level is affected by one of these situations, it is indicated in table 11. When a range of water levels is noted in the following section, the range is only for measured static water levels. Reported or estimated water levels also are excluded from the range but might be referenced in the text. The source of reported or estimated water levels is usually from other government agency data bases, driller's logs, or the well owner.

Discharge measurements of water typically are made using a weir, flume, flow meter, or volumetric method. Discharge from a flowing well or undeveloped spring represents the geologic unit's true water-yielding characteristics. The discharge from a pumped well is affected by the bore-hole diameter, pump capacity and efficiency, type and size of openings in the casing, type of filter pack, and thickness and permeability of the saturated interval penetrated. In this report, the range of discharges listed for wells and springs includes measured, reported, or estimated discharges, and measured discharges affected by pumping. The source of reported or estimated discharges is usually from other government agency data bases, driller's logs, the well owner, or field hydrologists.

The water-bearing characteristics of the geologic units in Lincoln County are discussed in the following three sections. The units are organized by geologic age and discussed from youngest to oldest: Cenozoic, (including deposits of Quaternary age, and rocks of Tertiary age), and rocks of Mesozoic and Paleozoic age. The following discussions are limited to the 35 geologic units with inventoried sites during this and previous studies (table 11). The same units and organization are used in the Ground-Water Quality section of this report.

\section{Quaternary Deposits}

Deposits of Quaternary age in the county consist of alluvium and colluvium; gravel, pediment, and fan deposits; glacial deposits; landslide deposits; and dune sand and loess (table 12). Terrace deposits can occur as 
Quaternary unconsolidated alluvium, within the unconsolidated gravel, pediment, and fan deposits, and can occur as partially consolidated gravels of Quaternary or Tertiary age. Lithologies and water-bearing characteristics, described in table 12, vary for each geologic unit. Quaternary deposits with sites inventoried during this and previous studies include alluvium and colluvium, glacial deposits, landslide deposits, and terrace deposits (table 11). All wells completed in and springs issuing from terrace deposits were assigned to Quaternary terrace deposits. More wells and springs were identified as completed in or issuing from Quaternary deposits than all other geologic units. Well depths ranged from 1 to 300 feet. Discharge from wells and springs ranged from 2 to 2,000 gallons per minute.

Quaternary alluvium and colluvium had the most water development of any geologic unit in the county, as well as the majority of the sites inventoried in overall Quaternary deposits (106 wells and 5 springs).

Quaternary alluvium and colluvium occur along major streams, including the Hams Fork, Bear and Salt Rivers, and La Barge Creek. Deposits consist of clay, silt, sand and gravel. Yields from wells completed in alluvium and colluvium are dependent on the thickness of the unit and the size and sorting of materials. Yields from wells completed in alluvium and colluvium of the Hams Fork River were more variable than yields from wells completed in alluvium and colluvium of the Bear River, Salt River, and La Barge Creek. This variability may be the result of different parent material in the alluvium and colluvium and channel meandering characteristics of the Hams Fork River. Aquifer productivity increases where thick sands and gravels predominate. Well depth was variable in alluvium and colluvium and was commonly more than 100 feet deep. Water from these sites was used primarily for domestic supplies. The most productive alluvial and colluvial aquifers in the Overthrust Belt are located in the valleys of the Bear River and Salt River (Star Valley) (Ahern and others, 1981, p. 71). Irrigation wells in the Bear and Salt River valleys may yield up to 2,000 gal/min (Lines and Glass, 1975, sheet 1).

Of the remaining inventoried sites for Quaternary deposits, seven wells were completed in and four springs issued from terrace deposits, two springs issued from glacial deposits, and four springs issued from landslide deposits. Terrace deposits occur in the Green River Basin and the Overthrust Belt; however, all the wells and springs inventoried completed in or issuing from terrace deposits were located in the Overthrust Belt. All six of the springs issuing from glacial and landslide deposits were located in the Overthrust Belt. Discharge from the springs was variable.

\section{Tertiary Rocks}

Rocks of Tertiary age are widely distributed in the Green River and Fossil Basins, and Star Valley. Springs are the dominant site type issuing from Tertiary rocks. Tertiary (Pliocene and Miocene) water-bearing units include the Salt Lake and Teewinot Formations. Tertiary (Eocene and Paleocene) water-bearing units include the Fowkes Formation; the Bridger Formation; the Green River Formation, the Laney, Wilkins Peak, Angelo, and Fossil Butte Members of the Green River Formation; the Wasatch Formation, including the New Fork Tongue and La Barge and Chappo Members; and the Evanston Formation. The Evanston Formation of Paleocene age extends into the Upper Cretaceous; however, for this report, the one well completed in and the three springs issuing from the Evanston Formation are listed in the Tertiary. The individual geologic unit was not determined for three Tertiary sites.

The Salt Lake and Teewinot Formations occur as surficial rocks in Star Valley (pl. 1). Love and Christiansen (1985, sheet 1) distinguish between these geologic units; however Lines and Glass (1975, sheet 2) and Oriel and Platt (1980, sheet 1) show only the Salt Lake Formation occurring in Star Valley. For this report, wells completed in and springs issuing from the Salt Lake and Teewinot Formations are not differentiated. The Salt Lake and Teewinot Formations have a maximum thickness of about 1,000 feet (Lines and Glass, 1975, sheet 1). Inventoried wells completed in the Salt Lake and Teewinot Formations range from 70 feet to 309 feet in depth. Typically, the largest expected yield of water from wells is a few tens of gallons per minute (Lines and 
Glass, 1975, sheet 1). Fracture permeability locally may produce large yields in the Salt Lake and Teewinot Formations (Lines and Glass, 1975, sheet 1). The yield from a spring used for water supply by the Town of Thayne was $2,200 \mathrm{gal} / \mathrm{min}$.

The youngest Eocene deposits of Tertiary age include the Bridger Formation in the Green River Basin and the Fowkes Formation in the Overthrust Belt. The Bridger Formation is an areally extensive formation in the southern part of the Green River Basin. Springs commonly issue from the Bridger Formation on hillsides; yields from springs range from 2 to $100 \mathrm{gal} / \mathrm{min}$ (Ahern and others, 1981, p. 46). The two wells inventoried during this study or previous studies had discharges of 6 and $13 \mathrm{gal} / \mathrm{min}$. The Fowkes Formation occurs as a surficial geologic unit in the southwestern corner of the Overthrust Belt in Lincoln County, and is composed primarily of tuffaceous sandstone and siltstone (table 12). Three springs issuing from the Fowkes Formation were inventoried; yields from springs ranged from 2 to $125 \mathrm{gal} / \mathrm{min}$.

Most of the Tertiary sites inventoried were completed in or issue from the Green River and Wasatch Formations and their members, ( 25 wells and 40 springs). The intertonguing of these deposits makes differentiating individual geologic units difficult. The Green River and Wasatch Formations generally contain water under artesian pressure in the Green River Basin (Welder, 1968, p. 2). A topographic barrier (Oyster Ridge) separated Fossil Basin and the Green River Basin during the deposition of several Green River Formation members (Oriel and Tracey, 1970, p. 5). The Laney Member of the Green River Formation occurs in the Green River Basin where 10 wells are completed in and 1 spring issues from the member. Yields from wells completed in the Laney Member generally range from 1 to $75 \mathrm{gal} / \mathrm{min}$ (Ahern and others, 1981, p. 68). One spring issued from the Angelo Member and one spring issued from the Wilkins Peak Member of the Green River Formation. The Fossil Butte Member of the Green River Formation occurs in Fossil Basin in the Overthrust Belt. Twelve springs issued from the Fossil Butte Member. The maximum discharge of springs inventoried for this study or previous studies was $200 \mathrm{gal} / \mathrm{min}$. The Wasatch Formation was the source of water for 15 wells and 25 springs. In general, wells completed in the Wasatch Formation were located in the Green River Basin at depths greater than 100 feet and springs that issued from the Wasatch Formation were located in the Overthrust Belt. The thickness of the Wasatch Formation ranges from 2,500 to 3,600 feet in the Overthrust Belt and from 4,100 to 5,250 feet in the western Green River Basin (Ahern and others, 1981, p. 46). Well yields from the sandstones and conglomerates of the Wasatch Formation range from 1 to $1,300 \mathrm{gal} / \mathrm{min}$, although most are less than $50 \mathrm{gal} / \mathrm{min}$ (Ahern and others, 1981, p. 67).

The Evanston Formation underlies the Wasatch Formation in the Overthrust Belt. One well completed in and three springs issuing from the Evanston Formation were inventoried for this study or previous studies in Lincoln County.

\section{Mesozoic Rocks}

Rocks of Mesozoic age occur surficially in north-south trending belts parallel to thrust faults in the Overthrust Belt in Lincoln County. Mesozoic rocks include water-bearing units of Cretaceous, Jurassic, and Triassic age. Cretaceous water-bearing units include the Adaville Formation, Blind Bull Formation, Hilliard Shale, Frontier Formation, Sage Junction Formation, Aspen Shale, Thomas Fork Formation, Bear River Formation, and the Gannett Group (table 12). Jurassic water-bearing units include the Stump Formation, Preuss Sandstone or Preuss Redbeds, and the Twin Creek Limestone. The Nugget Sandstone is a Jurassic(?) and Triassic(?) age water-bearing unit. Triassic water-bearing units include the Ankareh Formation, the Thaynes Limestone, the Woodside Shale, and the Dinwoody Formation.

Of the 50 sites with wells completed in or springs issuing from Cretaceous rocks, 40 sites were springs and 10 sites were wells (table 11). Wells inventoried for this study or previous studies were completed in the Adaville Formation (6); Hilliard Shale (1); Aspen Shale (2); and Bear River Formation (1). Yields of water from wells completed in Cretaceous aquifers generally were less than $30 \mathrm{gal} / \mathrm{min}$. Well depths ranged from 100 to 
1,200 feet. Springs issued from the Blind Bull Formation (1); Hilliard Shale (3); Frontier Formation (4); Sage Junction Formation (1); Aspen Shale (10); Bear River Formation (6); Thomas Fork Formation (2); and the Gannett Group (13). Discharge from springs was variable, ranging from less than 1 to about 700 gallons per minute. Cretaceous geologic units generally are considered minor aquifers in the Overthrust Belt. The Hilliard Shale is a major regional confining unit of the Green River Basin and Overthrust Belt, but locally produces water from a sandstone layer. The primary use of springs is for watering livestock.

Of the 28 sites in Jurassic or Jurassic(?)-Triassic(?) rocks, 27 sites were springs (table 11). Springs issued from the Stump Formation (1); Preuss Sandstone or Preuss Redbeds (3); Twin Creek Limestone (5); and the Nugget Sandstone (18). Only one well was completed in Nugget Sandstone, which is considered a major aquifer (Ahern and others, 1981, p. 55). Thickness of the Nugget Sandstone varies from about 600 feet in depth in the Green River Basin to about 1,300 feet in depth in the Overthrust Belt (table 12). Springs issue from the Nugget Sandstone where secondary permeability (fractures) occurs. The maximum discharge of water yielded from a spring issuing from the Nugget Sandstone was 1,400 gal/min (table 11).

Wells and springs inventoried from rocks of Triassic age include: Thaynes Limestone (6 springs and 2 wells), Woodside Shale ( 2 springs and 1 well), and Dinwoody Formation ( 2 springs). The Thaynes Limestone is the most productive aquifer in the Triassic system; flow from springs may be as large as 1,800 gal/min (Ahern and others, 1981, p. 56) (table 12). Wells completed in the Thaynes Limestone ranged from 195 feet to 600 feet (table 11). The Woodside Shale and Dinwoody Formation in general are impermeable. Discharge from springs issuing from the Woodside Shale and Dinwoody Formation ranged from 2 to $50 \mathrm{gal} / \mathrm{min}$.

\section{Paleozoic Rocks}

Like the younger rocks of Mesozoic time, surficial rocks of Paleozoic time occur parallel to the major thrust faults in the Overthrust Belt in Lincoln County. Paleozoic rocks include the Phosphoria Formation and related rocks of Permian age which are synonymous to the Park City Formation (Lane, 1973); the Tensleep Sandstone and the Wells Formation of Permian and Pennsylvanian age; the Amsden Formation of Pennsylvanian and Mississippian age; the Madison Limestone of Mississippian age; the Darby Formation of Mississippian and Devonian age; the Laketown Dolomite of Silurian age; the Bighorn Dolomite of Ordovician age; and the Gallatin Limestone, Gros Ventre Formation and Flathead Sandstone of Cambrian age (table 12). Sites inventoried in some of these units include wells completed in and springs issuing from the Tensleep Sandstone, the Wells Formation, the Madison Limestone, the Darby Formation, and the Bighorn Dolomite.

One well completed in and one spring issuing from the Phosphoria Formation and related rocks in the southwestern part of Lincoln County were inventoried for this study or previous studies. Locally the Phosphoria produces water where the rock is fractured (Lines and Glass, 1975). Discharge was $200 \mathrm{gal} / \mathrm{min}$ from the well and $300 \mathrm{gal} / \mathrm{min}$ from the spring (table 11).

Sandstone aquifers in Paleozoic rocks include the Tensleep Sandstone and the Wells Formation. Yields of water range from about 200 to 700 gal.min (table 12). Availability of water is dependent on depth of formation, continuity of beds within a formation, and development of fracture permeability. The Tensleep Sandstone is a white to gray sandstone containing thin limestone and dolomite beds (Lines and Glass, 1975). The well-sorted sand grains of the Tensleep enhance primary permeability, and secondary permeability is excellent where the unit is fractured (Lines and Glass, 1975). Two springs issue from the Tensleep Sandstone in the northern part of the county where the unit occurs at shallow depths. The Wells Formation is a thick interbedded quartzite, calcareous sandstone, and limestone. One well was completed in and four springs issued from the Wells Formation.

Paleozoic limestone and dolomite aquifers in Lincoln County include the Madison Limestone, the Darby Formation, and the Bighorn Dolomite. Permeability in these units is mostly secondary as a result of solution 
openings and fractures. Where geologic units with carbonate minerals exist at or near the earth's surface, dissolution is enhanced by reactions involving carbonate minerals with water and carbon dioxide from the atmosphere. Carbonic acid, which is derived from rainwater containing carbon dioxide acquired during its passage through the atmosphere, reacts with the carbonate minerals in the soil. If the carbonate minerals are not present in sufficient quantities to neutralize the carbonic acid, carbonate minerals in the rock will react and rock material will pass into solution. Geologic units occurring at topographic highs are probably drained to depths of several hundred feet (Lines and Glass, 1975, sheet 1). In Lincoln County, these units occur on the surface in the Overthrust Belt and in the subsurface in the Green River Basin. All 13 sites inventoried in these units were springs. Discharge was variable from the springs; the largest discharge was greater than $15,000 \mathrm{gal} / \mathrm{min}$. Periodic Spring, near the town of Afton (site 424440110505001) issues from the Madison Limestone. During the inventory site visit, discharge from this spring cycled from $10 \mathrm{gal} / \mathrm{min}$ for about 18 minutes, changing quickly to an estimated discharge of $15,000 \mathrm{gal} / \mathrm{min}$ for about 18 minutes (table 11). The water discharging from the spring is intercepted by a cave, whose outlet creates a siphon, turning the flow "on" and "off" (Blanchard, 1990). Blanchard, 1990, describes a detailed theory of the process. Based on data from the Overthrust Belt, the Madison Limestone is the most productive aquifer in the county (Ahern and others, 1981, p. 53).

\section{Recharge, Movement, and Discharge}

Geologic units in Lincoln County are recharged by one or a combination of the following sources: (1) precipitation that infiltrates the geologic unit in its outcrop area, (2) losing reaches of streams where surface water infiltrates into the geologic unit because the stream's water level is higher than the ground-water level, (3) infiltration of irrigation water, and (4) leakage from another geologic unit from either above or below.

Ground-water movement is controlled by the altitude of the location of recharge and discharge areas, and by the thickness and permeability of the geologic unit. Primary permeability is a function of the grain size, sorting, and cementation between grains. Secondary permeability created by fracturing and dissolution also is an important factor controlling ground-water movement. Fractures along structural features can provide important conduits for vertical and horizontal ground-water flow. Faults may affect ground-water movement where hydrologic properties differ between adjacent rocks. Faults may serve as either ground-water conduits or barriers, depending on the rock type and degree of fracturing (Freethey and Cordy, 1991, p. C8).

Ground water is discharged naturally in Lincoln County by one or a combination of the following mechanisms: (1) intersection of the water table with the land surface, (2) evapotranspiration, (3) leakage from one geologic unit to another, or (4) intersection of water table with streams. Springs and seeps occur in Lincoln County where the local water table intersects the land surface. Changes in lithology or topography, fractures, and faults may produce springs and seepage areas. Ground water in alluvium and colluvium usually discharges to local streams. Ground-water discharge also occurs as a result of human activity, by means of pumping wells.

The ground-water connection between the Overthrust Belt and the Green River Basin is restricted as a result of the folded and faulted rocks which are a result of regional tectonic (orogenic (mountain building)) activity during the middle Mesozoic and early Cenozoic time. These rocks of Mesozoic and Paleozoic age define the boundary between these two regions. Ground-water movement is difficult to define by aquifer within the Overthrust Belt because of the numerous faults and fractures (Ahern and others, 1981, p. 74). Aquifers in the Overthrust Belt primarily of Paleozoic and Mesozoic age receive their recharge from direct infiltration of precipitation in outcrop areas. Most of the water discharged in the Overthrust Belt from limestone and dolomite aquifers, such as the Madison Limestone of Mississippian age, the Darby Formation of Devonian age, and the Bighorn Dolomite of Ordovician age is by means of springs (Lines and Glass, 1975, sheet 1). Water recharging these aquifers in one surface drainage basin may discharge in another surface drainage basin via interbasin transfers of ground water (Lines and Glass, 1975, sheet 1). Ground water recharge to alluvial and colluvial aquifers in Star Valley originates from four sources: (1) water percolating from streams near the heads of fan 
deposits around the margins of the valley, (2) percolation of water from irrigation diversions on the alluvium and colluvium, (3) infiltration of precipitation on the valley floor (Walker, 1965, p. C8), and (4) older geologic units that have been uplifted along faults and are topographically higher than the alluvial and colluvial aquifers (Lines and Glass, 1975, sheet 2).

Within the Green River Basin, ground-water movement generally is toward the center of the basin which lies in Sweetwater County, east of Lincoln County. Ground-water contributions to Mesozoic and Paleozoic age aquifers from outcrop areas is limited by the thrust faults (Ahern and others, 1981). Recharge to Tertiary aquifers is minimal in areas of high evapotranspiration and low precipitation (Ahern and others, 1981, p. 87). Recharge to aquifers of Quaternary age occurs from infiltration of precipitation, irrigation waters, and surface water during periods of high flow. Recharge to the Laney Member of Tertiary age does occur in some areas from leakage of irrigation waters through alluvium and colluvium (Ahern and others, 1981). Ground-water discharge principally is to tributaries of the Green River.

\section{WATER USE}

Total water use in Lincoln County in 1993 was estimated to be 405,000 million gallons (Mgal) (Ogle and others, 1996, p. 1). In the report by Ogle and others, water use estimates were divided into nine categories: public supply, self-supplied domestic, commercial, irrigation, livestock, industrial, mining, thermoelectric power, and hydroelectric power. These terms are defined in the glossary. Surface water was the source of about $397,000 \mathrm{Mgal}$ (98 percent) of the water used in the county, whereas ground water was the source for only about $7,000 \mathrm{Mgal}$ ( 2 percent) of the water used. Hydroelectric power generation and irrigation used the largest amount of water (table 5).

Table 5. Estimated ground water, surface water, and total water use in Lincoln County, Wyoming, 1993

(From Ogle and others, 1996)

\begin{tabular}{llll}
\hline & \multicolumn{3}{c}{$\begin{array}{c}\text { Estimated Water Use 1993 } \\
\text { (million gallons) }\end{array}$} \\
\cline { 2 - 4 } \multicolumn{1}{c}{ Category } & Ground water & Surface water & \multicolumn{1}{c}{ Total } \\
\hline Public supply & 1,870 & 299 & ${ }^{1} 2,160$ \\
Self-supplied domestic & 1.7 & 0 & 1.7 \\
Commercial & $2(72)$ & $2(45)$ & ${ }^{2}(117)$ \\
Irrigation & 5,170 & 153,000 & ${ }^{1} 158,000$ \\
Livestock & 163 & 40 & 203 \\
Industrial & $3(27)+49$ & 71 & ${ }^{3}(27)+120$ \\
Mining & 68 & 85 & 153 \\
Thermoelectric power & 0 & 5,900 & 5,900 \\
Hydroelectric power & 0 & 238,000 & 238,000 \\
TOTAL & ${ }^{1} 7,320$ & ${ }^{3} 397,000$ & ${ }^{1} 405,000$ \\
\hline
\end{tabular}

${ }^{1}$ Rounded totals.

${ }^{2}$ All commercial water use was from public supply, thus the numbers are reported (in parentheses), but are not added to the total

${ }^{3}$ Part of the industrial water use was from public supply, thus the numbers from the public supply are reported (in parentheses), but are not added to the total. 
Public supply and self-supplied domestic use accounted for 0.5 percent of the water used in Lincoln County. The source of water for public supplies in the county was primarily ground water from springs and wells, with the exception of the Kemmerer and Diamondville system, which was supplied by surface water from the Hams Fork River. Self-supplied domestic water is water withdrawn from a water source by a user rather than a public supplier. The source of water for self-supplied domestic water is primarily ground water.

Irrigation was the second largest water use in Lincoln County. An estimated total of $158,000 \mathrm{Mgal}$ (485,000 acre-feet) of water was used for irrigation in 1993 based on data provided by the Star Valley and Lincoln County Conservation Districts (Ogle and others, 1996, p. 6). Within the Star Valley Conservation District, surface water accounted for about 96 percent of the water applied to irrigated land. About 55 percent of the water was applied using sprinkler irrigation and about 45 percent of the water was applied using flood irrigation. Similar to the Star Valley Conservation District, the Lincoln County Conservation District also used surface water as the primary source of irrigation water (97 percent). In contrast to the Star Valley Conservation District, the Lincoln County Conservation District primarily uses flood irrigation (about 94 percent), with only a small percentage of water applied using sprinkler irrigation (about 6 percent) (Ogle and others, 1996, p. 6).

\section{WATER QUALITY}

Water quality refers to biological, chemical, and physical characteristics of a water sample in relation to a standard defined for drinking water or other water uses. Biological water quality is determined by the number and types of organisms, both plant and animal, living in water and is generally restricted to surface water. Only limited biological data have been collected for streams in Lincoln County; therefore, biological water quality is not described here. A general discussion of the chemical and physical characteristics of ground water and surface water follows. For a more thorough discussion of the biological, chemical, and physical characteristics of water, the reader is referred to Hem (1985) or Freeze and Cherry (1979).

The chemical characteristics of surface and ground water are derived from the organic and inorganic materials dissolved and suspended in the water. These dissolved and suspended materials are derived from the rocks and sediment with which the water has been in contact and from materials introduced into the hydrologic environment by human and animal activities. Surface-water quality is dependent on the water source and the exposure of the water to soluble or suspendable material between the source and the sampling site. Groundwater quality is related to the chemical composition of the rocks composing the geologic units through which the water travels. Water temperature, the duration of contact with the rocks, and the rate of movement of the water also will affect the chemical quality of ground water. The source or cause and significance of common dissolved-mineral constituents found in surface and ground water are summarized in table 6 . Nutrient samples from wells and spring in Lincoln County were analyzed for nitrite and nitrite plus nitrate. All concentrations of nitrite were much lower than the concentration of nitrite plus nitrate. Therefore, in this report, nitrite plus nitrate will be referred to as nitrate for discussion purposes.

For this study, inorganic materials in water are classified by the size of the particles, and are either dissolved solids or particulate material. Materials that will not pass through a 0.45 -micrometer $(\mu \mathrm{m})$ filter are operationally defined as particulate materials, and particles that will pass through a 0.45 -micrometer filter are operationally defined as dissolved solids (Hem, 1985, p. 60). Particulate material can be filtered from water, whereas dissolved solids require more sophisticated techniques for removal, such as reverse osmosis.

Chemical quality at a surface-water site is assumed to be a function of the materials in contact with the water, the duration of the contact, and the stream discharge at that site. The chemical quality can be described using either load or dissolved-solids concentrations. The load is calculated by multiplying the discharge at a site by the dissolved-solids concentration of a chemical in the water. Sites having large discharges have large loads, even though the dissolved-solids concentrations at the site are often small. 


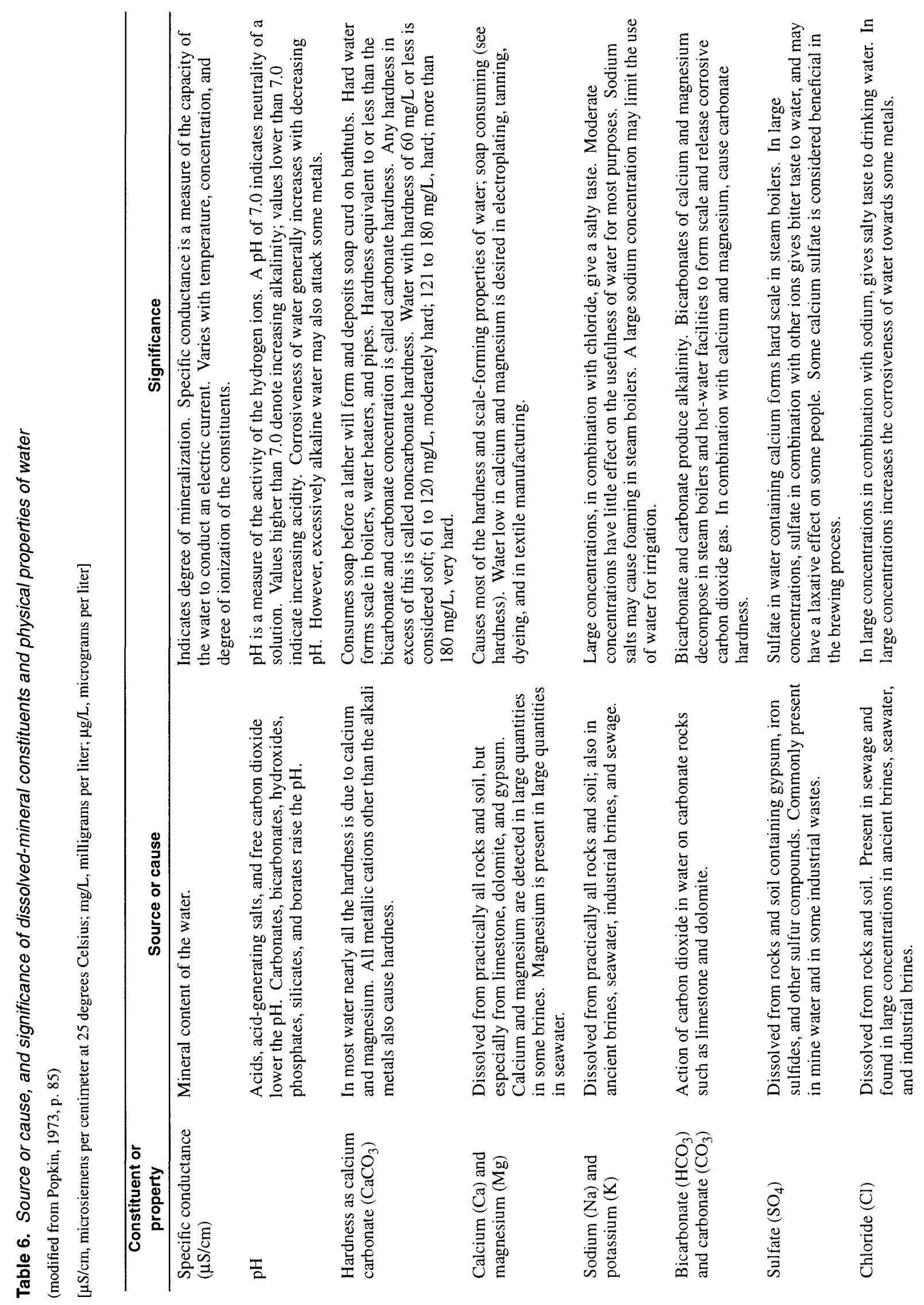




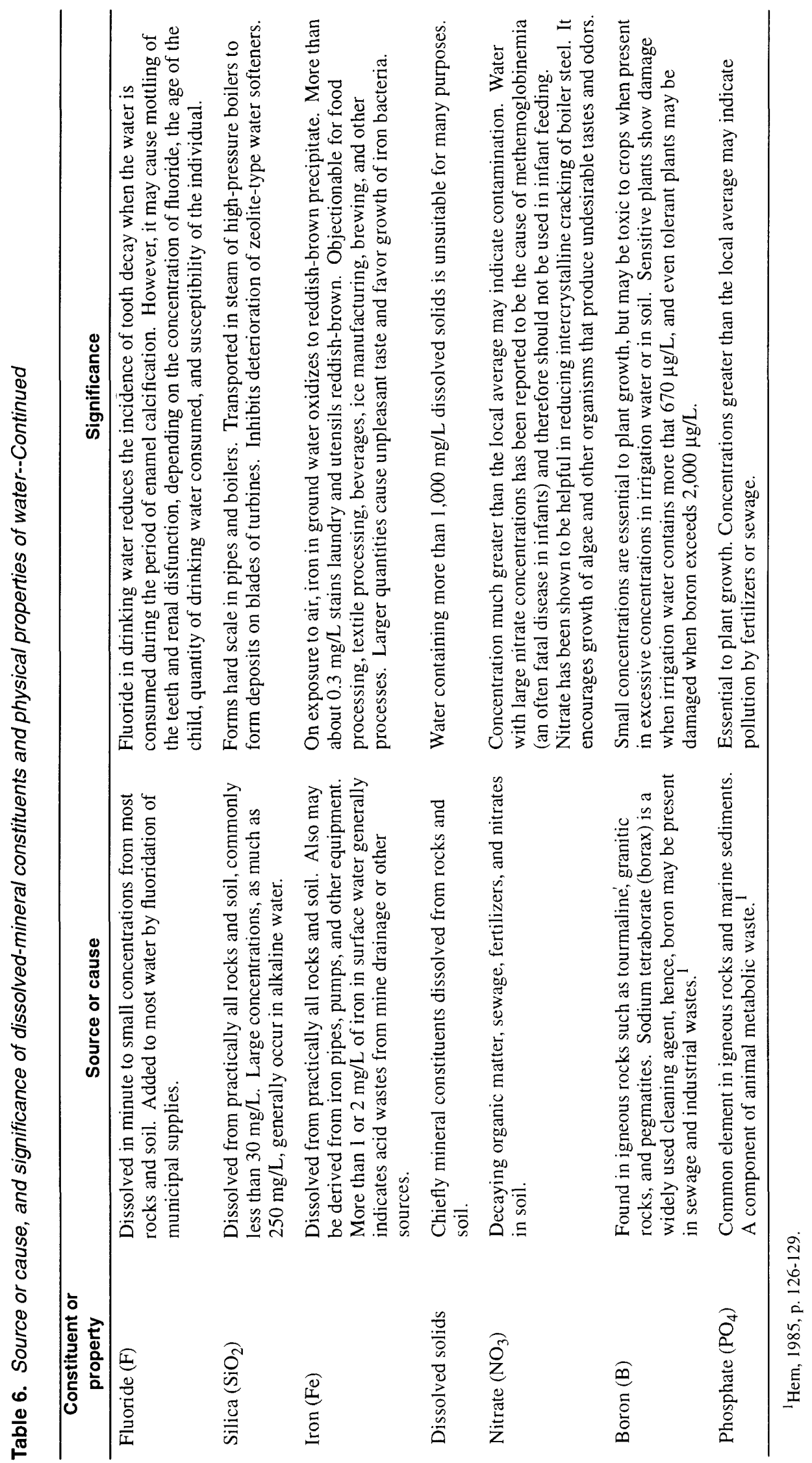


Water can be classified into types on the basis of amount and type of ions present in a water sample. The dominant ions are the cation (positive charge) and anion (negative charge) having the largest concentration expressed in milliequivalents per liter. A milliequivalent is a measurement of concentration, where the charge of the ion is accounted for. For example, in a sodium sulfate-type water, sodium has the largest concentration of the cations present, and sulfate has the largest concentration of the anions present. If a water sample does not contain a dominant cation and anion, the water is classified as a mixture of the cations and anions having the largest concentrations. Modified Stiff diagrams often are used to visually display cation and anion data. A modified Stiff diagram uses three parallel, horizontal axes, extending to the left and right of a vertical zero line. The concentrations of the four most common cations--sodium, potassium, magnesium, and calcium--are plotted on the left on each of the three horizontal lines (sodium and potassium are plotted as one constituent). The five most common anions--chloride, fluoride, sulfate, bicarbonate, and carbonate--are plotted on the right on each of the three horizontal lines (chloride and fluoride, and bicarbonate and carbonate are plotted as one constituent). Modified Stiff diagrams are used to describe the type of water in Lincoln County in the Ground-Water Quality Section.

Physical characteristics of water commonly measured onsite during water-quality studies include water temperature, specific conductance, and $\mathrm{pH}$. Temperature is an important controlling factor in many chemical processes; for example, the solubility of ions and the saturation level of gases are affected by water temperature. The temperature of surface water typically is much more variable than the temperature of ground water. Surface-water temperatures are affected by local climatic factors and physical factors such as shading, stream depth, and proximity to lakes and reservoirs. Ground-water temperatures generally are a function of the depth of the geologic unit below the surface of the earth. Water in deep geologic units generally has higher temperatures than water in shallow units.

Specific conductance is a measure of the ability of water to conduct electrical current. It is expressed in microsiemens per centimeter $(\mu \mathrm{S} / \mathrm{cm})$ at 25 degrees Celsius $\left({ }^{\circ} \mathrm{C}\right)$, and is a function of the concentration and type of dissolved solids in the water. The concentration of the sum of dissolved solids, in milligrams per liter $(\mathrm{mg} / \mathrm{L})$, typically ranges from 55 to 75 percent of the specific conductance in $\mu \mathrm{S} / \mathrm{cm}$ (Hem, 1985, p. 67). This relation varies with the composition and concentration of dissolved ions.

The measure of the hydrogen activity in water is $\mathrm{pH}$, which is defined as the negative logarithm of the hydrogen-ion concentration. This parameter is dimensionless and typically ranges from 0 to 14 . A pH greater than 7 indicates that the water is basic (alkaline), whereas a $\mathrm{pH}$ less than 7 indicates that the water is acidic.

A description of the chemical and physical characteristics of water aids in evaluating its suitability for various uses. Water-quality standards for chemical constituents or parameters adopted by the State of Wyoming and used for evaluating ground-water quality for domestic, agricultural, and livestock use are listed in table 7. Because of the variability of water quality at different sampling points and an insufficient number of water samples analyzed in the county, water samples reported here are not classified as suitable for specific uses. However, individual samples listed in tables in this report can be compared to the water-quality standards listed in table 7.

The U.S. Environmental Protection Agency (1996) has established primary and secondary drinking water standards applicable to public drinking-water supplies (table 8). These Federal regulations specify maximum allowable contaminant levels (MCLs) and secondary maximum contaminant levels (SMCLs). The MCLs are health related and legally enforceable. Although MCLs apply only to public drinking-water supplies, the levels are useful indicators of the suitability of water for human consumption. The SMCLs are standards primarily addressing the aesthetic qualities of drinking water, and are not legally enforceable. For example, chloride at concentrations exceeding $250 \mathrm{mg} / \mathrm{L}$ may impart a bitter taste to water. 
Table 7. Wyoming ground-water quality standards for domestic, agricultural, and livestock use (Modified from Wyoming Department of Environmental Quality, 1993, p. 9)

[All constituent concentrations are in milligrams per liter unless otherwise indicated. --, no established level; $\mu \mathrm{g} / \mathrm{L}, \mathrm{micrograms}$ per liter; "C, degrees Celsius]

\begin{tabular}{|c|c|c|c|}
\hline Constituent or property & $\begin{array}{c}\text { Domestic } \\
\text { use }\end{array}$ & $\begin{array}{c}\text { Agricultural } \\
\text { use }\end{array}$ & $\begin{array}{l}\text { Livestock } \\
\text { use }\end{array}$ \\
\hline Aluminum $(\mu \mathrm{g} / \mathrm{L})$ & -- & 5,000 & 5,000 \\
\hline Arsenic $(\mu \mathrm{g} / \mathrm{L})$ & 50 & 100 & 200 \\
\hline Barium $(\mu g / L)$ & 1,000 & -. & -- \\
\hline Boron $(\mu \mathrm{g} / \mathrm{L})$ & 750 & 750 & 5,000 \\
\hline Cadmium $(\mu \mathrm{g} / \mathrm{L})$ & 10 & 10 & 50 \\
\hline Chloride & 250 & 100 & 2,000 \\
\hline Chromium $(\mu \mathrm{g} / \mathrm{L})$ & 50 & 100 & 50 \\
\hline Copper $(\mu g / L)$ & 1,000 & 200 & 500 \\
\hline Fluoride & ${ }^{1} 1.4-2.4$ & -. & -- \\
\hline Iron $(\mu \mathrm{g} / \mathrm{L})$ & 300 & 5,000 & -- \\
\hline Lead $(\mu \mathrm{g} / \mathrm{L})$ & 50 & 5,000 & 100 \\
\hline Manganese $(\mu \mathrm{g} / \mathrm{L})$ & 50 & 200 & -- \\
\hline Mercury $(\mu \mathrm{g} / \mathrm{L})$ & 2 & -- & .05 \\
\hline Nitrate + nitrite, as nitrogen & 10 & -- & 100 \\
\hline Selenium $(\mu \mathrm{g} / \mathrm{L})$ & 10 & 20 & 50 \\
\hline Silver $(\mu \mathrm{g} / \mathrm{L})$ & 50 & -- & -- \\
\hline Sulfate & 250 & 200 & 3,000 \\
\hline Dissolved solids & 500 & 2,000 & 5,000 \\
\hline $\mathrm{pH}$, standard units & $6.5-9.0$ & $4.5-9.0$ & $6.5-8.5$ \\
\hline Sodium-adsorption ratio (no units) & -- & 8 & -- \\
\hline
\end{tabular}

\section{Quality Assurance and Quality Control}

During the study of the water resources in Lincoln County, quality-assurance and quality-control protocols were used to ensure the accuracy of the data collected and to assist in the interpretation of historical and collected data. Quality-control samples were collected to assess the adequacy of general water-quality sampling and analysis procedures and to identify factors that may have produced discrepancies in the data.

\section{Quality Assurance}

Quality assurance refers to proper office, field, and laboratory procedures. Office quality assurance involved review of historical data as well as evaluation of data collected during the 1993-95 field seasons. All historical data, collected in Lincoln County since 1945 as part of previous investigations or other data-collection activities, were screened before inclusion in this report. All data from surface- and ground-water samples, historical and collected during this study, were checked to ensure that the percent difference between the sum of the cations (in milliequivalents per liter (meq/L)) and the sum of the anions (in meq/L) was less than $+/-5$ percent. Because water is electrically neutral (the sum of cations equals the sum of the anions), the percent difference between the sum of the cations and the sum of the anions helps determine if the analytical results are accurate. Any data collected from sites that had samples with ionic balances that differed by more than 5 percent were evaluated to determine whether the data were to be included in this report. Only USGS historical data were examined. 
Table 8. Selected maximum and secondary maximum contaminant levels for public drinking-water supplies

(U.S. Environmental Protection Agency, 1996)

[All constituent concentrations are in milligrams per liter unless otherwise indicated. --, no established level; $\mu \mathrm{g} / \mathrm{L}$, micrograms per liter]

\begin{tabular}{lcc}
\hline Constituent or property & $\begin{array}{c}\text { Maximum } \\
\text { contaminant level }\end{array}$ & $\begin{array}{c}\text { Secondary maximum } \\
\text { contaminant level }\end{array}$ \\
\hline Inorganic & \\
Arsenic $(\mu \mathrm{g} / \mathrm{L})$ & 50 & -- \\
Barium $(\mu \mathrm{g} / \mathrm{L})$ & 2,000 & -- \\
Cadmium $(\mu \mathrm{g} / \mathrm{L})$ & 5 & -- \\
Chloride & -- & 250 \\
Chromium $(\mu \mathrm{gg} / \mathrm{L})$ & 100 & -- \\
Copper $(\mu \mathrm{g} / \mathrm{L})$ & 1,300 & \\
Fluoride & 4 & 2.0 \\
Iron $(\mu \mathrm{g} / \mathrm{L})$ & -- & 300 \\
Lead $(\mu \mathrm{g} / \mathrm{L})$ & 15 & -- \\
Manganese $(\mu \mathrm{g} / \mathrm{L})$ & -- & 50 \\
Mercury $(\mu \mathrm{g} / \mathrm{L})$ & 2 & -- \\
Nitrate, as nitrogen & 10 & -- \\
Selenium $(\mu \mathrm{g} / \mathrm{L})$ & 50 & -- \\
Silver $(\mu \mathrm{g} / \mathrm{L})$ & -- & 100 \\
Sulfate & 500 & 250 \\
Zinc $(\mu \mathrm{g} / \mathrm{L})$ & -- & 5,000 \\
Dissolved solids & -- & 500 \\
pH, standard units & -- & $6.5-8.5$ \\
& Organic & -- \\
2,4-D & .07 & -- \\
Picloram & .05 & \\
\hline
\end{tabular}

Quality assurance procedures for the field and laboratory were conducted during the 1993-95 field season. Field quality-assurance practices involved calibration of all field meters and probes, and cleaning of sampling equipment prior to all site visits. Immediately prior to each sampling, meters and probes were recalibrated. All calibration information was recorded on USGS water-quality field forms. Samples were collected, preserved, and shipped in accordance with applicable USGS protocols. Quality-assurance procedures used at the USGS National Water Quality Laboratory (NWQL) in Arvada, Colorado, constituted the laboratory quality-assurance program implemented for this study.

\section{Quality Control}

Two types of quality-control samples were collected during the 1993-95 field sampling: replicate samples and field-blank samples. Replicate samples, sometimes called splits, were collected from seven sites, and were obtained by dividing the water collected for each analysis into two bottles. The NWQL then analyzed the samples as two separate sites. The purpose of a replicate sample is to evaluate laboratory precision between samples. Fieldblank samples collected at 15 sites in the county were obtained by passing inorganic-free blank water through all components of the sample-collection apparatus. Chemical analysis of this water was designed to determine the adequacy of the process of equipment cleaning between sampled sites, or to quantify carryover of any chemical contamination between sites. 


\section{Streamflow Quality}

Natural and anthropogenic factors affect the water quality of streamflow: geology of the drainage basin, ground-water inflow, and land use. Hem (1985, p. 39) describes natural factors as "reactions of water with mineral solids in the streambed and in suspension, reactions among solutes, losses of water by evaporation and by transpiration from plants growing in and near the stream, and effects of organic matter and water-dwelling biota." Anthropogenic activities affecting streamflow water quality include farming, grazing, mining, disposing of waste, and diverting and augmenting streamflows.

Streamflow water quality is related to the mineral composition of the soil and rocks with which the water is in contact, and is therefore affected by the geology of the drainage basin and ground-water inflow. Sediment loads are related to the erodibility of the rocks and surficial materials in the drainage basin. Land uses in Lincoln County that might affect streamflow water quality are agriculture, mining, oil and gas development, waste disposal, and reservoirs.

The purpose of this section is to describe and evaluate the streamflow water quality in Lincoln County. Previous reports and current studies that include drainage basins in the county are discussed first. Statistical summaries of selected physical properties and chemical analyses were used to evaluate streamflow water quality for the three main drainage basins in Lincoln County. Surface-water samples collected during a sampling event July $18-23,1994$, were used to evaluate streamflow water quality in the Salt River.

Typically, streamflow water quality studies are done for a selected stream or drainage basin. All three basins that occur in the county, (the Green, Bear, and Snake River Basins (fig. 8)) were part of previous studies. The Snake and Bear River Basins are part of current investigations.

Water-quality in the Green River Basin is discussed in several reports published by the USGS (DeLong, 1977; DeLong and Wells, 1988; and Ringen, 1984). Salinity, dissolved solids, and suspended sediments were the primary constituents evaluated because they are the most commonly used factors to evaluate the suitability of water for various uses. In all three reports, a regression model was used to relate the constituent of concern to discharge. At least one streamflow site in Lincoln County was included in all three studies, but usually most of the study area was outside of the county.

DeLong (1986, p. 14-15) evaluated phosphate loads in the Green River because of concerns related to eutrophication and algal growth in the reservoirs on the river. Phosphate loads computed for sites upstream and downstream of Fontenelle Reservoir show that the reservoir traps phosphate. Storage rates were not computed because of the lack of data collected from runoff and tributary streams.

In a study of the water resources of the Overthrust Belt in western Wyoming, Lines and Glass (1975, sheet 3) used major ion data and dissolved-solids concentrations to describe water types and general water quality of samples collected from streams in the Green, Bear, and Snake River Basins. Water samples collected from streams in the southeastern part of the Bear River Basin and the southwestern part of the Green River Basin contained the largest concentrations of magnesium, sodium, sulfate, and chloride. In addition to the differences between drainage basins, Lines and Glass also showed that differences can occur between locations within the same drainage basin and that differences can occur seasonally at a single site.

Lowham (1985) summarized the physical and hydrologic features of a coal bearing area in the Northern Great Plains and Rocky Mountain Provinces, including the Green and Bear River Basins in Lincoln County. Streamflow quality is described using the following parameters: dissolved solids, $\mathrm{pH}$, total phosphorous, suspended sediment, bacteria, algae, invertebrates, fish, and water temperature. Boxplots of dissolved-solids concentration (Lowham, 1985, p. 42) show that most water samples collected from Green River near La Barge (site 4) and Bear River near the Wyoming-Idaho border (on the Idaho side) had concentrations less than $500 \mathrm{mg} / \mathrm{L}$. However, most water samples from Twin Creek at Sage (site 19), a tributary to the Bear River, had concentrations greater than $500 \mathrm{mg} / \mathrm{L}$. 


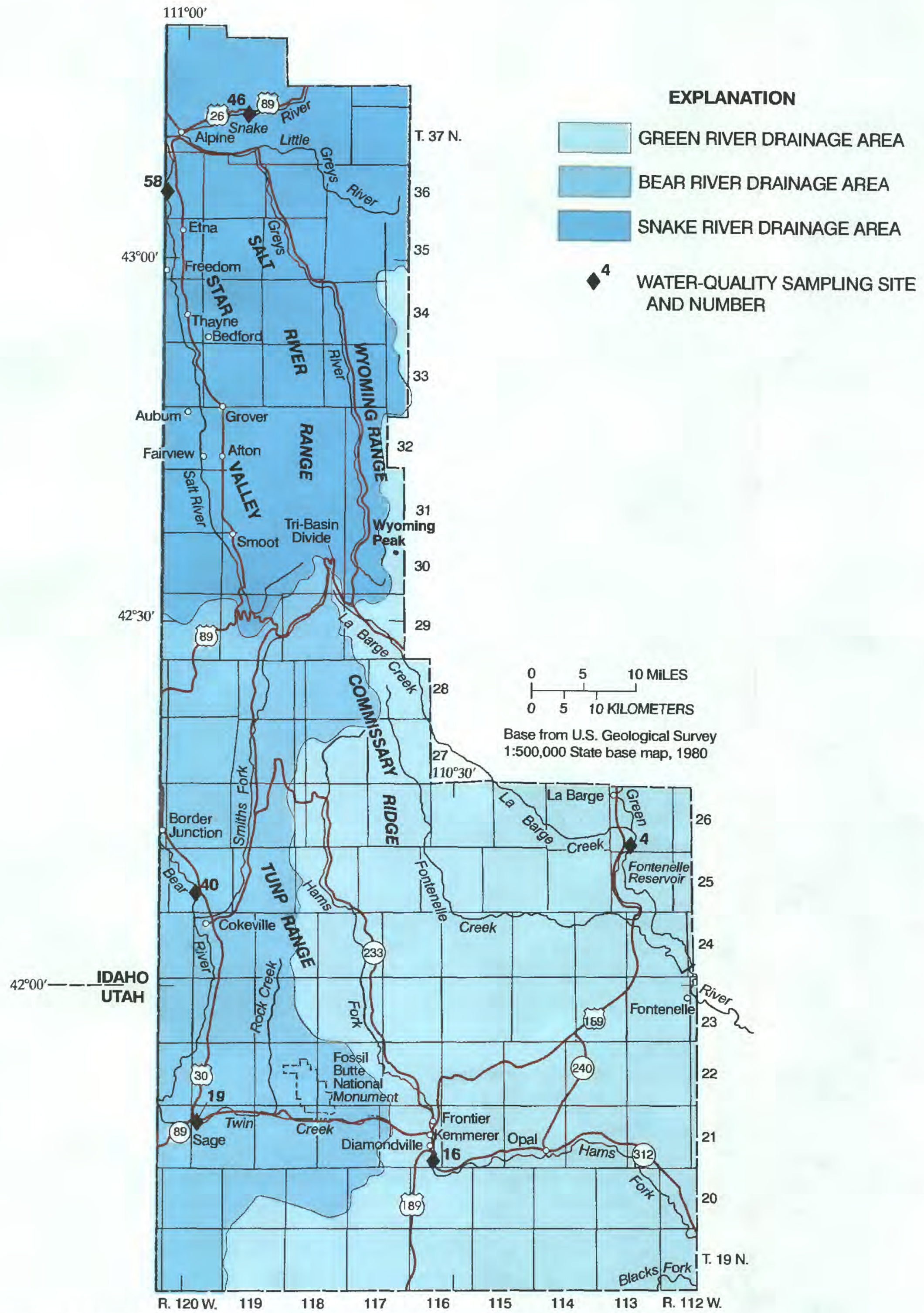

Figure 8. Location of the Green, Bear, and Snake River drainage areas in Lincoln County, Wyoming. 
In 1991, the USGS began implementing a full-scale National Water-Quality Assessment (NAWQA) program. The long-term goals of the NAWQA program are to describe the status and trends in the quality of a large, representative part of the Nation's surface- and ground-water resources, and to provide a sound, scientific understanding of the primary natural and human factors affecting the quality of these resources. The Snake River Basin in northern Lincoln County is part of the Upper Snake River NAWQA study that began in 1991. A report describing the quality of surface water "on the basis of nutrient, suspended sediment, and pesticide data" (Clark, 1994, p. 2) from 1975-89 was published in 1994. The Bear River Basin in southwestern Lincoln County is part of the Great Salt Lake NAWQA study that began in 1994.

In the Upper Snake River NAWQA study, water-quality samples were collected from the Salt River (Clark, 1994, p. 29). Upstream and downstream concentrations of nitrate were significantly different; whereas, concentrations of total phosphorus were not significantly different between the upstream and downstream stations on the Salt River. Differences in concentrations of dissolved ammonia, total nitrogen, and orthophosphate were not assessed because of a lack of data.

Statistical summaries (table 9) of selected physical properties and chemical analyses were used to evaluate the water quality for samples collected from streams and rivers in the Green, Bear, and Snake River Basins. The location of the three drainage basins within the county is shown on figure 8. Data are from the USGS water-quality data bases located in Wyoming, Utah, and Idaho Districts. Physical properties and major ion data were screened for duplication of analyses stored in the three data bases. Otherwise, all data were used in the statistical summaries. Values less than the NWQL reporting limit were assumed to equal half of the reporting limit for major ion and nutrient data and were assumed to equal the reporting limit for trace element, pesticide, and sediment data.

Water-quality samples collected at two streamflow sites in each drainage basin were used to summarize streamflow water quality. The sites selected were (table 1): Green River near La Barge (site 4) and Hams Fork near Diamondville (Kemmerer) (site 16), Green River Basin; Twin Creek at Sage (site 19) and Bear River below Smiths Fork, near Cokeville (site 40), Bear River Basin; Snake River above reservoir, near Alpine (site 46) and Salt River above reservoir, near Etna (site 58), Snake River Basin. These sites represent the farthest downstream location on the major tributaries in each drainage basin where a large number of water-quality data were collected. The statistical summary of water-quality constituents listed in table 9 should be considered only as a general condition of the streamflow water quality leaving the county in each drainage basin, because water-quality conditions can change from the headwaters to the lowest downstream point and seasonally at the same site.

General water quality of streamflow typically is described by the dissolved-solids concentration. Evaluating water quality in terms of dissolved-solids concentration or any other constituent is dependent on the use of the water. The SMCL for dissolved-solids concentration is $500 \mathrm{mg} / \mathrm{L}$ (U.S. Environmental Protection Agency, 1996) (table 8). Standards or guidelines for other constituents and other water uses are established by various Federal and State agencies, and by industry.

The median dissolved-solids concentration in water samples collected from the Bear River Basin is $563 \mathrm{mg} / \mathrm{L}$ (table 9). The dissolved-solids concentrations reported in this study are most representative of streamflow quality at Twin Creek, because most of the analyses (126 of 129) were from water samples collected at site 19. Boxplots of dissolved-solids concentrations for three sites in the Bear River Basin are presented in Larson (1985, p. 43). Larson shows a site on Twin Creek with a water sample having a median dissolved-solids concentration greater than $500 \mathrm{mg} / \mathrm{L}$ and dissolved-solids concentration in the same range as site 19 . The samples from two mainstem sites on the Bear River had median values less than $500 \mathrm{mg} / \mathrm{L}$ (Larson, 1985, p. 43).

Lines and Glass (1975, sheet 3) attributed higher concentrations of magnesium, sodium, sulfate, and chloride in the southern part of the Overthrust Belt area to the composition of Tertiary rocks, low precipitation, and high evapotranspiration in the area. Median concentrations of the same constituents (table 9) are larger in the Bear River Basin, which drains part of the southern Overthrust Belt area, than in the Green and Snake River Basins. 


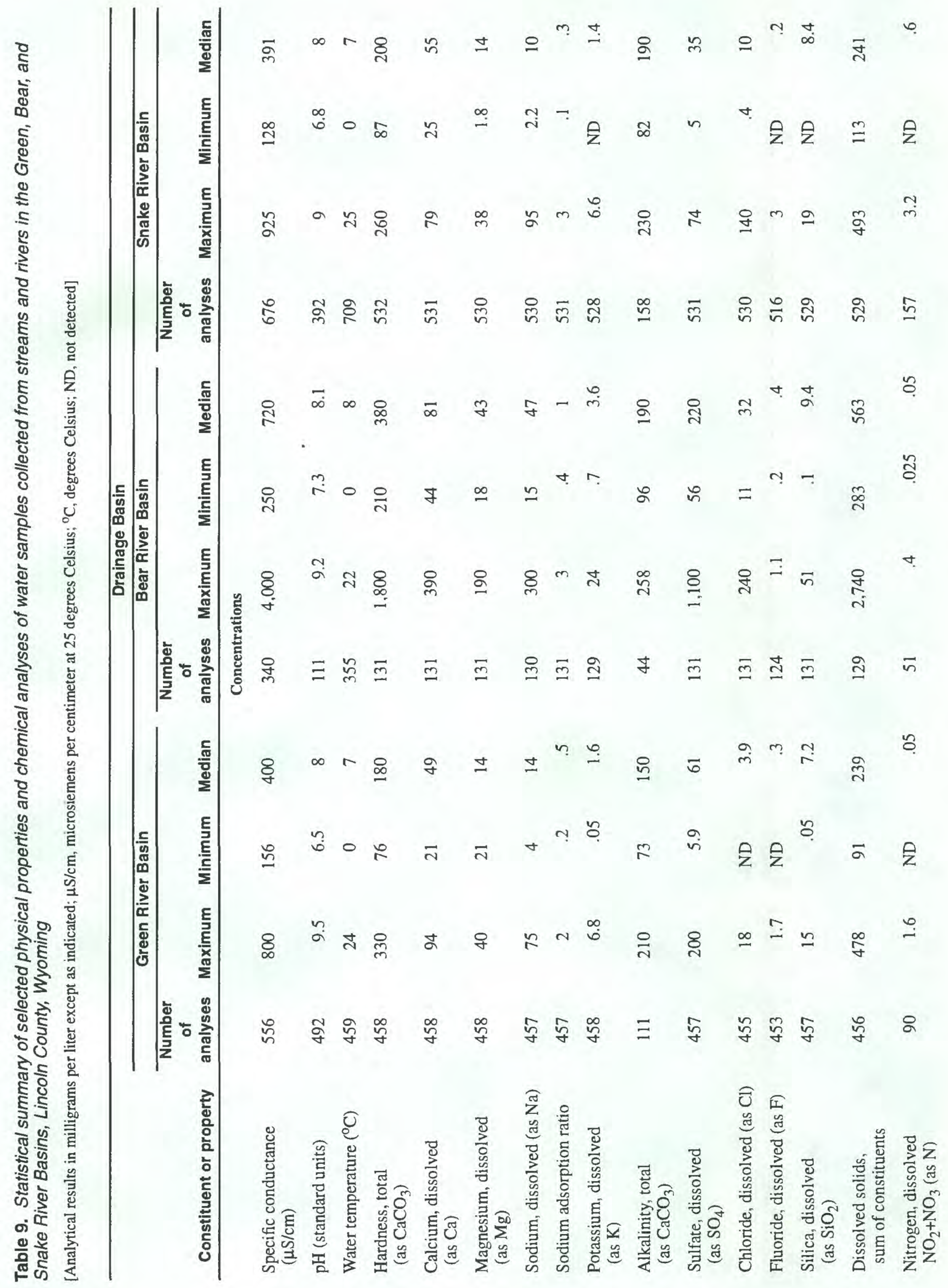




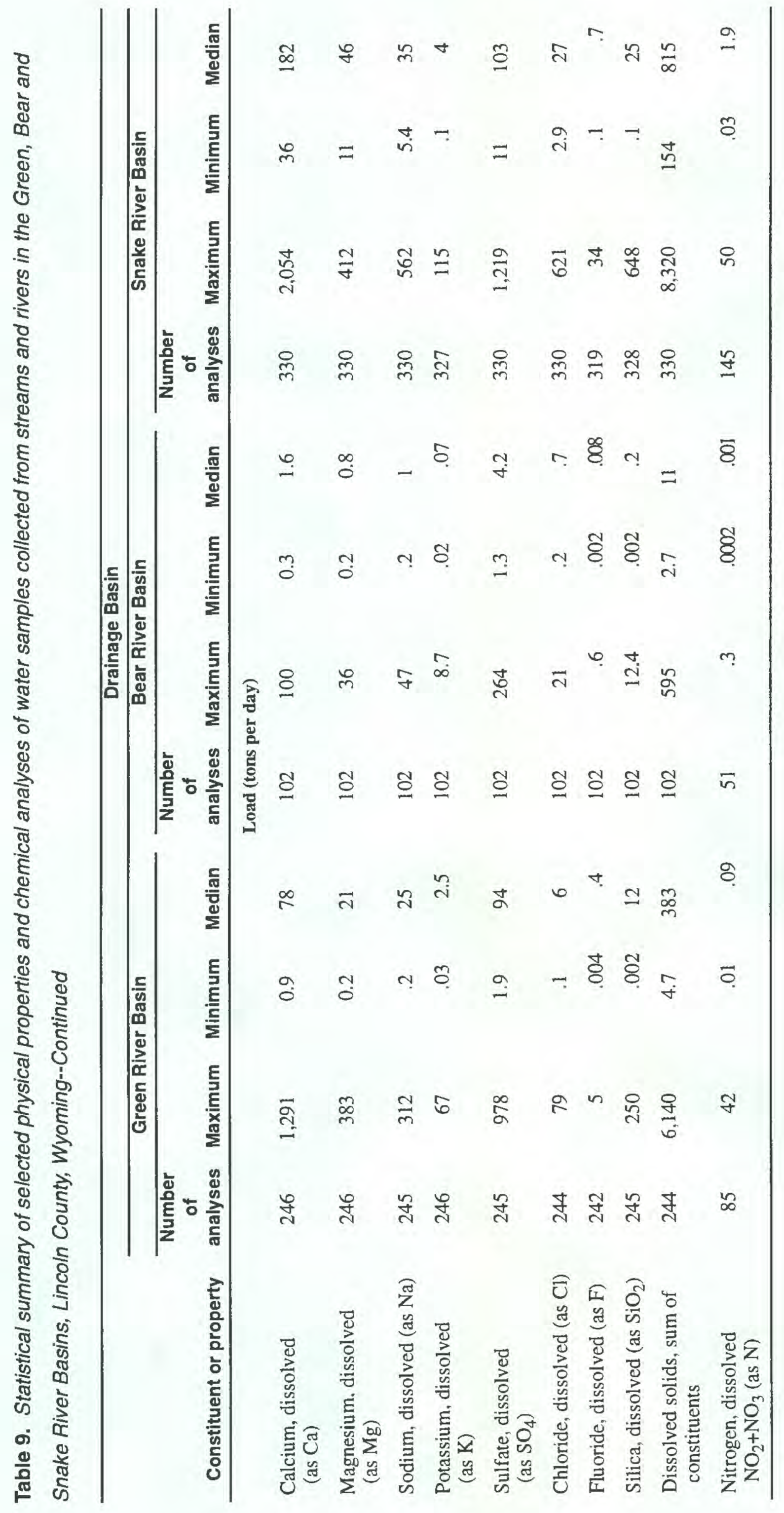


The source of nitrogen in streamflow varies and can be anthropogenic or natural. Anthropogenic sources include septic tanks, barnyards, and nitrogen fertilizer. The median nitrate concentration in surface-water samples collected from all three drainage basins is less than the MCL of $10 \mathrm{mg} / \mathrm{L}$ as nitrogen (U.S. Environmental Protection Agency, 1996). Samples from the Snake River Basin have the highest nitrate concentrations (median $=0.6 \mathrm{mg} / \mathrm{L}$ as nitrogen; table 9 ). Sixty-seven percent (125 of 186) of the samples used in the analysis are from Salt River above reservoir near Etna (site 58), which drains the agricultural area in Star Valley. Greys River above (Palisades) reservoir, near Alpine (site 49), is also in the Snake River Basin, but drains an area unaffected by agriculture. However, no historical data were available from site 49 to include in the statistical summary.

The Wyoming, Utah, and Idaho District data bases were queried for analytical data for the following pesticides: ethion, malathion, parathion, diazinon, methyl parathion, picloram, 2,4-D, 2,4,5-T, silvex, ethyl trithion, methyl trithion, dicamba, and 2,4-DP. Water-quality samples collected from Twin Creek at Sage (site 19) and Bear River below Smiths Fork, near Cokeville (site 40) in the Bear River Basin were analyzed for these 13 pesticides. Picloram, 2,4-D, and dicamba were detected in water samples collected from sites in both the Green and Snake River Basins. All pesticide results for picloram, 2,4-D, and dicamba were less than the MCL or proposed drinking water equivalent level (U.S. Environmental Protection Agency, 1996). The MCL for picloram is $0.5 \mathrm{mg} / \mathrm{L}$ and for 2,4-D is $0.07 \mathrm{mg} / \mathrm{L}$. The USEPA has not established an MCL for dicamba, but the proposed drinking water equivalent level in the Generic State Pesticide Management Plan (Wyoming Department of Agriculture, 1995, p. 1A-3) is about $1 \mathrm{mg} / \mathrm{L}$. Ninety-five percent of all the samples in the Green and Snake River Basin had no detection of pesticides.

Streams naturally carry suspended sediment. However, increased concentrations of suspended sediment can be related to land use activities such as irrigation, grazing, logging, mining, recreation, and road construction. High concentrations of suspended sediment can cause (1) reduction in the aesthetic qualities of the water, (2) filling of reservoirs and other water bodies, (3) reduction of light penetration in water to the detriment of many species of aquatic life, (4) deposition of sediments on stream bottoms resulting in a loss of spawning habitat for many species of fish, and (5) sorption and transport of insoluble trace elements and organic compounds onto sediment. The highest median concentration of suspended sediment $(70 \mathrm{mg} / \mathrm{L})$ was observed in a water sample collected from the Bear River Basin.

A sampling event on the Salt River was conducted July 18-23, 1994, in cooperation with the Upper Snake River NAWQA. The Salt River was chosen for further study because of the potential for future development in the valley and the Wyoming State Engineer's interest in the impact of human activity on streamflow water quality. The Salt River flows north through the agriculturally based Star Valley in northwestern Lincoln County. The river enters the head of the valley approximately 5 miles south of Smoot (fig. 9) and flows north through "the Narrows" south of Thayne. The Narrows, which divides Star Valley into an upper and lower valley, is a short canyon formed by rock outcrops of the Tertiary Salt Lake Formation to the east and Triassic- and Jurassicage rocks to the west. The Salt River continues to flow north through the lower valley until it reaches Palisades Reservoir near Alpine.

Streamflow discharge was measured and water-quality samples were collected from 10 sites (fig. 9) on the Salt River and from one tributary site (Crow Creek at county road 143, near Fairview, site 143). Physical properties were measured onsite, and surface-water samples were collected for determination of major ions and nutrients at all sites. Fecal coliform levels were determined in water samples collected at 10 sites, and pesticide concentrations were determined in water samples collected at 6 sites. Water-quality samples were collected in July, after high flow and before low flow (table 13, at the back of report).

As the Salt River flows through Star Valley, the quality and quantity of the river is impacted by agriculture and geothermal activity. As the river flows through the valley, it gains water from tributaries, ground water, and a variety of surface-water returns, and loses water to ground water, surface-water diversions, and evapotran- 


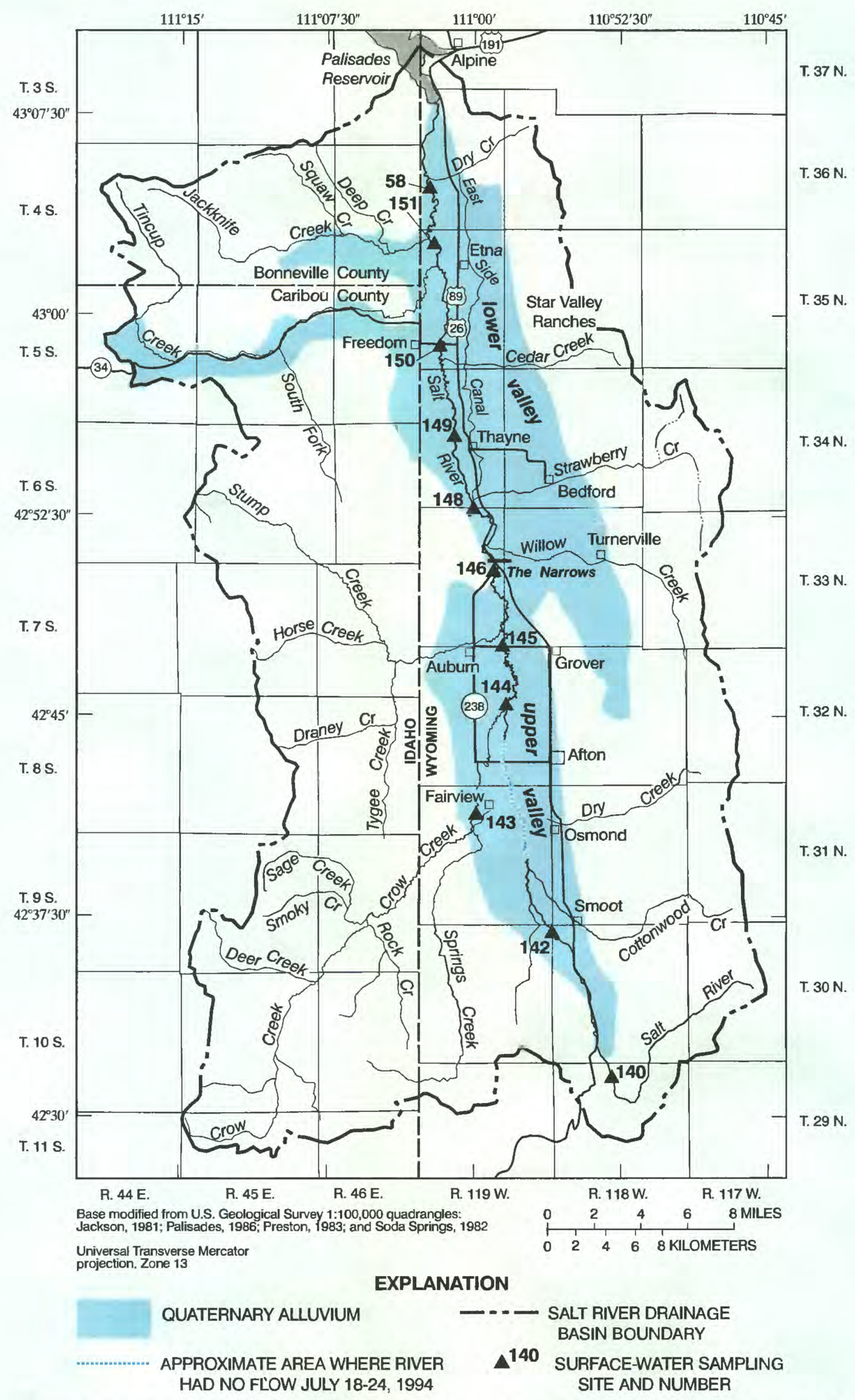

Figure 9. Location of streamflow data collection sites on the Salt River and a tributary to the Salt River sampled July 18-23, 1994. 
spiration. During the sampling event, the largest estimated streamflow loss was to East Side Canalapproximately $100 \mathrm{ft}^{3} / \mathrm{s}$ (table 13). Despite these losses, the Salt River gained approximately $340 \mathrm{ft}^{3} / \mathrm{s}$ from Salt River above Fish Creek, near Smoot (site 140) where the Salt River enters the upper valley to the site Salt River above reservoir near Etna (site 58) where the river discharges to Palisade Reservoir (table 13). Between Salt River at County Road 148, near Smoot (site 142) to just upstream of Salt River below Crow Creek near Afton (site 144), the Salt River was dry, in part because of the diversion of Salt River tributaries for irrigation.

Discharge from Crow Creek, $24 \mathrm{ft}^{3} / \mathrm{s}$, combined with ground-water inflow, increased the discharge in the Salt River to $64 \mathrm{ft}^{3} / \mathrm{s}$ at site 144 . Streamflow continued to increase from site 144 to the Narrows. The flow in the river is unchanged as it passes through the Narrows. The river loses about 40 percent of its streamflow to East Side Canal after the river exits the Narrows, but more than doubles its streamflow from the site below the East Side Canal, Salt River near Thayne (site 149) to site 58 above Palisades Reservoir. The gain in streamflow is likely from ground-water inflow and surface-water return flow.

Further study is needed to determine cause and effect relations from the water-quality data collected during the sampling event. However, some general observations can be made. Sulfate, chloride, and nitrate were evaluated in surface-water samples, because agricultural practices and geothermal activity can affect those water-quality constituents. Instantaneous discharge, physical and biological properties, and inorganic waterquality data collected during the study are compiled in table 13.

Just as streamflow discharge increased from the farthest upstream site to the farthest downstream in both the upper and lower valleys, so did loads of sulfate, chloride, and nitrate. The concentration, in comparison to the load, of the three chemicals did not always behave similarly in the same stretches of the river. Sulfate and chloride concentrations increased downstream in the upper valley and nitrate concentrations, in general, decreased. Conversely, sulfate and chloride concentrations decreased in the lower valley, and nitrate concentrations, in general, increased. The increased sulfate and chloride concentration and load in the upper valley may be related to geothermal ground-water inflow into the Salt River from the western side of the valley at the Narrows, rather than to an agricultural influence.

Four pesticides--2,4-D, picloram, EPTC, and dicamba--are used by the Lincoln County Weed and Pest Control (Scott Nield, oral commun., 1994). Surface-water samples collected during the study were analyzed for these 4 primary and 39 other pesticides at 6 sites (sites 142,144, 146, 149, 150, and 58) (fig 9). All pesticide concentrations were less than the minimum reporting limits established by NWQL (2,4-D, picloram, and dicamba reporting limits, $0.01 \mu \mathrm{g} / \mathrm{L}$; EPTC reporting limit, $0.005 \mu \mathrm{g} / \mathrm{L}$ ). Also, all pesticide concentrations were less than the reporting limit for a sample collected in May 1994 at site 58 for the Upper Snake River NAWQA.

\section{Ground-Water Quality}

Data describing the water quality of geologic units are obtained by collecting samples of ground water from wells completed in or from springs issuing from a specific geologic unit. The physical and chemical characteristics of ground water are related by the geologic units that water has been in contact with and to human activities (table 6). The physical and chemical characteristics for water samples consist of analyses of samples collected as part of this study of Lincoln County and historical data in the USGS ground-water and water-quality data bases. Ground-water samples collected during this study were analyzed at the NWQL for common ions (table 14, at the back of report), and selected samples were analyzed for select trace elements (table 15, at the back of report). Physical properties of specific conductance, $\mathrm{pH}$, and water temperature determined onsite also are listed in table 14.

Analyses of ground-water samples collected from wells completed in and springs issuing from deposits of Quaternary age, rocks of Tertiary age, and rocks from Mesozoic and Paleozoic age are included in this report. Analysis of a ground-water sample collected during the 1993-95 field season included onsite measurements of 
specific conductance, $\mathrm{pH}$, and temperature. At many sites, a water sample also was collected for chemical analyses at the NWQL. The distribution of dissolved-solids concentrations in water samples collected from geologic units in Lincoln County is shown in figure 10. Modified Stiff diagrams (fig. 11) represent the water type typically found in selected geologic units at various sites in the county. Box plots (fig. 10) and modified Stiff diagrams (fig. 11) were constructed for geologic units containing five or more sites where ground-water samples were collected. When a site had two or more samples analyzed, the total dissolved-solids concentrations were averaged for box plot and modified Stiff diagrams construction. Modified Stiff diagrams were constructed by determining the median value of each constituent from the geologic unit, then selecting an actual site that most closely represented the median values. With the exception of the Preuss Sandstone or Preuss Redbeds, where three sites were sampled, only geologic units with five or more sites where water samples were collected for chemical analyses are described in detail in each section.

\section{Quaternary Deposits}

Ninety-six ground-water samples were collected for chemical analysis and 30 water samples were collected for onsite analysis from 118 sites during this and previous studies from wells completed in and springs issuing from deposits of Quaternary age (table 14). An additional 74 samples (in table 16, at the back of report) were collected from monitoring wells in Star Valley, and are discussed in the Star Valley Monitoring Well Section. Ground-water samples were collected for chemical analysis from the alluvium and colluvium (82), glacial deposits (1), landslide deposits (4), and terrace deposits (9). Quaternary alluvial and colluvial and terrace deposits are located near major streams and rivers throughout Lincoln County (fig. 12). The chemical characteristics of water samples collected from alluvium and colluvium, and terrace deposits are described in the following section.

Eighty-two ground-water samples (plus the additional 74 from the Star Valley Monitoring Wells) were collected for chemical analysis from 76 wells completed in and 2 springs issuing from the alluvium and colluvium. The samples were collected from wells completed in and springs issuing from the alluvium and colluvium located along the following stream and river systems: the Salt River, the Bear River, the Green River, and Hams Fork. Dissolved-solids concentrations in water samples collected from the alluvium and colluvium ranged from 196 to 3,090 $\mathrm{mg} / \mathrm{L}$ (table 14). Water types of the samples from the alluvium and colluvium differed from the shaley Tertiary parent material of the alluvium and colluvium. This material is different from the parent material of the alluvium and colluvium of the Salt and Bear Rivers, which does not contain much shale; therefore, the water from the Salt and Bear River alluvium and colluvium contains lower dissolved-solids concentrations. Water samples from 64 wells were analyzed for specific trace elements; dissolved concentrations are listed in table 15. The iron concentrations of samples collected from the alluvium and colluvium ranged from less than the method reporting limit $(3 \mu \mathrm{g} / \mathrm{L})$ to $1,200 \mu \mathrm{g} / \mathrm{L}$ (table 15 ).

Nine ground-water samples were collected for chemical analysis from six wells completed in and three springs issuing from the terrace deposits. Dissolved-solids concentrations of samples from terrace deposits ranged from 231 to $1,010 \mathrm{mg} / \mathrm{L}$. The modified Stiff diagram shows a calcium carbonate water type, with a typical dissolved-solids concentration of $351 \mathrm{mg} / \mathrm{L}$ (fig. 11).

\section{Tertiary Rocks}

Sixty-eight ground-water samples were collected for chemical analysis and 18 ground-water samples were collected for onsite analysis only from 74 sites during this and previous studies from wells completed in and springs issuing from rocks of Tertiary age. Samples collected from Tertiary rocks in Lincoln County are from sites located mainly in the southern half of the county, with the exception of the Salt Lake and Teewinot Formations near Star Valley (fig. 12). Samples were collected for chemical analysis from undifferentiated Tertiary rocks (4), the Salt Lake and Teewinot Formations (7), the Bridger Formation (2), and the Fowkes 


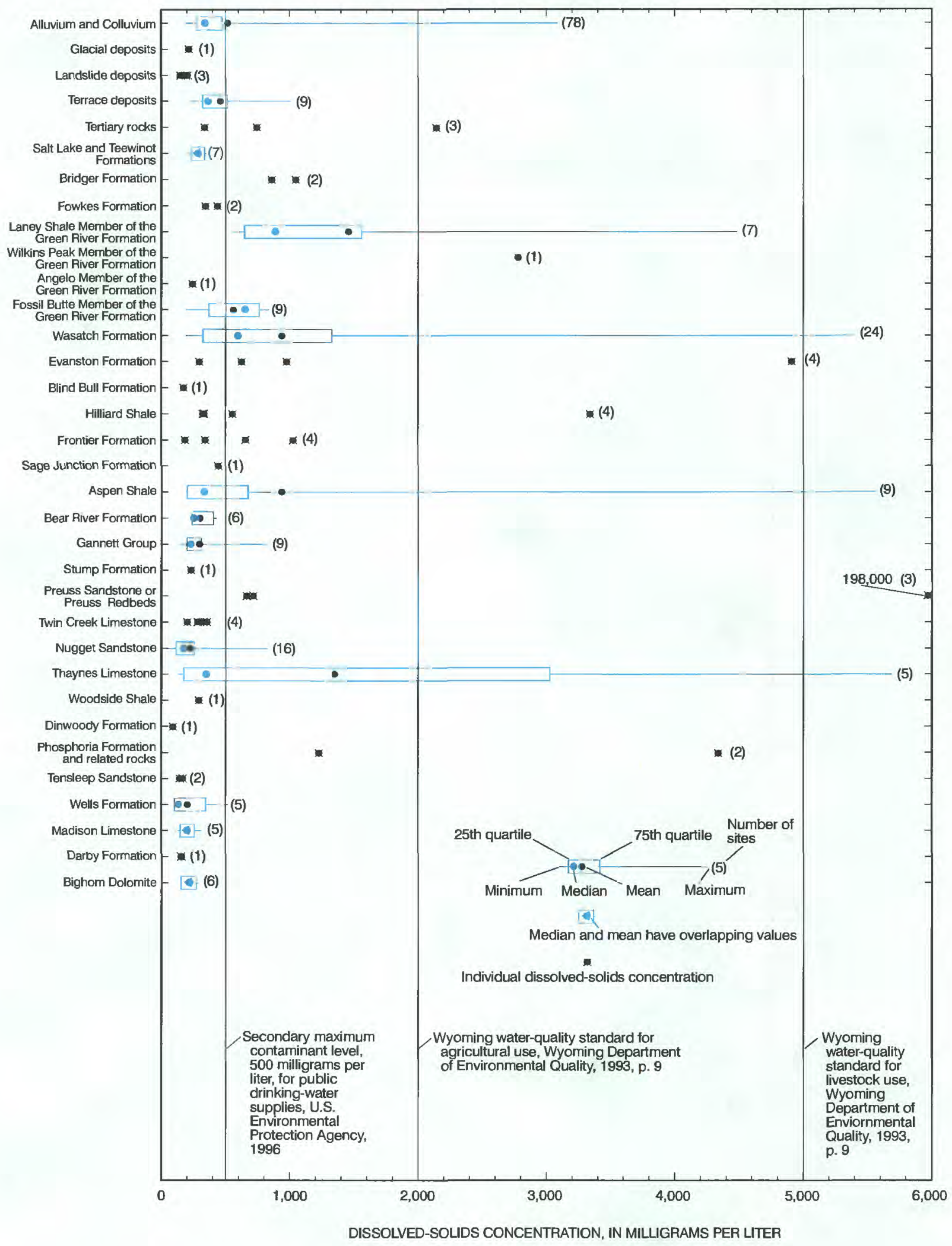

Figure 10. Distribution of dissolved-solids concentrations in water samples collected from wells completed in and springs from selected geologic units in Lincoln County, Wyoming. 

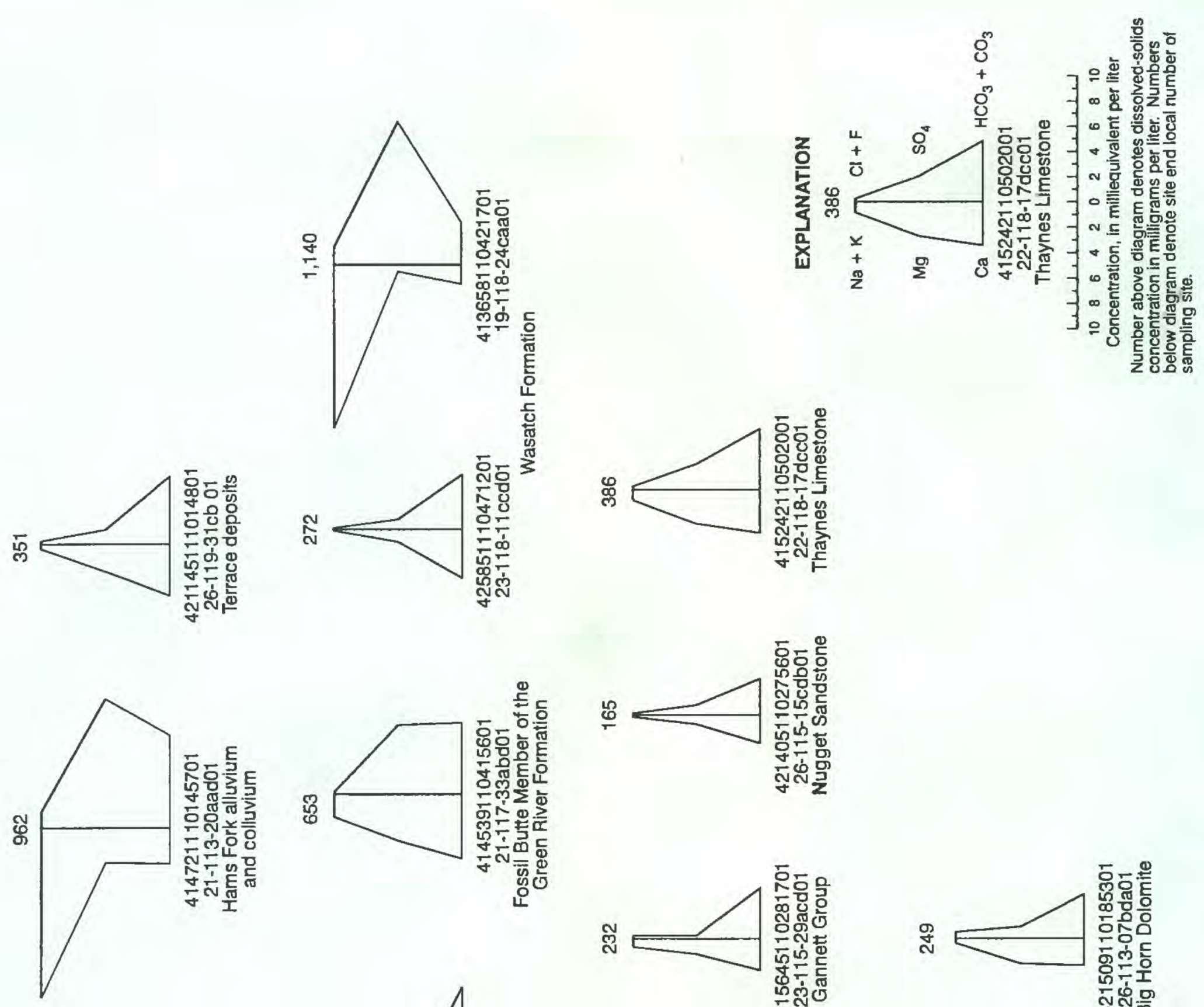

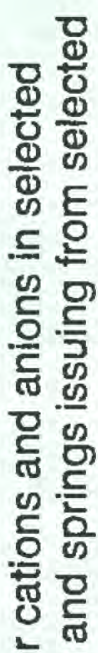
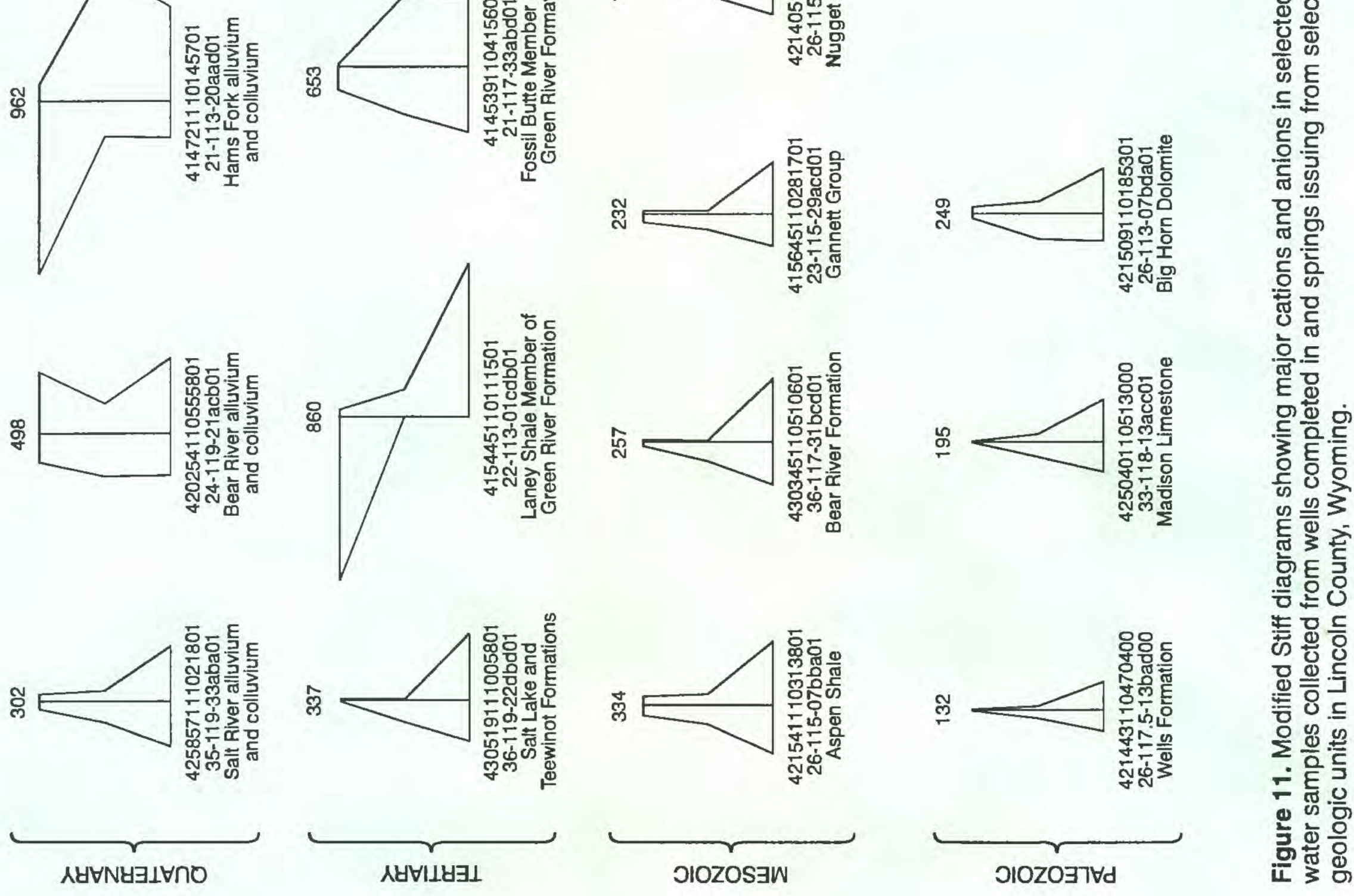


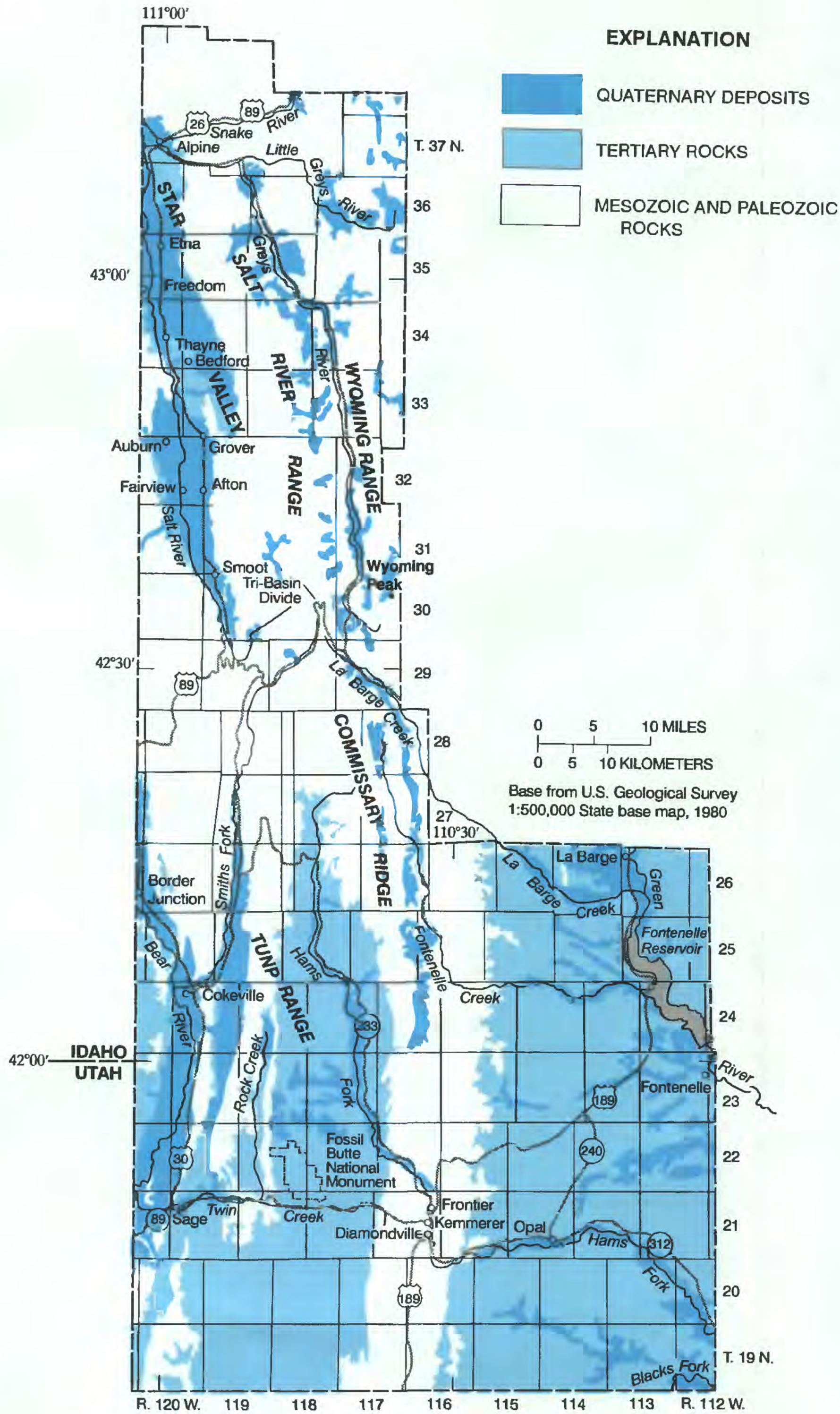

Figure 12. General location of Quaternary deposits, Tertiary rocks, and Mesozoic and Paleozoic rocks in Lincoln County, Wyoming. 
Formation (2). Samples were collected from members of the Green River Formation and include, specifically, the Laney Member (10), the Wilkins Peak Member (1), the Angelo Member (1), and the Fossil Butte Member (10). Twenty-seven samples were collected from the Wasatch Formation, and four samples were collected from the Evanston Formation. The chemical characteristics of the water samples collected from the Salt Lake and Teewinot Formations, the Laney and Fossil Butte Members of the Green River Formation, and the Wasatch Formation are described. Forty-four water samples collected from Tertiary rocks were analyzed for trace elements (table 15). Samples from the Wilkins Peak Member of the Green River Formation contained the highest concentration of boron $(4,200 \mu \mathrm{g} / \mathrm{L})$ (table 15). Samples from the Wasatch Formation contained the highest concentration of iron $(1,600 \mu \mathrm{g} / \mathrm{L})($ table 15$)$.

As previously mentioned, the Salt Lake and Teewinot Formations are not differentiated. Seven groundwater samples were collected for chemical analysis from four wells completed in and three springs issuing from the Salt Lake and Teewinot Formations. All samples were collected in the northwestern part of the county near Star Valley. The dissolved-solids concentrations ranged from 206 to $349 \mathrm{mg} / \mathrm{L}$ (table 14). The modified Stiff diagram shows a calcium carbonate water type, with a typical dissolved-solids concentration of $337 \mathrm{mg} / \mathrm{L}$ (fig. 11).

Two members of the Green River Formation, the Laney and Fossil Butte Members, were sampled frequently enough to discuss. These two members are quite different with respect to dissolved-solids concentration and water type. This difference may, in part, be due to the location where ground water from these units was sampled. Water from the Laney Member typically was sampled from wells in the central part of the Green River Basin. Ten ground-water samples were collected for chemical analysis from six wells completed in and one spring issuing from the Laney. The dissolved-solids concentrations ranged from 551 to $4,480 \mathrm{mg} / \mathrm{L}$ (table 14). All water samples collected from the Laney Member had a dissolved-solids concentration greater than the SMCL of $500 \mathrm{mg} / \mathrm{L}$ established by the USEPA, (table 8 ). The modified Stiff diagram shows a sodium carbonate water type with a typical dissolved-solids concentration of $860 \mathrm{mg} / \mathrm{L}$ (fig. 11). The water producing zone in the Fossil Butte Member was a limestone or marlstone layer nearer to the recharge area on the western edge of the Green River Basin. Ten samples were collected for analysis from nine springs issuing from the Fossil Butte Member. The dissolved-solids concentrations of these samples ranged from 193 to $836 \mathrm{mg} / \mathrm{L}$ (table 14). The modified Stiff diagram shows a calcium sulfate-carbonate water type with a typical dissolvedsolids concentration of $653 \mathrm{mg} / \mathrm{L}$ (fig. 11).

Twenty-seven ground-water samples were collected for chemical analysis from 10 wells completed in and 16 springs issuing from the Wasatch Formation. The dissolved-solids concentration ranged from 194 to $5,400 \mathrm{mg} / \mathrm{L}$ (table 14). The modified Stiff diagrams indicate two different water types associated with the Wasatch Formation in Lincoln County. Samples collected from springs near the recharge area are influenced more from snow melt and had a calcium carbonate water type with a typical dissolved-solids concentration of $272 \mathrm{mg} / \mathrm{L}$ (fig. 11, site 425851110471201). Samples collected from wells or springs farther away from the recharge area were less influenced from snow melt, and had a sodium sulfate water type with a typical dissolvedsolids concentration of $1,140 \mathrm{mg} / \mathrm{L}$ (fig. 11, site 413658110421701 ).

\section{Mesozoic Rocks}

Seventy-eight ground-water samples were collected for chemical analysis and 28 water samples were collected for onsite analysis only from 82 sites during this and previous studies from wells completed in and springs issuing from rocks of Mesozoic age. Mesozoic rocks from which water samples were collected are located in a north-south direction through the center of Lincoln County (fig. 12). This means that samples collected from one formation, for example the Gannett Group, may be 75-100 miles away from another sample 
collection site from the same formation. Water samples were collected for chemical analysis from the Blind Bull Formation (1), the Hilliard Shale (4), the Frontier Formation (5), the Sage Junction Formation (1), the Aspen Shale (13), the Bear River Formation (9), and the Gannett Group (11), all of Cretaceous age; the Stump Formation (1), the Preuss Sandstone or Preuss Redbeds (3), and the Twin Creek Limestone (4) of Jurassic age; the Nugget Sandstone (18) of Jurassic(?) and Triassic(?) age; and the Thaynes Limestone (6), the Woodside Shale (1), and the Dinwoody Formation (1) of Triassic age. The chemical characteristics of the water samples collected from the Aspen Shale, the Bear River Formation, the Gannett Group, the Preuss Sandstone or Preuss Redbeds, the Nugget Sandstone, and the Thaynes Limestone are described in this section.

Thirteen ground-water samples were collected for chemical analysis from one well completed in and eight springs issuing from the Aspen Shale. The dissolved-solids concentrations ranged from 192 to $5,570 \mathrm{mg} / \mathrm{L}$ (table 14). The dissolved-solids concentrations in the Aspen Shale are dependent on the time of year when samples are collected, as well as the amount of recharge that has occurred from infiltration of recent precipitation. The modified Stiff diagram shows a calcium carbonate water type, with a typical dissolved-solids concentration of $334 \mathrm{mg} / \mathrm{L}$ (fig. 11).

Nine ground-water samples were collected for chemical analysis from one well completed in and five springs issuing from the Bear River Formation. The dissolved-solids concentrations ranged from 226 to $505 \mathrm{mg} / \mathrm{L}$ (table 14). The modified Stiff diagram shows a calcium carbonate water type, with a typical dissolved-solids concentration of $257 \mathrm{mg} / \mathrm{L}$ (fig. 11).

Eleven ground-water samples were collected for chemical analysis from nine springs issuing from the Gannett Group. The dissolved-solids concentrations ranged from 137 to $824 \mathrm{mg} / \mathrm{L}$ (table 14). The Gannett Group spans a large area of the county; however, the dissolved-solids concentrations do not differ substantially from the northern to the southern end of the county. The modified Stiff diagram shows a calcium carbonate water type, with a typical dissolved-solids concentration of $232 \mathrm{mg} / \mathrm{L}$ (fig. 11).

Three ground-water samples were collected for chemical analysis from three springs issuing from the Preuss Sandstone or Preuss Redbeds. Although there were not enough samples collected to prepare a box plot or a modified Stiff diagram, one sample had a sodium concentration of $120,000 \mathrm{mg} / \mathrm{L}$, a chloride concentration of $75,000 \mathrm{mg} / \mathrm{L}$, and a dissolved-solids concentration of $198,000 \mathrm{mg} / \mathrm{L}$ (table 14 ). This sample was collected from a spring (site 422802110575901 ) that probably issues from one of the irregular halite deposits noted in Oriel and Platt (1980), and is probably not an indicator of the general water quality found in the Preuss Sandstone or Preuss Redbeds.

Eighteen ground-water samples were collected for chemical analysis from 1 well completed in and 15 springs issuing from the Nugget Formation. All springs in the Nugget Formation sampled during this study discharged through fractures. Fractures (secondary permeability) are prominent in the Nugget, thus the residence time of water in the formation is short when compared to the residence time of water movement from primary permeability. This short residence time generally results in low dissolved-solids concentrations. The dissolved-solids concentrations ranged from 40 to $824 \mathrm{mg} / \mathrm{L}$ (table 14). The modified Stiff diagram shows a calcium carbonate water type, with a typical dissolved-solids concentration of $165 \mathrm{mg} / \mathrm{L}$ (fig. 11 ).

Six ground-water samples were collected for chemical analysis from one well completed in and four springs issuing from the Thaynes Limestone. The dissolved-solids concentrations ranged from 128 to $5,690 \mathrm{mg} / \mathrm{L}$ (table 14); however, most samples had dissolved-solids concentrations less than $400 \mathrm{mg} / \mathrm{L}$. The modified Stiff diagram shows a calcium-magnesium carbonate water type, with a typical dissolved-solids concentration of $386 \mathrm{mg} / \mathrm{L}$ (fig. 11). 


\section{Paleozoic Rocks}

Twenty-nine ground-water samples were collected for chemical analysis and 2 ground-water samples were collected for onsite analysis only from 21 sites during this and previous studies from wells completed in and springs issuing from rocks of Paleozoic age. Paleozoic rocks in Lincoln County are exposed in a northsouth trending alignment through the center of the county, similar to the rocks of Mesozoic age (fig. 12). Water samples were collected for chemical analysis from the Phosphoria Formation and related rocks of Permian age (2); the Tensleep Sandstone (3), and the Wells Formation (7) of Pennsylvania age; the Madison Limestone of Mississippian age (7); the Darby Formation of Devonian age (1); and the Bighorn Dolomite of Ordovician age (9). As a group, water samples collected from Paleozoic rocks have the lowest dissolved-solids concentrations of water samples from all geologic units in Lincoln County. Water from springs issuing from Paleozoic rocks is used as a water supply for several towns and water districts in Star Valley. The chemical characteristics of the water samples collected from the Wells Formation, the Madison Limestone, and the Bighorn Dolomite are described in the following section.

Seven ground-water samples were collected for chemical analysis from one well completed in and four springs issuing from the Wells Formation. The dissolved-solids concentrations ranged from 100 to $521 \mathrm{mg} / \mathrm{L}$ (table 14). The modified Stiff diagram shows a calcium carbonate water type, with a typical dissolved-solids concentration of $132 \mathrm{mg} / \mathrm{L}$ (fig. 11).

Seven ground-water samples were collected for chemical analysis from five springs issuing from the Madison Limestone. The dissolved-solids concentrations ranged from 104 to $311 \mathrm{mg} / \mathrm{L}$ (table 14). The modified Stiff diagram shows a calcium carbonate water type, with a typical dissolved-solids concentration of $195 \mathrm{mg} / \mathrm{L}$ (fig. 11).

Nine ground-water samples were collected for chemical analysis from six springs issuing from the Bighorn Dolomite. The dissolved-solids concentrations ranged from 153 to $294 \mathrm{mg} / \mathrm{L}$ (table 14). The modified Stiff diagram shows a calcium-magnesium carbonate water type, with a typical dissolved-solids concentration of $249 \mathrm{mg} / \mathrm{L}$ (fig. 11).

\section{GROUND-WATER MONITORING IN STAR VALLEY}

Increased population growth and recent detections of nitrate concentrations greater than the MCL (10 mg/L as nitrogen) (Ken Mills, Natural Resource Conservation Service, oral commun., 1993) in Star Valley prompted a study of the baseline water quality of the ground water. The baseline data are used to determine the general water quality of the aquifer at the present time. Data from the study was also used to answer the following two questions: (1) do nitrate concentrations vary seasonally, and (2) do nitrate concentrations correlate with the depth to ground water at the time of sampling. Answers to these questions will enhance analysis of past data, as well as assist with the design of future sampling efforts.

Ten domestic wells completed in the Salt River alluvium and colluvium were selected and established as monitoring wells in 1993 (fig. 13). This work was supported, in part, by the Star Valley Conservation District. The wells selected were distributed throughout the valley, and were located away from any potential nitrate source such as a confined animal feeding operation. The wells were sampled four times per year, once each season (fall, winter, spring, and summer), from October 1993 through July 1995, for a total of eight sampling events (table 16, at the back of report). 


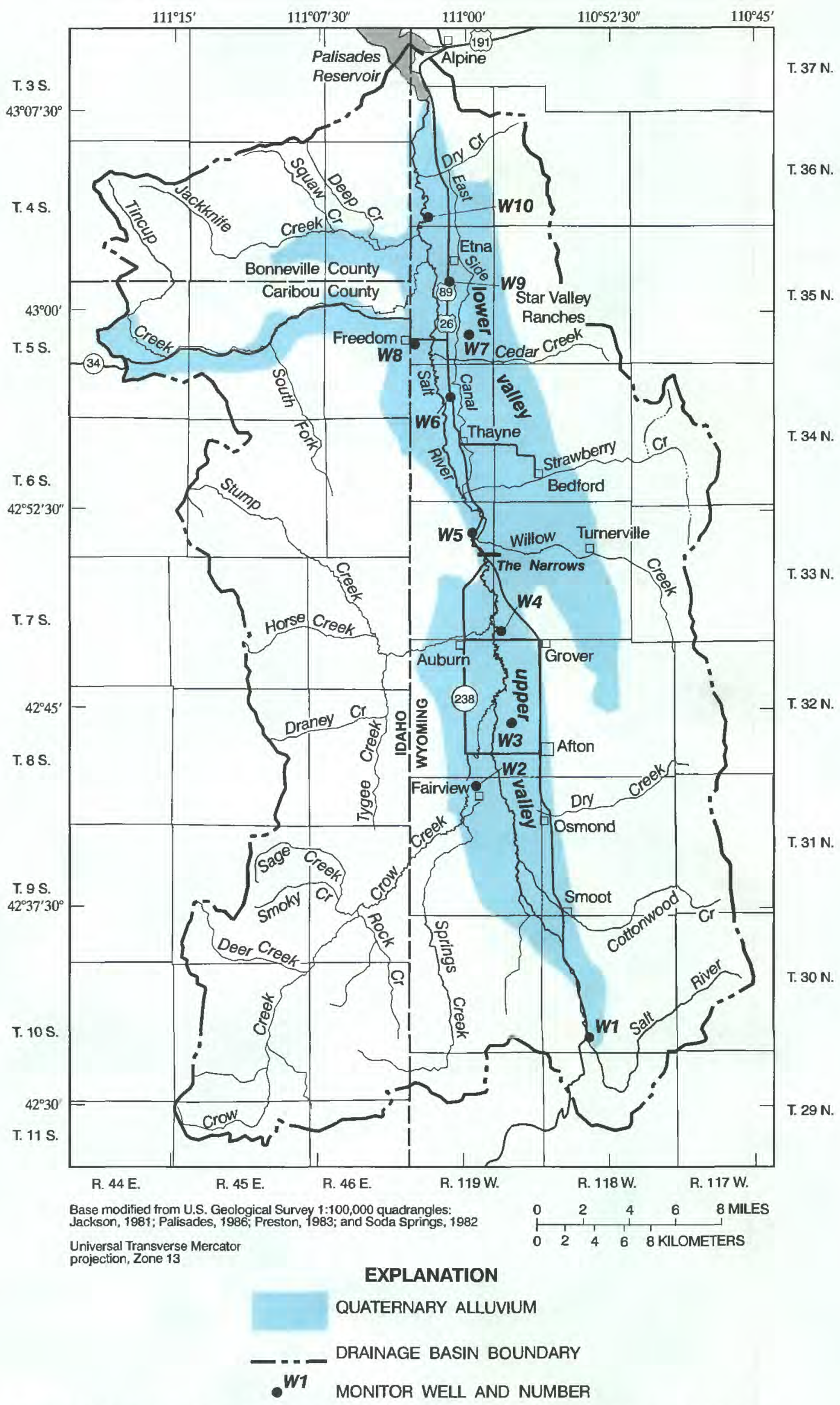

Figure 13. Location of wells used in the Star Valley monitoring study, Idaho and Wyoming. 
A total of 84 ground-water samples were collected from the wells used in the Star Valley monitoring study (table 16). No water sample had a nitrate concentration greater than the MCL. The nitrate concentrations in the 10 wells had slightly different ranges during each season (table 10 ). The widest range was $3.6 \mathrm{mg} / \mathrm{L}$ as nitrogen $(0.1$ to 3.7$)$ in the winter, and the narrowest range was $2.7 \mathrm{mg} / \mathrm{L}$ as nitrogen $(0.2$ to 2.9$)$ in the spring. However, statistical analysis indicated there was no significant difference between the data collected in the different seasons. The data from the ground-water wells in the valley, as a whole, did not show a statistical correlation between the depth to the ground water and the nitrate concentration. Three of the 10 wells showed some relation between the depth to the ground water and the nitrate concentration; however, the differences in nitrate concentrations in the water samples over the sampling period were small, and are more likely because of sampling and analytical inaccuracies, than a true change in the water.

Table 10. Statistical summary of seasonal nitrite plus nitrate data from ground-water samples collected during the Star Valley monitoring study, 1993-95, Lincoln County, Wyoming

[Analytical results in milligrams per liter as nitrogen]

\begin{tabular}{lcccc}
\hline \multicolumn{1}{c}{ Season } & $\begin{array}{c}\text { Minimum } \\
\text { nitrite + nitrate } \\
\text { concentration }\end{array}$ & $\begin{array}{c}\text { Maximum } \\
\text { nitrite + nitrate } \\
\text { concentration }\end{array}$ & $\begin{array}{c}\text { Mean } \\
\text { nitrite + nitrate } \\
\text { concentration }\end{array}$ & $\begin{array}{c}\text { Median } \\
\text { nitrite + nitrate } \\
\text { concentration }\end{array}$ \\
\hline Winter (early March) & 0.1 & 3.7 & 1.2 & 0.9 \\
Spring (mid May) & .2 & 2.9 & 1.2 & .9 \\
Summer (late July) & .3 & 3.2 & 1.3 & 1.0 \\
Fall (early October) & .2 & 3.5 & 1.4 & 1.2 \\
\hline
\end{tabular}

\section{SUMMARY AND CONCLUSIONS}

Surface-water, ground-water, and water-quality data were compiled to describe and evaluate the water resources of Lincoln County, Wyoming. Streams in the county are classified as ephemeral/intermittent or perennial. Ephemeral/intermittent streams, which originate in the High Desert Region in the southeastern and southwestern parts of the county, are characterized by extended periods of no flow. Perennial streams, which originate in the Mountainous Region in the northern and central parts of the county, have sustained streamflow as a result of infiltration of precipitation, low evapotranspiration, and ground-water storage.

The average annual runoff varied for the two hydrologic regions that occur in Lincoln County. In the Mountainous Region, average annual runoff ranged from 1.05 to 40 inches per year. Although, no streamflowgaging stations in the county were identified as receiving most of their flow from the High Desert Region, this type of stream does exist in the county. At a gaging station located 40 miles east of the county in the High Desert Region, the average annual runoff was 0.1 inch per year.

Geologic units were grouped mainly by age, and include deposits of Quaternary age, and rocks of Tertiary, Mesozoic, and Paleozoic age. Rocks of Precambrian age are not exposed at the surface in Lincoln County. Quaternary deposits had the most water development of any geologic unit in the county. The most productive alluvial and colluvial aquifers in the Overthrust Belt, with pumping wells discharging up to 2,000 gal $/ \mathrm{min}$, are located in the valleys of the Bear River and Salt River (Star Valley). Wells completed in and springs issuing 
from other geologic units inventoried during this study with discharges greater than 500 gallons per minute included: the landslide deposits of Quaternary age, the Salt Lake and Teewinot Formations, and Evanston Formation of Tertiary age, the Gannett Group of Cretaceous age, the Nugget Sandstone of Jurassic(?) and Triassic(?) age, the Wells Formation of Permian and Pennsylvanian age, the Madison Limestone of Mississippian age, and the Bighorn Dolomite of Ordovician age.

Ground-water movement is related to the location of recharge and discharge areas and to the thickness and permeability of the aquifer material. The ground-water connection between areas in the Overthrust Belt and the Green River Basin is restricted by folded and faulted rocks, which are a result of regional tectonic (or orogenic (mountain building)) activity that extended from the middle Mesozoic to the early Cenozoic time. Ground-water movement is difficult to define by aquifer within the Overthrust Belt because of the numerous faults and fractures. Aquifers of Paleozoic and Mesozoic age in the Overthrust Belt primarily receive recharge from direct infiltration of precipitation in outcrop areas. Most of the water discharged from major Paleozoic limestone and dolomite aquifers (including the Madison Limestone of Mississippian age, Darby Formation of Devonian age, and the Bighorn Dolomite of Ordovician age) in the Overthrust Belt is through large springs. Water recharging these aquifers in one surface drainage basin may discharge in another drainage basin via interbasin transfers of ground water.

Total water use in Lincoln County in 1993 was estimated to be 405,000 million gallons. Surface water was the source for about 98 percent of the water used in the county; ground water only accounted for about 2 percent of the water used. Hydroelectric power generation and irrigation used the largest amount of water. Public supply and self-supplied domestic use accounted for 0.5 percent of the water used in Lincoln County. The sources of water for most public supplies in the county are wells and springs. An exception is the Kemmerer and Diamondville municipal system, which withdraws surface water from the Hams Fork River. Self-supplied domestic water is water withdrawn from a water source by a user rather than a public supplier. The source of water for self-supplied domestic water in the county is primarily ground water.

Discharge measurements and surface-water samples were collected from the Salt River and one tributary to the Salt River during a streamflow sampling event in Star Valley, July 18-23, 1994. During that time, the river had an overall gain of 340 cubic feet per second along the reach from the Salt River's entrance into Star Valley to the end of the valley where the river discharges into the Palisades Reservoir.

Dissolved-solids concentrations varied greatly for ground-water samples collected from 35 geologic units. Dissolved-solids concentrations in all water samples collected from the Laney Member of the Green River Formation of Tertiary age were greater than the Secondary Maximum Contaminant Level of 500 milligrams per liter established by the U.S. Environmental Protection Agency. All ground-water samples collected from the Salt Lake and Teewinot Formations of Tertiary age, the Madison Limestone of Mississippian age, and the Bighorn Dolomite of Ordovician age contained dissolved-solids concentrations less than the Secondary Maximum Contaminant Level.

Increased population growth in Star Valley and recent detections of nitrate concentrations above the maximum contaminant level of $10 \mathrm{mg} / \mathrm{L}$ as nitrogen, established by the U.S. Environmental Protection Agency, prompted a study of the baseline water quality of the ground water. Ten domestic wells completed in the Salt River alluvium and colluvium were established as monitoring wells in 1993. A total of 84 ground-water samples were collected from the wells used in the Star Valley monitoring study. No water sample had a nitrate concentration greater than the maximum contaminant level. Statistical analysis indicated there was no significant difference between the water quality data collected in different seasons, and no correlation between the nitrate concentrations and the depth to ground water. 


\section{REFERENCES}

Ahern, J., Collentine, M., and Cooke, S., 1981, Occurrence and characteristics of ground water in the Green River Basin and Overthrust Belt, Wyoming: Laramie, Wyo., Water Resources Research Institute, University of Wyoming, $123 \mathrm{p}$.

Bear River Commission, Biennial Reports: Bountiful, Utah, Bear River Commission.

Benson, M.A., and Dalrymple, Tate, 1967, General field and office procedures for indirect discharge measurements: U.S. Geological Survey Techniques of Water-Resources Investigations, Book 3, Chap. A1, 30 p.

Berry, Delmar W., 1955, Reconnaissance of the geology and ground-water resources of the Cokeville area, Lincoln County, Wyoming: U.S. Geological Survey Open-File Report (not numbered), 11 p.

Blanchard, Mark R., 1990, Discrimination between flow-through and pulse-through components of an alpine carbonate aquifer, Salt River Range, Wyoming: Laramie, Wyo., University of Wyoming, Master's thesis, 77 p.

Clark, Gregory M., 1994, Assessment of selected constituents in surface water of the upper Snake River Basin, Idaho and western Wyoming, water years 1975-89: U.S. Geological Survey Water-Resources Investigations Report 93-4229, $49 \mathrm{p}$.

Corsi, Elma W., 1990, The hills of home: Afton, Wyo., Afton Thrifty Print, 361 p.

DeLong, Lewis L., 1977, An analysis of salinity in streams of the Green River Basin, Wyoming: U.S. Geological Survey Water-Resources Investigations 77-103, 32 p.

1986, Water quality of streams and springs, Green River Basin, Wyoming: U.S. Geological Survey Water-Resources Investigations Report 82-4008, 36 p.

DeLong, L. L., and Wells, D. K., 1988, Estimating average dissolved-solids yield from basins drained by ephemeral and intermittent streams--Green River Basin, Wyoming: U.S. Geological Survey Water-Resources Investigations Report 87-4222, 14 p.

Freethey, G.W., and Cordy, G.E., 1991, Geohydrology of Mesozoic rocks in the upper Colorado River Basin in Arizona, Colorado, New Mexico, Utah, and Wyoming, excluding the San Juan Basin: U.S. Geological Survey Professional Paper 1411-C, $117 \mathrm{p}$.

Freeze, R.A., and Cherry, J.A., 1979, Groundwater: Englewood Cliffs, N.J., Prentice-Hall, Inc., 604 p.

Hem, John D., 1985, Study and interpretation of the chemical characteristics of natural water: U.S. Geological Survey Water-Supply Paper 2254, 263 p.

Lane, Dana W., 1973, The Phosphoria and Goose Egg Formations in Wyoming: Laramie, Wyo., Wyoming Geological Survey Preliminary Report no. 12, p. 1-24.

Larson, L.R., 1985, Dissolved solids, in Lowham, H.W., and others, Hydrology of area 52, Rocky Mountain coal province, Wyoming, Colorado, Idaho, and Utah: U.S. Geological Survey Water-Resources Investigations Open-File Report 83-761, p. $42-43$.

Lickus, M.R., and Law, B.E., 1988, Structure contour map of the greater Green River Basin, Wyoming, Colorado, and Utah: U.S. Geological Survey Miscellaneous Field Studies Map, 1 sheet.

Lines, G.C., and Glass W.R., 1975, Water resources of the Thrust Belt of western Wyoming: U.S. Geological Survey Hydrologic Investigations Atlas HA-539, 3 sheets.

Lowham, H.W., 1985, Surface-water quantity, in Lowham, H.W., and others, Hydrology of area 52, Rocky Mountain coal province, Wyoming, Colorado, Idaho, and Utah: U.S. Geological Survey Water-Resources Investigations Open-File Report 83-761, p. 32-39.

1988, Streamflows in Wyoming: U.S. Geological Survey Water-Resources Investigations Report 88-4045, 78 p.

Love, J.D., and Christiansen A.C., 1985, Geologic map of Wyoming: U.S. Geological Survey, scale 1:500,000, 3 sheets. 
Love, J.D., Christiansen A.C., and Ver Ploeg, A.J., 1993, Stratigraphic chart showing Phanerozoic nomenclature for the state of Wyoming: Laramie, Wyo., Geological Survey of Wyoming Map Series 41, 1 sheet.

Martner, B. E., 1986, Wyoming climate atlas: Lincoln, Nebr., University of Nebraska Press, 432 p.

M'Gonigle, J.W., and Dover, J.H., 1992, Geologic map of the Kemmerer 30'x 60' Quadrangle, Lincoln, Uinta, and Sweetwater Counties, Wyoming: U.S. Geological Survey Miscellaneous Investigations Series, Map I-2079, 1 sheet.

Ogle, Kathy Muller, Eddy-Miller, C.A., and Busing, C.J., 1996, Estimated use of water in Lincoln County, Wyoming in 1993: U.S. Geological Survey Water-Resources Investigations Report 96-4162, 11 p.

Oriel, S.S. and Platt, L.B., 1980, Geologic map of the Preston $1^{\circ} \times 2^{\circ}$ Quadrangle, southeastern Idaho and western Wyoming: U.S. Geological Survey Miscellaneous Investigations Series, Map I-1127, 1 sheet.

Oriel S.S. and Tracey, J.I., Jr., 1970, Uppermost Cretaceous and Tertiary stratigraphy of Fossil Basin, southwestern Wyoming: U.S. Geological Survey Professional Paper 635, 53 p.

Peterson, David A., 1988, Streamflow characteristics of the Green, Bear, and Snake River Basins, Wyoming, through 1984: U.S. Geological Survey Water-Resources Investigations Report 87-4022, 223 p.

Popkin, B.P., 1973, Ground-water resources of Hall and eastern Briscoe Counties, Texas: Texas Water Development Board Report 167, 85 p.

Rankl, James G., 1987, Average flow, in Peterson, D.A., and others, Hydrology of area 51, Northern Great Plains and Rocky Mountain coal provinces, Wyoming and Montana: U.S. Geological Survey Water-Resources Investigations Open-File Report 84-734, p. 30-31.

Ringen, Bruce H., 1984, Relationship of suspended sediment to streamflow in the Green River Basin, Wyoming: U.S. Geological Survey Water-Resources Investigations Report 84-4026, 13 p.

Roehler, H. W., 1992, Introduction to greater Green River Basin geology, physiography, and history of investigations: U.S. Geological Survey Professional Paper 1506-A, 12 p.

Schuetz, J.R., Ritz, G.F., Smalley, M.L., and Woodruff, R.E., 1995, Water resources data, Wyoming, Water Year 1994 : U.S. Geological Survey Water-Data Report WY-94-1, 363 p.

Searcy, J.K., 1959, Flow-duration curves: U.S. Geological Survey Water-Supply Paper 1542-A, 33 p.

U.S. Environmental Protection Agency, 1991, Secondary maximum contaminant levels (section 143.3 of part 143, National secondary drinking-water regulations): U.S. Code of Federal Regulations, Title 40, Parts 100 to 149, revised as of July $1,1991,759 \mathrm{p}$.

1996, Drinking water regulations and health advisories, Washington D.C., U.S. Environmental Protection Agency Report EPA 822-R-96-001,

U.S. Geological Survey, 1971, Index of surface-water records to September 30, 1970, Part 10--The Great Basin: U.S. Geological Survey Circular 660, 39 p.

Walker, E.H., 1965, Ground water in the upper Star Valley, Wyoming: U.S. Geological Survey Water-Supply Paper 1809$\mathrm{C}, 27 \mathrm{p}$.

Welder, George E., 1968, Ground-water reconnaissance of the Green River Basin, southwestern Wyoming: U.S. Geological Survey Hydrologic Investigations Atlas HA-290, 3 sheets.

Wyoming Department of Administration and Fiscal Control, Research and Statistics Division, 1991, 1991 Wyoming data handbook: Cheyenne, Wyo., 265 p.

Wyoming Department of Agriculture, 1995, Generic state management plan for pesticides in ground water for the state of Wyoming: Cheyenne, Wyo., prepared for the U.S. Environmental Protection Agency by the Ground-water and Pesticide Strategy Committee, variable pagination. 
Wyoming Department of Environmental Quality, 1993, Quality standards for groundwaters of Wyoming: Wyoming Department of Environmental Quality, Chap. VIII, 87 p.

Wyoming Historical Records Survey, 1941, Inventory of county archives of Wyoming, No.12, Lincoln County (Kemmerer): $166 \mathrm{p}$.

Wyoming State Engineer's Office, 1995, Ground water computer data base, September 1995: Cheyenne, Wyo., Wyoming State Engineer. 


\section{GLOSSARY}

AQUIFER. A body of rock that contains sufficient saturated permeable material to yield significant quantities of water to wells and springs.

ARTESIAN AQUIFER. Synonymous with confined aquifer.

ARTESIAN WELL. A well deriving its water from an artesian or confined aquifer in which the water level stands above the top of the aquifer.

COMMERCIAL WATER USE. Water for motels, hotels, restaurants, office buildings, and other commercial facilities, and institutions, both civilian and military. The water may be obtained from a public supply or may be self-supplied.

CONFINED AQUIFER. An aquifer bounded above and below by impermeable beds or by beds of distinctly lower permeability than that of the aquifer itself; an aquifer containing confined ground water.

CONFINING BED. A body of impermeable or distinctly less permeable material stratigraphically adjacent to one or more aquifers.

CONSUMPTIVE USE. That part of water withdrawn that is evaporated, transpired, incorporated into products or crops, consumed by humans or livestock, or otherwise removed from the immediate water environment. Also referred to as water consumed and water depletion.

CONVEYANCE LOSS. Water that is lost in transit from a pipe, canal, conduit, or ditch by leakage or evaporation. Generally, the water is not available for further use; however, leakage from an irrigation ditch, for example, may percolate to a ground-water source and be available for further use.

DOMESTIC WATER USE. Water for household purposes, such as drinking, preparing food, bathing, washing clothes and dishes, flushing toilets, and watering lawns and gardens. Also called residential water use. The water may be obtained from a public supply or be self-supplied.

GROUND WATER, CONFINED. Confined ground water is under pressure greater than atmospheric throughout the material in which the confined water occurs.

GROUND WATER, UNCONFINED. Unconfined ground water is water in an aquifer that has a water table.

HYDROELECTRIC POWER WATER USE. Water used in the generation of electricity at plants where the turbine generators are driven by falling water. Hydroelectric water use is classified as an instream use.

INDUSTRIAL WATER USE. Water used for industrial purposes such as fabrication, processing, washing, and cooling, and includes such industries as steel, chemical and allied products, paper and allied products, mining, and petroleum refining. The water may be obtained from a public supply or may be self-supplied.

INSTREAM WATER USE. Water that is used, but not withdrawn from a ground- or surface-water source for purposes such as hydroelectric power generation, navigation, water quality improvement, fish propagation, and recreation. Sometimes called nonwithdrawal use or in-channel use.

IRRIGATION WATER USE. Artificial application of water on land to assist in the growing of crops and pastures or to maintain vegetative growth in recreational lands, such as parks and golf courses.

LIVESTOCK WATER USE. Water for livestock watering, feed lots, dairy operations, fish farming, and other on-farm needs.

MAXIMUM CONTAMINANT LEVEL (MCL). Primary drinking water standard for public water supplies established by the U.S. Environmental Protection Agency (1996). MCLs are health related and legally enforceable.

MINING WATER USE. Water used for the extraction of minerals occurring naturally including solids, such as coal and ores; liquids, such as crude petroleum; and gases, such as natural gas. Also includes uses associated with quarrying, well operations (dewatering), milling (crushing, screening, washing, and floatation), and other preparations customarily done at the mine site or as part of a mining activity. 
OFFSTREAM USE. Water withdrawn or diverted from a ground- or surface-water source for public-water supply, industry, irrigation, livestock, thermoelectric power generation, and other uses. Sometimes called off-channel use or withdrawal use.

pH. A measure of the acidity or alkalinity of water. It is defined as the negative logarithm of the hydrogen-ion concentration. This parameter is dimensionless and generally has a range from 0.0 to 14.0 , with a pH of 7.0 representing neutral water. A pH of greater than 7.0 indicates the water is alkaline, whereas a pH of less than 7.0 indicates an acidic water.

PUBLIC SUPPLY. Water withdrawn by public and private water suppliers and delivered to groups of users. Public suppliers provide water for a variety of purposes, such as domestic, commercial, thermoelectric power, industrial, and public water use.

RAIN SHADOW. A dry region on the lee side of a mountain or mountain range. A rain shadow occurs because much of the moisture in an air mass is removed in the form of precipitation on the windward side of the mountain, as the air mass moves up and over the mountain. Because the air is then drier, precipitation on the lee side is noticeably less.

REPORTING LIMIT. Minimum concentration of an analyte that can be reliably measured and reported by the laboratory using a given analytical method.

SECONDARY MAXIMUM CONTAMINANT LEVEL (SMCL). Secondary drinking water standard for public water supplies established by the U.S. Environmental Protection Agency (1991). SMCLs primarily address aesthetic qualities of drinking water, and are not legally enforceable.

SELF-SUPPLIED DOMESTIC WATER USE. Water withdrawn from a water source by a user rather than a public supplier.

SODIUM-ADSORPTION RATIO (SAR). A measure of irrigation-water sodium hazard. It is the ratio of sodium to calcium plus magnesium adjusted for valence. The SAR value of water is considered along with specific conductance in determining suitability for irrigation.

SPECIFIC CAPACITY. The rate of discharge of water from the well divided by the drawdown of the water level within the well.

SPECIFIC CONDUCTANCE. A measure of water's ability to conduct an electrical current. Specific conductance is expressed in microsiemens per centimeter $(\mu \mathrm{S} / \mathrm{cm})$ at 25 degrees Celsius $\left(25^{\circ} \mathrm{C}\right)$. For water containing between 100 and $5,000 \mathrm{mg} / \mathrm{L}$ of dissolved solids, specific conductance in $\mu \mathrm{S} / \mathrm{cm}\left(\right.$ at $25^{\circ} \mathrm{C}$ ) multiplied by a factor between 0.55 and 0.71 will approximate the dissolved-solids concentration in $\mathrm{mg} / \mathrm{L}$. For most water, reasonable estimates can be obtained by multiplying by 0.64 .

THERMOELECTRIC POWER WATER USE. Water used in the process of the generation of thermoelectric power. The water may be obtained from a public supply or may be self supplied.

UNCONFINED AQUIFER. An aquifer that has a water table; an aquifer containing unconfined ground water.

WATER TABLE. The water table is that surface in an unconfined water body at which the pressure is atmospheric. It is defined by the levels at which water stands in wells that penetrate the water body just far enough to hold standing water. In wells penetrating to greater depths, the water level will stand above or below the water table if an upward or downward component of ground-water flow exists. 


\section{SUPPLEMENTAL DATA}





\section{Table 11. Records of selected wells and springs in Lincoln County, Wyoming}

[Local number: See text describing well-numbering system in the section titled Ground-Water Data. For a detailed description of the geologic units, see table 12. Primary use of water: B, bottling; C, commercial; H, domestic; I, irrigation; N, industrial; P, public supply; S, livestock; U, unused; Altitude of land surface, in feet above sea level. Water level: E, estimated; F, flowing; G, nearby flowing; $P$, pumping; $R$, recently pumped; $R p$, reported; $Z$, other; ft, feet. Discharge: gal/min, gallons per minute; E, estimated; Rp, reported by landowner or driller; Z, other; --, no data; NA, not applicable; NE, not established]

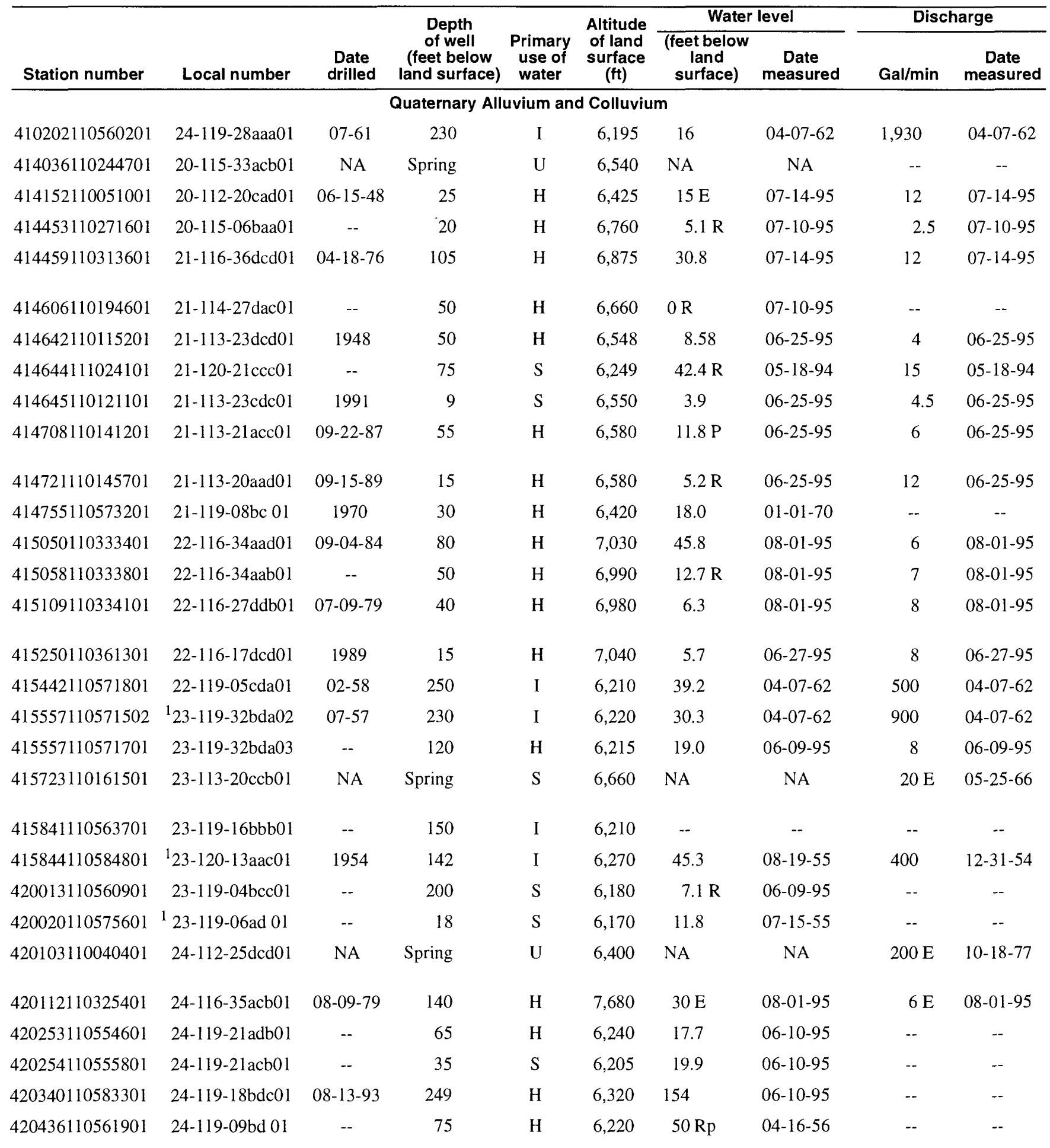


Table 11. Records of selected wells and springs in Lincoln County--Continued

\begin{tabular}{|c|c|c|c|c|c|c|c|c|c|}
\hline \multirow[b]{2}{*}{ Station number } & \multirow[b]{2}{*}{ Local number } & \multirow[b]{2}{*}{$\begin{array}{l}\text { Date } \\
\text { drilled }\end{array}$} & \multirow{2}{*}{$\begin{array}{c}\text { Depth } \\
\text { of well } \\
\text { (feet below } \\
\text { land surface) }\end{array}$} & \multirow[b]{2}{*}{$\begin{array}{l}\text { Primary } \\
\text { use of } \\
\text { water }\end{array}$} & \multirow{2}{*}{$\begin{array}{l}\text { Altitude } \\
\text { of land } \\
\text { surface } \\
\text { (ft) }\end{array}$} & \multicolumn{2}{|c|}{ Water level } & \multicolumn{2}{|c|}{ Discharge } \\
\hline & & & & & & $\begin{array}{c}\text { (feet below } \\
\text { land } \\
\text { surface) }\end{array}$ & $\begin{array}{c}\text { Date } \\
\text { measured }\end{array}$ & Gal/min & $\begin{array}{c}\text { Date } \\
\text { measured }\end{array}$ \\
\hline \multicolumn{10}{|c|}{ Quaternary Alluvium and Colluvium--Continued } \\
\hline 420525110401401 & 24-117-03dad01 & 1920 & 20 & $\mathrm{H}$ & 7,430 & 5.6 & $06-27-95$ & 11 & $06-27-95$ \\
\hline 420552110223301 & 24-114-06abb01 & 1920 & -- & $\mathrm{H}$ & 6,880 & $21.8 \mathrm{R}$ & $07-28-95$ & 12 & $07-28-95$ \\
\hline 420558110133001 & $25-113-35$ ddd 01 & $04-01-81$ & 75 & $\mathrm{H}$ & 6,595 & $22.3 \mathrm{R}$ & $07-28-95$ & 8 & $07-28-95$ \\
\hline 420905110111401 & $25-112-17 \mathrm{bcb} 01$ & -- & 60 & $\mathrm{H}$ & 6,510 & $20 \mathrm{R}, \mathrm{E}$ & $07-29-95$ & $7 \mathrm{E}$ & 07-29-95 \\
\hline 421115111012701 & $25-119-06 \mathrm{bca} 01$ & -- & 60 & $\mathrm{H}$ & 6,130 & 37.9 & $06-10-95$ & -. & -. \\
\hline 421154110095801 & $26-112-33 \mathrm{bba} 01$ & 1961 & 10 & $\mathrm{H}$ & 6,540 & $8 \mathrm{P}, \mathrm{Rp}$ & 1961 & 2 & $08-20-76$ \\
\hline 421155110100301 & $26-112-33 \mathrm{bba} 02$ & 1958 & 1 & $\mathrm{H}$ & 6,540 & $\mathrm{~F}, \mathrm{Rp}$ & $08-20-76$ & $5 \mathrm{E}$ & $08-20-76$ \\
\hline 421245110113001 & $26-112-30 \mathrm{abc01}$ & 1991 & 75 & $\mathrm{H}$ & 6,650 & 38.9 & $07-27-95$ & 8 & $07-27-95$ \\
\hline 421247111024601 & $26-120-25 \mathrm{cba} 01$ & -- & 210 & $\mathrm{H}$ & 6,070 & $\mathrm{~F}$ & 06-09-95 & -- & -- \\
\hline 421252110113601 & $26-112-19 \mathrm{dcd} 01$ & -- & 100 & $\mathrm{H}$ & 6,640 & $44.8 \mathrm{R}$ & $07-27-95$ & 4 & $07-27-95$ \\
\hline 421259110102901 & $26-112-20 \mathrm{ddb} 01$ & $11-30-73$ & 75 & $\mathrm{H}$ & 6,570 & $6 \mathrm{Z}$ & $08-20-76$ & 5 & $08-12-89$ \\
\hline 421301111023201 & $26-120-25 \mathrm{bda} 01$ & -- & 90 & $\mathrm{H}$ & 6,100 & $31.5 \mathrm{R}$ & 06-09-95 & -- & -- \\
\hline 421433110193801 & 26-114-13ad 01 & NA & Spring & $S$ & 7,040 & NA & NA & - & - \\
\hline 421500110122001 & $23-113-0201$ & $\mathrm{NA}$ & Spring & & 6,620 & $\mathrm{NA}$ & $\mathrm{NA}$ & $75 \mathrm{E}$ & $05-27-58$ \\
\hline 421630111015501 & $26-120-01 \mathrm{bb} 01$ & 1948 & 185 & $\mathrm{H}$ & 6,280 & $70.0 \mathrm{Rp}$ & $09-21-71$ & -- & -- \\
\hline 423238110533201 & $30-118-33 \mathrm{bcb} 01$ & $06-17-83$ & 85 & $\mathrm{H}$ & 6,945 & $25.5 \mathrm{R}$ & $10-07-93$ & 8 & $10-07-93$ \\
\hline 423610110544601 & $30-118-08 \mathrm{bbc} 01$ & -- & 130 & $\mathrm{H}$ & 6,620 & $11.6 \mathrm{R}$ & $07-29-92$ & -- & - \\
\hline 423620110554000 & $30-119-12 \mathrm{ac} 00$ & 1970 & 140 & $\mathrm{H}$ & 6,820 & $40 \mathrm{Rp}$ & $09-21-71$ & -- & -- \\
\hline 423710110544601 & 30-118-05bbb01 & $04-15-89$ & 98 & $\mathrm{H}$ & 6,620 & $52.4 \mathrm{R}$ & $07-28-92$ & -- & -- \\
\hline 423714110544401 & $31-118-32 \operatorname{ccc} 01$ & $10-18-85$ & 88 & $\mathrm{H}$ & 6,600 & $35.2 \mathrm{R}$ & 08-03-94 & 15 & 08-03-94 \\
\hline 423714110545001 & 31-118-31ddd01 & $11-18-86$ & 98 & $\mathrm{H}$ & 6,620 & $57.2 \mathrm{R}$ & $07-28-92$ & -- & -- \\
\hline 423748110551500 & $31-118-31$ ac 01 & 1953 & 45 & $\mathrm{H}$ & 6,540 & $10 \mathrm{Rp}$ & $08-61$ & -- & -- \\
\hline 423756110571201 & 31-119-35aad01 & -- & -- & $\mathrm{H}$ & 6,570 & $39.6 \mathrm{P}$ & $07-29-92$ & -- & -- \\
\hline 423838110551401 & $31-118-30 \mathrm{acc} 01$ & $05-28-82$ & 262 & $\mathrm{H}$ & 6,460 & $221 \mathrm{R}$ & 08-04-94 & 9 & 08-04-94 \\
\hline 423949110552501 & 31-118-19baa01 & -- & -- & $\mathrm{H}$ & 6,340 & 136 & $07-28-92$ & -- & -- \\
\hline 424006110591601 & $31-119-15 \mathrm{cbd} 01$ & $09-30-80$ & 65 & $\mathrm{H}$ & 6,320 & $32.0 \mathrm{R}$ & $07-29-92$ & -- & -- \\
\hline 424043110580001 & $31-119-11 \mathrm{cdc} 01$ & $04-10-87$ & 148 & $\mathrm{H}$ & 6,250 & $57.8 \mathrm{R}$ & $07-28-92$ & -- & -- \\
\hline 424128110585301 & $31-119-10 \mathrm{abc} 01$ & -- & 120 & 1 & 6,196 & $50 \mathrm{R}, \mathrm{Rp}$ & 08-23-89 & -- & -- \\
\hline 424132110575501 & 31-119-11bab01 & $04-24-79$ & 112 & $\mathrm{H}$ & 6,205 & $44.1 \mathrm{R}$ & $07-28-92$ & -- & --- \\
\hline 424133110574301 & 31-119-11abb01 & $06-20-83$ & 107 & $\mathrm{H}$ & 6,200 & $70.9 \mathrm{R}$ & 08-03-94 & 9 & 08-03-94 \\
\hline 424139110585601 & $31-119-03$ cdd 01 & $08-29-78$ & 70 & $\mathrm{H}$ & 6,193 & $20.8 \mathrm{P}$ & $07-27-92$ & 252 & 1978 \\
\hline 424215110585201 & $31-119-03 a b c 01$ & $10-02-84$ & 60 & $\mathrm{H}$ & 6,180 & $19.6 \mathrm{R}$ & $07-27-92$ & $10 \mathrm{Z}$ & 1984 \\
\hline 424216110585501 & 31-119-03bad01 & -- & 70 & $\mathrm{H}$ & 6,160 & $17.0 \mathrm{R}$ & $10-06-93$ & 6 & $10-06-93$ \\
\hline 424423110570901 & 32-119-23dad01 & -- & 75 & $\mathrm{H}$ & 6,140 & $25.5 \mathrm{R}$ & $10-08-93$ & 8 & $10-08-93$ \\
\hline 424520111014000 & 32-119-05bb 01 & $05-70$ & 35 & $\mathrm{H}$ & 6,110 & 13.7 & $09-10-71$ & $30 \mathrm{E}$ & 09-10-71 \\
\hline
\end{tabular}


Table 11. Records of selected wells and springs in Lincoln County--Continued

\begin{tabular}{|c|c|c|c|c|c|c|c|c|c|}
\hline \multirow[b]{2}{*}{ Station number } & \multirow[b]{2}{*}{ Local number } & \multirow[b]{2}{*}{$\begin{array}{l}\text { Date } \\
\text { drilled }\end{array}$} & \multirow{2}{*}{$\begin{array}{c}\text { Depth } \\
\text { of well } \\
\text { (feet below } \\
\text { land surface) }\end{array}$} & \multirow[b]{2}{*}{$\begin{array}{c}\text { Primary } \\
\text { use of } \\
\text { water }\end{array}$} & \multirow{2}{*}{$\begin{array}{l}\text { Altitude } \\
\text { of land } \\
\text { surface } \\
\text { (ft) }\end{array}$} & \multicolumn{2}{|c|}{ Water level } & \multicolumn{2}{|c|}{ Discharge } \\
\hline & & & & & & $\begin{array}{c}\text { (feet below } \\
\text { land } \\
\text { surface) }\end{array}$ & $\begin{array}{l}\text { Date } \\
\text { measured }\end{array}$ & $\mathrm{Gal} / \mathrm{min}$ & $\begin{array}{c}\text { Date } \\
\text { measured }\end{array}$ \\
\hline \multicolumn{10}{|c|}{ Quaternary Alluvium and Colluvium--Continued } \\
\hline 424521110594701 & $32-119-16 \mathrm{dac} 01$ & $09-30-80$ & 70 & $\mathrm{H}$ & 6,080 & $16.6 \mathrm{R}$ & 08-04-94 & 9 & 08-04-94 \\
\hline 424542110555801 & 32-119-13ada01 & $08-21-81$ & 73 & $\mathrm{H}$ & 6,120 & $22.5 \mathrm{R}$ & $07-27-92$ & -- & -- \\
\hline 424613110201401 & 21-114-27caa01 & $06-14-58$ & 45 & $\mathrm{~N}$ & 6,683 & $11 \mathrm{Rp}$ & $06-14-58$ & $85 \mathrm{Rp}$ & $06-14-58$ \\
\hline 424640110555000 & $33-118-32$ da 00 & $11-07-69$ & 146 & $\mathrm{H}$ & 6,180 & $116 \mathrm{Rp}$ & $11-07-69$ & -- & -- \\
\hline 424740110572601 & $33-118-31 \mathrm{ddc} 01$ & -- & 50 & $\mathrm{H}$ & 6,040 & $15.3 \mathrm{R}$ & $10-06-93$ & 9 & $10-06-93$ \\
\hline 424756110594801 & 33-119-35dac01 & $12-13-72$ & 65 & $\mathrm{H}$ & 6,035 & $13.0 \mathrm{R}$ & $08-04-94$ & $9 \mathrm{E}$ & 08-04-94 \\
\hline 424806110594701 & 33-119-35adc01 & 1948 & 28 & $\mathrm{H}$ & 6,035 & $10 \mathrm{R}, \mathrm{E}$ & 08-04-94 & 4 & 08-04-94 \\
\hline 424851110572801 & $33-118-30 \mathrm{dba} 01$ & $07-78$ & 80 & $\mathrm{H}$ & 6,070 & $21.2 \mathrm{R}$ & $07-25-92$ & -- & -- \\
\hline 424910110574401 & $33-118-30 a b c 01$ & 1946 & 70 & $\mathrm{H}$ & 6,030 & $22.1 \mathrm{R}$ & $07-25-92$ & - & -- \\
\hline 424926110595001 & $33-119-23 \mathrm{dcd} 01$ & -- & 40 & $\mathrm{H}$ & 6,010 & $7.7 \mathrm{R}$ & $07-29-92$ & -- & -- \\
\hline 425053110563201 & $33-118-17$ acb01 & -- & -- & $\mathrm{H}$ & 6,215 & $11.5 \mathrm{R}$ & $07-27-92$ & -- & -- \\
\hline 425107110533501 & $33-118-11 \mathrm{ccc} 01$ & $10-01-83$ & 105 & $\mathrm{H}$ & 6,430 & $58.1 \mathrm{P}$ & $07-27-92$ & -- & -- \\
\hline 425110110590000 & $33-119-12 \mathrm{~cd} 01$ & 1965 & 30 & $\mathrm{H}$ & 6,020 & -- & -- & -- & -- \\
\hline 425127110592701 & $33-119-12 \mathrm{cba} 02$ & 1947 & 33 & $\mathrm{C}$ & 6,000 & $3.9 \mathrm{R}$ & 08-06-94 & 50 & 08-06-94 \\
\hline 425135110592201 & $33-119-12 \mathrm{cba0} 1$ & -- & 25 & $\mathrm{H}$ & 6,000 & $5.1 \mathrm{R}$ & $10-06-93$ & 6 & $10-06-93$ \\
\hline 425200110591000 & $33-119-12 b a b 01$ & $09-67$ & 32 & $S$ & 5,960 & $20 \mathrm{Rp}$ & $09-67$ & -- & -- \\
\hline 425228110585301 & $33-119-01 \mathrm{acc} 01$ & $05-26-89$ & 160 & $\mathrm{H}$ & 5,985 & $39.4 \mathrm{P}$ & $07-26-92$ & -- & -- \\
\hline 425324110575201 & 34-118-31bdd01 & -- & -- & $\mathrm{H}$ & 6,110 & $43.9 \mathrm{R}$ & $07-28-92$ & -- & -- \\
\hline 425327110580701 & $34-118-31$ bca01 & -- & -- & $\mathrm{H}$ & 6,100 & -- & -- & -- & -- \\
\hline 425438110555701 & $34-118-21 \mathrm{ccc} 01$ & -- & -- & $\mathrm{H}$ & 6,220 & $172 \mathrm{P}$ & $07-27-92$ & -- & -- \\
\hline 425527111010401 & 34-119-22aba01 & -- & -- & $\mathrm{H}$ & 5,965 & $11.9 \mathrm{P}$ & $07-27-92$ & -- & -- \\
\hline 425540110581801 & $34-118-18 \mathrm{ccb} 01$ & -- & 70 & $\mathrm{H}$ & 6,040 & $19.2 \mathrm{R}$ & $07-27-92$ & 6 & $10-05-93$ \\
\hline 425555111013301 & $34-119-15 \mathrm{cab} 01$ & $12-83$ & 56 & $\mathrm{H}$ & 5,855 & $17.6 \mathrm{R}$ & $08-05-94$ & 7 & $08-05-94$ \\
\hline 425617110582001 & 34-119-13аaа01 & -- & -- & $\mathrm{H}$ & 6,050 & $27.4 \mathrm{R}$ & $07-28-92$ & -- & -- \\
\hline 425622110570901 & $34-118-07 \mathrm{ddd} 01$ & $02-22-83$ & -- & $\mathrm{U}$ & 6,160 & 120 & $08-05-94$ & -- & -- \\
\hline 425638111002201 & $34-119-11 \mathrm{cac} 01$ & -- & 60 & $\mathrm{H}$ & 5,880 & $8.6 \mathrm{R}$ & $10-07-93$ & 12 & $10-07-93$ \\
\hline 425650110584000 & $34-119-12 \mathrm{ac} 01$ & $05-28-67$ & 169 & I & 6,010 & -- & -- & $1,200 \mathrm{E}$ & $09-10-71$ \\
\hline 425759111003901 & 34-119-02bbb0l & -- & 130 & $\mathrm{~S}$ & 5,880 & -- & -- & -- & -- \\
\hline 425843111023501 & 35-119-33bda01 & 1989 & 50 & $\mathrm{H}$ & 5,785 & $17.9 \mathrm{P}$ & $08-06-94$ & 8 & 08-06-94 \\
\hline 425855111020601 & $35-119-33 \mathrm{abb} 01$ & -- & 50 & $\mathrm{H}$ & 5,775 & $12.0 \mathrm{R}$ & $10-08-93$ & 12 & $10-08-93$ \\
\hline 425857110591901 & $35-119-25 \mathrm{ccd} 01$ & -- & 119 & $\mathrm{H}$ & 5,960 & $95.3 \mathrm{R}$ & $07-25-92$ & 10 & $10-07-93$ \\
\hline 425857111021801 & 35-119-33aba01 & $11-28-83$ & 60 & $\mathrm{H}$ & 5,775 & $14.4 \mathrm{R}$ & 08-05-94 & 11 & $08-05-94$ \\
\hline 425903111022400 & $35-119-28 \mathrm{dcc} 00$ & -- & 31 & S & 5,775 & $17 \mathrm{Rp}$ & $11-22-54$ & -- & -- \\
\hline 430046111004301 & $35-119-15 \mathrm{ddd} 01$ & -. & 30 & $\mathrm{H}$ & 5,760 & $25.8 \mathrm{P}$ & $07-27-92$ & 6 & $10-05-93$ \\
\hline 430057111003801 & $35-119-14 \mathrm{cbc} 01$ & -. & 75 & $\mathrm{H}$ & 5,765 & $31.8 \mathrm{R}$ & $11-20-93$ & 10 & $11-20-93$ \\
\hline
\end{tabular}


Table 11. Records of selected wells and springs in Lincoln County--Continued

\begin{tabular}{|c|c|c|c|c|c|c|c|c|c|}
\hline \multirow[b]{2}{*}{ Station number } & \multirow[b]{2}{*}{ Local number } & \multirow[b]{2}{*}{$\begin{array}{c}\text { Date } \\
\text { drilled }\end{array}$} & \multirow{2}{*}{$\begin{array}{c}\text { Depth } \\
\text { of well } \\
\text { (feet below } \\
\text { land surface) }\end{array}$} & \multirow[b]{2}{*}{$\begin{array}{l}\text { Primary } \\
\text { use of } \\
\text { water }\end{array}$} & \multirow{2}{*}{$\begin{array}{c}\text { Altitude } \\
\text { of land } \\
\text { surface } \\
\text { (ft) }\end{array}$} & \multicolumn{2}{|c|}{ Water level } & \multicolumn{2}{|c|}{ Discharge } \\
\hline & & & & & & $\begin{array}{l}\text { (feet below } \\
\text { land } \\
\text { surface) }\end{array}$ & $\begin{array}{l}\text { Date } \\
\text { measured }\end{array}$ & $\mathrm{Gal} / \mathrm{min}$ & $\begin{array}{c}\text { Date } \\
\text { measured }\end{array}$ \\
\hline \multicolumn{10}{|c|}{ Quaternary Alluvium and Colluvium--Continued } \\
\hline 430331111013301 & $36-119-34 \mathrm{cbd} 01$ & -- & 85 & $\mathbf{H}$ & 5,715 & $20.8 \mathrm{R}$ & $10-07-93$ & 6 & $10-07-93$ \\
\hline 430356111013000 & $36-119-34 \mathrm{bac} 00$ & 1920 & 60 & $\mathrm{H}$ & 5,725 & 38 & 1965 & -- & -- \\
\hline 430441111003601 & $36-119-26 \mathrm{bcc} 01$ & $05-25-82$ & 140 & $\mathrm{H}$ & 5,860 & 102 & $10-16-94$ & $5 \mathrm{E}$ & $10-16-94$ \\
\hline 430444111003701 & $36-119-26 \mathrm{bcb} 01$ & 1978 & 110 & $\mathrm{H}$ & 5,860 & $98.2 \mathrm{R}$ & 08-05-94 & 6 & $08-05-94$ \\
\hline 430527111011601 & $36-119-22 \mathrm{caa} 01$ & $10-01-87$ & 110 & $\mathrm{H}$ & 5,762 & $27.7 \mathrm{R}$ & $07-26-92$ & -- & -- \\
\hline 430621111012100 & 36-119-15bdd00 & 1961 & 210 & $\mathrm{H}$ & 5,740 & $40 \mathrm{Rp}$ & $08-17-71$ & 12 & $08-17-71$ \\
\hline 430626111014501 & $36-119-15 b c c 01$ & 04-03-89 & 50 & $\mathrm{H}$ & 5,670 & $17.7 \mathrm{R}$ & $10-04-93$ & 12 & $10-04-93$ \\
\hline 430924111021001 & 37-118-31baa01 & $05-25-92$ & 160 & $\mathrm{H}$ & 5,645 & $44.3 \mathrm{R}$ & $09-12-93$ & 13 & $09-12-93$ \\
\hline 430951111010800 & $37-118-29 \mathrm{cab} 01$ & 1969 & 300 & $\mathrm{C}$ & 5,660 & $83 \mathrm{Rp}$ & 1969 & 30 & $08-13-71$ \\
\hline 431030111020300 & $37-118-19 \mathrm{dcb} 00$ & 1957 & 110 & $\mathrm{H}$ & 5,620 & -- & -- & -- & -- \\
\hline 431041111011801 & $37-118-20 \mathrm{cba} 01$ & $05-10-81$ & 100 & $\mathrm{C}$ & 5,655 & $43.7 \mathrm{R}$ & $09-12-93$ & -- & -- \\
\hline \multicolumn{10}{|c|}{ Quaternary Glacial Deposits } \\
\hline 424913110441901 & $33-116-30 \mathrm{bbb} 01$ & NA & Spring & $\mathrm{U}$ & 8,020 & NA & NA & $5 \mathrm{E}$ & $09-10-93$ \\
\hline 424919110444401 & NE & NA & Spring & $\mathrm{U}$ & 7,600 & NA & NA & 30 & $09-10-93$ \\
\hline \multicolumn{10}{|c|}{ Quaternary Landslide Deposits } \\
\hline 415620110462800 & $23-118-26 \mathrm{ddb} 01$ & NA & Spring & $S$ & 8,040 & NA & NA & 22 & $05-20-94$ \\
\hline 422402110462501 & $28-117-19 b c c 01$ & NA & Spring & $S$ & 7,440 & NA & NA & 2,000 & $09-13-94$ \\
\hline 423319110395201 & $\mathrm{NE}$ & NA & Spring & $\mathrm{U}$ & 8,660 & NA & NA & $25 \mathrm{E}$ & 08-02-94 \\
\hline 423330110395401 & $\mathrm{NE}$ & NA & Spring & & 8,550 & NA & NA & $5 \mathrm{E}$ & 08-02-94 \\
\hline \multicolumn{10}{|c|}{ Quaternary Terrace Deposits } \\
\hline 414749110410101 & $21-117-15 \mathrm{cad} 01$ & $07-29-82$ & 55 & $\mathrm{H}$ & 6,750 & $22.6 \mathrm{R}$ & $06-23-95$ & 14 & $06-23-95$ \\
\hline 414750110323001 & 21-116-14aaa01 & NA & Spring & & 6,900 & NA & NA & $7.5 \mathrm{E}$ & $05-26-58$ \\
\hline 414957110321501 & $21-116-01 b b 01$ & 1931 & 21 & $\mathrm{H}$ & 6,960 & 14.0 & $11-07-72$ & 270 & $11-07-72$ \\
\hline 415218110294501 & $22-115-20 \mathrm{cba} 01$ & NA & Spring & B & 7,160 & NA & NA & $3.5 \mathrm{E}$ & $06-15-94$ \\
\hline 415450110574501 & $22-119-05 \operatorname{ccc} 01$ & -- & 28 & H & 6,200 & 22.8 & $04-16-56$ & -- & -- \\
\hline 415555110572001 & 23-119-32bda01 & -- & 35 & $\mathrm{H}$ & 6,210 & 20.4 & $04-16-56$ & -- & -- \\
\hline 420106110555401 & 24-119-33ac 01 & -- & 22 & $\mathrm{H}$ & 6,200 & 8.3 & $08-22-55$ & -- & -- \\
\hline 420526110530801 & $\mathrm{NE}$ & NA & Spring & $\mathrm{S}$ & 6,390 & NA & $\mathrm{NA}$ & $20 \mathrm{E}$ & $06-11-95$ \\
\hline 420827110321301 & $25-115-20 \mathrm{bca} 01$ & $08-50$ & 5 & $\mathrm{H}$ & 7,400 & $\mathrm{~F}, \mathrm{Rp}$ & $08-50$ & $20 \mathrm{Rp}$ & $08-50$ \\
\hline 421145111014801 & 26-119-31cb 01 & 1947 & 59 & $\mathrm{H}$ & 6,080 & 16.7 & $08-31-47$ & -- & -- \\
\hline 423214110525101 & 30-118-33dbd01 & NA & Spring & $S$ & 7,080 & NA & $\mathrm{NA}$ & $5 \mathrm{E}$ & 08-03-94 \\
\hline \multicolumn{10}{|c|}{ Tertiary Rocks } \\
\hline 414007110172501 & $20-114-33 \mathrm{ddb} 01$ & $02-27-81$ & 881 & $\mathrm{~S}$ & 6,580 & $\mathrm{~F}$ & $07-31-95$ & 2 & $07-31-95$ \\
\hline 415210110303501 & $22-115-1901$ & NA & Spring & & 7,120 & NA & $\mathrm{NA}$ & -- & -- \\
\hline 415730110160301 & 23-113-20cbd01 & -- & 900 & H & 6,855 & $\mathrm{~F}$ & 06-13-94 & 15 & $06-13-94$ \\
\hline
\end{tabular}


Table 11. Records of selected wells and springs in Lincoln County--Continued

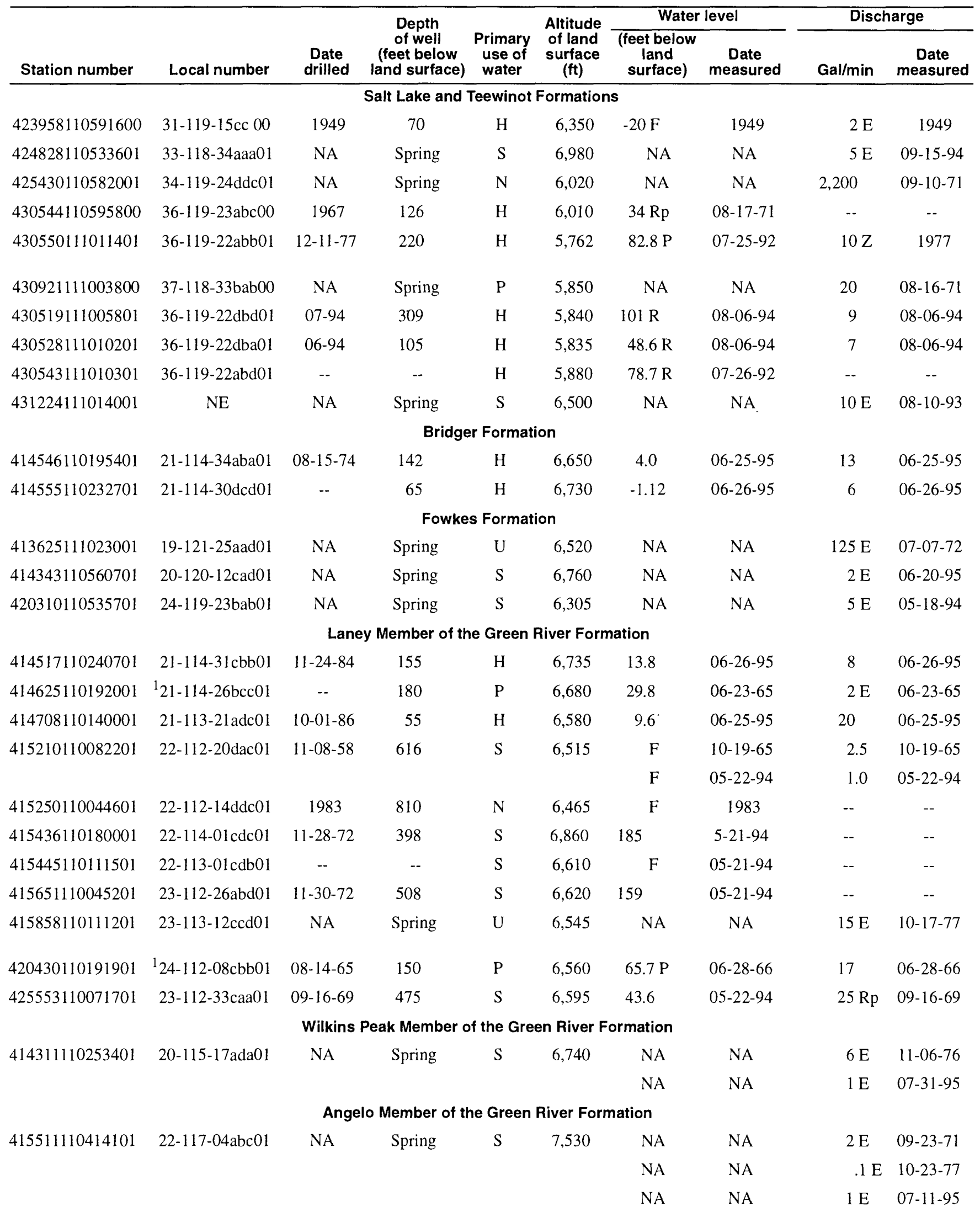


Table 11. Records of selected wells and springs in Lincoln County--Continued

\begin{tabular}{|c|c|c|c|c|c|c|c|c|c|}
\hline \multirow[b]{2}{*}{ Station number } & \multirow[b]{2}{*}{ Local number } & \multirow[b]{2}{*}{$\begin{array}{c}\text { Date } \\
\text { drilled }\end{array}$} & \multirow{2}{*}{$\begin{array}{c}\text { Depth } \\
\text { of well } \\
\text { (feet below } \\
\text { land surface) }\end{array}$} & \multirow[b]{2}{*}{$\begin{array}{l}\text { Primary } \\
\text { use of } \\
\text { water }\end{array}$} & \multirow{2}{*}{ 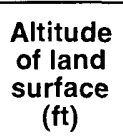 } & \multicolumn{2}{|c|}{ Water level } & \multicolumn{2}{|c|}{ Discharge } \\
\hline & & & & & & $\begin{array}{c}\text { (feet below } \\
\text { land } \\
\text { surface) }\end{array}$ & $\begin{array}{c}\text { Date } \\
\text { measured }\end{array}$ & $\mathrm{Gal} / \mathrm{min}$ & $\begin{array}{c}\text { Date } \\
\text { measured }\end{array}$ \\
\hline \multicolumn{10}{|c|}{ Fossil Butte Member of the Green River Formation } \\
\hline 413654110470701 & $19-118-20 \mathrm{cba} 01$ & NA & Spring & $\mathrm{H}$ & 7,075 & NA & NA & $1 \mathrm{E}$ & $06-23-95$ \\
\hline \multirow[t]{2}{*}{413715110470701} & 19-118-20bba01 & NA & Spring & $S$ & 6,960 & NA & NA & $80 \mathrm{E}$ & $11-06-76$ \\
\hline & & & & & & NA & NA & $25 \mathrm{E}$ & $06-23-95$ \\
\hline 413941110402201 & $19-117-05 \mathrm{bcb} 01$ & NA & Spring & $\mathrm{C}$ & 7,160 & NA & NA & $25 \mathrm{E}$ & $06-12-95$ \\
\hline 414254110505001 & 20-119-15dad01 & NA & Spring & $\mathrm{S}$ & 7,510 & F & $05-22-95$ & 20 & $05-22-95$ \\
\hline 414358110420501 & $20-118-12 \mathrm{acc0} 1$ & NA & Spring & $\mathrm{S}$ & 6,920 & NA & NA & $5 \mathrm{E}$ & $06-13-95$ \\
\hline 414458110495301 & $21-118-32 d d c 01$ & NA & Spring & $\mathrm{S}$ & 7,280 & NA & NA & $25 \mathrm{E}$ & $06-21-95$ \\
\hline 414539110415601 & 21-117-33abd01 & NA & Spring & $\mathrm{S}$ & 6,920 & NA & NA & $10 \mathrm{E}$ & 06-13-95 \\
\hline 414617110440901 & 21-117-30adc01 & NA & Spring & $S$ & 6,850 & NA & NA & $200 \mathrm{E}$ & 06-13-95 \\
\hline 414717110433001 & $21-117-20 \mathrm{bdb} 01$ & NA & Spring & $\mathrm{H}$ & 6,800 & NA & NA & $10 \mathrm{E}$ & 06-13-95 \\
\hline 415212110462201 & $22-118-23 \mathrm{dac} 01$ & NA & Spring & $P$ & 7,520 & NA & NA & 14 & $06-16-93$ \\
\hline 415757110433301 & 23-117-19aaa01 & NA & Spring & $S$ & 7,660 & NA & NA & $20 \mathrm{E}$ & 07-11-95 \\
\hline 415758110433301 & $23-117-17 \operatorname{ccc} 01$ & NA & Spring & $\mathrm{S}$ & 7,535 & NA & NA & $25 \mathrm{E}$ & 07-11-95 \\
\hline \multicolumn{10}{|c|}{ Wasatch Formation } \\
\hline \multirow[t]{2}{*}{413502110531101} & 19-119-32dad01 & NA & Spring & $\mathrm{S}$ & 7,740 & NA & NA & 80 & 06-09-72 \\
\hline & & & & & & NA & NA & $50 \mathrm{E}$ & $06-22-95$ \\
\hline 413658110421701 & 19-118-24caa01 & - & 200 & H & 6,795 & $110 \mathrm{Rp}$ & 11-06-76 & -- & -- \\
\hline \multirow[t]{3}{*}{413803110531701} & 19-119-17aac01 & NA & Spring & $S$ & 7,720 & NA & NA & $60 \mathrm{E}$ & $06-07-72$ \\
\hline & & & & & & NA & NA & $70 \mathrm{E}$ & 11-06-76 \\
\hline & & & & & & NA & NA & $25 \mathrm{E}$ & $06-22-95$ \\
\hline 413806110524601 & $19-119-16 \mathrm{bac} 01$ & NA & Spring & $S$ & 7,630 & NA & NA & $2 \mathrm{E}$ & $06-22-95$ \\
\hline 413825110513101 & $19-119-10 \mathrm{cda} 01$ & NA & Spring & $\mathrm{S}$ & 7,640 & NA & NA & $1 \mathrm{E}$ & $06-22-95$ \\
\hline \multirow[t]{2}{*}{414055110293601} & $20-116-26 \mathrm{cdd} 01$ & NA & Spring & $S$ & 6,820 & NA & NA & $.5 \mathrm{E}$ & 11-06-76 \\
\hline & & & & & & NA & NA & $.5 \mathrm{E}$ & 07-30-95 \\
\hline 414240110240501 & $20-115-15 \mathrm{ccd} 01$ & NA & Spring & $S$ & 6,610 & NA & NA & $1 \mathrm{E}$ & $07-31-95$ \\
\hline 414312110480501 & $20-118-18 \mathrm{bac} 01$ & NA & Spring & $\mathrm{S}$ & 7,760 & NA & NA & $5 \mathrm{E}$ & $06-12-95$ \\
\hline 414439110390501 & $20-117-04 \mathrm{bcd} 01$ & NA & Spring & $\mathrm{S}$ & 7,250 & NA & NA & $1 \mathrm{E}$ & 06-12-95 \\
\hline 414603110544701 & $21-119-27 \mathrm{dbc} 01$ & NA & Spring & $S$ & 6,780 & NA & NA & $.5 \mathrm{E}$ & 06-24-95 \\
\hline 414707110485901 & $21-118-21 \mathrm{acc} 01$ & NA & Spring & $S$ & 7,100 & NA & NA & 6 & 06-21-95 \\
\hline 414708110533901 & $21-119-23 \mathrm{acc} 01$ & NA & Spring & $\mathrm{S}$ & 6,590 & NA & NA & $5 \mathrm{E}$ & 06-24-95 \\
\hline 414800110442001 & $21-117-18 \mathrm{ac} 01$ & NA & Spring & $\mathrm{U}$ & 6,725 & NA & NA & 15 & $09-22-77$ \\
\hline 414925110473001 & $21-118-02 \mathrm{cc} 01$ & -- & 350 & $\mathrm{H}$ & 6,600 & -- & -- & -- & -- \\
\hline 414954110493701 & $21-118-04 b c b 01$ & NA & Spring & $\mathrm{H}$ & 6,570 & NA & NA & 9 & $06-16-93$ \\
\hline
\end{tabular}


Table 11. Records of selected wells and springs in Lincoln County--Continued

\begin{tabular}{|c|c|c|c|c|c|c|c|c|c|}
\hline \multirow[b]{2}{*}{ Station number } & \multirow[b]{2}{*}{ Local number } & \multirow[b]{2}{*}{$\begin{array}{l}\text { Date } \\
\text { drilled }\end{array}$} & \multirow{2}{*}{$\begin{array}{c}\text { Depth } \\
\text { of well } \\
\text { (feet below } \\
\text { land surface) }\end{array}$} & \multirow[b]{2}{*}{$\begin{array}{l}\text { Primary } \\
\text { use of } \\
\text { water }\end{array}$} & \multirow{2}{*}{$\begin{array}{l}\text { Altitude } \\
\text { of land } \\
\text { surface } \\
\text { (ft) }\end{array}$} & \multicolumn{2}{|c|}{ Water level } & \multicolumn{2}{|c|}{ Discharge } \\
\hline & & & & & & $\begin{array}{l}\text { (feet below } \\
\text { land } \\
\text { surface) }\end{array}$ & $\begin{array}{c}\text { Date } \\
\text { measured }\end{array}$ & Gal/min & $\begin{array}{c}\text { Date } \\
\text { measured }\end{array}$ \\
\hline \multicolumn{10}{|c|}{ Wasatch Formation--Continued } \\
\hline 415038110451001 & $22-118-25 \mathrm{dda} 01$ & $08-14-77$ & 465 & & 6,880 & $\mathrm{~F}$ & $10-20-77$ & $.1 \mathrm{E}$ & $10-20-77$ \\
\hline 415117110541301 & $22-119-26 \mathrm{cbc} 01$ & NA & Spring & $S$ & 6,650 & NA & NA & $1 \mathrm{E}$ & $06-21-95$ \\
\hline 415411110242301 & $22-115-12 \mathrm{adb} 01$ & NA & Spring & $S$ & 7,090 & NA & NA & $15 \mathrm{E}$ & $06-15-94$ \\
\hline \multirow[t]{2}{*}{415640110195001} & $23-114-27 \mathrm{cbc} 01$ & -- & -- & $\mathrm{S}$ & 6,765 & $\mathrm{~F}$ & $08-11-65$ & 8 & $08-11-65$ \\
\hline & & & & & & $\mathrm{F}$ & $06-13-94$ & 1 & $06-13-94$ \\
\hline 415839110241901 & $23-115-13 b b d 01$ & NA & Spring & $S$ & 7,080 & NA & NA & $1 E$ & $06-14-94$ \\
\hline 415839110261901 & 23-115-15bad01 & NA & Spring & $S$ & 7,280 & NA & NA & $5 \mathrm{E}$ & 06-14-94 \\
\hline 420611110392801 & $25-116-32 \mathrm{ccb} 01$ & NA & Spring & $S$ & 7,700 & NA & NA & $15 \mathrm{E}$ & 08-01-95 \\
\hline 420708110171101 & $25-113-29 \mathrm{dac} 01$ & $11-30-66$ & 120 & $S$ & 6,789 & 64.7 & $07-28-95$ & -- & -- \\
\hline 420754110423701 & $25-117-23 \mathrm{cdc} 01$ & NA & Spring & $S$ & 7,590 & NA & NA & $.1 \mathrm{E}$ & $08-01-95$ \\
\hline 420828110161501 & $25-113-21 \mathrm{aba} 01$ & $03-27-91$ & 180 & $S$ & 6,875 & 48.4 & $07-28-95$ & -- & -- \\
\hline 420958110192701 & $25-114-12$ daa01 & NA & Spring & $\mathrm{H}$ & 6,840 & NA & NA & $25 \mathrm{E}$ & $07-29-95$ \\
\hline 421027110253201 & $25-114-06 \mathrm{ddd} 01$ & NA & Spring & $S$ & 8,000 & NA & NA & $1 E$ & $07-29-95$ \\
\hline 421258110100401 & $26-112-21 \mathrm{lcb} 01$ & $05-50$ & 300 & $\mathrm{H}$ & 6,560 & $\mathrm{~F}$ & $08-20-76$ & -- & -- \\
\hline 421311110113601 & 26-112-19dab01 & $10-30-68$ & 122 & $\mathrm{H}$ & 6,617 & $18 \mathrm{Rp}$ & $10-30-68$ & $11 \mathrm{Rp}$ & $10-30-68$ \\
\hline 421344110145601 & 26-113-22aab01 & $11-01-76$ & 215 & $\mathrm{H}$ & 6,754 & $30 \mathrm{P}, \mathrm{Rp}$ & $11-01-76$ & $16 \mathrm{Rp}$ & $11-01-76$ \\
\hline 421446110435701 & 26-117-16bbd01 & NA & Spring & $S$ & 7,940 & NA & NA & $15 E$ & $07-11-95$ \\
\hline 421501110115001 & $26-112-07 \mathrm{bcd} 01$ & $06-27$ & 265 & $\mathrm{H}$ & 6,570 & $20.5 \mathrm{R}$ & $08-20-76$ & $25 \mathrm{Rp}$ & $08-20-76$ \\
\hline 421504110195501 & $26-114-12 \mathrm{db} 01$ & NA & Spring & $S$ & 7,180 & NA & NA & -- & -- \\
\hline 421512110132601 & $26-113-11 \mathrm{ac} 01$ & 1928 & 145 & $P$ & 6,700 & 21.0 & $06-16-66$ & $20 \mathrm{E}$ & $06-16-66$ \\
\hline 421540110114101 & 26-112-06acc01 & $04-18-62$ & 92 & $\mathrm{H}$ & 6,590 & $\mathrm{~F}, \mathrm{Rp}$ & $08-20-76$ & $10 \mathrm{Rp}$ & $08-20-76$ \\
\hline 421543110115601 & $26-112-06 \mathrm{ca} 01$ & $08-08-75$ & 123 & $\mathrm{H}$ & 6,600 & $9 \mathrm{P}, \mathrm{Rp}$ & $08-08-75$ & $10 \mathrm{Rp}$ & 08-08-75 \\
\hline 421545110452001 & $26-117-05 \mathrm{ccc} 01$ & NA & Spring & $S$ & 8,520 & NA & NA & 4 & $09-14-94$ \\
\hline 421551110120701 & $26-112-06 \mathrm{bcd} 01$ & $06-15-73$ & 55 & $\mathrm{H}$ & 6,615 & $17.0 \mathrm{R}$ & $08-20-76$ & $10 \mathrm{Rp}$ & $08-20-76$ \\
\hline 421554110112901 & 21-112-06acd01 & $08-01-66$ & 85 & $\mathrm{H}$ & 6,585 & F,Rp & $08-01-66$ & $30 \mathrm{Z}$ & 08-01-66 \\
\hline 425851110471201 & $23-118-11 \mathrm{ccd} 01$ & NA & Spring & $S$ & 7,980 & NA & NA & $40 \mathrm{E}$ & 05-20-94 \\
\hline & & & Evanstc & on Form & tion & & & & \\
\hline 414758110474701 & $21-118-15 \mathrm{dba} 01$ & NA & Spring & $S$ & 6,780 & NA & NA & $25 \mathrm{E}$ & $06-13-95$ \\
\hline 414811110405201 & 21-117-15acb01 & $07-31-85$ & 264 & $\mathrm{H}$ & 6,735 & 51.1 & $06-23-95$ & $.5 \mathrm{E}$ & 06-23-95 \\
\hline 415415110373001 & 22-116-07 01 & NA & Spring & & 7,140 & NA & NA & -- & -- \\
\hline 415515110373001 & 22-116-06ab 01 & NA & Spring & I & 7,250 & NA & NA & $1,000 \mathrm{E}$ & 09-30-71 \\
\hline
\end{tabular}


Table 11. Records of selected wells and springs in Lincoln County--Continued

\begin{tabular}{|c|c|c|c|c|c|c|c|c|c|}
\hline \multirow[b]{2}{*}{ Station number } & \multirow[b]{2}{*}{ Local number } & \multirow[b]{2}{*}{$\begin{array}{l}\text { Date } \\
\text { drilled }\end{array}$} & \multirow{2}{*}{$\begin{array}{c}\text { Depth } \\
\text { of well } \\
\text { (feet below } \\
\text { land surface) }\end{array}$} & \multirow[b]{2}{*}{$\begin{array}{c}\text { Primary } \\
\text { use of } \\
\text { water }\end{array}$} & \multirow{2}{*}{$\begin{array}{l}\text { Altitude } \\
\text { of land } \\
\text { surface } \\
\text { (ft) }\end{array}$} & \multicolumn{2}{|c|}{ Water level } & \multicolumn{2}{|c|}{ Discharge } \\
\hline & & & & & & $\begin{array}{c}\text { (feet below } \\
\text { land } \\
\text { surface) }\end{array}$ & $\begin{array}{c}\text { Date } \\
\text { measured }\end{array}$ & Gal/min & $\begin{array}{c}\text { Date } \\
\text { measured }\end{array}$ \\
\hline \multicolumn{10}{|c|}{ Adaville Formation } \\
\hline 414739110363001 & $21-116-17 \mathrm{~cd} 01$ & $06-19-75$ & 980 & $\mathrm{U}$ & 7,250 & $160 \mathrm{G}, \mathrm{Rp}$ & $06-19-75$ & -- & -- \\
\hline 414758110365001 & $21-116-17 \mathrm{cbb} 01$ & $04-29-76$ & 1,080 & $\mathrm{U}$ & 7,095 & $40 \mathrm{G}, \mathrm{Rp}$ & $04-29-76$ & -- & -- \\
\hline 414808110361401 & 21-116-17ac 01 & $05-05-76$ & 486 & $\mathrm{U}$ & 7,205 & 75 G.Rp & $05-05-76$ & -- & -- \\
\hline 414832110364801 & $21-116-08 \mathrm{cc} 01$ & $08-23-75$ & 1,200 & $\mathrm{U}$ & 6,985 & $\mathrm{~F}, \mathrm{Rp}$ & $08-23-75$ & $20 \mathrm{Rp}$ & $08-23-75$ \\
\hline 414832110372401 & $21-116-07 \mathrm{dc} 01$ & $08-23-75$ & 800 & $\mathrm{U}$ & 7,020 & $52 \mathrm{G}, \mathrm{Rp}$ & $08-23-75$ & -- & -- \\
\hline 414845110363201 & $21-116-08 \mathrm{ca} 01$ & $05-01-76$ & 320 & $\mathrm{U}$ & 7,120 & $12 \mathrm{G}, \mathrm{Rp}$ & $05-01-76$ & -- & -- \\
\hline \multicolumn{10}{|c|}{ Blind Bull Formation } \\
\hline 425840110383200 & $35-116-36 \mathrm{~b} 00$ & $\mathrm{NA}$ & Spring & $\mathrm{U}$ & 8,500 & NA & $\mathrm{NA}$ & $25 \mathrm{E}$ & $07-12-72$ \\
\hline \multicolumn{10}{|c|}{ Hilliard Shale } \\
\hline 413758110342000 & 19-116-18bd 01 & $11-65$ & 100 & $\mathrm{H}$ & 6,640 & 80 & $11-65$ & -- & -- \\
\hline 415315110333001 & 22-116-15add01 & NA & Spring & S & 7,130 & $\mathrm{NA}$ & $\mathrm{NA}$ & $5 \mathrm{E}$ & $06-16-94$ \\
\hline 415509110355501 & 22-116-05ada01 & $\mathrm{NA}$ & Spring & S & 7,400 & $\mathrm{NA}$ & $\mathrm{NA}$ & $4 \mathrm{E}$ & $10-20-77$ \\
\hline 415631110325701 & 23-116-26cad01 & NA & Spring & $S$ & 7,240 & NA & NA & 9 & $08-02-95$ \\
\hline \multicolumn{10}{|c|}{ Frontier Formation } \\
\hline 414053110314501 & $20-116-28 \mathrm{dcc} 01$ & NA & Spring & $\mathrm{U}$ & 7,040 & NA & NA & $.3 \mathrm{E}$ & $11-05-76$ \\
\hline 414440110030001 & $20-112-0301$ & NA & Spring & & 6,440 & NA & NA & -- & -- \\
\hline \multirow[t]{2}{*}{415541110363001} & 23-116-32cab01 & NA & Spring & $\mathrm{S}$ & 7,680 & NA & NA & $1.5 \mathrm{E}$ & $10-20-77$ \\
\hline & & & & & & NA & NA & $5 \mathrm{E}$ & 06-16-94 \\
\hline 415944110305301 & $23-115-06 \mathrm{ccd} 01$ & NA & Spring & $\mathrm{S}$ & 7,490 & NA & $\mathrm{NA}$ & $2 \mathrm{E}$ & $06-16-94$ \\
\hline \multicolumn{10}{|c|}{ Sage Junction Formation } \\
\hline 413819110565501 & $19-120-11 \mathrm{dcd} 01$ & NA & Spring & $S$ & 7,340 & NA & $\mathrm{NA}$ & $.2 \mathrm{E}$ & $05-20-95$ \\
\hline \multicolumn{10}{|c|}{ Aspen Shale } \\
\hline 413450110332201 & $19-116-32 \mathrm{ca} 01$ & -- & -- & $S$ & 6,560 & $\mathrm{~F}$ & -- & $1 \mathrm{E}$ & $09-11-64$ \\
\hline 414406110304801 & 20-116-10bda01 & $06-22-83$ & 100 & $\mathrm{H}$ & 6,960 & $60.0 \mathrm{P}$ & $06-26-95$ & 12 & $06-26-95$ \\
\hline \multirow[t]{2}{*}{415427110294701} & $22-115-08 \mathrm{bba} 01$ & -- & -- & S & 7,340 & $\mathrm{~F}$ & $10-05-72$ & 30 & $10-05-72$ \\
\hline & & & & & & $\mathrm{F}$ & 06-14-94 & 1 & 06-14-94 \\
\hline \multirow[t]{2}{*}{420023110285401} & $24-115-32 \mathrm{cbd} 01$ & $\mathrm{NA}$ & Spring & $\mathrm{S}$ & 7,520 & NA & $\mathrm{NA}$ & $1 \mathrm{E}$ & $10-20-77$ \\
\hline & & & & & & NA & NA & $2.5 \mathrm{E}$ & $06-16-94$ \\
\hline 421541110313801 & 26-115-07bba01 & $\mathrm{NA}$ & Spring & S & 8,260 & $\mathrm{NA}$ & $\mathrm{NA}$ & $3 \mathrm{E}$ & 07-13-95 \\
\hline 430635110503401 & $36-117-18 \mathrm{dc} 01$ & $\mathrm{NA}$ & Spring & $P$ & 6,300 & NA & NA & $20 \mathrm{E}$ & $09-14-71$ \\
\hline 430806110515401 & $\mathrm{NE}$ & $\mathrm{NA}$ & Spring & $\mathrm{U}$ & 6,240 & $\mathrm{NA}$ & $\mathrm{NA}$ & $5 \mathrm{E}$ & 09-19-93 \\
\hline 430816110520501 & NE & NA & Spring & $\mathrm{U}$ & 6,090 & NA & NA & $5 \mathrm{E}$ & 09-09-93 \\
\hline 430846110524200 & $\mathrm{NE}$ & NA & Spring & $\mathrm{C}$ & 5,980 & NA & $\mathrm{NA}$ & $15 \mathrm{E}$ & 09-08-71 \\
\hline 431158110520801 & $\mathrm{NE}$ & $\mathrm{NA}$ & Spring & $\mathrm{U}$ & 5,960 & NA & NA & $5 \mathrm{E}$ & 08-03-93 \\
\hline \multirow[t]{2}{*}{431252110500800} & $\mathrm{NE}$ & $\mathrm{NA}$ & Spring & $\mathrm{C}$ & 6,240 & NA & NA & $25 \mathrm{E}$ & $08-13-71$ \\
\hline & & & & & & $\mathrm{NA}$ & NA & 10 & 09-09-93 \\
\hline \multirow[t]{2}{*}{431300110483300} & $\mathrm{NE}$ & $\mathrm{NA}$ & Spring & $\mathrm{C}$ & 5,820 & NA & NA & 8 & $08-13-71$ \\
\hline & & & & & & NA & $\mathrm{NA}$ & 2 & $09-08-93$ \\
\hline
\end{tabular}


Table 11. Records of selected wells and springs in Lincoln County--Continued

\begin{tabular}{|c|c|c|c|c|c|c|c|c|c|}
\hline \multirow[b]{2}{*}{ Station number } & \multirow[b]{2}{*}{ Local number } & \multirow[b]{2}{*}{$\begin{array}{l}\text { Date } \\
\text { drilled }\end{array}$} & \multirow{2}{*}{$\begin{array}{c}\text { Depth } \\
\text { of well } \\
\text { (feet below } \\
\text { land surface) }\end{array}$} & \multirow[b]{2}{*}{$\begin{array}{l}\text { Primary } \\
\text { use of } \\
\text { water }\end{array}$} & \multirow{2}{*}{$\begin{array}{l}\text { Altitude } \\
\text { of land } \\
\text { surface } \\
\text { (ft) }\end{array}$} & \multicolumn{2}{|c|}{ Water level } & \multicolumn{2}{|c|}{ Discharge } \\
\hline & & & & & & $\begin{array}{l}\text { (feet below } \\
\text { land } \\
\text { surface) }\end{array}$ & $\begin{array}{c}\text { Date } \\
\text { measured }\end{array}$ & $\mathrm{Gal} / \mathrm{min}$ & $\begin{array}{c}\text { Date } \\
\text { measured }\end{array}$ \\
\hline \multicolumn{10}{|c|}{ Bear River Formation } \\
\hline 414712110275001 & 21-115-21 add01 & 1972 & -- & $S$ & 6,910 & $\mathrm{~F}$ & $06-17-94$ & $.2 \mathrm{E}$ & $06-17-94$ \\
\hline 415243110281701 & 22-115-21baa01 & NA & Spring & $\mathrm{S}$ & 7,340 & NA & NA & $1 \mathrm{E}$ & $06-15-94$ \\
\hline \multirow[t]{2}{*}{420928110283201} & 25-115-14bac01 & NA & Spring & $\mathrm{U}$ & 7,770 & NA & NA & $15 \mathrm{E}$ & $08-14-72$ \\
\hline & & & & & & NA & NA & $4 \mathrm{E}$ & $10-18-77$ \\
\hline 425435110433001 & $34-116-19 \mathrm{~d} 01$ & NA & Spring & $\mathrm{H}$ & 6,820 & NA & NA & $15 \mathrm{E}$ & $09-14-71$ \\
\hline 425830110460001 & $35-117-35 \mathrm{a} 01$ & NA & Spring & $P$ & 6,720 & NA & NA & $8 \mathrm{E}$ & $08-24-71$ \\
\hline \multirow[t]{2}{*}{430345110510601} & $36-117-31 \mathrm{bcd} 01$ & NA & Spring & $\mathrm{U}$ & 6,395 & NA & NA & $5 \mathrm{E}$ & $09-14-71$ \\
\hline & & & & & & NA & NA & 3 & $08-11-93$ \\
\hline 430430110503501 & 36-117-30dbb01 & NA & Spring & $P$ & 6,600 & NA & NA & $5 \mathrm{E}$ & $08-24-71$ \\
\hline \multicolumn{10}{|c|}{ Thomas Fork Formation } \\
\hline 413819110580101 & 19-120-10ddc01 & NA & Spring & $S$ & 7,260 & NA & NA & $.5 \mathrm{E}$ & $05-20-95$ \\
\hline 413902111001401 & 19-120-08aab01 & NA & Spring & $S$ & 6,830 & NA & NA & $.2 \mathrm{E}$ & $05-20-95$ \\
\hline \multicolumn{10}{|c|}{ Gannett Group } \\
\hline 413510111010401 & $19-120-32 \mathrm{cbb} 01$ & NA & Spring & $S$ & 6,760 & NA & NA & .25 & $05-21-95$ \\
\hline 413551110593201 & $19-120-28 \mathrm{cda} 01$ & NA & Spring & $S$ & 7,140 & NA & NA & $.25 \mathrm{E}$ & $05-21-95$ \\
\hline 414321110582801 & $20-120-15$ bad01 & NA & Spring & $S$ & 6,620 & NA & NA & $1 \mathrm{E}$ & $06-20-95$ \\
\hline 415230110270701 & $22-115-22 \mathrm{bda0} 1$ & NA & Spring & $S$ & 7,340 & NA & NA & 3 & $05-22-94$ \\
\hline 415635110282801 & $23-115-29 \mathrm{dbb} 01$ & NA & Spring & $S$ & 7,330 & NA & NA & $10 \mathrm{E}$ & 06-14-94 \\
\hline \multirow[t]{2}{*}{415645110281701} & $23-115-29$ acd01 & NA & Spring & $S$ & 7,170 & NA & $\mathrm{NA}$ & 121 & $10-17-77$ \\
\hline & & & & & & NA & NA & $30 \mathrm{E}$ & 06-14-94 \\
\hline 420533110533501 & 24-119-28bdb01 & NA & Spring & $P$ & 6,390 & NA & NA & $700 \mathrm{Rp}$ & $09-17-71$ \\
\hline 421558110571301 & $26-119-02 \mathrm{ccb} 01$ & NA & Spring & $S$ & 7,670 & NA & NA & $.5 \mathrm{E}$ & $07-24-94$ \\
\hline 421642110431901 & $27-117-34 \mathrm{cdc} 01$ & NA & Spring & $S$ & 8,820 & NA & NA & $10 \mathrm{E}$ & 07-11-95 \\
\hline 422036110572800 & 27-119-10dab00 & NA & Spring & $\mathrm{U}$ & 7,320 & NA & NA & $20 \mathrm{E}$ & $09-16-71$ \\
\hline 423340110544000 & $30-118-29 \mathrm{bb} 01$ & NA & Spring & I & 7,000 & NA & NA & $100 \mathrm{E}$ & $09-14-71$ \\
\hline 423348110523000 & $30-118-35 \mathrm{ac} 01$ & NA & Spring & U & 7,240 & NA & NA & $50 \mathrm{E}$ & $07-09-72$ \\
\hline \multirow[t]{2}{*}{431306110472400} & NE & NA & Spring & $\mathrm{C}$ & 6,060 & NA & NA & 10 & $08-13-71$ \\
\hline & & & & & & NA & NA & 1.5 & 09-09-93 \\
\hline \multicolumn{10}{|c|}{ Stump Formation } \\
\hline 425552110425801 & $34-116-17 b d b 01$ & NA & Spring & $\mathbf{P}$ & 6,600 & NA & NA & $10 \mathrm{E}$ & $09-09-93$ \\
\hline \multicolumn{10}{|c|}{ Preuss Sandstone or Preuss Redbeds } \\
\hline \multirow[t]{2}{*}{422333110575500} & $28-119-27 \mathrm{bad} 00$ & $\mathrm{NA}$ & Spring & $S$ & 6,470 & NA & NA & $20 \mathrm{E}$ & $09-15-71$ \\
\hline & & & & & & NA & NA & 1 & $09-17-94$ \\
\hline 422802110575901 & $29-119-26 \mathrm{cac} 01$ & NA & Spring & $S$ & 6,620 & NA & NA & $.1 \mathrm{E}$ & $07-24-94$ \\
\hline \multirow[t]{2}{*}{422828110581200} & $29-119-26 b b c 01$ & NA & Spring & $S$ & 6,760 & NA & NA & $50 \mathrm{E}$ & $09-15-71$ \\
\hline & & & & & & NA & NA & $2 \mathrm{E}$ & 09-15-94 \\
\hline
\end{tabular}


Table 11. Records of selected wells and springs in Lincoln County--Continued

\begin{tabular}{|c|c|c|c|c|c|c|c|c|c|}
\hline \multirow[b]{2}{*}{ Station number } & \multirow[b]{2}{*}{ Local number } & \multirow[b]{2}{*}{$\begin{array}{l}\text { Date } \\
\text { drilled }\end{array}$} & \multirow{2}{*}{$\begin{array}{c}\text { Depth } \\
\text { of well } \\
\text { (feet below } \\
\text { land surface) }\end{array}$} & \multirow[b]{2}{*}{$\begin{array}{l}\text { Primary } \\
\text { use of } \\
\text { water }\end{array}$} & \multirow{2}{*}{$\begin{array}{c}\text { Altitude } \\
\text { of land } \\
\text { surface } \\
\text { (ft) }\end{array}$} & \multicolumn{2}{|c|}{ Water level } & \multicolumn{2}{|c|}{ Discharge } \\
\hline & & & & & & $\begin{array}{l}\text { (feet below } \\
\text { land } \\
\text { surface) }\end{array}$ & $\begin{array}{c}\text { Date } \\
\text { measured }\end{array}$ & Gal/min & $\begin{array}{c}\text { Date } \\
\text { measured }\end{array}$ \\
\hline \multicolumn{10}{|c|}{ Twin Creek Limestone } \\
\hline 414708110533101 & $21-119-23$ acd01 & NA & Spring & $\mathrm{S}$ & 6,640 & NA & NA & $15 \mathrm{E}$ & $06-24-95$ \\
\hline 420906110582301 & $\mathrm{NE}$ & NA & Spring & $\mathrm{H}$ & 6,200 & NA & NA & $25 \mathrm{E}$ & $06-10-95$ \\
\hline 421557110263201 & $26-115-01 \mathrm{cbc} 01$ & NA & Spring & $S$ & 8,300 & NA & NA & $30 \mathrm{E}$ & $07-13-95$ \\
\hline 422409110323701 & 28-116-24ada01 & NA & Spring & $S$ & 8,020 & NA & NA & $2 \mathrm{E}$ & $08-07-94$ \\
\hline 424730110550000 & 32-118-06aa 01 & NA & Spring & $\mathrm{P}$ & 6,660 & NA & NA & $20 \mathrm{E}$ & $09-10-71$ \\
\hline \multicolumn{10}{|c|}{ Nugget Sandstone } \\
\hline 414721110503401 & 21-118-20bbd01 & NA & Spring & $S$ & 7,360 & NA & NA & $5 \mathrm{E}$ & $06-21-95$ \\
\hline 415540110511300 & 23-118-31dca00 & NA & Spring & $S$ & 7,450 & NA & NA & 5 & $06-17-93$ \\
\hline 415616110512001 & $23-118-30 \mathrm{dcc} 01$ & NA & Spring & $S$ & 7,380 & NA & NA & 42 & $06-17-93$ \\
\hline 415704111003701 & $23-120-26 a b 01$ & NA & Spring & $\mathrm{H}$ & 6,450 & NA & NA & -- & -- \\
\hline 420120110250301 & 24-115-35abc01 & NA & Spring & $S$ & 7,380 & NA & NA & $1 \mathrm{E}$ & $06-16-94$ \\
\hline 420429110504301 & $24-118-08 \mathrm{cba} 01$ & NA & Spring & $S$ & 6,800 & NA & NA & $2 \mathrm{E}$ & 06-11-95 \\
\hline 420430110505701 & 24-118-07daa01 & NA & Spring & $S$ & 6,770 & NA & NA & $5 \mathrm{E}$ & $06-11-95$ \\
\hline \multirow[t]{2}{*}{421211110261901} & 26-115-26adc01 & NA & Spring & $\mathrm{U}$ & 8,450 & NA & NA & $10 \mathrm{E}$ & $10-18-77$ \\
\hline & & & & & & NA & NA & $2 \mathrm{E}$ & $07-13-95$ \\
\hline 421313110255001 & $26-115-24 \mathrm{dcd} 01$ & NA & Spring & $S$ & 8,100 & NA & NA & $5 \mathrm{E}$ & $07-29-95$ \\
\hline \multirow[t]{2}{*}{421405110275601} & $26-115-15 \mathrm{cdb} 01$ & NA & Spring & $S$ & 8,060 & NA & NA & $5 \mathrm{E}$ & $10-18-77$ \\
\hline & & & & & & NA & NA & $20 \mathrm{E}$ & $07-13-95$ \\
\hline 421429110263501 & $26-115-13 b c c 01$ & NA & Spring & $S$ & 8,360 & NA & NA & $1 \mathrm{E}$ & $07-13-95$ \\
\hline \multirow[t]{2}{*}{422821110395800} & $29-116-28 b c b 00$ & NA & Spring & $\mathrm{U}$ & 8,900 & NA & NA & $75 \mathrm{E}$ & $10-15-71$ \\
\hline & & & & & & NA & NA & $10 \mathrm{E}$ & $08-07-94$ \\
\hline 423632110394401 & $\mathrm{NE}$ & NA & Spring & $\mathrm{U}$ & 8,000 & NA & NA & $1,400 \mathrm{E}$ & $07-07-72$ \\
\hline \multirow[t]{2}{*}{423645110395401} & $\mathrm{NE}$ & NA & Spring & $\mathrm{U}$ & 7,890 & NA & NA & $100 \mathrm{E}$ & $09-14-71$ \\
\hline & & & & & & NA & NA & $8 \mathrm{E}$ & $08-02-94$ \\
\hline 423654110393901 & $\mathrm{NE}$ & NA & Spring & $\mathrm{U}$ & 7,880 & NA & NA & $15 \mathrm{E}$ & $09-10-93$ \\
\hline 424356110394201 & $\mathrm{NE}$ & NA & Spring & $\mathrm{U}$ & 7,640 & NA & NA & $140 \mathrm{E}$ & $07-15-72$ \\
\hline 424647110550501 & $32-118-07 \mathrm{aba} 01$ & -- & 230 & $\mathrm{H}$ & 6,280 & $52.1 \mathrm{R}$ & 08-07-94 & 8 & 08-07-94 \\
\hline 430602110423501 & $\mathrm{NE}$ & NA & Spring & $S$ & 6,840 & NA & NA & 12 & $08-12-93$ \\
\hline \multirow[t]{2}{*}{430713110425401} & 'NE & NA & Spring & $S$ & 6,900 & NA & NA & $200 \mathrm{E}$ & $09-14-71$ \\
\hline & & & & & & NA & NA & $150 \mathrm{E}$ & $08-12-93$ \\
\hline \multicolumn{10}{|c|}{ Thaynes Limestone } \\
\hline \multirow[t]{2}{*}{415242110502001} & $22-118-17 \mathrm{dcc} 01$ & 1966 & 600 & $\mathrm{U}$ & 6,720 & $\mathrm{~F}$ & $09-22-71$ & 150 & $06-07-65$ \\
\hline & & & & & & $\mathrm{F}$ & $06-16-93$ & 12 & $06-16-93$ \\
\hline 415304110501601 & $22-118-17 \mathrm{dbb} 01$ & NA & Spring & $\mathrm{H}$ & 6,760 & NA & NA & 45 & $06-16-93$ \\
\hline 420837110490801 & 25-118-23aba01 & NA & Spring & $S$ & 7,710 & NA & NA & $20 \mathrm{E}$ & $06-24-95$ \\
\hline 420958110242401 & 25-114-08daa01 & NA & Spring & $S$ & 7,420 & NA & NA & $1 \mathrm{E}$ & $07-29-95$ \\
\hline 423116110420901 & 29-116-07bbb01 & NA & Spring & $\mathrm{H}$ & 8,605 & NA & NA & $10 \mathrm{E}$ & $08-04-93$ \\
\hline
\end{tabular}


Table 11. Records of selected wells and springs in Lincoln County--Continued

\begin{tabular}{|c|c|c|c|c|c|c|c|c|c|}
\hline \multirow[b]{2}{*}{ Station number } & \multirow[b]{2}{*}{ Local number } & \multirow[b]{2}{*}{$\begin{array}{l}\text { Date } \\
\text { drilled }\end{array}$} & \multirow{2}{*}{$\begin{array}{c}\text { Depth } \\
\text { of well } \\
\text { (feet below } \\
\text { land surface) }\end{array}$} & \multirow[b]{2}{*}{$\begin{array}{l}\text { Primary } \\
\text { use of } \\
\text { water }\end{array}$} & \multirow{2}{*}{$\begin{array}{c}\text { Altitude } \\
\text { of land } \\
\text { surface } \\
\text { (ft) }\end{array}$} & \multicolumn{2}{|c|}{ Water level } & \multicolumn{2}{|c|}{ Discharge } \\
\hline & & & & & & $\begin{array}{c}\text { (feet below } \\
\text { land } \\
\text { surface) }\end{array}$ & $\begin{array}{c}\text { Date } \\
\text { measured }\end{array}$ & Gal/min & $\begin{array}{c}\text { Date } \\
\text { measured }\end{array}$ \\
\hline \multicolumn{10}{|c|}{ Thaynes Limestone--Continued } \\
\hline 423435110440501 & NE & NA & Spring & $\mathrm{U}$ & 9,020 & NA & NA & $300 \mathrm{E}$ & $08-04-93$ \\
\hline 424955110595500 & $33-119-23$ ac 01 & NA & Spring & $\mathrm{R}$ & 6,080 & NA & NA & $38 \mathrm{E}$ & $08-20-71$ \\
\hline 425003110595001 & 33-119-23abd01 & $11-08-71$ & 195 & $\mathbf{H}$ & 6,140 & $86.7 \mathrm{R}$ & $07-26-92$ & -- & -- \\
\hline \multicolumn{10}{|c|}{ Woodside Shale } \\
\hline 420408110493601 & $24-118-09 \operatorname{ccc} 01$ & NA & Spring & $\mathrm{H}$ & 7,040 & NA & NA & $2 \mathrm{E}$ & $06-11-95$ \\
\hline 420415110494401 & 24-118-08dda01 & NA & Spring & $S$ & 7,000 & NA & NA & $10 \mathrm{E}$ & $06-11-95$ \\
\hline 424946110594001 & 33-119-23daa01 & $01-20-87$ & -- & $\mathrm{H}$ & 6,015 & $4.5 \mathrm{R}$ & $07-26-92$ & -- & -- \\
\hline \multicolumn{10}{|c|}{ Dinwoody Formation } \\
\hline 422327110361901 & 28-116-28aac01 & NA & Spring & $\mathrm{S}$ & 8,920 & NA & NA & $5 \mathrm{E}$ & $09-16-94$ \\
\hline 423126110420401 & $29-116-06 \mathrm{cca} 01$ & NA & Spring & $\mathrm{U}$ & 8,595 & NA & NA & $50 \mathrm{E}$ & 08-05-93 \\
\hline \multicolumn{10}{|c|}{ Phosphoria Formation and related rocks ${ }^{2}$} \\
\hline 415150110495501 & 22-118-29aab01 & -- & 530 & $\mathrm{U}$ & 6,660 & $\mathrm{~F}$ & $06-11-65$ & $200 \mathrm{E}$ & $06-11-65$ \\
\hline 415230110494801 & 22-118-20ad 01 & NA & Spring & I & 6,800 & NA & NA & 300 & $09-22-71$ \\
\hline \multicolumn{10}{|c|}{ Tensleep Sandstone } \\
\hline 430800110412700 & $\mathrm{NE}$ & NA & Spring & $\mathrm{U}$ & 8,600 & NA & NA & $175 \mathrm{E}$ & $07-10-72$ \\
\hline \multirow[t]{2}{*}{431158110562500} & $\mathrm{NE}$ & NA & Spring & $\mathrm{C}$ & 6,280 & NA & NA & $200 \mathrm{E}$ & $09-08-71$ \\
\hline & & & & & & NA & NA & 7 & 09-08-93 \\
\hline \multicolumn{10}{|c|}{ Wells Formation } \\
\hline 414950111013001 & $21-120-10 \mathrm{da} 01$ & 1971 & 191 & $\mathrm{~N}$ & 6,245 & $42.0 \mathrm{Rp}$ & $09-23-71$ & 300 & $09-23-71$ \\
\hline \multirow[t]{2}{*}{421443110470400} & 26-117.5-13bad00 & NA & Spring & $\mathrm{S}$ & 8,000 & NA & NA & $1,600 \mathrm{E}$ & $09-17-71$ \\
\hline & & & & $\mathrm{S}$ & & NA & NA & 1,100 & $09-13-94$ \\
\hline 423155110421501 & NE & NA & Spring & $\mathrm{U}$ & 9,000 & NA & NA & $200 \mathrm{E}$ & $08-25-71$ \\
\hline \multirow[t]{2}{*}{423230110421501} & $\mathrm{NE}$ & NA & Spring & $\mathrm{U}$ & 8,320 & NA & NA & 2,200 & $09-14-71$ \\
\hline & & & & & & NA & NA & $1,800 \mathrm{E}$ & 08-04-93 \\
\hline 425132110380301 & $33-116-12 b 01$ & NA & Spring & $\mathrm{U}$ & 7,600 & NA & NA & $1,500 \mathrm{E}$ & $07-13-72$ \\
\hline \multicolumn{10}{|c|}{ Madison Limestone } \\
\hline 421543110195501 & $26-114-01 \mathrm{dcc} 01$ & NA & Spring & $\mathrm{S}$ & 7,360 & NA & NA & $15 \mathrm{E}$ & $08-17-76$ \\
\hline \multirow[t]{2}{*}{421702110201501} & $26-114-01$ bac01 & NA & Spring & I & 7,420 & NA & NA & $4,000 \mathrm{E}$ & $09-65$ \\
\hline & & & & I & & NA & NA & 5,500 & 11-18-76 \\
\hline 423148110411601 & 29-116-06add01 & NA & Spring & $\mathrm{U}$ & 8,620 & NA & NA & $50 \mathrm{E}$ & 08-05-93 \\
\hline \multirow[t]{2}{*}{424440110505001} & NE & NA & Spring & $\mathrm{P}$ & 7,360 & NA & NA & ${ }^{3} 10 \mathrm{E}$ & $10-04-93$ \\
\hline & & & & & & NA & NA & ${ }^{3} 15,000 \mathrm{E}$ & $10-04-93$ \\
\hline 425040110513000 & 33-118-13acc01 & NA & Spring & $P$ & 6,880 & NA & NA & $150 \mathrm{E}$ & $09-10-71$ \\
\hline 430838110582200 & $37-118-34 \mathrm{ded} 00$ & NA & Spring & & 6,000 & NA & NA & 15 & $09-08-71$ \\
\hline \multicolumn{10}{|c|}{ Darby Formation } \\
\hline 425951110562201 & NE & NA & Spring & $\mathrm{U}$ & 7,360 & NA & NA & $15 \mathrm{E}$ & $09-15-94$ \\
\hline
\end{tabular}


Table 11. Records of selected wells and springs in Lincoln County--Continued

\begin{tabular}{|c|c|c|c|c|c|c|c|c|c|}
\hline \multirow[b]{2}{*}{ Station number } & \multirow[b]{2}{*}{ Local number } & \multirow[b]{2}{*}{$\begin{array}{c}\text { Date } \\
\text { drilled }\end{array}$} & \multirow{2}{*}{$\begin{array}{c}\text { Depth } \\
\text { of well } \\
\text { (feet below } \\
\text { land surface) }\end{array}$} & \multirow[b]{2}{*}{$\begin{array}{l}\text { Primary } \\
\text { use of } \\
\text { water }\end{array}$} & \multirow{2}{*}{$\begin{array}{c}\text { Altitude } \\
\text { of land } \\
\text { surface } \\
\text { (ft) }\end{array}$} & \multicolumn{2}{|c|}{ Water level } & \multicolumn{2}{|c|}{ Discharge } \\
\hline & & & & & & $\begin{array}{l}\text { (feet below } \\
\text { land } \\
\text { surface) }\end{array}$ & $\begin{array}{c}\text { Date } \\
\text { measured }\end{array}$ & Gal/min & $\begin{array}{c}\text { Date } \\
\text { measured }\end{array}$ \\
\hline \multicolumn{10}{|c|}{ Bighorn Dolomite } \\
\hline 421504110183101 & $26-113-07 \mathrm{c} 01$ & NA & Spring & $\mathrm{H}$ & 7,700 & NA & $\mathrm{NA}$ & $3 \mathrm{E}$ & $10-18-77$ \\
\hline \multirow[t]{2}{*}{421509110185301} & 26-113-07bda01 & NA & Spring & $S$ & 7,440 & NA & NA & $5 \mathrm{E}$ & $10-18-77$ \\
\hline & & & & & & NA & NA & $10 \mathrm{E}$ & $07-27-95$ \\
\hline 421612110182301 & 26-113-06ada01 & NA & Spring & $S$ & 7,620 & NA & NA & 2 & $07-12-95$ \\
\hline 425420110522001 & 34-118-26aad01 & NA & Spring & $P$ & 6,700 & NA & NA & $3,200 \mathrm{Rp}$ & $09-10-71$ \\
\hline 430157110580500 & $\mathrm{NE}$ & NA & Spring & I & 6,420 & NA & NA & $450 \mathrm{E}$ & $08-17-71$ \\
\hline \multirow[t]{2}{*}{431200111014500} & $37-118-18 a a b 00$ & NA & Spring & $\mathrm{C}$ & 5,940 & NA & NA & $250 \mathrm{E}$ & $08-13-71$ \\
\hline & & & & & & NA & NA & $200 \mathrm{Rp}$ & $08-12-93$ \\
\hline
\end{tabular}

${ }^{\mathrm{I}}$ Additional water-level data can be found in the USGS data base or published reports.

${ }^{2}$ In Wyoming, the Phosphoria Formation is synonymous with the Park City Formation (Lane, 1973, p. 4).

${ }^{3}$ Station 424440110505001 is the Periodic Spring. The flow fluctuated between the two discharges every 18 minutes during the visit. 


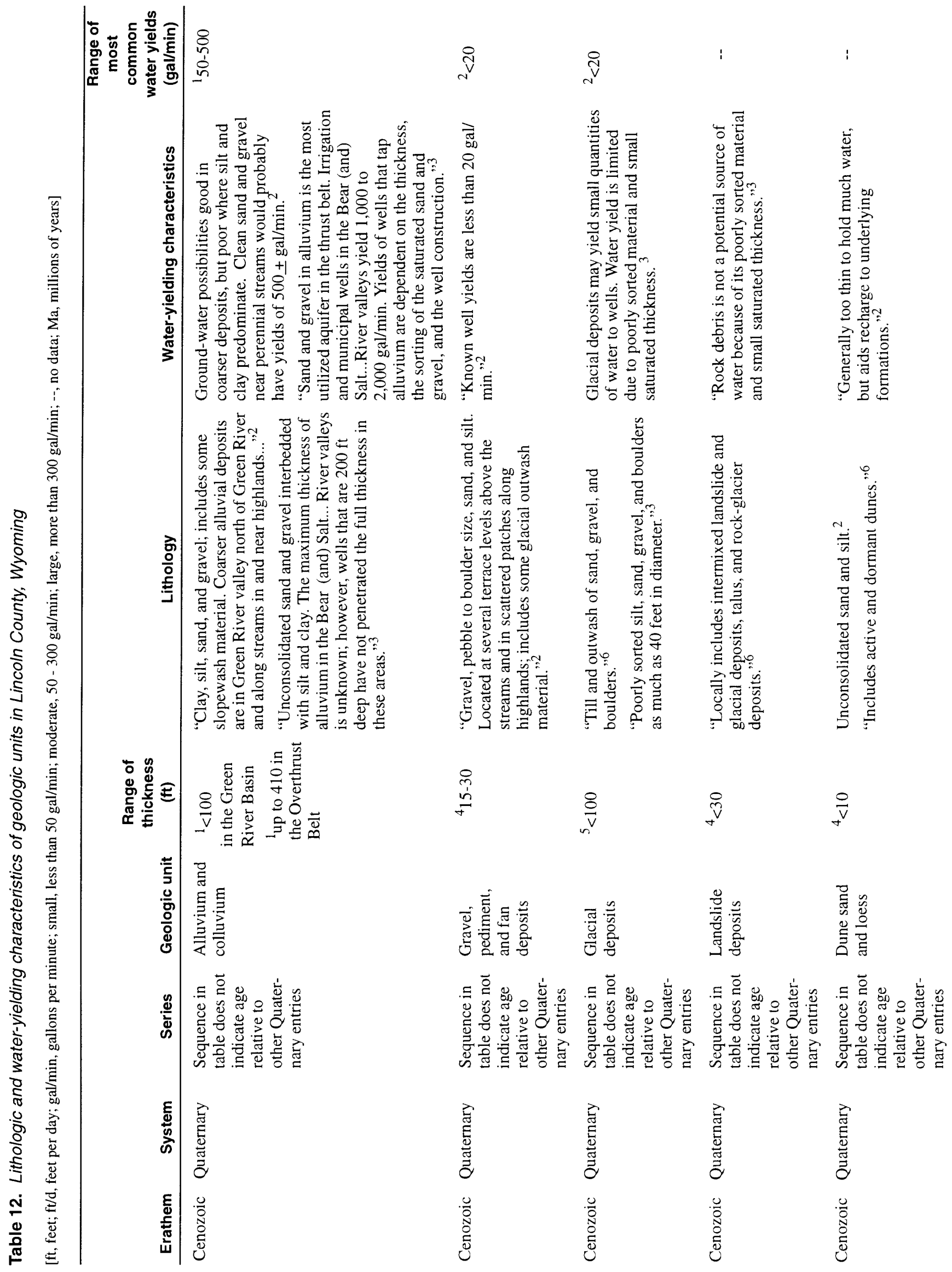




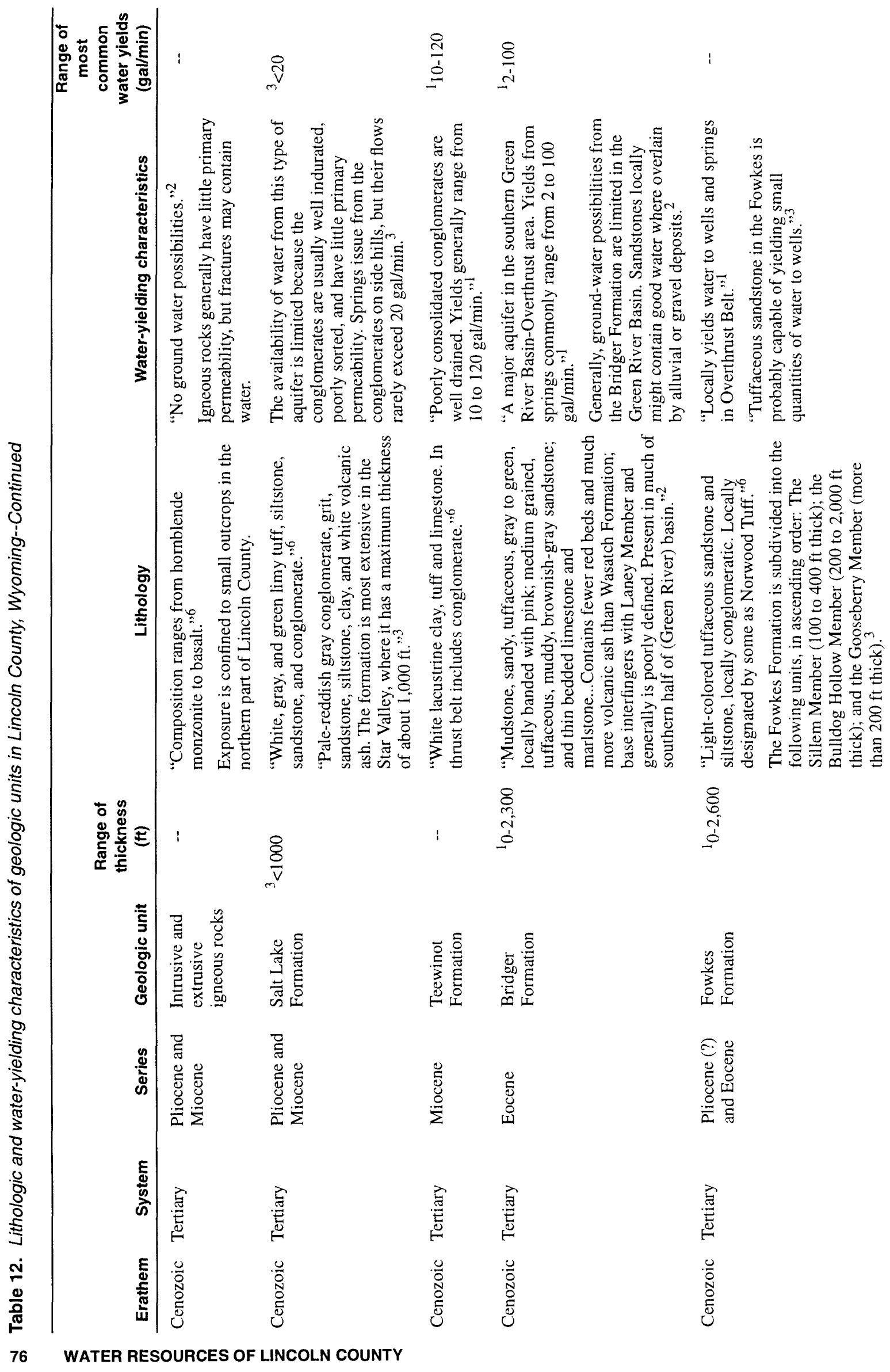




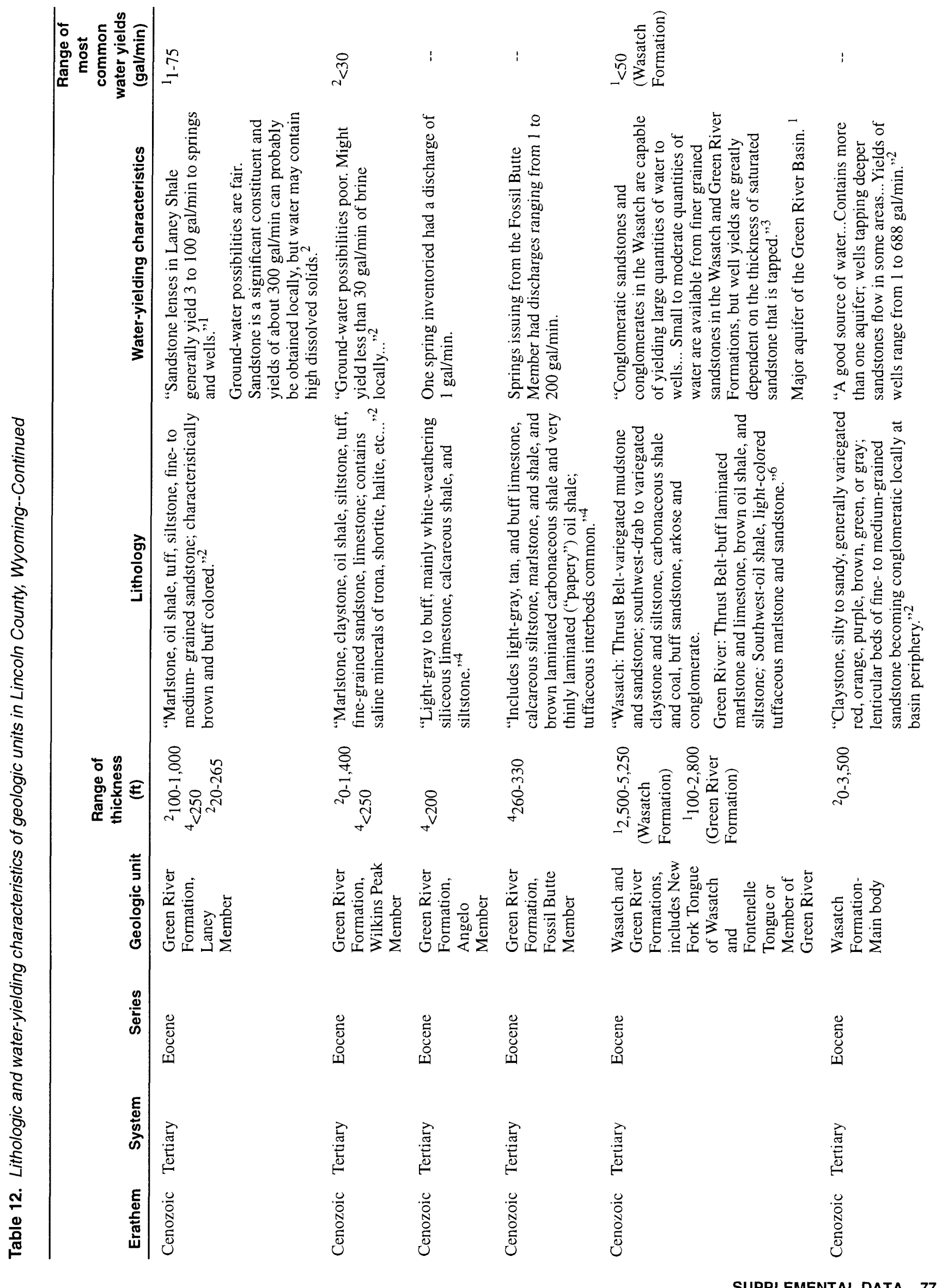




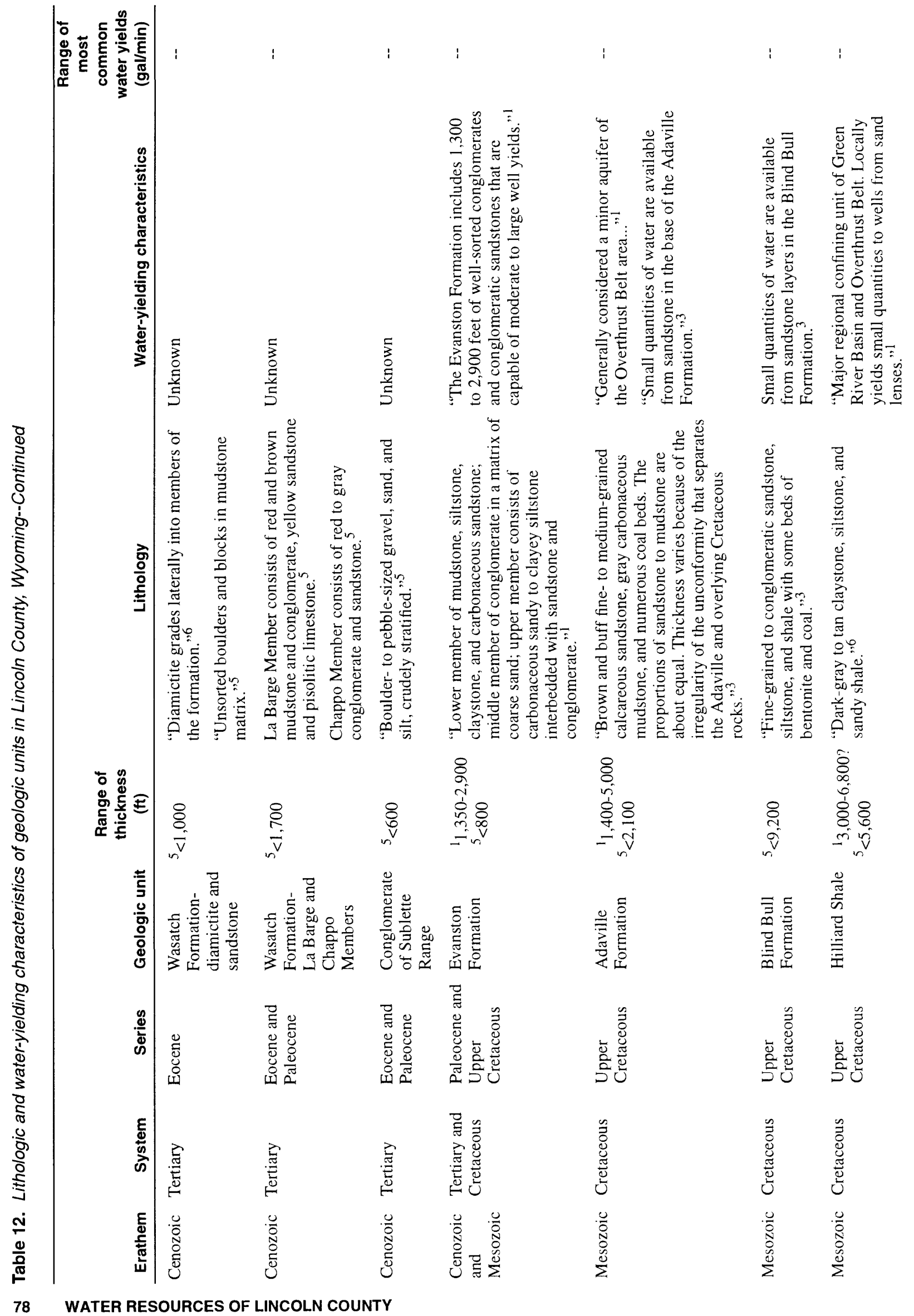




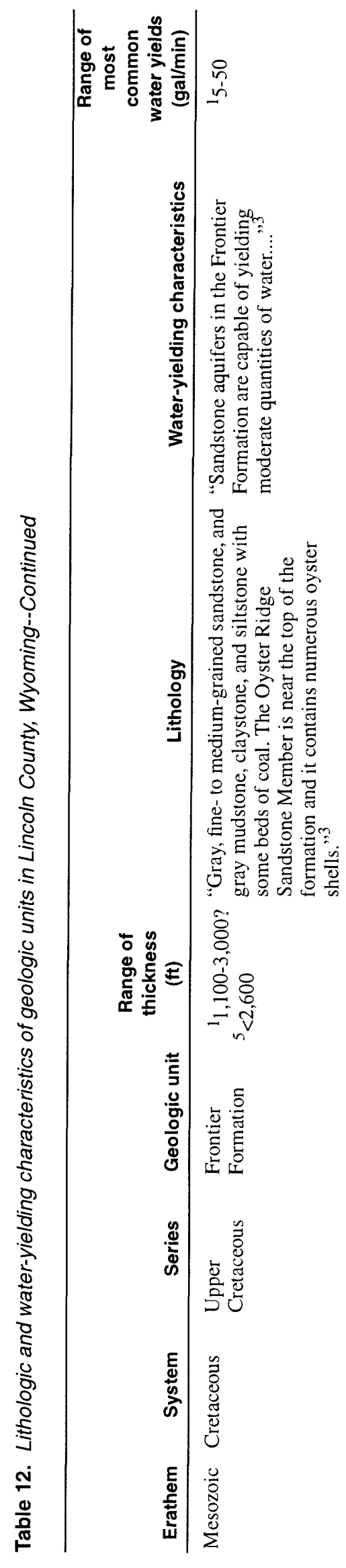

1 in

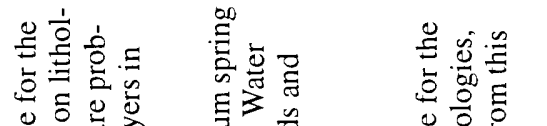

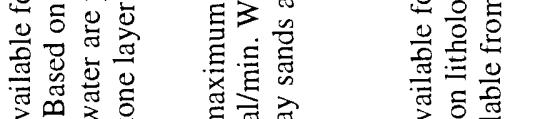

至

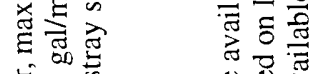

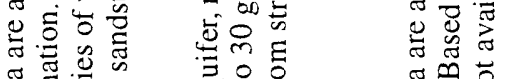

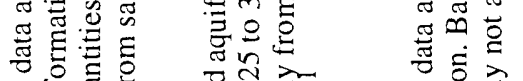

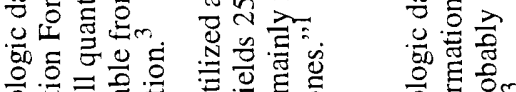

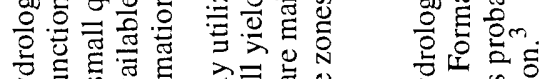

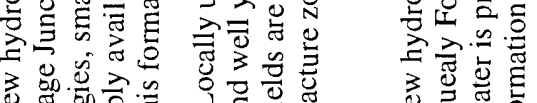

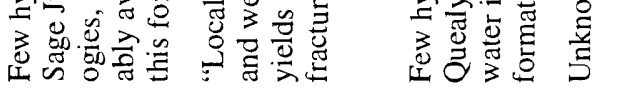

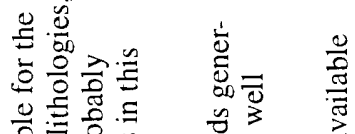

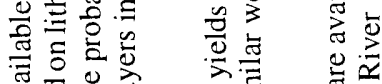

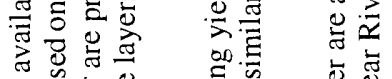

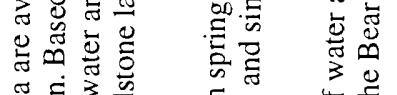

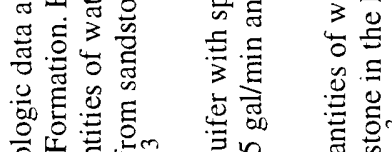

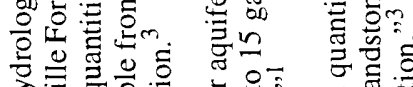

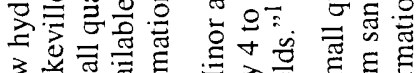

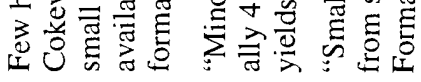

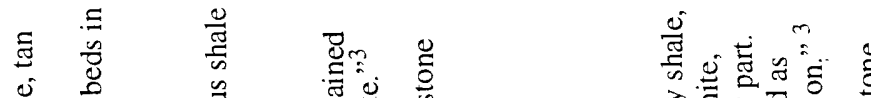

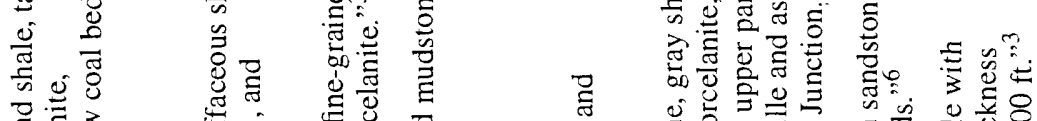

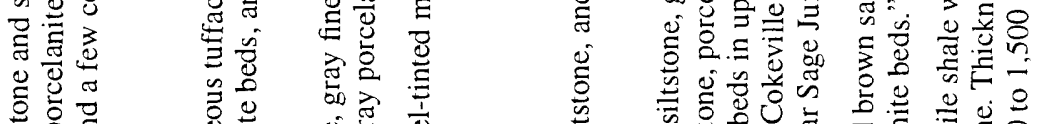

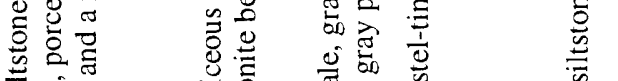

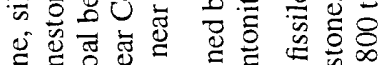

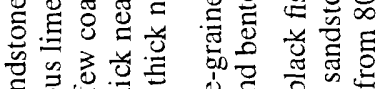

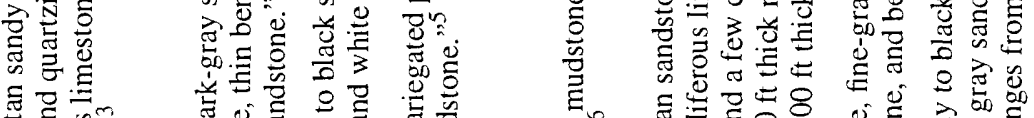

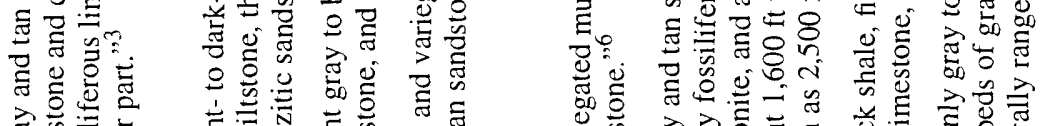

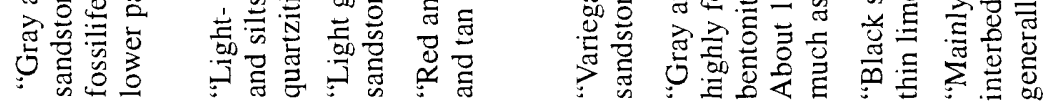

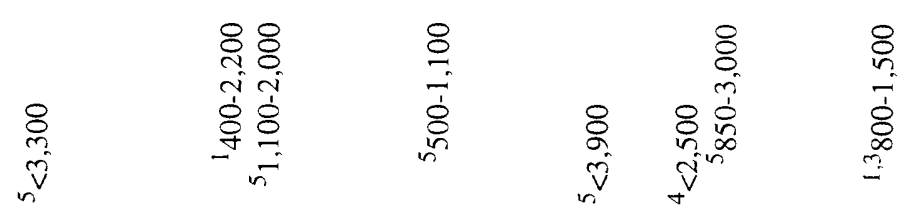

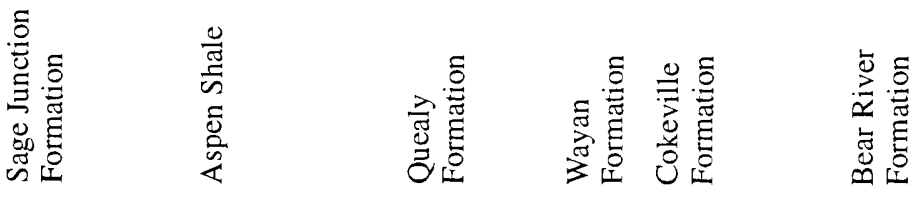

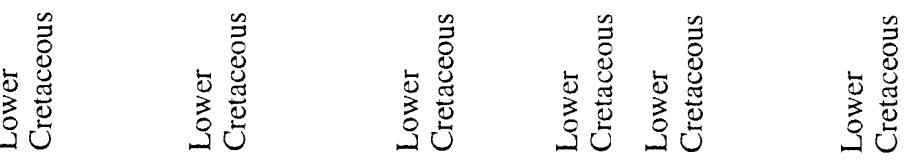

峞

0
0
0
0

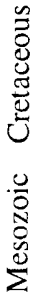

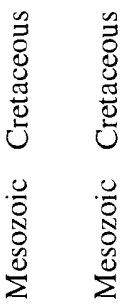

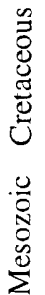




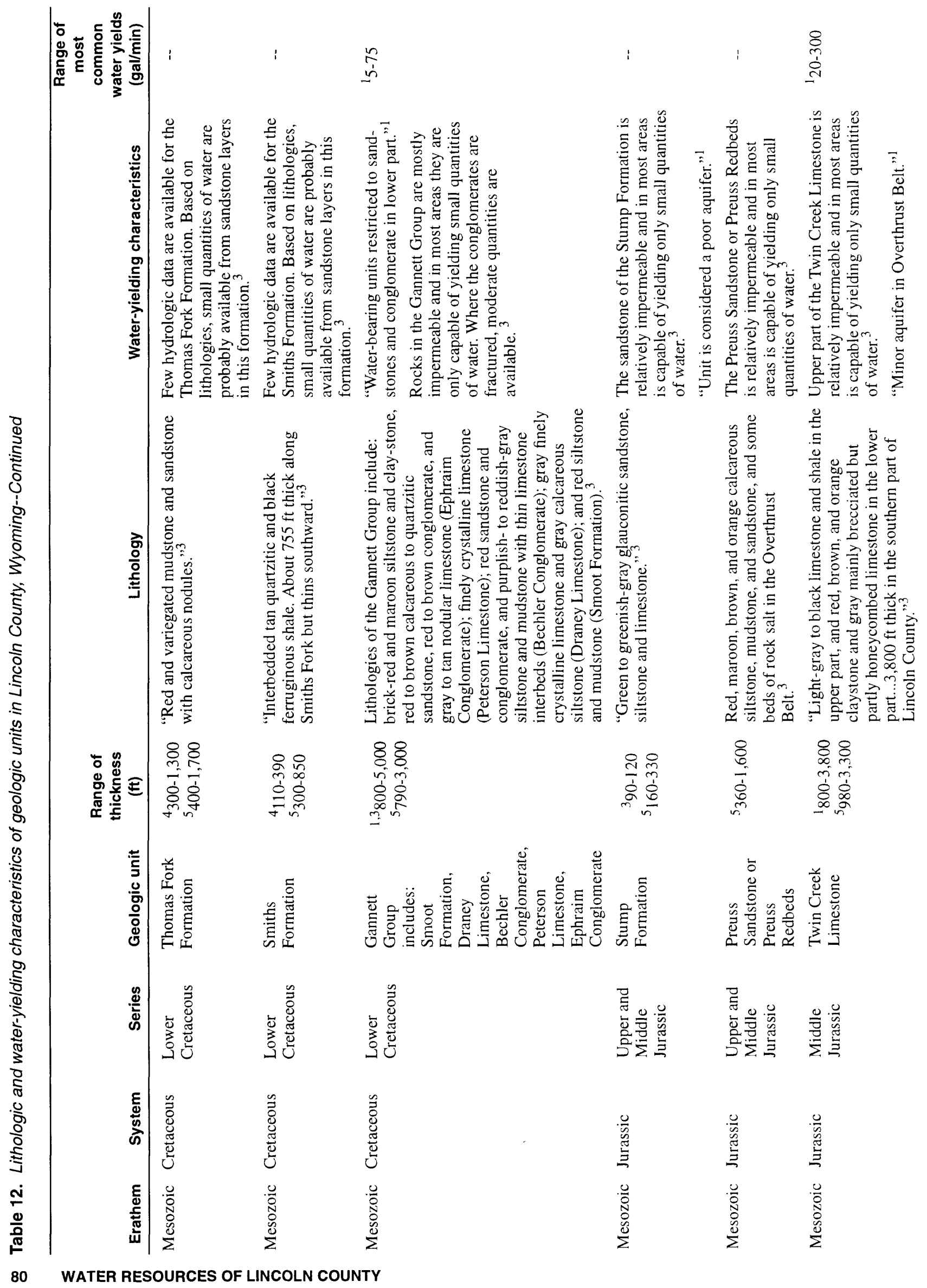




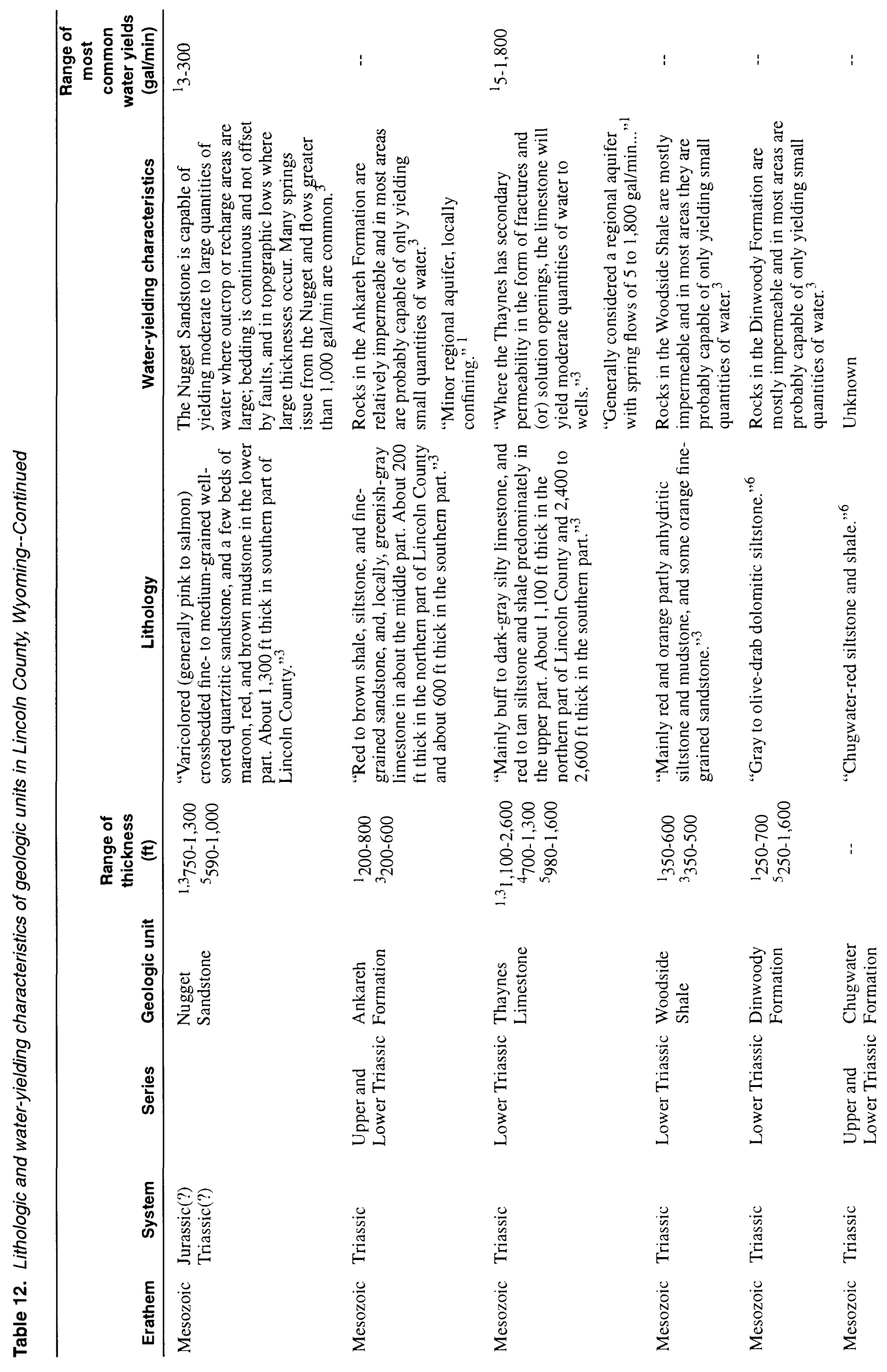




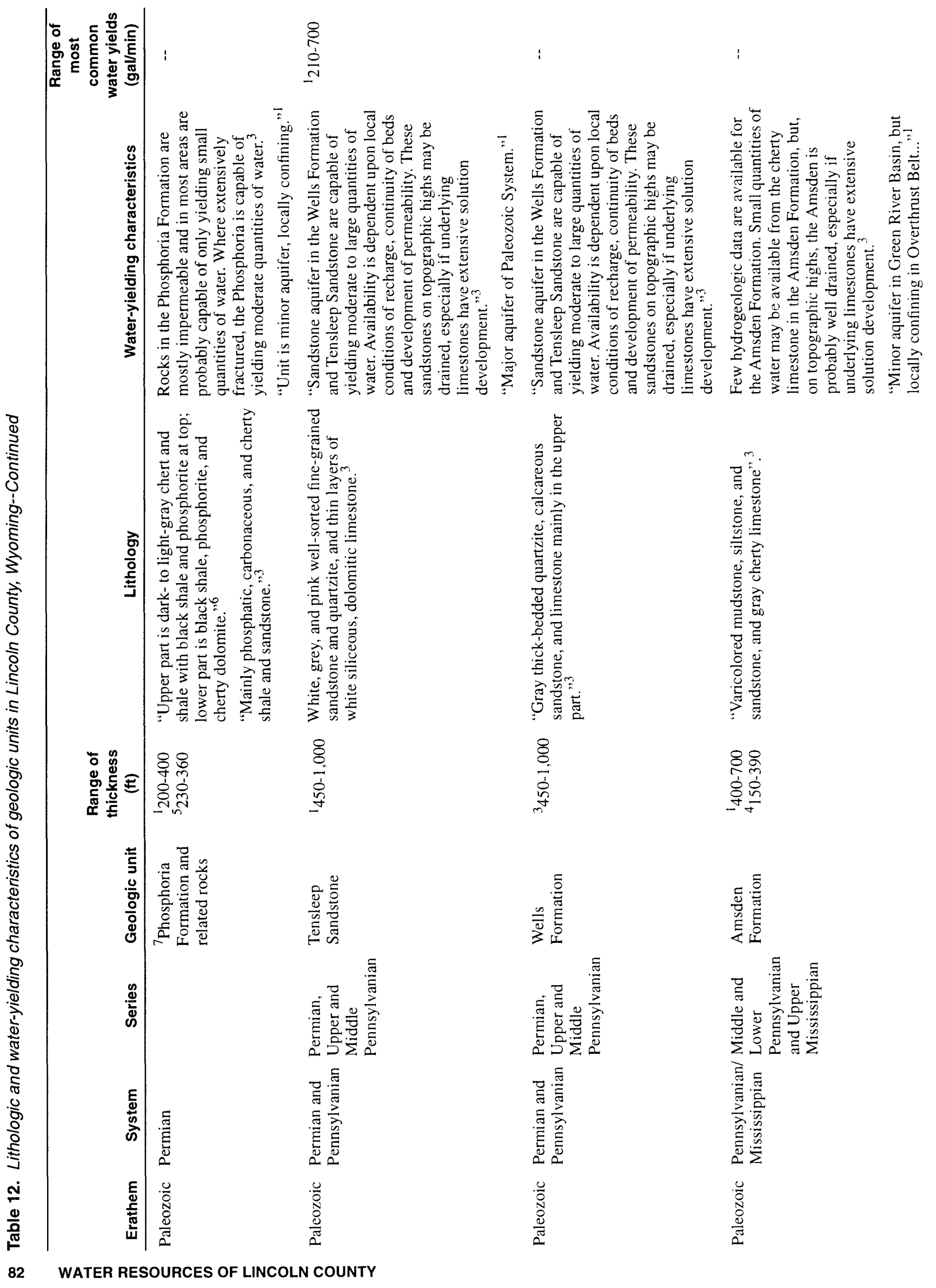




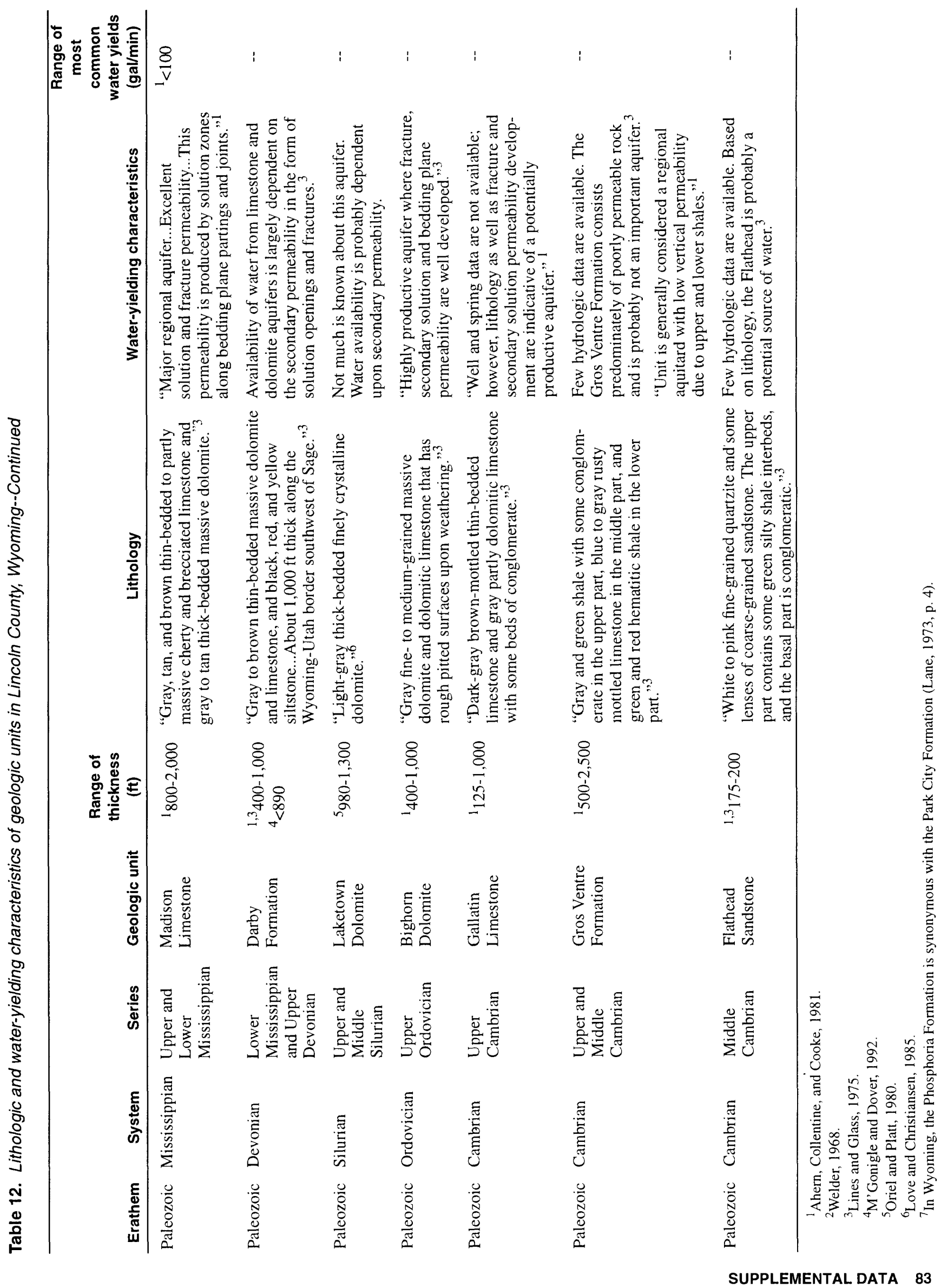




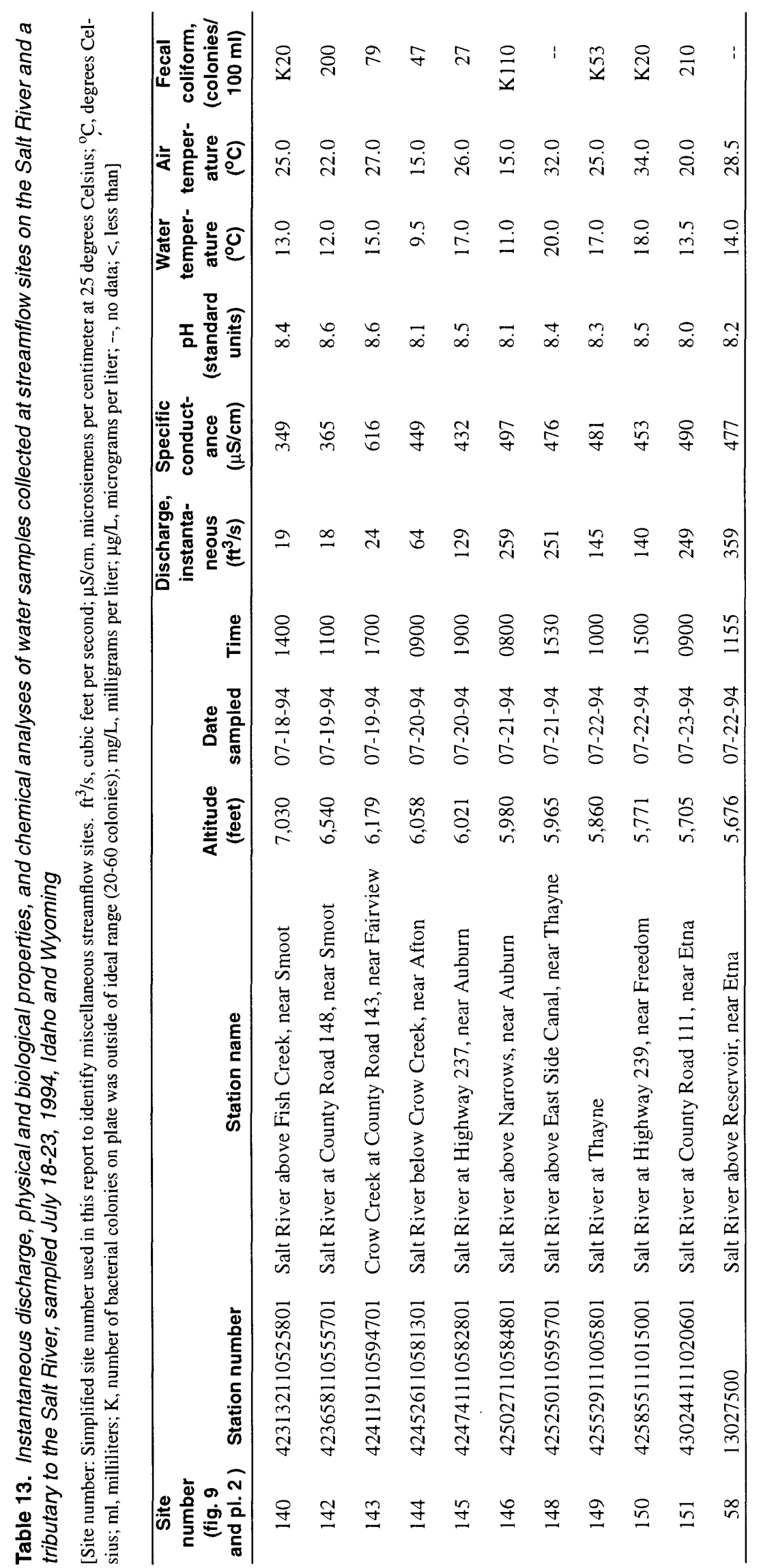




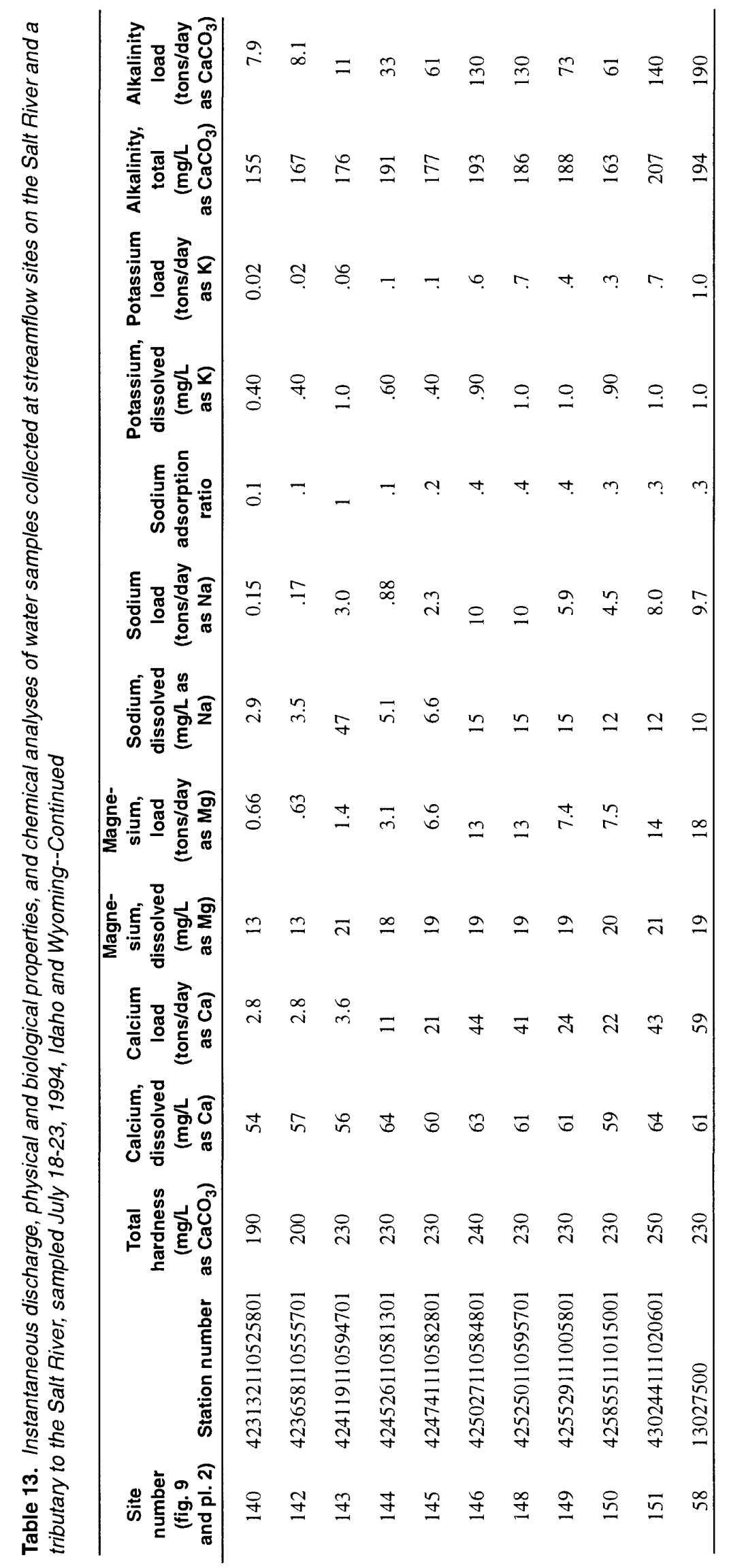




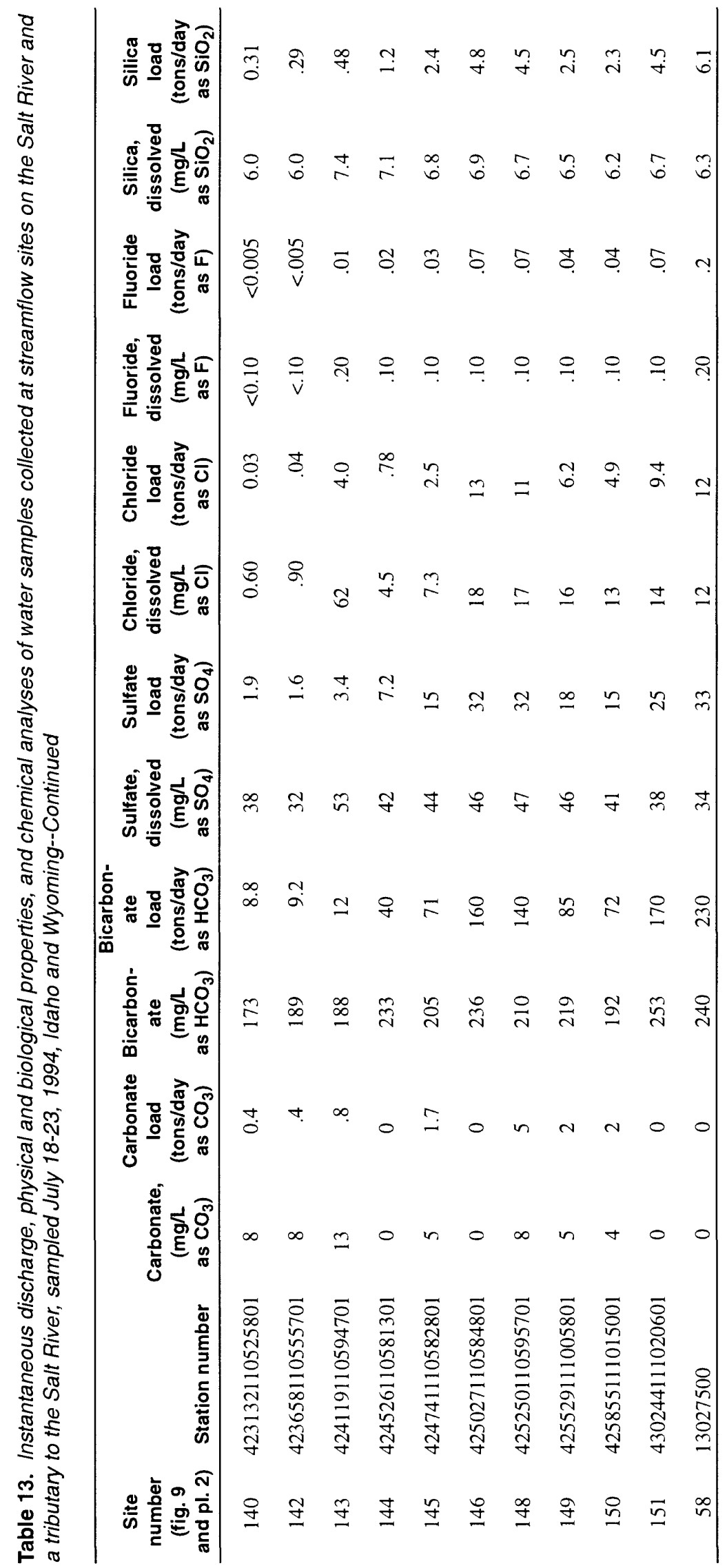




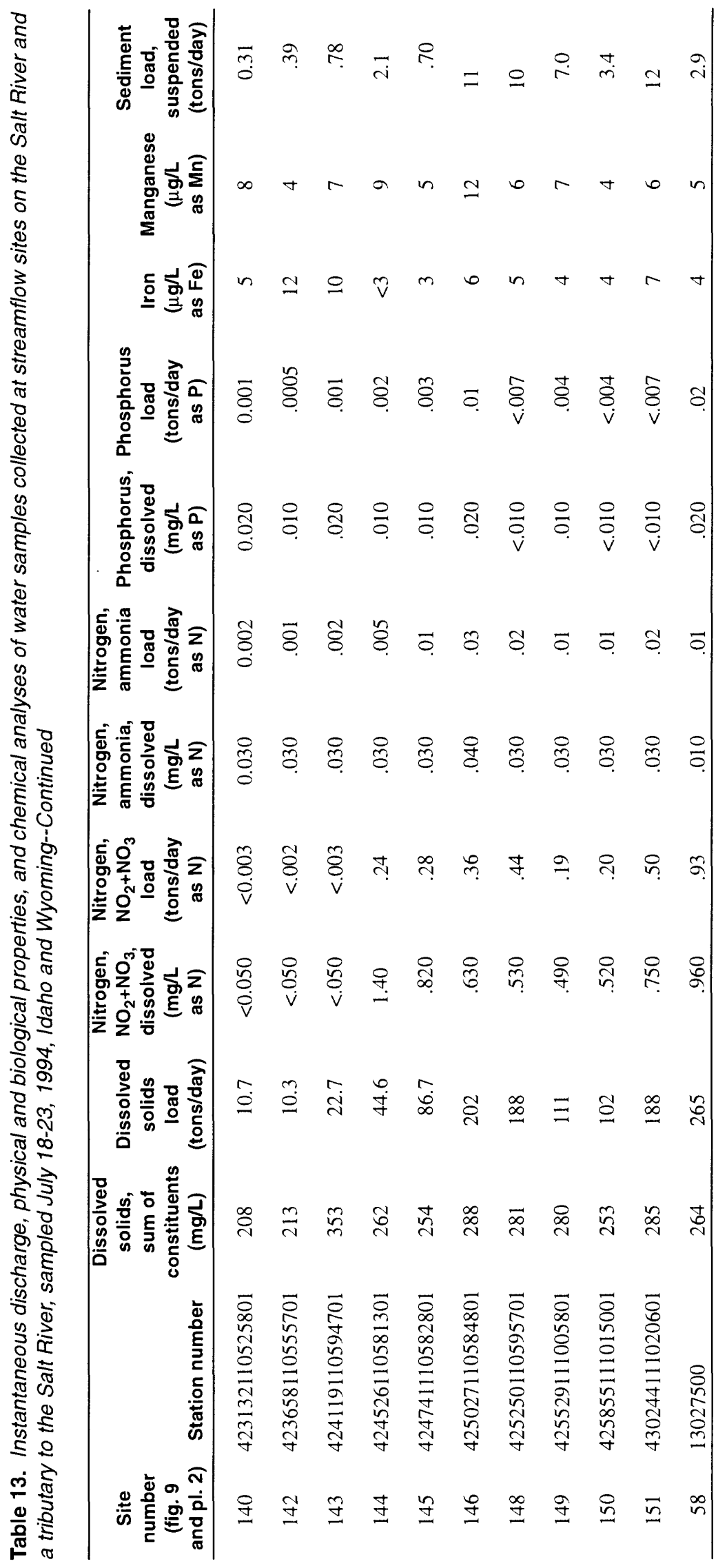


Table 14. Physical properties and chemical analyses of water samples collected from

[Local number: See text describing well-numbering system in the section titled $\mathrm{ft}$, feet below land surface; $\mu \mathrm{S} / \mathrm{cm}$, microsiemens per centimeter at 25 degrees Celsius;

\begin{tabular}{|c|c|c|c|c|c|c|c|c|c|c|}
\hline Station number & $\begin{array}{l}\text { Local number } \\
\text { (pl. 3) }\end{array}$ & $\begin{array}{c}\text { Date } \\
\text { sampled }\end{array}$ & $\begin{array}{c}\text { Well } \\
\text { depth } \\
\text { (ft) }\end{array}$ & $\begin{array}{c}\text { Specific } \\
\text { conduc- } \\
\text { tance } \\
(\mu \mathrm{S} / \mathrm{cm})\end{array}$ & $\begin{array}{c}\mathrm{pH} \\
\text { (stan- } \\
\text { dard } \\
\text { units) } \\
\end{array}$ & $\begin{array}{l}\text { Water } \\
\text { temper- } \\
\text { ature } \\
\left({ }^{\circ} \mathrm{C}\right) \\
\end{array}$ & $\begin{array}{c}\text { Hard- } \\
\text { ness } \\
\text { (as } \\
\left.\mathrm{CaCO}_{3}\right) \\
\end{array}$ & $\begin{array}{l}\text { Calcium, } \\
\text { dissolved } \\
\text { (Ca) }\end{array}$ & $\begin{array}{l}\text { Magne- } \\
\text { sium, } \\
\text { dissolved } \\
(\mathrm{Mg}) \\
\end{array}$ & $\begin{array}{c}\text { Sodium, } \\
\text { dissolved } \\
(\mathrm{Na})\end{array}$ \\
\hline & & & & & & & & & \multicolumn{2}{|c|}{ Quaternary Alluvium } \\
\hline 414152110051001 & 20-112-20cad01 & $07-14-95$ & 25 & 3,100 & 7.4 & 9.0 & 630 & 160 & 55 & 530 \\
\hline 414453110271601 & 20-115-06baa01 & $07-10-95$ & 20 & 622 & 7.2 & 11.0 & 310 & 93 & 19 & 12 \\
\hline 414459110313601 & 21-116-36dcd01 & $07-14-95$ & 105 & 2,470 & 7.3 & 9.0 & 900 & 220 & 86 & 200 \\
\hline 414606110194601 & 21-114-27dac01 & $07-10-95$ & 50 & 2,150 & 8.5 & 11.0 & 26 & 6.7 & 2.2 & 460 \\
\hline 414642110115201 & $21-113-23 \mathrm{dcd} 01$ & $06-25-95$ & 50 & 944 & 8.7 & 9.0 & 37 & 8.7 & 3.7 & 180 \\
\hline 414644111024101 & $21-120-21 \mathrm{ccc} 01$ & $05-18-94$ & 75 & 1,620 & 7.5 & 8.5 & 480 & 98 & 57 & 140 \\
\hline 414645110121101 & $21-113-23 \mathrm{cdc} 01$ & $06-25-95$ & 9 & 579 & 7.5 & 10.0 & 270 & 80 & 18 & 18 \\
\hline 414708110141201 & 21-113-21 acc01 & $06-25-95$ & 55 & 4,140 & 7.4 & 8.0 & 800 & 140 & 110 & 720 \\
\hline 414721110145701 & 21-113-20aad01 & $06-25-95$ & 15 & 1,500 & 7.7 & 10.0 & 230 & 46 & 27 & 250 \\
\hline 414755110573201 & 21-119-08bc01 & $09-22-71$ & 30 & 1,610 & 7.4 & 10.0 & 670 & 150 & 71 & 100 \\
\hline 415050110333401 & 22-116-34aad01 & $08-01-95$ & 80 & 1,760 & 7.4 & 9.5 & 680 & 170 & 61 & 140 \\
\hline 415058110333801 & $22-116-34 a a b 01$ & $08-01-95$ & 50 & 1,360 & 7.6 & 9.5 & 480 & 120 & 43 & 96 \\
\hline 415109110334101 & $22-116-27 \mathrm{ddb} 01$ & $08-01-95$ & 40 & 825 & 7.6 & 7.0 & 310 & 80 & 27 & 43 \\
\hline 415250110361301 & $22-116-17 \mathrm{dcd} 01$ & $06-27-95$ & 15 & 1,180 & 7.2 & 8.0 & 600 & 140 & 60 & 26 \\
\hline 415557110571701 & 23-119-32bda03 & $06-09-95$ & 120 & 767 & 7.6 & 9.0 & 330 & 78 & 32 & 29 \\
\hline 415723110161501 & $23-113-20 \mathrm{ccb} 01$ & $05-25-66$ & Spring & 1,200 & -- & 7.0 & -- & -- & - & -- \\
\hline 415841110563701 & 23-119-16bbb01 & $08-22-89$ & 150 & 1,090 & 7.5 & 14.0 & 410 & 88 & 47 & 75 \\
\hline 420013110560901 & $23-119-04 \mathrm{bcc} 01$ & $06-09-95$ & 200 & 1,540 & 7.6 & 9.0 & 480 & 100 & 56 & 130 \\
\hline 420020110575601 & 23-119-06ad01 & $04-16-56$ & 18 & 503 & 7.5 & 5.5 & 220 & 67 & 14 & 20 \\
\hline 420103110040401 & $24-112-25 \mathrm{dcd} 01$ & $10-18-77$ & Spring & 540 & 8.2 & 13.0 & 190 & 18 & 47 & 40 \\
\hline 420112110325401 & 24-116-35acb01 & $08-01-95$ & 140 & 755 & 8.1 & 7.0 & 49 & 12 & 4.5 & 160 \\
\hline 420253110554601 & 24-119-21 adb01 & $06-10-95$ & 65 & 677 & 7.8 & 10.0 & 280 & 41 & 43 & 39 \\
\hline 420254110555801 & 24-119-21acb01 & $06-10-95$ & 35 & 822 & 7.7 & 10.0 & 320 & 64 & 40 & 49 \\
\hline \multirow[t]{2}{*}{420340110583301} & 24-119-18bdc01 & $06-10-95$ & 249 & 359 & 7.8 & 10.0 & 150 & 40 & 12 & 14 \\
\hline & & $06-10-95$ & 249 & 359 & 7.8 & 10.0 & 150 & 41 & 12 & 15 \\
\hline 420436110561901 & 24-119-09bd01 & $04-16-56$ & 75 & 697 & 8.1 & 8.0 & 320 & 64 & 40 & 29 \\
\hline 420525110401401 & $24-117-03$ dad 01 & $06-27-95$ & 20 & 434 & 7.6 & 5.5 & 220 & 70 & 10 & 7.2 \\
\hline 420552110223301 & 24-114-06abb01 & $07-28-95$ & -- & 1,110 & 7.7 & 9.5 & 210 & 48 & 23 & 170 \\
\hline 420558110133001 & $25-113-35 \mathrm{ddd} 01$ & $07-28-95$ & 75 & 2,750 & 7.5 & 10.0 & 1,400 & 320 & 140 & 160 \\
\hline 420905110111401 & $25-112-17 \mathrm{bcb} 01$ & $07-29-95$ & 60 & 783 & 7.7 & 8.0 & 350 & 99 & 26 & 36 \\
\hline 421115111012701 & 25-119-06bca01 & $06-10-95$ & 60 & 1,080 & 7.7 & 9.0 & 320 & 87 & 25 & 62 \\
\hline
\end{tabular}


wells completed in and springs issuing from selected geologic units in Lincoln County, Wyoming

Ground-Water Data. Analytical results in milligrams per liter except as indicated;

${ }^{\circ} \mathrm{C}$, degrees Celsius; --, no data; <, less than; NE, not established; ND, not detected]

\begin{tabular}{|c|c|c|c|c|c|c|c|c|c|c|c|}
\hline $\begin{array}{c}\text { Sodium } \\
\text { adsorp- } \\
\text { tion } \\
\text { ratio } \\
\end{array}$ & $\begin{array}{l}\text { Potas- } \\
\text { sium, } \\
\text { dissolved } \\
\text { (K) }\end{array}$ & $\begin{array}{r}\text { Bicar- } \\
\text { bonate } \\
\left(\mathrm{HCO}_{3}\right)\end{array}$ & $\begin{array}{c}\text { Car- } \\
\text { bonate } \\
\left(\mathrm{CO}_{3}\right)\end{array}$ & $\begin{array}{l}\text { Alka- } \\
\text { linity, } \\
\text { total as } \\
\left(\mathrm{CaCO}_{3}\right)\end{array}$ & $\begin{array}{c}\text { Sulfate, } \\
\text { dissolved } \\
\left(\mathrm{SO}_{4}\right)\end{array}$ & $\begin{array}{l}\text { Chloride, } \\
\text { dissolved } \\
\text { (CI) }\end{array}$ & $\begin{array}{c}\text { Fluoride, } \\
\text { dissolved } \\
\text { (F) }\end{array}$ & $\begin{array}{c}\text { Silica, } \\
\text { dissolved } \\
\left(\mathrm{SiO}_{2}\right)\end{array}$ & $\begin{array}{l}\text { Dissolved } \\
\text { solids, } \\
\text { sum of } \\
\text { con- } \\
\text { stituents } \\
\end{array}$ & $\begin{array}{c}\text { Nitrogen, } \\
\mathrm{NO}_{2}+\mathrm{NO}_{3} \text {, } \\
\text { dissolved } \\
\text { (as } \mathrm{N} \text { ) }\end{array}$ & $\begin{array}{l}\text { Phos- } \\
\text { phorus, } \\
\text { total } \\
\text { (P) }\end{array}$ \\
\hline \multicolumn{12}{|c|}{ and Colluvium } \\
\hline 9 & 0.6 & -- & -- & 356 & 1,300 & 72 & 1.0 & 13 & 2,350 & 0.630 & $<0.010$ \\
\hline 0.3 & 2.2 & -- & -- & 265 & 60 & 6.2 & 0.20 & 8.0 & 361 & $<.050$ & $<.010$ \\
\hline 3 & 8.1 & -- & -- & 273 & 780 & 210 & .30 & 9.3 & 1,690 & $<.050$ & $<.010$ \\
\hline 39 & 1.4 & -- & -- & 286 & 660 & 57 & .30 & 11 & 1,370 & $<.050$ & .020 \\
\hline 13 & .9 & -- & -- & 200 & 210 & 35 & .70 & 7.4 & 559 & $<.050$ & .020 \\
\hline 3 & 5.1 & -- & -- & 320 & 310 & 160 & .30 & 16 & 960 & - & -- \\
\hline .5 & 1.1 & -- & -- & 225 & 63 & 7.1 & .40 & 8.6 & 342 & $<.050$ & .030 \\
\hline 11 & 1.7 & -- & -- & 359 & 1,700 & 170 & .50 & 8.4 & 3,090 & .730 & .010 \\
\hline 7 & 1.6 & -- & -- & 300 & 400 & 35 & .50 & 8.4 & 962 & .120 & .020 \\
\hline 2 & 3.5 & 400 & 0 & -- & 420 & 87 & .40 & 15 & 1,050 & 1.20 & -- \\
\hline 2 & 2.9 & -- & -- & 292 & 590 & 72 & .30 & 9.9 & 1,220 & .650 & $<.010$ \\
\hline 2 & 3.7 & -- & -- & 263 & 260 & 110 & .20 & 11 & 810 & 1.80 & $<.010$ \\
\hline 1 & 1.9 & -- & -- & 236 & 140 & 15 & .20 & 9.9 & 460 & .310 & $<.010$ \\
\hline .5 & 6.9 & -. & -- & 366 & 260 & 27 & .40 & 10 & 756 & .050 & $<.010$ \\
\hline .7 & 2.7 & -- & -- & 263 & 73 & 45 & .20 & 16 & 437 & -- & -- \\
\hline -- & -- & -- & -- & -- & - & -- & -- & -. & -- & - & -- \\
\hline 2 & 4.1 & -. & -- & 270 & 180 & 84 & .30 & 20 & 666 & 1.30 & -- \\
\hline 3 & 6.6 & -- & -- & 266 & 350 & 120 & .50 & 17 & 938 & -- & -- \\
\hline .6 & -- & 233 & 0 & -- & 29 & 30 & -- & -- & 285 & -- & -- \\
\hline 1 & 1.5 & 170 & 0 & -- & 120 & 4.8 & .40 & 7.1 & 323 & .130 & .010 \\
\hline 10 & 3.1 & -- & -- & 394 & 23 & 1.3 & .50 & 8.3 & 450 & $<.050$ & $<.010$ \\
\hline 1 & 1.5 & -- & -- & 302 & 62 & 6.2 & 1.0 & 23 & 401 & -- & -- \\
\hline 1 & 2.1 & -- & -- & 290 & 110 & 16 & .40 & 26 & 498 & -- & -- \\
\hline .5 & 1.7 & -- & -- & 156 & 8.0 & 14 & .30 & 26 & 210 & -- & -- \\
\hline .5 & 1.7 & -- & -- & 156 & 8.0 & 14 & .30 & 26 & 213 & -- & -- \\
\hline .7 & -- & 328 & 0 & -- & 63 & 33 & -- & -- & 405 & -- & -- \\
\hline .2 & 1.2 & -- & -. & 227 & 17 & 7.1 & .20 & 7.6 & 244 & .090 & .010 \\
\hline 5 & 2.0 & -- & - & 372 & 180 & 30 & .30 & 12 & 689 & $<.050$ & $<.010$ \\
\hline 2 & 6.3 & -- & -- & 262 & 1,300 & 50 & 2.0 & 22 & 2,220 & 15.0 & $<.010$ \\
\hline .8 & 2.0 & -- & -- & 291 & 120 & 7.5 & .10 & 21 & 490 & .750 & $<.010$ \\
\hline 2 & 1.7 & -- & -- & 228 & 46 & 97 & .10 & 18 & 474 & -- & -. \\
\hline
\end{tabular}


Table 14. Physical properties and chemical analyses of water samples collected from

\begin{tabular}{|c|c|c|c|c|c|c|c|c|c|c|}
\hline Station number & $\begin{array}{l}\text { Local number } \\
\text { (pl. 3) }\end{array}$ & $\begin{array}{c}\text { Date } \\
\text { sampled }\end{array}$ & $\begin{array}{c}\text { Well } \\
\text { depth } \\
\text { (ft) }\end{array}$ & $\begin{array}{c}\text { Specific } \\
\text { conduc- } \\
\text { tance } \\
(\mu \mathrm{S} / \mathrm{cm})\end{array}$ & $\begin{array}{c}\text { pH } \\
\text { (stan- } \\
\text { dard } \\
\text { units) }\end{array}$ & $\begin{array}{l}\text { Water } \\
\text { temper- } \\
\text { ature } \\
\left({ }^{\circ} \mathrm{C}\right)\end{array}$ & $\begin{array}{l}\text { Hard- } \\
\text { ness } \\
\text { (as } \\
\left.\mathrm{CaCO}_{3}\right)\end{array}$ & $\begin{array}{l}\text { Calcium, } \\
\text { dissolved } \\
\text { (Ca) }\end{array}$ & $\begin{array}{l}\text { Magne- } \\
\text { sium, } \\
\text { dissolved } \\
(\mathrm{Mg})\end{array}$ & $\begin{array}{l}\text { Sodium, } \\
\text { dissolved } \\
\text { (Na) }\end{array}$ \\
\hline & & & & & & & & & \multicolumn{2}{|c|}{ Quaternary Alluvium } \\
\hline 421154110095801 & 26-112-33bba01 & $08-20-76$ & 10 & 700 & -- & 17.0 & 370 & 94 & 33 & 18 \\
\hline 421155110100301 & 26-112-33bba02 & $08-20-76$ & 1 & 700 & -- & 16.5 & 350 & 86 & 32 & 15 \\
\hline 421245110113001 & 26-112-30abc01 & $07-27-95$ & 75 & 683 & 7.7 & 9.0 & 280 & 74 & 24 & 37 \\
\hline 421247111024601 & $26-120-25 \mathrm{cba} 01$ & 06-09-95 & 210 & 729 & 7.6 & 9.0 & 350 & 82 & 36 & 12 \\
\hline 421252110113601 & $26-112-19 \mathrm{dcd} 01$ & $07-27-95$ & 100 & 664 & 7.7 & 9.0 & 160 & 32 & 20 & 88 \\
\hline \multirow[t]{2}{*}{421259110102901} & 26-112-20ddb01 & $08-20-76$ & 75 & 560 & -- & 18.0 & 280 & 74 & 22 & 18 \\
\hline & & $08-12-89$ & 75 & 620 & 6.7 & 11.5 & 290 & 80 & 22 & 8.4 \\
\hline 421301111023201 & 26-120-25bda01 & 06-09-95 & 90 & 517 & 7.7 & 9.0 & 230 & 52 & 25 & 13 \\
\hline 421500110122001 & 23-113-0201 & $05-27-58$ & Spring & 1,280 & 7.5 & 6.5 & 570 & 120 & 66 & 91 \\
\hline 421630111015501 & 26-120-01bb01 & $09-21-71$ & 185 & 605 & 7.5 & 7.0 & 320 & 82 & 27 & 8.6 \\
\hline $423238110533201^{1}$ & 30-118-33bcb01 & $10-07-93$ & 85 & 431 & 7.7 & 8.0 & 230 & 72 & 11 & 2.8 \\
\hline 423610110544601 & 30-118-08bbc01 & $07-29-92$ & 130 & 493 & 7.5 & 11.5 & -- & -- & -- & -- \\
\hline 423620110554000 & $30-119-12 \mathrm{ac} 00$ & $09-21-71$ & 140 & 408 & 7.5 & 9.5 & 190 & 55 & 12 & 11 \\
\hline 423710110544601 & 30-118-05bbb01 & $07-28-92$ & 98 & 427 & 7.8 & 6.0 & -- & -- & -- & -- \\
\hline 423714110544401 & $31-118-32 \operatorname{ccc} 01$ & 08-03-94 & 88 & 440 & 7.9 & 5.0 & 220 & 65 & 15 & 2.2 \\
\hline 423714110545001 & 31-118-31ddd01 & $07-28-92$ & 98 & 427 & 7.6 & 6.0 & -- & -- & -- & -- \\
\hline 423748110551500 & $31-118-31$ ac01 & $09-14-71$ & 45 & 412 & 7.5 & 7.5 & 220 & 65 & 13 & 2.3 \\
\hline 423756110571201 & 31-119-35aad01 & $07-29-92$ & - & 492 & 7.5 & 9.0 & -- & -- & -- & -- \\
\hline 423838110551401 & $31-118-30 \operatorname{arc} 01$ & 08-04-94 & 262 & 425 & 7.7 & 8.0 & 220 & 64 & 15 & 2.9 \\
\hline 423949110552501 & 31-118-19baa01 & $07-28-92$ & -- & 421 & 7.7 & 10.5 & -- & -- & -- & -- \\
\hline 424006110591601 & $31-119-15 \operatorname{cbd} 01$ & $07-29-92$ & 65 & 559 & 7.6 & 9.0 & -- & -- & -- & -- \\
\hline 424043110580001 & $31-119-11 \mathrm{cdc} 01$ & $07-28-92$ & 148 & 398 & 7.6 & 10.0 & -- & -- & -- & -- \\
\hline 424128110585301 & $31-119-10 a b c 01$ & 08-23-89 & 120 & 545 & 7.2 & 10.0 & 270 & 83 & 16 & 4.9 \\
\hline 424132110575501 & 31-119-11bab01 & $07-28-92$ & 112 & 424 & 7.6 & 9.5 & -. & -- & -- & -- \\
\hline 424133110574301 & $31-119-11 \mathrm{abb} 01$ & 08-03-94 & 107 & 375 & 7.8 & 9.0 & 190 & 55 & 13 & 2.3 \\
\hline 424139110585601 & 31-119-03cdd01 & $07-27-92$ & 70 & 532 & 7.3 & 9.5 & -- & -- & -- & -- \\
\hline 424215110585201 & $31-119-03 a b c 01$ & $07-27-92$ & 60 & 538 & 7.4 & 10.5 & -- & -- & -- & - \\
\hline $424216110585501^{1}$ & 31-119-03bad01 & $10-06-93$ & 70 & 543 & 7.6 & 9.0 & 260 & 77 & 16 & 11 \\
\hline $424423110570901^{1}$ & 32-119-23dad01 & $10-08-93$ & 75 & 340 & 8.0 & 5.0 & 180 & 48 & 14 & 1.0 \\
\hline 424520111014000 & 32-119-05bb01 & $09-10-71$ & 35 & 788 & 7.4 & 8.5 & 320 & 94 & 20 & 33 \\
\hline 424521110594701 & $32-119-16 \mathrm{dac} 01$ & 08-04-94 & 70 & 599 & 7.5 & 10.0 & 250 & 77 & 14 & 26 \\
\hline
\end{tabular}




\begin{tabular}{|c|c|c|c|c|c|c|c|c|c|c|c|}
\hline $\begin{array}{c}\text { Sodium } \\
\text { adsorp- } \\
\text { tion } \\
\text { ratio } \\
\end{array}$ & $\begin{array}{c}\text { Potas- } \\
\text { sium, } \\
\text { dissolved } \\
(\mathbf{K})\end{array}$ & $\begin{array}{r}\text { Bicar- } \\
\text { bonate } \\
\left(\mathrm{HCO}_{3}\right)\end{array}$ & $\begin{array}{c}\text { Car- } \\
\text { bonate } \\
\left(\mathrm{CO}_{3}\right)\end{array}$ & $\begin{array}{c}\text { Alka- } \\
\text { linity, } \\
\text { total as } \\
\left(\mathrm{CaCO}_{3}\right)\end{array}$ & $\begin{array}{l}\text { Sulfate, } \\
\text { dissolved } \\
\left(\mathrm{SO}_{4}\right)\end{array}$ & $\begin{array}{c}\text { Chloride, } \\
\text { dissolved } \\
\text { (CI) }\end{array}$ & $\begin{array}{c}\text { Fluoride, } \\
\text { dissolved } \\
\text { (F) }\end{array}$ & $\begin{array}{c}\text { Silica, } \\
\text { dissolved } \\
\left(\mathrm{SiO}_{2}\right) \\
\end{array}$ & $\begin{array}{l}\text { Dissolved } \\
\text { solids, } \\
\text { sum of } \\
\text { con- } \\
\text { stituents } \\
\end{array}$ & $\begin{array}{c}\text { Nitrogen, } \\
\mathrm{NO}_{2}+\mathrm{NO}_{3}, \\
\text { dissolved } \\
\text { (as } \mathrm{N})\end{array}$ & $\begin{array}{c}\text { Phos- } \\
\text { phorus, } \\
\text { total } \\
(P)\end{array}$ \\
\hline \multicolumn{12}{|c|}{ and Colluvium--Continued } \\
\hline 0.4 & 2.5 & -- & - & 355 & 56 & 4.8 & 0.60 & 18 & 428 & $<0.100$ & 0.010 \\
\hline .4 & 2.5 & -- & -- & 311 & 74 & 3.9 & .50 & 18 & 418 & .010 & .010 \\
\hline 1 & 1.1 & -- & -- & 244 & 110 & 6.7 & .30 & 11 & 411 & .100 & $<.010$ \\
\hline .3 & 1.5 & -- & -- & 190 & 170 & 13 & .10 & 18 & 458 & 2.80 & .010 \\
\hline 3 & 1.6 & -- & -- & 240 & 110 & 6.4 & .30 & 13 & 416 & .130 & $<.010$ \\
\hline .5 & 1.3 & -- & -- & -. & 58 & 4.2 & .40 & 9.8 & 342 & .270 & $<.010$ \\
\hline .2 & .7 & -- & -- & 220 & 6 & 4.0 & .40 & 10 & 324 & $<.100$ & -- \\
\hline .4 & 1.3 & -- & -- & 190 & 51 & 11 & .10 & 15 & 284 & -- & -. \\
\hline 2 & -- & 356 & 0 & -- & 430 & 20 & -- & 22 & 928 & -- & -- \\
\hline .2 & 1.1 & -- & -- & 218 & 110 & 3.9 & .20 & 12 & 383 & 1.70 & -- \\
\hline .1 & .7 & -- & -. & 207 & 29 & .9 & .10 & 7.9 & 250 & .300 & .010 \\
\hline-- & -- & -- & -- & -- & -- & - & -- & -- & - & -- & -- \\
\hline .4 & 1.1 & -- & -- & 182 & 43 & 2.7 & .20 & 20 & 255 & .280 & -- \\
\hline -- & -- & -- & -- & -- & -- & -- & -- & -- & -- & -- & -- \\
\hline .1 & .4 & -- & -- & 157 & 73 & .9 & .20 & 6.6 & 263 & .980 & $<.010$ \\
\hline -- & -- & -- & -- & -- & -- & -- & -- & -- & -- & -- & -- \\
\hline .1 & .8 & -- & -- & 186 & 43 & 1.6 & 0 & 8.1 & 247 & .460 & -- \\
\hline-- & -- & -- & - & -- & -- & -- & -- & -- & -- & -- & -- \\
\hline .1 & .5 & -- & -- & 160 & 42 & 1.7 & .10 & 8.5 & 249 & 1.20 & $<.010$ \\
\hline-- & -. & -- & -- & -- & -- & -- & -- & -- & -- &.- & -- \\
\hline -- & -- & -- & -- & -- & -- & -- & -- & -- & -- & -- & -- \\
\hline -- & -- & -- & -- & - & -- & -- & -- & -- & -- & -- & -- \\
\hline .1 & 1.0 & -- & -- & 220 & 42 & 4.9 & .20 & 13 & 312 & 3.50 & -- \\
\hline -. & -- & -- & -- & -- & -- & -- & -- & -- & -- & -- & -- \\
\hline .1 & .6 & -- & -- & 168 & 30 & 1.0 & .20 & 7.3 & 213 & .630 & .010 \\
\hline-- & -- & -- & -- & -- & - & -- & -- & -- & -- & -- & -- \\
\hline -- & -- & -- & -- & -- & -- & -- & -- & -- & -- & -- & -- \\
\hline .3 & 1.1 & -- & -- & 224 & 34 & 15 & .20 & 11 & 313 & 2.50 & $<.010$ \\
\hline 0 & .7 & -- & -- & 150 & 39 & .3 & .30 & 4.8 & 196 & .250 & $<.010$ \\
\hline .8 & 4.1 & -- & -- & 276 & 24 & 73 & .20 & 14 & 433 & 1.20 & -- \\
\hline .7 & 1.3 & -- & -- & 221 & 26 & 34 & .20 & 14 & 343 & 3.70 & .090 \\
\hline
\end{tabular}


Table 14. Physical properties and chemical analyses of water samples collected from

\begin{tabular}{|c|c|c|c|c|c|c|c|c|c|c|}
\hline Station number & $\begin{array}{c}\text { Local number } \\
\text { (pl. 3) }\end{array}$ & $\begin{array}{c}\text { Date } \\
\text { sampled }\end{array}$ & $\begin{array}{l}\text { Well } \\
\text { depth } \\
\text { (ft) }\end{array}$ & $\begin{array}{c}\text { Specific } \\
\text { conduc- } \\
\text { tance } \\
(\mu \mathrm{S} / \mathrm{cm})\end{array}$ & $\begin{array}{c}\text { pH } \\
\text { (stan- } \\
\text { dard } \\
\text { units) } \\
\end{array}$ & $\begin{array}{c}\text { Water } \\
\text { temper- } \\
\text { ature } \\
\left({ }^{\circ} \mathrm{C}\right) \\
\end{array}$ & $\begin{array}{c}\text { Hard- } \\
\text { ness } \\
\text { (as } \\
\left.\mathrm{CaCO}_{3}\right) \\
\end{array}$ & $\begin{array}{c}\text { Calcium, } \\
\text { dissolved } \\
\text { (Ca) }\end{array}$ & $\begin{array}{l}\text { Magne- } \\
\text { sium, } \\
\text { dissolved } \\
(\mathrm{Mg})\end{array}$ & $\begin{array}{c}\text { Sodium, } \\
\text { dissolved } \\
(\mathrm{Na})\end{array}$ \\
\hline & & & & & & & & & \multicolumn{2}{|c|}{ Quaternary Alluvium } \\
\hline 424542110555801 & 32-119-13ada01 & $07-27-92$ & 73 & 412 & 7.7 & 7.5 & -- & -- & -- & -- \\
\hline 424640110555000 & $33-118-32 \mathrm{da} 00$ & $09-10-71$ & 146 & 499 & 7.6 & 9.0 & 260 & 83 & 14 & 2.8 \\
\hline $424740110572601^{1}$ & $33-118-31 \mathrm{ddc} 01$ & $10-06-93$ & 50 & 453 & 7.7 & 9.0 & 240 & 71 & 15 & 2.0 \\
\hline 424756110594801 & 33-119-35dac01 & 08-04-94 & 65 & 926 & 7.8 & 8.0 & 230 & 62 & 18 & 97 \\
\hline 424806110594701 & 33-119-35adc01 & 08-04-94 & 28 & 784 & 7.8 & 7.0 & 210 & 58 & 16 & 83 \\
\hline 424851110572801 & 33-118-30dba01 & $07-25-92$ & 80 & 540 & 7.4 & 9.0 & -- & -- & -- & -- \\
\hline 424910110574401 & $33-118-30 a b c 01$ & $07-25-92$ & 70 & 413 & 7.4 & 9.0 & -- & -- & -- & -- \\
\hline 424926110595001 & $33-119-23 \mathrm{dcd} 01$ & $07-29-92$ & 40 & 623 & 7.4 & 10.5 & -- & -- & - & -- \\
\hline 425053110563201 & 33-118-17acb01 & $07-27-92$ & -- & 652 & 7.3 & 8.0 & - & -- & -- & -- \\
\hline 425107110533501 & $33-118-11 \operatorname{ccc} 01$ & $07-27-92$ & 105 & 394 & 7.8 & 7.5 & -- & -- & -- & -- \\
\hline 425110110590000 & $33-119-12 \mathrm{~cd} 01$ & $09-10-71$ & 30 & 529 & 7.4 & 9.0 & 290 & 83 & 19 & 2.5 \\
\hline 425127110592701 & $33-119-12$ cba02 & 08-06-94 & 33 & 554 & 7.6 & 9.0 & 250 & 66 & 21 & 18 \\
\hline $425135110592201^{1}$ & $33-119-12 \mathrm{cba} 01$ & $10-06-93$ & 25 & 536 & 7.7 & 9.0 & 270 & 65 & 25 & 9.4 \\
\hline 425200110591000 & 33-119-12bab01 & $09-10-71$ & 32 & 567 & 7.5 & 7.5 & 250 & 73 & 16 & 12 \\
\hline 425228110585301 & 33-119-01 acc01 & $07-26-92$ & 160 & 1,380 & 7.2 & 9.0 & -- & -- & -- & -- \\
\hline 425324110575201 & 34-118-31bdd01 & $07-28-92$ & - & 317 & 8.0 & 5.0 & -- & -- & -- & -- \\
\hline 425327110580701 & 34-118-31bca01 & $07-27-92$ & -- & 303 & 8.1 & 7.5 & -- & -- & - & -- \\
\hline 425438110555701 & $34-118-21 \mathrm{ccc} 01$ & $07-27-92$ & -- & 375 & 7.9 & 7.5 & -- & -- & -- & -- \\
\hline 425527111010401 & 34-119-22aba01 & $07-27-92$ & -- & 587 & 7.5 & 10.0 & -- & -- & -- & -- \\
\hline \multirow[t]{2}{*}{425540110581801} & $34-118-18 \mathrm{ccb} 01$ & $07-27-92$ & 70 & 417 & 7.8 & 8.5 & -- & -- & -- & -- \\
\hline & & $10-05-93$ & 70 & 520 & 7.7 & 10.0 & 220 & 54 & 21 & 0.9 \\
\hline 425555111013301 & $34-119-15 \mathrm{cab} 01$ & 08-05-94 & 56 & 693 & 7.3 & 8.0 & 330 & 99 & 21 & 17 \\
\hline 425617110582001 & 34-119-13aaa01 & $07-28-92$ & -- & 408 & 7.7 & 8.0 & -- & -- & -- & -- \\
\hline $425638111002201^{1}$ & 34-119-11 cac01 & $10-07-93$ & 60 & 427 & 7.7 & 8.0 & 230 & 55 & 22 & 1.3 \\
\hline 425650110584000 & 34-119-12ac01 & $09-10-71$ & 169 & 381 & 7.5 & 13.0 & 200 & 45 & 21 & 1.5 \\
\hline 425759111003901 & 34-119-02bbb01 & $08-24-89$ & 130 & 313 & 7.7 & 12.0 & 120 & 35 & 8.3 & 20 \\
\hline 425843111023501 & 35-119-33bda01 & 08-06-94 & 50 & 593 & 7.5 & 7.5 & 290 & 80 & 21 & 13 \\
\hline $425855111020601^{1}$ & 35-119-33abb01 & $10-08-93$ & 50 & 499 & 7.7 & 8.0 & 230 & 63 & 18 & 13 \\
\hline $425857110591901^{1}$ & $35-119-25 \mathrm{ccd} 01$ & $07-25-92$ & 119 & 384 & 7.8 & 9.0 & -- & -- & -- & -- \\
\hline \multirow[t]{2}{*}{425857111021801} & 35-119-33aba01 & 08-05-94 & 60 & 540 & 7.7 & 8.0 & 260 & 70 & 20 & 14 \\
\hline & & $10-16-94$ & 60 & 530 & 7.6 & 8.5 & 240 & 68 & 18 & 13 \\
\hline 425903111022400 & $35-119-28 \mathrm{dcc} 00$ & $09-10-71$ & 31 & 529 & 7.5 & 10.0 & 270 & 77 & 18 & 11 \\
\hline
\end{tabular}


wells completed in and springs issuing from selected geologic units in Lincoln County, Wyoming--Continued

\begin{tabular}{|c|c|c|c|c|c|c|c|c|c|c|c|}
\hline $\begin{array}{c}\text { Sodium } \\
\text { adsorp- } \\
\text { tion } \\
\text { ratio } \\
\end{array}$ & $\begin{array}{c}\text { Potas- } \\
\text { sium, } \\
\text { dissolved } \\
\text { (K) }\end{array}$ & $\begin{array}{r}\text { Bicar- } \\
\text { bonate } \\
\left(\mathrm{HCO}_{3}\right)\end{array}$ & $\begin{array}{c}\text { Car- } \\
\text { bonate } \\
\left(\mathrm{CO}_{3}\right)\end{array}$ & $\begin{array}{l}\text { Alka- } \\
\text { linity, } \\
\text { total as } \\
\left(\mathrm{CaCO}_{3}\right)\end{array}$ & $\begin{array}{c}\text { Sulfate, } \\
\text { dissolved } \\
\left(\mathrm{SO}_{4}\right)\end{array}$ & $\begin{array}{c}\text { Chloride, } \\
\text { dissolved } \\
\text { (CI) }\end{array}$ & $\begin{array}{c}\text { Fluoride, } \\
\text { dissolved } \\
\text { (F) }\end{array}$ & $\begin{array}{c}\text { Silica, } \\
\text { dissolved } \\
\left(\mathrm{SiO}_{2}\right) \\
\end{array}$ & $\begin{array}{l}\text { Dissolved } \\
\text { solids, } \\
\text { sum of } \\
\text { con- } \\
\text { stituents }\end{array}$ & $\begin{array}{c}\text { Nitrogen, } \\
\mathrm{NO}_{2}+\mathrm{NO}_{3} \text {, } \\
\text { dissolved } \\
\text { (as } \mathrm{N} \text { ) }\end{array}$ & $\begin{array}{c}\text { Phos- } \\
\text { phorus, } \\
\text { total } \\
\text { (P) }\end{array}$ \\
\hline \multicolumn{12}{|c|}{ and Colluvium--Continued } \\
\hline -- & -- & -- & -- & -- & -- & -- & -- & -- & -- & -- & -- \\
\hline 0.1 & 0.8 & -- & -- & 207 & 50 & 2.0 & 0.20 & 11 & 305 & 3.80 & -. \\
\hline .1 & 1.0 & -- & -- & 190 & 39 & 4.3 & .10 & 10 & 273 & 2.20 & 0.010 \\
\hline 3 & .8 & -- & -- & 184 & 48 & 150 & .10 & 9.6 & 503 & .310 & $<.010$ \\
\hline 2 & 1.0 & - & -- & 214 & 40 & 95 & .10 & 9.7 & 433 & .360 & .020 \\
\hline-- & -- & -- & -- & -- & -- & - & -- & -- & -- & -- & -- \\
\hline-- & -- & -- & -- & -- & -- & -- & - & -- & -- & -. & -- \\
\hline-- & -- & -- & -- & -- & -- & -- & -- & -- & -- & -- & -- \\
\hline -- & -- & -- & -- & -- & -- & -- & -- & -- & -- & -- & -- \\
\hline -- & -- & -- & -- & -- & -- & -- & -- & -- & -- & -- & -- \\
\hline .1 & .8 & -- & -- & 255 & 33 & 1.0 & .20 & 8.8 & 303 & .470 & -- \\
\hline .5 & 1.0 & -- & -. & 210 & 48 & 20 & .30 & 13 & 321 & .430 & .020 \\
\hline .3 & 1.1 & -- & .. & 230 & 48 & 8.9 & .10 & 12 & 312 & .710 & .030 \\
\hline .3 & 17 & -- & -- & 238 & 45 & 13 & .20 & 11 & 333 & .700 & -- \\
\hline-- & -- & -- & -- & -- & -- & -- & -- & -- & -- & -- & -- \\
\hline -- & -- & -- & -- & -- & -- & -- & -- & -- & -- & -- & -- \\
\hline-- & -- & -- & -- & $\cdots$ & $-\cdot$ & -- & - & -- & -- & -. & -- \\
\hline- & -- & -- & -- & -- & -- & -- & -- & -- & -- & -- & -- \\
\hline-- & -- & -- & -- & -- & -- & -- & -- & -- & -- & -- & -- \\
\hline -. & -- & -- & -- & -- & -- & -- & -- & -- & -- & -- & -- \\
\hline 0 & .5 & $-\cdot$ & -- & 191 & 30 & 1.1 & .20 & 6.1 & 239 & 1.80 & $<.010$ \\
\hline .4 & 5.6 & -- & -- & 291 & 37 & 20 & .40 & 23 & 417 & 1.90 & .080 \\
\hline -- & -- & -- & -- & -- & -- & -- & -- & -- & -- & -- & -- \\
\hline 0 & .5 & -- & -- & 195 & 30 & 1.1 & .30 & 6.1 & 243 & 1.50 & $<.010$ \\
\hline 0 & .9 & 252 & 0 & -- & 12 & 1.9 & .10 & 6.5 & 216 & .700 & -- \\
\hline .8 & 1.3 & -- & -- & 110 & 41 & $<1.0$ & .30 & 25 & 197 & 1.30 & -- \\
\hline .3 & 1.5 & -- & -- & 247 & 35 & 14 & .20 & 11 & 341 & 2.40 & .030 \\
\hline .4 & .8 & -- & -- & 200 & 38 & 15 & .20 & 8.3 & 282 & .670 & $<.010$ \\
\hline -- & -- & -- & -- & -- & -- & -- & -- & -- & -- & -- & -- \\
\hline .4 & .8 & -- & -- & 210 & 38 & 18 & .20 & 8.9 & 302 & -- & -- \\
\hline .4 & 1.0 & -- & -- & 215 & 39 & 16 & .10 & 9.2 & 301 & .750 & .020 \\
\hline .3 & 1.4 & -- & -- & 242 & 38 & 9.7 & .20 & 9.8 & 313 & .660 & -. \\
\hline
\end{tabular}


Table 14. Physical properties and chemical analyses of water samples collected from

\begin{tabular}{|c|c|c|c|c|c|c|c|c|c|c|}
\hline Station number & $\begin{array}{c}\text { Local number } \\
\text { (pl. 3) }\end{array}$ & $\begin{array}{c}\begin{array}{c}\text { Date } \\
\text { sampled }\end{array} \\
\end{array}$ & $\begin{array}{c}\text { Well } \\
\text { depth } \\
\text { (ft) }\end{array}$ & $\begin{array}{c}\text { Specific } \\
\text { conduc- } \\
\text { tance } \\
(\mu \mathrm{S} / \mathrm{cm})\end{array}$ & $\begin{array}{c}\text { pH } \\
\text { (stan- } \\
\text { dard } \\
\text { units) } \\
\end{array}$ & $\begin{array}{c}\text { Water } \\
\text { temper- } \\
\text { ature } \\
\left({ }^{\circ} \mathrm{C}\right) \\
\end{array}$ & $\begin{array}{c}\text { Hard- } \\
\text { ness } \\
\text { (as } \\
\left.\mathrm{CaCO}_{3}\right) \\
\end{array}$ & $\begin{array}{l}\text { Calcium, } \\
\text { dissolved } \\
\text { (Ca) }\end{array}$ & $\begin{array}{l}\text { Magne- } \\
\text { sium, } \\
\text { dissolved } \\
(\mathrm{Mg})\end{array}$ & $\begin{array}{c}\text { Sodium, } \\
\text { dissolved } \\
(\mathrm{Na})\end{array}$ \\
\hline & & & & & & & & & \multicolumn{2}{|c|}{ Quaternary Alluvium } \\
\hline \multirow[t]{2}{*}{430046111004301} & 35-119-15ddd01 & $07-27-92$ & 30 & 598 & 7.5 & 10.5 & -- & -- & -- & -- \\
\hline & & $10-05-93$ & 30 & 582 & 7.6 & 8.5 & 290 & 84 & 20 & 5.5 \\
\hline $430057111003801^{1}$ & $35-119-14 \mathrm{cbc01}$ & $11-20-93$ & 75 & 544 & 7.9 & 7.0 & 270 & 70 & 23 & 6.0 \\
\hline $430331111013301^{1}$ & $36-119-34 \mathrm{cbd} 01$ & $10-07-93$ & 85 & 379 & 7.8 & 8.0 & 190 & 48 & 18 & 3.0 \\
\hline 430356111013000 & 36-119-34bac00 & $09-10-71$ & 60 & 535 & 7.6 & 7.0 & 270 & 77 & 20 & 8.6 \\
\hline 430441111003601 & $36-119-26 b c c 01$ & $10-16-94$ & 140 & 472 & 7.6 & 8.0 & 240 & 65 & 20 & 2.0 \\
\hline \multirow[t]{2}{*}{430444111003701} & $36-119-26 b c b 01$ & $08-05-94$ & 110 & 466 & 7.6 & 8.0 & 250 & 62 & 22 & 2.4 \\
\hline & & $10-16-94$ & 110 & 467 & 7.6 & 8.0 & 240 & 62 & 21 & 2.2 \\
\hline 430527111011601 & 36-119-22саa01 & $07-26-92$ & 110 & 839 & 7.3 & 9.5 & -- & -- & -- & -- \\
\hline 430621111012100 & 36-119-15bdd00 & $09-08-71$ & 210 & 432 & 7.2 & 9.0 & 130 & 42 & 6.6 & 42 \\
\hline 430626111014501 & $36-119-15 b c c 01$ & $10-04-93$ & 50 & 582 & 7.6 & 10.0 & 260 & 72 & 20 & 6.5 \\
\hline 430924111021001 & 37-118-31baa01 & $09-12-93$ & 160 & 601 & 7.7 & 8.5 & 120 & 34 & 7.9 & 82 \\
\hline 430951111010800 & $37-118-29 \mathrm{cab} 01$ & $09-08-71$ & 300 & 602 & 7.5 & 18.0 & 310 & 86 & 24 & 5.5 \\
\hline 431030111020300 & $37-118-19 \mathrm{dcb} 00$ & 09-08-71 & 110 & 426 & 7.6 & 8.5 & 220 & 62 & 17 & 2.1 \\
\hline \multirow[t]{2}{*}{431041111011801} & $37-118-20 \mathrm{cba} 01$ & $09-12-93$ & 100 & 459 & 7.9 & -- & 240 & 58 & 22 & 3.0 \\
\hline & & & & & & & & & \multicolumn{2}{|c|}{ Quaternary } \\
\hline 424913110441901 & 33-116-30bbb01 & $09-10-93$ & Spring & 384 & 7.5 & 5.0 & 200 & 71 & 5.0 & 2.5 \\
\hline \multirow[t]{2}{*}{424919110444401} & NE & $09-10-93$ & Spring & 319 & 8.0 & 5.0 & -- & -- & -- & -- \\
\hline & & & & & & & & & \multicolumn{2}{|c|}{ Quaternary } \\
\hline \multirow[t]{2}{*}{415620110462800} & $23-118-26 \mathrm{ddb} 01$ & $06-24-75$ & Spring & 350 & 8.0 & 5.0 & 190 & 59 & 11 & 1.6 \\
\hline & & $05-20-94$ & Spring & 388 & 7.8 & 4.0 & 200 & 63 & 11 & 1.4 \\
\hline 422402110462501 & $28-117-19 b c c 01$ & $09-13-94$ & Spring & 325 & 8.0 & 11.5 & 160 & 45 & 12 & 1.4 \\
\hline 423319110395201 & NE & $08-02-94$ & Spring & 250 & 8.2 & 5.5 & 120 & 36 & 6.9 & 2.1 \\
\hline & & & & & & & & & \multicolumn{2}{|c|}{ Quaternary } \\
\hline 414749110410101 & $21-117-15 \mathrm{cad} 01$ & $06-23-95$ & 55 & 1,590 & 7.6 & 8.0 & 380 & 70 & 49 & 200 \\
\hline 414750110323001 & 21-116-14aaa01 & $05-26-58$ & Spring & 772 & 7.4 & 8.5 & 360 & 95 & 31 & 36 \\
\hline 414957110321501 & $21-116-01 b b 01$ & $11-07-72$ & 21 & 579 & 8.0 & 9.0 & 280 & 79 & 19 & 18 \\
\hline \multirow[t]{2}{*}{415218110294501} & $22-115-20 \mathrm{cba} 01$ & $11-08-72$ & Spring & 420 & -- & 6.0 & -- & -- & -- & -- \\
\hline & & $06-15-94$ & Spring & 463 & 7.7 & 9.0 & -- & -- & -- & -- \\
\hline 415450110574501 & $22-119-05 \mathrm{ccc} 01$ & $04-16-56$ & 28 & 864 & 7.7 & 3.5 & 344 & 84 & 32 & 51 \\
\hline 415555110572001 & 23-119-32bda01 & $04-16-56$ & 35.40 & 516 & 7.5 & 11.0 & 260 & 62 & 26 & 9.6 \\
\hline 420106110555401 & $24-119-33 \mathrm{ac} 01$ & $04-16-56$ & 22 & 855 & 7.7 & 5.5 & 330 & 60 & 43 & 72 \\
\hline 420526110530801 & $\mathrm{NE}$ & 06-11-95 & Spring & 606 & 7.7 & 7.5 & 300 & 84 & 22 & 8.2 \\
\hline 421145111014801 & $26-119-31 \mathrm{cb} 01$ & $09-21-71$ & 59 & 576 & 7.5 & 8.5 & 310 & 81 & 26 & 8.1 \\
\hline 423214110525101 & $30-118-33 \mathrm{dbd} 01$ & $08-03-94$ & Spring & 410 & 7.6 & 6.5 & 210 & 60 & 15 & 3.8 \\
\hline
\end{tabular}


wells completed in and springs issuing from selected geologic units in Lincoln County, Wyoming--Continued

\begin{tabular}{|c|c|c|c|c|c|c|c|c|c|c|c|}
\hline $\begin{array}{c}\text { Sodium } \\
\text { adsorp- } \\
\text { tion } \\
\text { ratio } \\
\end{array}$ & $\begin{array}{l}\text { Potas- } \\
\text { sium, } \\
\text { dissolved } \\
(\mathbf{K})\end{array}$ & $\begin{array}{r}\text { Bicar- } \\
\text { bonate } \\
\left(\mathrm{HCO}_{3}\right)\end{array}$ & $\begin{array}{c}\text { Car- } \\
\text { bonate } \\
\left(\mathrm{CO}_{3}\right)\end{array}$ & $\begin{array}{l}\text { Alka- } \\
\text { linity, } \\
\text { total as } \\
\left(\mathrm{CaCO}_{3}\right)\end{array}$ & $\begin{array}{l}\text { Sulfate, } \\
\text { dissolved } \\
\left(\mathrm{SO}_{4}\right)\end{array}$ & $\begin{array}{c}\text { Chloride, } \\
\text { dissolved } \\
\text { (CI) }\end{array}$ & $\begin{array}{c}\text { Fluoride, } \\
\text { dissolved } \\
(\mathrm{F})\end{array}$ & $\begin{array}{c}\text { Silica, } \\
\text { dissolved } \\
\left(\mathrm{SiO}_{2}\right)\end{array}$ & $\begin{array}{l}\text { Dissolved } \\
\text { solids, } \\
\text { sum of } \\
\text { con- } \\
\text { stituents } \\
\end{array}$ & $\begin{array}{c}\text { Nitrogen, } \\
\mathrm{NO}_{2}+\mathrm{NO}_{3}, \\
\text { dissolved } \\
\text { (as } \mathrm{N} \text { ) }\end{array}$ & $\begin{array}{c}\text { Phos- } \\
\text { phorus, } \\
\text { total } \\
(P)\end{array}$ \\
\hline \multicolumn{12}{|c|}{ and Colluvium--Continued } \\
\hline-- & -- & -- & -- & -- & -- & -- & -- & -- & -- & -- & -- \\
\hline 0.1 & 0.7 & -- & -- & 242 & 27 & 9.5 & 0.20 & 7.9 & 337 & 7.20 & $<0.010$ \\
\hline .2 & .9 & -- & -- & 245 & 27 & 8.4 & $<.10$ & 9.3 & 305 & 3.10 & .020 \\
\hline .1 & .6 & -- & -- & 171 & 17 & 4.0 & .10 & 5.8 & 214 & 2.60 & .020 \\
\hline .2 & .9 & -- & -- & 240 & 33 & 6.9 & .10 & 8.2 & 316 & 3.80 & -- \\
\hline .1 & .6 & -- & -- & 217 & 17 & .7 & $<.10$ & 8.5 & 271 & 5.30 & $<.010$ \\
\hline .1 & .5 & - & -- & 205 & 16 & 1.5 & .10 & 9.1 & 306 & 14.0 & $<.010$ \\
\hline .1 & .7 & -- & -- & 210 & 16 & 1.3 & $<.10$ & 8.8 & 256 & 5.90 & $<.010$ \\
\hline -- & -- & -- & -- & -- & -- & -- & -- & -- & $\therefore-$ & -- & -. \\
\hline 2 & 4.3 & -- & -- & 218 & 2.8 & 1 & .30 & 15 & 272 & 3.80 & -- \\
\hline .2 & .9 & -- & -- & 240 & 26 & 7.6 & .20 & 7.6 & 303 & 4.10 & $<.010$ \\
\hline 3 & 7.3 & -- & -- & 283 & 32 & 4.3 & 1.9 & 47 & 388 & $<.050$ & .010 \\
\hline .1 & 1.1 & -- & -- & 307 & 8.8 & 0 & .20 & 11 & 351 & 4.60 & -- \\
\hline .1 & .7 & -- & -- & 220 & 9.5 & 1.5 & .20 & 12 & 242 & 1.10 & -- \\
\hline .1 & .7 & -- & -- & 244 & 9.8 & 2.1 & .20 & 12 & 257 & .640 & $<.010$ \\
\hline
\end{tabular}

Glacial Deposits

$\begin{array}{llllll}.1 & .6 & -- & -- & 207\end{array}$

2.7

Landslide Deposits

$\begin{array}{lllllcrrrr}0 & .7 & -- & -- & 189 & 1.6 & 3.6 & .10 & 5.7 & 197 \\ 0 & .4 & -- & -- & 211 & 3.4 & .9 & .20 & 6.3 & 214 \\ 0 & .5 & -- & -- & 104 & 60 & .5 & .10 & 5.4 & 190 \\ .1 & .3 & -- & -- & 67 & 54 & .5 & .20 & 9.0 & 150\end{array}$

Terrace Deposits

\begin{tabular}{|c|c|c|c|c|c|c|c|c|c|c|c|}
\hline 4 & 2.6 & -- & -- & 300 & 400 & 83 & .90 & 11 & 1,010 & .080 & .030 \\
\hline .8 & -- & 327 & 0 & -- & 130 & 22 & -- & 17 & 501 & -- & -- \\
\hline .5 & 2.8 & -- & -- & 252 & 43 & 14 & .30 & 14 & 347 & -- & -- \\
\hline-- & -- & -- & -- & -- & -- & -- & -- & -- & -- & -- & -- \\
\hline -- & -- & -- & -- & -. & -- & -- & -- & -- & -- & -- & -. \\
\hline 1.2 & -- & 292 & 0 & -- & 100 & 69 & -. & -. & 510 & -- & -. \\
\hline 0.3 & -- & 246 & 0 & -- & 64 & 10 & -- & -- & 297 & -- & -- \\
\hline 2 & - & 379 & 0 & -- & 130 & 25 & -- & -- & 521 & -- & -- \\
\hline .2 & 0.8 & -- & -- & 216 & 100 & 5.7 & 0.30 & 18 & 363 & -- & .. \\
\hline .2 & 1.8 & 320 & 0 & -- & 52 & 7.3 & .20 & 17 & 351 & -- & -- \\
\hline .1 & .7 & -- & -- & 216 & 9.1 & 1.2 & .20 & 11 & 231 & -. & -- \\
\hline
\end{tabular}


Table 14. Physical properties and chemical analyses of water samples collected from

\begin{tabular}{|c|c|c|c|c|c|c|c|c|c|c|}
\hline Station number & $\begin{array}{c}\text { Local number } \\
\text { (pl. 3) }\end{array}$ & $\begin{array}{c}\text { Date } \\
\text { sampled }\end{array}$ & $\begin{array}{c}\text { Well } \\
\text { depth } \\
\text { (ft) }\end{array}$ & $\begin{array}{c}\text { Specific } \\
\text { conduc- } \\
\text { tance } \\
(\mu \mathrm{S} / \mathrm{cm}) \\
\end{array}$ & $\begin{array}{l}\text { pH } \\
\text { (stan- } \\
\text { dard } \\
\text { units) }\end{array}$ & $\begin{array}{c}\text { Water } \\
\text { temper- } \\
\text { ature } \\
\left({ }^{\circ} \mathrm{C}\right) \\
\end{array}$ & $\begin{array}{c}\text { Hard- } \\
\text { ness } \\
\text { (as } \\
\mathrm{CaCO}_{3} \text { ) } \\
\end{array}$ & $\begin{array}{l}\text { Calcium, } \\
\text { dissolved } \\
\text { (Ca) }\end{array}$ & $\begin{array}{l}\text { Magne- } \\
\text { sium, } \\
\text { dissolved } \\
(\mathrm{Mg})\end{array}$ & $\begin{array}{c}\text { Sodium, } \\
\text { dissolvec } \\
(\mathrm{Na})\end{array}$ \\
\hline & & & & & & & & & \multicolumn{2}{|c|}{ Undifferentiated } \\
\hline \multirow[t]{2}{*}{414007110172501} & $20-114-33 d d b 01$ & $07-31-95$ & 881 & 3,590 & 8.7 & 14.5 & 8 & 1.4 & 1.0 & 860 \\
\hline & & $07-31-95$ & 881 & 3,590 & 8.7 & 14.5 & 7 & 1.3 & 1.0 & 860 \\
\hline 415210110303501 & $22-115-1901$ & $05-26-58$ & Spring & 542 & 7.9 & 14.5 & 9 & 2.8 & .5 & 130 \\
\hline \multirow[t]{2}{*}{415730110160301} & $23-113-20 c b d 01$ & $06-13-94$ & 900 & 1,240 & 9.6 & 12.0 & 3 & .6 & .25 & 280 \\
\hline & & & & & & & & & \multicolumn{2}{|c|}{ Salt Lake and } \\
\hline 423958110591600 & $31-119-15 \operatorname{cc} 00$ & $09-14-71$ & 70 & 506 & 7.4 & 7.0 & 240 & 72 & 15 & 14 \\
\hline 424828110533601 & 33-118-34aaa01 & $09-15-94$ & Spring & 290 & 7.5 & 9.0 & -- & -- & -- & -- \\
\hline 425430110582001 & $34-119-24 \mathrm{ddc} 01$ & $09-10-71$ & Spring & 394 & 8.0 & 8.0 & 210 & 53 & 18 & 1.0 \\
\hline 430544110595800 & $36-119-23 a b c 00$ & $09-10-71$ & 126 & 450 & 7.5 & 9.0 & 250 & 64 & 21 & 2.7 \\
\hline 430550111011401 & 36-119-22abb01 & $07-25-92$ & 220 & 525 & 7.6 & 7.5 & -- & -- & -- & -- \\
\hline 430921111003800 & 37-118-33bab00 & $09-08-71$ & Spring & 494 & 7.4 & 8.0 & 270 & 75 & 21 & 2.9 \\
\hline 430519111005801 & $36-119-22 \mathrm{dbd} 01$ & 08-06-94 & 309 & 582 & 7.6 & 9.0 & 300 & 80 & 25 & 8.1 \\
\hline 430528111010201 & $36-119-22 \mathrm{dba0} 1$ & 08-06-94 & 105 & 607 & 7.6 & 8.0 & 320 & 84 & 26 & 8.0 \\
\hline 430543111010301 & 36-119-22abd01 & $07-26-92$ & -- & 664 & 7.2 & 9.5 & -- & -- & -- & -- \\
\hline \multirow[t]{2}{*}{431224111014001} & $\mathrm{NE}$ & 08-10-93 & Spring & 383 & 7.6 & 7.0 & 210 & 51 & 19 & 0.9 \\
\hline & & & & & & & & & & Bridger \\
\hline 414546110195401 & 21-114-34aba01 & $06-25-95$ & 142 & 1,570 & 7.6 & 8.0 & 420 & 120 & 30 & 190 \\
\hline \multirow[t]{2}{*}{414555110232701} & 21-114-30dcd01 & 06-26-95 & 65 & 1,310 & 7.5 & 18.0 & 400 & 73 & 52 & 130 \\
\hline & & & & & & & & & & Fowkes \\
\hline 413625111023001 & 19-121-25aad01 & $07-07-72$ & Spring & 696 & 8.2 & 11.0 & 240 & 58 & 24 & 58 \\
\hline 414343110560701 & 20-120-12cad01 & $06-20-95$ & Spring & 605 & 7.9 & 13.0 & 280 & 73 & 24 & 17 \\
\hline \multirow[t]{2}{*}{420310110535701} & 24-119-23bab01 & $05-31-94$ & Spring & 525 & 7.8 & 7.0 & -- & -- & -- & -- \\
\hline & & & & & & & & & \multicolumn{2}{|c|}{ Laney Member of } \\
\hline \multirow[t]{2}{*}{414517110240701} & $21-114-31 \mathrm{cbb} 01$ & 06-26-95 & 155 & 1,050 & 9.5 & 8.5 & 7 & 1.2 & 1.0 & 200 \\
\hline & & 06-26-95 & 155 & 1,050 & 9.5 & 8.5 & 7 & 1.2 & 1.0 & 200 \\
\hline 414625110192001 & $21-114-26 b c c 01$ & $06-23-65$ & 180 & 2,350 & 8.1 & 12.0 & 14 & 5.0 & .4 & 550 \\
\hline 414708110140001 & 21-113-21 adc01 & $06-25-95$ & 55 & 5,540 & 7.4 & 10.0 & 1,600 & 330 & 180 & 860 \\
\hline \multirow[t]{2}{*}{415210110082201} & $22-112-20 \mathrm{dac} 01$ & $10-19-65$ & 616 & 1,990 & 9.4 & 11.0 & 0 & ND & ND & 500 \\
\hline & & $05-22-94$ & 616 & 1,990 & 9.6 & 11.5 & 1 & .4 & .1 & 480 \\
\hline \multirow[t]{2}{*}{415445110111501} & $22-113-01 \mathrm{cdb} 01$ & $09-12-64$ & -- & 1,450 & 9.5 & 13.0 & 2 & 0.9 & ND & 360 \\
\hline & & $05-21-94$ & -- & 1,440 & 9.6 & 12.0 & 2 & .5 & 0.17 & 330 \\
\hline 415858110111201 & $23-113-12 \mathrm{ccd} 01$ & $10-17-77$ & Spring & 1,300 & 7.8 & 7.5 & 370 & 68 & 48 & 160 \\
\hline \multirow[t]{2}{*}{420430110191901} & $24-112-08 \mathrm{cbb} 01$ & $06-28-66$ & 150 & 971 & 8.2 & 11.0 & 310 & 58 & 40 & 110 \\
\hline & & & & & & & & \multicolumn{3}{|c|}{ Wilkins Peak Member of } \\
\hline 414311110253401 & 20-115-17ada01 & $11-06-76$ & Spring & 5,000 & 9.9 & 6.0 & 27 & 1.3 & 5.7 & 1,100 \\
\hline
\end{tabular}


wells completed in and springs issuing from selected geologic units in Lincoln County, Wyoming--Continued

\begin{tabular}{|c|c|c|c|c|c|c|c|c|c|}
\hline $\begin{array}{l}\text { Sodium } \\
\text { adsorp- } \\
\text { tion } \\
\text { ratio }\end{array}$ & $\begin{array}{c}\text { Potas- } \\
\text { sium, } \\
\text { dissolved } \\
(\mathrm{K}) \\
\end{array}$ & $\begin{array}{r}\text { Bicar- } \\
\text { bonate } \\
\left(\mathrm{HCO}_{3}\right)\end{array}$ & $\begin{array}{c}\text { Car- } \\
\text { bonate } \\
\left(\mathrm{CO}_{3}\right)\end{array}$ & $\begin{array}{c}\text { Alka- } \\
\text { linity, } \\
\text { total as } \\
\left(\mathrm{CaCO}_{3}\right)\end{array}$ & $\begin{array}{r}\text { Sulfate, } \\
\text { dissolved } \\
\left(\mathrm{SO}_{4}\right)\end{array}$ & $\begin{array}{l}\text { Chloride, } \\
\text { dissolved } \\
\text { (CI) }\end{array}$ & $\begin{array}{c}\text { Fluoride, } \\
\text { dissolved } \\
\text { (F) }\end{array}$ & $\begin{array}{c}\begin{array}{c}\text { Silica, } \\
\text { dissolved } \\
\left(\mathrm{SiO}_{2}\right)\end{array} \\
\end{array}$ & $\begin{array}{r}\text { Disso } \\
\text { soli } \\
\text { sum } \\
\text { con } \\
\text { stitue }\end{array}$ \\
\hline \multicolumn{10}{|c|}{ Tertiary Rocks } \\
\hline 140 & 1.4 & -- & -- & 1,080 & 280 & 330 & 2.8 & 8.2 & \\
\hline 140 & 1.3 & -- & -- & 1,080 & 290 & 340 & 3.3 & 8.2 & 2,1 \\
\hline 19 & -- & 320 & -- & -- & 27 & 6.0 & -- & 9.1 & \\
\hline 75 & .5 & -- & -- & 430 & 170 & 19 & 1.2 & 9.7 & \\
\hline
\end{tabular}

\section{Teewinot Formations}

\begin{tabular}{|c|c|c|c|c|c|c|c|c|c|c|c|}
\hline .4 & 1.2 & -- & -- & 255 & 50 & 6.7 & .20 & 20 & 315 & 0.200 & -- \\
\hline -- & -- & - & -- & -- & -- & -- & -- & -- & -- & -- & -- \\
\hline 0 & .7 & 207 & 0 & -- & 30 & 2.1 & .30 & 10 & 236 & -- & -- \\
\hline .1 & .8 & -- & -- & 259 & 4.3 & 2.7 & .10 & 9.9 & 263 & .480 & -- \\
\hline -- & -- & -- & -- & -- & -- & - & -- & -- & -- & -- & -- \\
\hline .1 & .8 & -- & -- & 285 & 0.3 & 2.4 & .20 & 12 & 287 & .200 & -- \\
\hline .2 & .9 & -- & -- & 323 & 9.1 & 4.2 & .20 & 19 & 337 & $<.050$ & 0.020 \\
\hline .2 & .9 & -- & -- & 309 & 22 & 4.1 & .20 & 14 & 349 & $<.050$ & $<.010$ \\
\hline -- & -. & -- & -- & -- & -- & -- & -- & -- & -- & -- & -- \\
\hline 0 & .5 & -- & -- & 213 & 2.3 & 0.7 & $<.10$ & 5.3 & 206 & -. & -- \\
\hline
\end{tabular}

Formation

$\begin{array}{rrrrrrrrrrrr}4 & .5 & -- & -- & 364 & 420 & 48 & .60 & 12 & 1,050 & <.050 & .010 \\ 3 & 1.6 & -- & -- & 323 & 350 & 29 & .20 & 25 & 859 & <.050 & <.010\end{array}$

Formation

$\begin{array}{rrrrrrrrrr}1.6 & 5.1 & 313 & 0 & -- & 52 & 42 & .40 & 41 & 438 \\ .4 & 1.6 & -- & -- & 243 & 51 & 23 & .40 & 10 & 346\end{array}$

the Green River Formation

\begin{tabular}{|c|c|c|c|c|c|c|c|c|c|c|c|}
\hline 33 & .5 & -- & -- & 329 & 120 & 17 & .90 & 12 & 551 & .330 & .020 \\
\hline 33 & .5 & -- & -- & 360 & 120 & 17 & 1.0 & 12 & 570 & .330 & .020 \\
\hline 63 & 1.0 & -- & -- & 272 & 750 & 82 & 1.9 & 7.4 & 1,560 & $-\cdots$ & -- \\
\hline 9 & 4.2 & -- & -- & 380 & 2,600 & 250 & .30 & 10 & 4,480 & .210 & .010 \\
\hline 0 & 1.0 & - & -- & 886 & 140 & 29 & 5.3 & 11 & 1,220 & -- & -- \\
\hline 180 & .9 & 698 & 204 & 912 & 130 & 29 & 4.4 & 10 & 1,200 & -- & -- \\
\hline 100 & 0.6 & 514 & 136 & -- & 100 & 18 & 1.9 & -- & 875 & -- & -- \\
\hline 110 & .9 & 476 & 156 & 650 & 110 & 16 & 1.6 & 11 & 860 & -- & -- \\
\hline 4 & 1.2 & -- & -- & 290 & 400 & 18 & 0.40 & 22 & 890 & $<0.100$ & 0.010 \\
\hline 3 & 2.0 & 334 & 0 & -- & 230 & 22 & .50 & 18 & 650 & -- & -- \\
\hline \multicolumn{12}{|c|}{ the Green River Formation } \\
\hline 93 & 2.2 & -- & -- & 1,890 & 200 & 310 & 7.1 & 10 & 2,780 & .080 & .240 \\
\hline
\end{tabular}


Table 14. Physical properties and chemical analyses of water samples collected from

\begin{tabular}{|c|c|c|c|c|c|c|c|c|c|c|}
\hline Station number & $\begin{array}{l}\text { Local number } \\
\text { (pl. 3) }\end{array}$ & $\begin{array}{c}\text { Date } \\
\text { sampled }\end{array}$ & $\begin{array}{c}\text { Well } \\
\text { depth } \\
\text { (ft) }\end{array}$ & $\begin{array}{c}\text { Specific } \\
\text { conduc- } \\
\text { tance } \\
(\mu \mathrm{S} / \mathrm{cm}) \\
\end{array}$ & $\begin{array}{l}\text { pH } \\
\text { (stan- } \\
\text { dard } \\
\text { units) }\end{array}$ & $\begin{array}{c}\text { Water } \\
\text { temper- } \\
\text { ature } \\
\left({ }^{\circ} \mathrm{C}\right) \\
\end{array}$ & $\begin{array}{c}\text { Hard- } \\
\text { ness } \\
\text { (as } \\
\left.\mathrm{CaCO}_{3}\right) \\
\end{array}$ & $\begin{array}{l}\text { Calcium, } \\
\text { dissolved } \\
\text { (Ca) }\end{array}$ & $\begin{array}{c}\text { Magne- } \\
\text { sium, } \\
\text { dissolved } \\
(\mathrm{Mg})\end{array}$ & $\begin{array}{c}\text { Sodium, } \\
\text { dissolved } \\
\text { (Na) }\end{array}$ \\
\hline & & & & & & & & & \multicolumn{2}{|c|}{ Angelo Member of } \\
\hline \multirow[t]{3}{*}{415511110414101} & $22-117-04 a b c 01$ & $10-20-77$ & Spring & 400 & 7.4 & 6.5 & 210 & 46 & 23 & 11 \\
\hline & & $07-11-95$ & Spring & 450 & 7.6 & 7.5 & -- & -- & -. & -- \\
\hline & & & & & & & & \multicolumn{3}{|c|}{ Fossil Butte Member of } \\
\hline 413654110470701 & 19-118-20cba0l & $06-23-95$ & Spring & 755 & 7.5 & 6.0 & -- & -- & -- & -- \\
\hline \multirow[t]{2}{*}{413715110470701} & 19-118-20bba0l & $11-06-76$ & Spring & 720 & 7.3 & 6.5 & 380 & 77 & 45 & 22 \\
\hline & & $06-23-95$ & Spring & 833 & 7.4 & 6.0 & 400 & 84 & 45 & 26 \\
\hline 413941110402201 & $19-117-05 \mathrm{bcb} 01$ & $06-12-95$ & Spring & 675 & 7.6 & 6.0 & 320 & 57 & 44 & 17 \\
\hline 414254110505001 & 20-119-15dad01 & $05-22-95$ & Spring & 1,060 & 7.5 & 5.0 & 530 & 110 & 63 & 25 \\
\hline 414358110420501 & $20-118-12 \mathrm{acc} 0 \mathrm{l}$ & $06-13-95$ & Spring & 980 & 7.5 & 7.0 & -- & -- & -- & -- \\
\hline 414458110495301 & $21-118-32 d d c 01$ & $06-21-95$ & Spring & 1,150 & 7.4 & 7.0 & 630 & 140 & 67 & 18 \\
\hline 414539110415601 & 21-117-33abd01 & 06-13-95 & Spring & 990 & 7.6 & 7.0 & 430 & 100 & 44 & 40 \\
\hline 414617110440901 & 21-117-30adc01 & $06-13-95$ & Spring & 1,210 & 7.4 & 7.0 & 570 & 130 & 60 & 45 \\
\hline 414717110433001 & 21-117-20bdb01 & 06-13-95 & Spring & 1,120 & 7.7 & 10.0 & 460 & 100 & 52 & 53 \\
\hline 415212110462201 & $22-118-23 \mathrm{dac} 01$ & $06-16-93$ & Spring & 570 & 7.7 & 6.5 & 280 & 57 & 33 & 9.7 \\
\hline 415757110433301 & 23-117-19aaa01 & $07-11-95$ & Spring & 345 & 7.8 & 6.0 & 170 & 37 & 19 & 6.4 \\
\hline \multirow[t]{2}{*}{415758110433301} & $23-117-17 \mathrm{ccc} 01$ & $07-11-95$ & Spring & 310 & 8.0 & 6.5 & -- & -- & -- & -- \\
\hline & & & & & & & & & & Wasatch \\
\hline \multirow[t]{2}{*}{413502110531101} & 19-119-32dad01 & $06-13-72$ & Spring & 485 & 8.2 & 6.5 & 240 & 55 & 25 & 5.3 \\
\hline & & $06-22-95$ & Spring & 656 & 7.5 & 6.5 & 310 & 70 & 33 & 14 \\
\hline \multirow[t]{2}{*}{413658110421701} & $19-118-24 \mathrm{caa} 01$ & $11-06-76$ & 200 & 1,500 & 7.7 & -- & 17 & 52 & 10 & 300 \\
\hline & & $07-19-83$ & 200 & -- & -- & -- & 12 & 35 & 7.7 & 330 \\
\hline \multirow[t]{3}{*}{413803110531701} & 19-119-17aаa01 & $06-07-72$ & Spring & 530 & -- & 7.0 & -- & -- & -- & -- \\
\hline & & $11-06-76$ & Spring & 590 & 7.9 & 7.0 & 290 & 60 & 35 & 7.9 \\
\hline & & $06-22-95$ & Spring & 579 & 7.5 & 7.0 & 290 & 63 & 33 & 10 \\
\hline 413806110524601 & $19-119-16 \mathrm{bac} 01$ & $06-22-95$ & Spring & 850 & 7.4 & 8.0 & -- &.- & -- & -- \\
\hline 413825110513101 & $19-119-10 \mathrm{cda} 01$ & $06-22-95$ & Spring & 855 & 7.5 & 6.5 & -- & -- & -- & -- \\
\hline \multirow[t]{2}{*}{414055110293601} & $20-116-26 \mathrm{cdd} 01$ & $11-06-76$ & Spring & 970 & 8.0 & 8.0 & 210 & 41 & 26 & 130 \\
\hline & & $07-30-95$ & Spring & 1,050 & 7.1 & 10.5 & -- & -- & -- & -- \\
\hline 414312110480501 & $20-118-18 \mathrm{bac} 01$ & $06-12-95$ & Spring & 650 & 7.4 & 6.0 & 320 & 81 & 29 & 4.7 \\
\hline 414707110485901 & $21-118-21 \mathrm{acc} 01$ & $06-21-95$ & Spring & 777 & 7.6 & 7.0 & 350 & 81 & 37 & 26 \\
\hline 414708110533901 & $21-119-23 \mathrm{acc} 01$ & $06-24-95$ & Spring & 652 & 7.5 & 10.0 & 300 & 92 & 16 & 20 \\
\hline 414800110442001 & $21-117-18 \mathrm{ac} 01$ & $09-22-71$ & Spring & 1,740 & 7.5 & 6.0 & 900 & 200 & 97 & 90 \\
\hline
\end{tabular}


wells completed in and springs issuing from selected geologic units in Lincoln County, Wyoming--Continued

\begin{tabular}{|c|c|c|c|c|c|c|c|c|c|c|c|}
\hline $\begin{array}{l}\text { Sodium } \\
\text { adsorp- } \\
\text { tion } \\
\text { ratio } \\
\end{array}$ & $\begin{array}{c}\text { Potas- } \\
\text { sium, } \\
\text { dissolved } \\
(\mathrm{K})\end{array}$ & $\begin{array}{c}\text { Bicar- } \\
\text { bonate } \\
\left(\mathrm{HCO}_{3}\right)\end{array}$ & $\begin{array}{c}\text { Car- } \\
\text { bonate } \\
\left(\mathrm{CO}_{3}\right) \\
\end{array}$ & $\begin{array}{c}\text { Alka- } \\
\text { linity, } \\
\text { total as } \\
\left(\mathrm{CaCO}_{3}\right)\end{array}$ & $\begin{array}{c}\text { Sulfate, } \\
\text { dissolved } \\
\left(\mathrm{SO}_{4}\right)\end{array}$ & $\begin{array}{c}\text { Chloride, } \\
\text { dissolved } \\
\text { (Cl) }\end{array}$ & $\begin{array}{c}\text { Fluoride, } \\
\text { dissolved } \\
\text { (F) }\end{array}$ & $\begin{array}{c}\text { Silica, } \\
\text { dissolved } \\
\left(\mathrm{SiO}_{2}\right)\end{array}$ & $\begin{array}{l}\text { Dissolved } \\
\text { solids, } \\
\text { sum of } \\
\text { con- } \\
\text { stituents } \\
\end{array}$ & $\begin{array}{c}\mathrm{Nitrogen}, \\
\mathrm{NO}_{2}+\mathrm{NO}_{3}, \\
\text { dissolved } \\
\text { (as } \mathrm{N} \text { ) }\end{array}$ & $\begin{array}{c}\text { Phos- } \\
\text { phorus, } \\
\text { total } \\
\text { (P) }\end{array}$ \\
\hline \multicolumn{12}{|c|}{ the Green River Formation } \\
\hline 0.3 & 2.4 & -- & -- & 210 & 15 & 5.0 & .40 & 14 & 243 & .820 & .020 \\
\hline-- & -- & -- & -- & - & -- & -- & -- & -- & -- & -- & -- \\
\hline \multicolumn{12}{|c|}{ the Green River Formation } \\
\hline-- & -- & -- & -- & -- & -- & -- & -- & -- & -- & -- & -- \\
\hline .5 & 2.4 & -- & -- & 332 & 83 & 18 & .40 & 7.5 & 455 & .090 & .010 \\
\hline .6 & 2.4 & -- & -- & 320 & 83 & 33 & .40 & 8.3 & 479 & -- & -- \\
\hline .4 & 2.6 & -- & - & 253 & 84 & 15 & .60 & 11 & 389 & -- & -- \\
\hline .5 & 2.4 & - & -- & 287 & 260 & 24 & .50 & 12 & 679 & -- & -- \\
\hline-- & -- & - & -- & -- & -- & -- & -- & -- & -- & -- & -- \\
\hline .3 & 2.8 & -- & -- & 326 & 300 & 20 & .30 & 12 & 764 & -- & -- \\
\hline .8 & 1.3 & -- & -- & 280 & 260 & 6.8 & .30 & 28 & 653 & -- & -- \\
\hline .8 & 2.1 & -- & -. & 268 & 400 & 17 & .30 & 20 & 836 & -- & -- \\
\hline 1 & .4 & -- & -- & 195 & 400 & 11 & .20 & 21 & 757 & -- & -- \\
\hline .3 & 1.7 & -- & -- & 202 & 87 & 12 & .30 & 11 & 351 & -- & -- \\
\hline .2 & .5 & -- & -- & 162 & 6.0 & 2.6 & .70 & 14 & 193 & -- & -- \\
\hline-- & -- & -- & -- & -- & -- & -- & -- & -- & -- & -- & -- \\
\hline \multicolumn{12}{|c|}{ Formation } \\
\hline .1 & 1.2 & 281 & 0 & -- & 12 & 6.7 & .30 & 7.9 & 263 & -- & -- \\
\hline .3 & 1.4 & -- & -- & 248 & 22 & 48 & .30 & 7.6 & 349 & -- & - \\
\hline 10 & 4.8 & -- & -- & 145 & 590 & 38 & 1.0 & 6.0 & 1,090 & .220 & .010 \\
\hline 13 & 3.6 & -- & -- & 180 & 600 & 50 & .80 & 6.9 & 1,140 & .300 & -- \\
\hline-- & -- & -- & -- & -- & -- & -- & -- & -- & -- & -- & -- \\
\hline .2 & 1.0 & -- & -- & 263 & 32 & 12 & .30 & 7.1 & 317 & .800 & .010 \\
\hline .3 & 1.0 & -- & -- & 262 & 27 & 12 & .40 & 7.8 & 319 & -- & -- \\
\hline -- & -- & -- & -- & -- & -- & -- & -- & -- & -- & -- & - \\
\hline-- & -- & -- & -- & -- & -- & -- & -- & -- & -- & -- & -- \\
\hline 4 & 2.2 & -- & -- & 249 & 190 & 48 & 0.80 & 9.8 & 597 & $<0.100$ & 0.010 \\
\hline -- & -- & - & -- & -- & -- & -- & -- & -- & -- & -- & -- \\
\hline 0.1 & 1.2 & -- & -- & 295 & 22 & 18 & .20 & 7.4 & 344 & -- & -- \\
\hline .6 & 2.6 & -- & -- & 271 & 80 & 44 & .40 & 13 & 450 & -- & -- \\
\hline .5 & 5.1 & -- & -- & 195 & 100 & 18 & .40 & 11 & 393 & -- & -- \\
\hline 1 & 1.4 & -- & -- & 273 & 790 & 16 & .30 & 26 & 1,380 & .040 & -- \\
\hline
\end{tabular}


Table 14. Physical properties and chemical analyses of water samples collected from

\begin{tabular}{|c|c|c|c|c|c|c|c|c|c|c|}
\hline Station number & $\begin{array}{l}\text { Local number } \\
\text { (pl. 3) }\end{array}$ & $\begin{array}{c}\text { Date } \\
\text { sampled }\end{array}$ & $\begin{array}{c}\text { Well } \\
\text { depth } \\
(\mathrm{ft})\end{array}$ & $\begin{array}{c}\text { Specific } \\
\text { conduc- } \\
\text { tance } \\
(\mu \mathrm{S} / \mathrm{cm})\end{array}$ & $\begin{array}{c}\text { pH } \\
\text { (stan- } \\
\text { dard } \\
\text { units) } \\
\end{array}$ & $\begin{array}{c}\text { Water } \\
\text { temper- } \\
\text { ature } \\
\left({ }^{\circ} \mathrm{C}\right)\end{array}$ & $\begin{array}{c}\text { Hard- } \\
\text { ness } \\
\text { (as } \\
\left.\mathrm{CaCO}_{3}\right) \\
\end{array}$ & $\begin{array}{c}\text { Calcium, } \\
\text { dissolved } \\
\text { (Ca) }\end{array}$ & $\begin{array}{l}\text { Magne- } \\
\text { sium, } \\
\text { dissolved } \\
(\mathrm{Mg}) \\
\end{array}$ & $\begin{array}{c}\text { Sodium, } \\
\text { dissolved } \\
(\mathrm{Na})\end{array}$ \\
\hline & & & & & & & & & & Wasatch \\
\hline 414925110473001 & $21-118-02 \mathrm{cc} 01$ & $10-18-71$ & 350 & 1,980 & 8.4 & 7.5 & 10 & 3.1 & 0.6 & 410 \\
\hline 414954110493701 & 21-118-04bcb01 & $06-16-93$ & Spring & 920 & -- & 8.5 & -- & -- & -- & -- \\
\hline 415038110451001 & $22-118-25 \mathrm{dda} 01$ & $10-20-77$ & 465 & 8,500 & 8.0 & 9.5 & 190 & 49 & 16 & 2,000 \\
\hline 415117110541301 & $22-119-26 \mathrm{cbc} 01$ & $06-21-95$ & Spring & 770 & 7.4 & 13.0 & -- & -- & -- & -- \\
\hline 415411110242301 & $22-115-12 \mathrm{adb} 01$ & $06-15-94$ & Spring & 940 & 7.7 & 6.5 & 430 & 94 & 48 & 41 \\
\hline 415640110195001 & $23-114-27 \mathrm{cbc} 01$ & $05-25-66$ & -- & 1,380 & 8.5 & 9.5 & 230 & 24 & 42 & 240 \\
\hline 415839110241901 & $23-115-13 \mathrm{bbd} 01$ & $06-14-94$ & Spring & 723 & 7.6 & 9.0 & 300 & 88 & 19 & 38 \\
\hline 415839110261901 & 23-115-15bad01 & $06-14-94$ & Spring & 801 & 7.6 & 6.0 & -- & -- & -- & -- \\
\hline 420611110392801 & $25-116-32 c c b 01$ & $08-01-95$ & Spring & 373 & 7.7 & 8.0 & 190 & 61 & 9.1 & 1.7 \\
\hline 420754110423701 & $25-117-23 \mathrm{cdc} 01$ & $08-01-95$ & Spring & 633 & 7.8 & 10.5 & -- & -- & -- & -- \\
\hline 420958110192701 & 25-114-12daa01 & $07-29-95$ & Spring & 583 & 7.7 & 8.0 & 230 & 59 & 20 & 37 \\
\hline 421258110100401 & $26-112-21 \mathrm{ccb} 01$ & $08-20-76$ & 300 & 2,600 & -- & 17.0 & 12 & 2.5 & 1.3 & 590 \\
\hline 421446110435701 & $26-117-16 \mathrm{bbd} 01$ & $07-11-95$ & Spring & 349 & 7.5 & 4.5 & 200 & 76 & 3.3 & 2.1 \\
\hline 421501110115001 & 26-112-07bcd01 & $08-20-76$ & 265 & 3,400 & -- & 12.0 & 410 & 67 & 60 & 450 \\
\hline 421504110195501 & $26-114-12 \mathrm{db} 01$ & $06-07-86$ & Spring & 470 & - & -- & 240 & 50 & 27 & 7.0 \\
\hline 421512110132601 & 26-113-11ac01 & $06-16-66$ & 145 & 1,010 & 8.2 & 8.0 & 490 & 86 & 68 & 43 \\
\hline 421540110114101 & 26-112-06acc01 & $08-20-76$ & 92 & 2,050 & -- & 18.0 & 570 & 46 & 110 & 290 \\
\hline 421545110452001 & $26-117-05 \mathrm{ccc} 01$ & $09-14-94$ & Spring & 377 & 7.7 & 5.0 & -- & -- & -- & -- \\
\hline 421551110120701 & 26-112-06bcd01 & $08-20-76$ & 55 & 2,200 & - & 21.0 & 730 & 79 & 130 & 250 \\
\hline 421554110112901 & 21-112-06acd01 & $08-20-76$ & 85 & 1,600 & -- & 12.0 & 150 & 17 & 27 & 300 \\
\hline \multirow[t]{2}{*}{425851110471201} & $23-118-11 \mathrm{ccd} 01$ & $05-20-94$ & Spring & 469 & 7.5 & 5.5 & 240 & 76 & 12 & 2.4 \\
\hline & & & & & & & & & & Evanston \\
\hline 414758110474701 & $21-118-15 \mathrm{dba} 01$ & $06-13-95$ & Spring & 997 & 7.4 & 8.5 & 410 & 88 & 47 & 48 \\
\hline 414811110405201 & 21-117-15acb01 & $06-23-95$ & 264 & 7,680 & 8.3 & 12.0 & 190 & 30 & 29 & 1,800 \\
\hline 415415110373001 & $22-116-0701$ & $05-26-58$ & Spring & 494 & 7.9 & - & 210 & 66 & 10 & 22 \\
\hline \multirow[t]{3}{*}{415515110373001} & $22-116-06 a b 01$ & $09-30-71$ & Spring & 1,280 & -- & 11.0 & -- & -- & -- & -- \\
\hline & & $11-06-72$ & Spring & 1,250 & 7.9 & 12.0 & 730 & 210 & 49 & 11 \\
\hline & & & & & & & & & & Blind Bull \\
\hline \multirow[t]{2}{*}{425840110383200} & $35-116-36 b 00$ & $07-12-72$ & Spring & 303 & 7.9 & 6.0 & 140 & 37 & 11 & 9.3 \\
\hline & & & & & & & & & & Hilliard \\
\hline 413758110342000 & 19-116-18bd01 & $10-05-72$ & 100 & 3,790 & 7.5 & 9.0 & 2,000 & 520 & 180 & 240 \\
\hline 415315110333001 & 22-116-15add01 & $06-16-94$ & Spring & 560 & 7.6 & 7.0 & 260 & 70 & 21 & 17 \\
\hline \multirow[t]{2}{*}{415509110355501} & $22-116-05 \mathrm{ada} 01$ & $09-29-71$ & Spring & 630 & -- & 6.0 & -- & -- & -- & -- \\
\hline & & $10-20-77$ & Spring & 880 & 7.4 & 7.0 & 300 & 88 & 19 & 8.0 \\
\hline 415631110325701 & 23-116-26cad01 & $08-02-95$ & Spring & 812 & 7.4 & 7.0 & 380 & 99 & 33 & 47 \\
\hline
\end{tabular}




\begin{tabular}{|c|c|c|c|c|c|c|c|c|c|c|c|}
\hline $\begin{array}{l}\text { Sodium } \\
\text { adsorp- } \\
\text { tion } \\
\text { ratio }\end{array}$ & $\begin{array}{l}\text { Potas- } \\
\text { sium, } \\
\text { dissolved } \\
\text { (K) }\end{array}$ & $\begin{array}{r}\text { Bicar- } \\
\text { bonate } \\
\left(\mathrm{HCO}_{3}\right)\end{array}$ & $\begin{array}{c}\text { Car- } \\
\text { bonate } \\
\left(\mathrm{CO}_{3}\right)\end{array}$ & $\begin{array}{c}\text { Alka- } \\
\text { linity, } \\
\text { total as } \\
\left(\mathrm{CaCO}_{3}\right)\end{array}$ & $\begin{array}{c}\text { Sulfate, } \\
\text { dissolved } \\
\left(\mathrm{SO}_{4}\right)\end{array}$ & $\begin{array}{l}\text { Chloride, } \\
\text { dissolved } \\
\text { (CI) }\end{array}$ & $\begin{array}{l}\text { Fluoride, } \\
\text { dissolved } \\
\text { (F) }\end{array}$ & $\begin{array}{c}\text { Silica, } \\
\text { dissolved } \\
\left(\mathrm{SiO}_{2}\right)\end{array}$ & $\begin{array}{l}\text { Dissolved } \\
\text { solids, } \\
\text { sum of } \\
\text { con- } \\
\text { stituents }\end{array}$ & $\begin{array}{c}\text { Nitrogen, } \\
\mathrm{NO}_{2}+\mathrm{NO}_{3} \\
\text { dissolved } \\
\text { (as } \mathrm{N} \text { ) }\end{array}$ & $\begin{array}{l}\text { Phos- } \\
\text { phorus, } \\
\text { total } \\
\text { (P) }\end{array}$ \\
\hline \multicolumn{12}{|c|}{ Formation--Continued } \\
\hline 56 & 2.7 & -- & -- & 345 & 300 & 250 & 1.8 & 7.1 & 1,180 & .110 & -- \\
\hline-- & -- & -- & -- & -- & -- & -- & -- & -- & -- & -- & - \\
\hline 63 & 6.9 & -- & -- & 180 & 510 & 2,700 & 1.0 & 6.2 & 5,400 & .030 & .010 \\
\hline-- & -- & -- & -- & -- & -- & -- & -- & -- & -- & -- & -- \\
\hline .9 & 2.5 & -- & -- & 254 & 220 & 20 & .20 & 15 & 602 & -- & -- \\
\hline 7 & 1.0 & 333 & 33 & -- & 370 & 18 & .70 & 19 & 915 & -- & -. \\
\hline 1 & 1.4 & -- & -. & 258 & 91 & 28 & .20 & 19 & 422 & -- & -- \\
\hline-- & -- & -- & -. & -. & -- & -- & -- & -- & -- & -- & -- \\
\hline 0 & $<0.1$ & -- & -- & 165 & 14 & 1.1 & .10 & 6.6 & 194 & -- & - \\
\hline-- & -- & -- & -- & -- & -- & -- & -- & -- & -- & -- & -- \\
\hline 1 & 1.9 & -- & -- & 211 & 90 & 5.0 & .20 & 20 & 361 & .180 & $<.010$ \\
\hline 75 & 1.5 & -- & -- & 520 & 220 & 420 & 7.0 & 6.8 & 1,560 & .010 & .030 \\
\hline .1 & .8 & -- & -- & 198 & 3.0 & 0.9 & .10 & 6.1 & 213 & -- & -- \\
\hline 10 & 4.1 & -- & -- & 210 & 260 & 680 & .50 & 10 & 1,660 & .060 & $<.010$ \\
\hline .2 & 1.1 & -- & -- & 173 & 69 & 7.4 & .40 & 6.3 & 272 & .110 & -. \\
\hline .8 & 1.0 & 235 & 0 & -. & 360 & 18 & .40 & 17 & 705 & -- & -- \\
\hline 5 & 3.0 & -- & -- & 417 & 610 & 110 & .80 & 12 & 1,430 & .020 & .010 \\
\hline-- & -- & -- & -- & -- & -- & -- & -- & -- & -- & -- & -- \\
\hline 4 & 4.9 & -- & -- & 304 & 580 & 270 & .80 & 10 & 1,510 & .150 & .010 \\
\hline 11 & 2.2 & -- & -- & 445 & 240 & 98 & 1.6 & 8.7 & 962 & .060 & .040 \\
\hline .1 & 1.4 & -- & -- & 213 & 36 & 2.6 & .20 & 9.0 & 272 & -- & -- \\
\hline \multicolumn{12}{|c|}{ Formation } \\
\hline 1 & 3.1 & -- & -- & 266 & 230 & 30 & .50 & 12 & 625 & -- & -- \\
\hline 56 & 23 & -- & -- & 522 & 1,100 & 1,600 & 2.2 & 4.7 & 4,910 & $<.050$ & .020 \\
\hline .7 & -- & 246 & 0 & -- & 38 & 7.5 & -- & 29 & 295 & -- & -- \\
\hline-- & -- & -- & -- & -- & -- & -- & -- & -- & -- & -- & -- \\
\hline .2 & 1.9 & -- & -- & 140 & 600 & 12 & 1.8 & 8.2 & 978 & -- & -- \\
\hline \multicolumn{12}{|c|}{ Formation } \\
\hline 0.3 & 1.0 & -- & -- & 141 & 21 & 1.0 & 0.40 & 5.7 & 172 & 0.160 & -- \\
\hline \multicolumn{12}{|l|}{ Shale } \\
\hline 2 & 14 & -- & -- & 217 & 2,100 & 140 & .40 & 7.3 & 3,340 & 1.80 & -- \\
\hline .5 & 1.0 & -- & -- & 230 & 62 & 8.1 & .20 & 11 & 323 & -- & -- \\
\hline-- & - & -- & -- & -- & -- & -- & -- & -- & -- & -- & -- \\
\hline .2 & 1.9 & -- & -- & 250 & 50 & 4.5 & .10 & 14 & 333 & .070 & 0.010 \\
\hline 1 & 1.9 & 340 & 0 & 278 & 170 & 25 & .30 & 11 & 554 & -- & -- \\
\hline
\end{tabular}


Table 14. Physical properties and chemical analyses of water samples collected from

\begin{tabular}{|c|c|c|c|c|c|c|c|c|c|c|}
\hline Station number & $\begin{array}{c}\text { Local number } \\
\text { (pl. 3) }\end{array}$ & $\begin{array}{c}\text { Date } \\
\text { sampled }\end{array}$ & $\begin{array}{c}\text { Well } \\
\text { depth } \\
(\mathrm{ft})\end{array}$ & $\begin{array}{c}\text { Specific } \\
\text { conduc- } \\
\text { tance } \\
(\mu \mathrm{S} / \mathrm{cm})\end{array}$ & $\begin{array}{c}\text { pH } \\
\text { (stan- } \\
\text { dard } \\
\text { units) }\end{array}$ & $\begin{array}{l}\text { Water } \\
\text { temper- } \\
\text { ature } \\
\left({ }^{\circ} \mathrm{C}\right) \\
\end{array}$ & $\begin{array}{c}\text { Hard- } \\
\text { ness } \\
\text { (as } \\
\left.\mathrm{CaCO}_{3}\right) \\
\end{array}$ & $\begin{array}{c}\text { Calcium, } \\
\text { dissolved } \\
\text { (Ca) }\end{array}$ & $\begin{array}{c}\text { Magne- } \\
\text { sium, } \\
\text { dissolved } \\
(\mathrm{Mg}) \\
\end{array}$ & $\begin{array}{c}\text { Sodium, } \\
\text { dissolved } \\
(\mathrm{Na})\end{array}$ \\
\hline & & & & & & & & & & Frontier \\
\hline 414053110314501 & $20-116-28 \mathrm{dcc} 01$ & $11-05-76$ & Spring & 1,170 & 9.8 & 6.5 & 5 & 1.4 & 4 & 260 \\
\hline 414440110030001 & $20-112-03 \quad 01$ & $05-26-58$ & Spring & 1,470 & 7.3 & -- & 740 & 190 & 64 & 68 \\
\hline \multirow[t]{2}{*}{415541110363001} & 23-116-32cab01 & $10-20-77$ & Spring & 315 & 7.4 & 6.0 & 170 & 63 & 4.0 & 1.3 \\
\hline & & $06-16-94$ & Spring & 323 & 7.6 & 6.0 & 170 & 60 & 3.8 & 1.4 \\
\hline \multirow[t]{4}{*}{415944110305301} & $23-115-06 \mathrm{ccd} 01$ & $09-29-71$ & Spring & 670 & -- & 6.5 & -- & -- & -- & -- \\
\hline & & $10-20-77$ & Spring & 535 & 8.1 & 5.0 & 200 & 61 & 11 & 44 \\
\hline & & $06-16-94$ & Spring & 721 & 7.7 & 7.0 & -- & -- & -- & -- \\
\hline & & & & & & & & & \multicolumn{2}{|c|}{ Sage Junction } \\
\hline \multirow[t]{2}{*}{413819110565501} & $19-120-11 \mathrm{dcd} 01$ & $05-20-95$ & Spring & 856 & 7.7 & 8.0 & 390 & 100 & 33 & 27 \\
\hline & & & & & & & & & & Aspen \\
\hline \multirow[t]{2}{*}{413450110332201} & $19-116-32 \mathrm{ca} 01$ & $09-11-64$ & Spring & 8,000 & -- & 15.5 & -- & -- & -- & -- \\
\hline & & $06-14-72$ & Spring & 10,200 & 8.4 & 12.5 & 78 & 23 & 5.1 & 2,200 \\
\hline 414406110304801 & 20-116-10bda01 & $06-26-95$ & 100 & 1,460 & 7.7 & 9.0 & 340 & 58 & 47 & 170 \\
\hline \multirow[t]{2}{*}{415427110294701} & 22-115-08bba01 & $11-06-72$ & Spring & 619 & 8.1 & 9.0 & 180 & 51 & 12 & 74 \\
\hline & & $06-14-94$ & Spring & 616 & 8.8 & 8.0 & 51 & 12 & 5.2 & 120 \\
\hline \multirow[t]{2}{*}{420023110285401} & $24-115-32 \mathrm{cbd} 01$ & $10-20-77$ & Spring & 625 & 7.5 & 7.0 & 230 & 66 & 16 & 56 \\
\hline & & 06-16-94 & Spring & 949 & 7.5 & 7.0 & 300 & 90 & 18 & 85 \\
\hline 421541110313801 & 26-115-07bba01 & $07-13-95$ & Spring & 590 & 7.6 & 8.0 & 270 & 77 & 19 & 19 \\
\hline 430635110503401 & $36-117-18 \mathrm{dc} 01$ & $09-14-71$ & Spring & 390 & 7.8 & 12.0 & 180 & 62 & 7.1 & 12 \\
\hline 430806110515401 & NE & $09-10-93$ & Spring & 328 & 7.9 & 9.0 & -- & -- & -- & -- \\
\hline 430816110520501 & $\mathrm{NE}$ & 09-09-93 & Spring & 359 & 7.7 & 9.0 & -- & -- & -- & -- \\
\hline 430846110524200 & $\mathrm{NE}$ & $09-08-71$ & Spring & 336 & 7.5 & 6.5 & 130 & 45 & 5.0 & 21 \\
\hline 431158110520801 & $\mathrm{NE}$ & 08-03-93 & Spring & 326 & 8.5 & 17.0 & -- & -- & -- & -- \\
\hline \multirow[t]{2}{*}{431252110500800} & $\mathrm{NE}$ & $09-08-71$ & Spring & 317 & 7.5 & 6.0 & 140 & 51 & 4.1 & 9.7 \\
\hline & & 09-09-93 & Spring & 330 & 7.6 & 6.0 & 150 & 53 & 4.2 & 9.8 \\
\hline \multirow[t]{3}{*}{431300110483300} & $\mathrm{NE}$ & $09-08-71$ & Spring & 354 & 7.6 & 5.0 & 150 & 54 & 4.6 & 14 \\
\hline & & 09-08-93 & Spring & 353 & 7.7 & 7.0 & 150 & 53 & 4.6 & 14 \\
\hline & & & & & & & & & & Bear River \\
\hline \multirow[t]{2}{*}{414712110275001} & $21-115-21$ add 01 & $11-08-94$ & -- & 692 & 8.3 & 7.0 & 46 & 8.3 & 6.1 & 150 \\
\hline & & $06-17-94$ & -- & 720 & 8.7 & 7.5 & 42 & 6.7 & 6.1 & 150 \\
\hline 415243110281701 & $22-115-21$ baa01 & $06-15-94$ & Spring & 484 & 7.8 & 6.5 & -- & -- & -- & -- \\
\hline \multirow[t]{2}{*}{420928110283201} & $25-115-14 \mathrm{bac} 01$ & $08-14-72$ & Spring & 780 & 7.6 & 7.0 & 390 & 120 & 21 & 24 \\
\hline & & $10-18-77$ & Spring & 510 & 7.3 & 7.5 & 220 & 68 & 12 & 17 \\
\hline 425435110433001 & $34-116-19 \mathrm{~d} 01$ & $09-14-71$ & Spring & 446 & 8.2 & 10.5 & 260 & 76 & 16 & 1.0 \\
\hline 425830110460001 & $35-117-35 \mathrm{a} 01$ & $09-14-71$ & Spring & 402 & 7.8 & 10.5 & 210 & 66 & 12 & 3.5 \\
\hline
\end{tabular}


wells completed in and springs issuing from selected geologic units in Lincoln County, Wyoming--Continued

\begin{tabular}{|c|c|c|c|c|c|c|c|c|c|c|c|}
\hline $\begin{array}{l}\text { Sodium } \\
\text { adsorp- } \\
\text { tion } \\
\text { ratio } \\
\end{array}$ & $\begin{array}{l}\text { Potas- } \\
\text { sium, } \\
\text { dissolved } \\
(\mathbf{K})\end{array}$ & $\begin{array}{r}\text { Bicar- } \\
\text { bonate } \\
\left(\mathrm{HCO}_{3}\right)\end{array}$ & $\begin{array}{c}\text { Car- } \\
\text { bonate } \\
\left(\mathrm{CO}_{3}\right)\end{array}$ & $\begin{array}{c}\text { Alka- } \\
\text { linity, } \\
\text { total as } \\
\left(\mathrm{CaCO}_{3}\right)\end{array}$ & $\begin{array}{c}\text { Sulfate, } \\
\text { dissolved } \\
\left(\mathrm{SO}_{4}\right)\end{array}$ & $\begin{array}{l}\text { Chloride, } \\
\text { dissolved } \\
\text { (Cl) }\end{array}$ & $\begin{array}{l}\text { Fluoride, } \\
\text { dissolved } \\
\text { (F) }\end{array}$ & $\begin{array}{c}\text { Silica, } \\
\text { dissolved } \\
\left(\mathrm{SiO}_{2}\right)\end{array}$ & $\begin{array}{l}\text { Dissolved } \\
\text { solids, } \\
\text { sum of } \\
\text { con- } \\
\text { stituents }\end{array}$ & $\begin{array}{c}\text { Nitrogen, } \\
\mathrm{NO}_{2}+\mathrm{NO}_{3} \text {, } \\
\text { dissolved } \\
\text { (as } \mathrm{N})\end{array}$ & $\begin{array}{c}\text { Phos- } \\
\text { phorus, } \\
\text { total } \\
(P)\end{array}$ \\
\hline \multicolumn{12}{|c|}{ Formation } \\
\hline 50 & 0.5 & -- & -- & 536 & 43 & 9.5 & 5.2 & 12 & 656 & .540 & .040 \\
\hline 1 & -. & 478 & 0 & -- & 400 & 57 & -- & 11 & 1,030 & -- & -- \\
\hline 0 & .4 & -- & -- & 160 & 11 & 0.8 & .10 & 7.3 & 187 & .050 & .030 \\
\hline 0 & .4 & -- & -- & 163 & 12 & 1.0 & .10 & 7.5 & 184 & -- & -- \\
\hline -- & -- & -- & -- & -- & -- & -- & -- & -- & -- & -- & -- \\
\hline 1 & 2.9 & - & -- & 230 & 59 & 13 & .20 & 12 & 341 & .020 & $<.010$ \\
\hline- & -- & -- & -- & -- & & -- & -- & -- & -- & -- & -- \\
\hline \multicolumn{12}{|c|}{ Formation } \\
\hline .6 & 2.0 & -- & -- & 294 & 38 & 65 & .20 & 7.7 & 444 & -- & -- \\
\hline \multicolumn{12}{|l|}{ Shale } \\
\hline- & -- & -- & -- & -- & -- & -- & -- & -- & -- & - & -- \\
\hline 110 & 3.5 & 439 & 4 & -- & 0.8 & 3,100 & 2.0 & 11 & 5,570 & -- & -- \\
\hline 4 & 4.0 & -- & -- & 248 & 230 & 160 & .50 & 9.7 & 875 & 7.90 & $<.010$ \\
\hline 2 & .7 & -- & -- & 258 & 56 & 16 & .60 & 17 & 382 & -- & -- \\
\hline 7 & .4 & -- & -- & 262 & 29 & 21 & 1.2 & 13 & 365 & -- & -- \\
\hline 2 & 1.7 & -- & -- & 230 & 76 & 31 & .50 & 11 & 396 & .050 & .010 \\
\hline 2 & 2.0 & -- & -- & 234 & 130 & 79 & .50 & 10 & 550 & -- & -- \\
\hline .5 & 2.5 & -- & -- & 243 & 37 & 20 & .40 & 12 & 334 & -- & -- \\
\hline .4 & 1.6 & 238 & 0 & -- & 14 & 3.1 & .30 & 8.4 & 228 & -- & -- \\
\hline-- & -- & -- & -- & -- & -- & -- & -- & -- & -- & -- & -- \\
\hline-- & -- & -- & -- & -- & -- & -- & -- & -- & -- & -- & -- \\
\hline .8 & 1.6 & -- & -- & 170 & 9.0 & 1.3 & .30 & 12 & 197 & .060 & -- \\
\hline-- & -- & -- & -- & -- & -- & -- & -- & -- & -- & -- & -- \\
\hline 0.4 & 1.4 & -- & -- & 167 & 6.8 & 0.7 & 0.30 & 17 & 192 & 0.170 & -- \\
\hline .3 & 1.2 & -- & -- & 167 & 6.6 & .6 & .30 & 16 & 195 & -- & -- \\
\hline .5 & 1.6 & -- & -- & 180 & 17 & 1.4 & 1.0 & 9.8 & 212 & .140 & -- \\
\hline .5 & 1.3 & -- & -- & 181 & 12 & .5 & 1.3 & 9.5 & 202 & -- & -- \\
\hline \multicolumn{12}{|c|}{ Formation } \\
\hline 10 & 1.6 & -- & -. & 291 & 68 & 12 & .50 & 9.0 & 430 & -- & -- \\
\hline 10 & 1.1 & -. & -. & 287 & 62 & 20 & .50 & 9.5 & 428 & $-=$ & -- \\
\hline-- & -- & -- & -- & -- & -- & -- & -- & -- & - & -- & -- \\
\hline .5 & 2.7 & -- & -- & -- & 170 & 16 & .50 & 11 & 505 & .200 & -- \\
\hline .5 & 2.3 & -- & -. & -- & 57 & 8.4 & .50 & 9.4 & 283 & .030 & 0.010 \\
\hline 0 & 0.4 & 293 & 0 & -- & 3.3 & 3.1 & .20 & 7.9 & 254 & -- & -- \\
\hline .1 & 1.6 & 247 & 0 & -- & 9.0 & 3.1 & .30 & 7.5 & 226 & -- & -- \\
\hline
\end{tabular}


Table 14. Physical properties and chemical analyses of water samples collected from

\begin{tabular}{|c|c|c|c|c|c|c|c|c|c|c|}
\hline Station number & $\begin{array}{l}\text { Local number } \\
\text { (pl. 3) }\end{array}$ & $\begin{array}{c}\text { Date } \\
\text { sampled }\end{array}$ & $\begin{array}{c}\text { Well } \\
\text { depth } \\
\text { (ft) }\end{array}$ & $\begin{array}{c}\text { Specific } \\
\text { conduc- } \\
\text { tance } \\
(\mu \mathrm{S} / \mathrm{cm})\end{array}$ & $\begin{array}{c}\text { pH } \\
\text { (stan- } \\
\text { dard } \\
\text { units) }\end{array}$ & $\begin{array}{c}\text { Water } \\
\text { temper- } \\
\text { ature } \\
\left({ }^{\circ} \mathrm{C}\right)\end{array}$ & $\begin{array}{c}\text { Hard- } \\
\text { ness } \\
\text { (as } \\
\mathrm{CaCO}_{3} \text { ) }\end{array}$ & $\begin{array}{l}\text { Calcium, } \\
\text { dissolved } \\
\text { (Ca) }\end{array}$ & $\begin{array}{l}\text { Magne- } \\
\text { sium, } \\
\text { dissolved } \\
\text { (Mg) }\end{array}$ & $\begin{array}{l}\text { Sodium, } \\
\text { dissolved } \\
(\mathrm{Na})\end{array}$ \\
\hline & & & & & & & & & & Bear River \\
\hline \multirow[t]{2}{*}{430345110510601} & $36-117-31 \mathrm{bcd} 01$ & $09-14-71$ & Spring & 520 & -- & 6.5 & 240 & 66 & 18 & 7.2 \\
\hline & & $08-11-93$ & Spring & 455 & 7.8 & 7.0 & 230 & 72 & 12 & 7.0 \\
\hline \multirow[t]{2}{*}{430430110503501} & $36-117-30 \mathrm{dbb} 01$ & $09-14-71$ & Spring & 423 & 8.0 & 5.0 & 210 & 64 & 13 & 9.0 \\
\hline & & & & & & & & & \multicolumn{2}{|c|}{ Thomas Fork } \\
\hline \multirow[t]{2}{*}{413819110580101} & $19-120-10 \mathrm{ddc} 01$ & $05-20-95$ & Spring & 670 & -- & 7.0 & -- & -. & -- & - \\
\hline & & & & & & & & & & Gannett \\
\hline 413510111010401 & 19-120-32cbb01 & $05-21-95$ & Spring & 1,030 & -- & 9.0 & -- & -- & - & -- \\
\hline 414321110582801 & $20-120-15$ bad0 1 & $06-20-95$ & Spring & 1,450 & 8.5 & 9.0 & 57 & 7.8 & 9.1 & 280 \\
\hline 415230110270701 & $22-115-22 \mathrm{bda} 01$ & $05-22-94$ & Spring & 396 & 8.3 & 9.5 & 70 & 17 & 6.6 & 60 \\
\hline 415635110282801 & $23-115-29 \mathrm{dbb} 01$ & $06-14-94$ & Spring & 462 & 7.8 & 8.0 & -- & -- & -- & - \\
\hline \multirow[t]{2}{*}{415645110281701} & $23-115-29 \mathrm{acd} 01$ & $10-17-77$ & Spring & 225 & 7.5 & 8.0 & 180 & 49 & 15 & 15 \\
\hline & & $06-14-94$ & Spring & 396 & 7.9 & 8.0 & 190 & 50 & 15 & 15 \\
\hline 420533110533501 & 24-119-28bdb01 & $09-17-71$ & Spring & 587 & 7.5 & 7.0 & 310 & 91 & 21 & 7.6 \\
\hline 421558110571301 & $26-119-02 \mathrm{ccb} 01$ & $07-24-94$ & Spring & 430 & 7.7 & 7.0 & -- & -- & -- & - \\
\hline 421642110431901 & $27-117-34 \mathrm{cdc} 01$ & $07-11-95$ & Spring & 356 & 7.3 & 4.5 & 190 & 59 & 10 & 1.9 \\
\hline 422036110572800 & 27-119-10dab00 & $09-16-71$ & Spring & 438 & 7.6 & 5.0 & 200 & 53 & 16 & 13 \\
\hline 423340110544000 & 30-118-29bb01 & $09-14-71$ & Spring & 407 & 7.6 & 7.0 & 200 & 48 & 19 & 10 \\
\hline 423348110523000 & $30-118-35 \mathrm{ac} 01$ & $07-09-72$ & Spring & 352 & 8.0 & 4.5 & 180 & 57 & 8.8 & 5.1 \\
\hline \multirow[t]{3}{*}{431306110472400} & $\mathrm{NE}$ & $09-08-71$ & Spring & 241 & 7.4 & 7.0 & 100 & 29 & 7.8 & 8.2 \\
\hline & & 09-09-93 & Spring & 240 & 7.7 & 8.0 & 110 & 32 & 7.7 & 5.4 \\
\hline & & & & & & & & & & Stump \\
\hline \multirow[t]{2}{*}{425552110425801} & 34-116-17bdb01 & 09-09-93 & Spring & 437 & 7.7 & 5.0 & 230 & 67 & 15 & 3.0 \\
\hline & & & & & & & & & \multicolumn{2}{|c|}{ Preuss Sandstone } \\
\hline \multirow[t]{2}{*}{422333110575500} & $28-119-27$ bad00 & $09-15-71$ & Spring & 1,350 & 7.6 & 9.0 & 310 & 88 & 21 & 150 \\
\hline & & $09-17-94$ & Spring & 1,170 & 8.3 & 10.0 & - & -- & - & -- \\
\hline 422802110575901 & $29-119-26 \mathrm{cac} 01$ & $07-24-94$ & Spring & 249,000 & 6.9 & 10.0 & 4,100 & 1,300 & 200 & 120,000 \\
\hline \multirow[t]{3}{*}{422828110581200} & 29-119-26bbc01 & $09-15-71$ & Spring & 1,260 & 7.7 & 8.5 & 220 & 70 & 12 & 170 \\
\hline & & 09-15-94 & Spring & 1,670 & 7.7 & 9.0 & - & -. & -- & -- \\
\hline & & & & & & & & & \multicolumn{2}{|r|}{ Twin Creek } \\
\hline 414708110533101 & $21-119-23 \mathrm{acd} 01$ & $06-24-95$ & Spring & 466 & 7.4 & 9.0 & 210 & 65 & 11 & 12 \\
\hline 420906110582301 & $\mathrm{NE}$ & $06-10-95$ & Spring & 595 & 7.6 & 9.0 & 290 & 76 & 25 & 11 \\
\hline 421557110263201 & $26-115-01 \mathrm{cbc} 01$ & $07-13-95$ & Spring & 354 & 7.7 & 5.5 & 190 & 64 & 7.8 & 2.5 \\
\hline 422409110323701 & 28-116-24ada01 & 08-07-94 & Spring & 320 & 7.7 & 6.0 & -- & -- & -- & -- \\
\hline 424730110550000 & $32-118-06 \mathrm{aa0} 1$ & $09-10-71$ & Spring & 526 & 7.6 & 7.0 & 280 & 82 & 18 & 4.0 \\
\hline
\end{tabular}


wells completed in and springs issuing from selected geologic units in Lincoln County, Wyoming--Continued

\begin{tabular}{|c|c|c|c|c|c|c|c|c|c|}
\hline $\begin{array}{c}\text { Sodium } \\
\text { adsorp- } \\
\text { tion } \\
\text { ratio } \\
\end{array}$ & $\begin{array}{l}\text { Potas- } \\
\text { sium, } \\
\text { dissolved } \\
\text { (K) }\end{array}$ & $\begin{array}{r}\text { Bicar- } \\
\text { bonate } \\
\left(\mathrm{HCO}_{3}\right)\end{array}$ & $\begin{array}{c}\text { Car- } \\
\text { bonate } \\
\left(\mathrm{CO}_{3}\right)\end{array}$ & $\begin{array}{c}\text { Alka- } \\
\text { linity, } \\
\text { total as } \\
\left(\mathrm{CaCO}_{3}\right)\end{array}$ & $\begin{array}{c}\text { Sulfate, } \\
\text { dissolved } \\
\left(\mathrm{SO}_{4}\right)\end{array}$ & $\begin{array}{c}\text { Chloride, } \\
\text { dissolved } \\
\text { (CI) }\end{array}$ & $\begin{array}{c}\text { Fluoride, } \\
\text { dissolved } \\
\text { (F) }\end{array}$ & $\begin{array}{c}\text { Silica, } \\
\text { dissolved } \\
\left(\mathrm{SiO}_{2}\right)\end{array}$ & $\begin{array}{l}\text { Dissoly } \\
\text { solid } \\
\text { sum } \\
\text { con- } \\
\text { stituer }\end{array}$ \\
\hline \multicolumn{10}{|c|}{ Formation--Continued } \\
\hline .2 & .9 & 300 & 0 & - & 4.9 & 5.2 & .20 & 8.8 & 257 \\
\hline .2 & .7 & - & -- & 242 & 4.1 & .9 & $<.10$ & 7.9 & 250 \\
\hline .3 & 1.6 & 256 & 0 & -- & 16 & 2.1 & .30 & 7.9 & \\
\hline
\end{tabular}

Formation

Group

\begin{tabular}{|c|c|c|c|c|c|c|c|c|c|c|c|}
\hline -- & -- & -- & -- & -- & -- & -- & -- & -- & -- & -- & -. \\
\hline 16 & 1.1 & -- & -- & 314 & 180 & 140 & 2.3 & 8.5 & 824 & -. & -- \\
\hline 3 & .6 & -- & .. & 181 & 12 & 13 & .30 & 8.2 & 227 & -- & -- \\
\hline -- & -- & -- & -- & -- & -- & -- & -- & -- & -- & -. & -- \\
\hline .5 & 1.2 & -- & -- & 200 & 17 & 6.2 & .20 & 14 & 238 & .460 & .010 \\
\hline .5 & 1.1 & -- & -. & 196 & 9.9 & 7.7 & .20 & 14 & 232 & -- & -- \\
\hline .2 & 1.4 & -- & -- & 175 & 130 & 4.3 & .20 & 14 & 378 & .810 & -- \\
\hline -- & -- & -- & -- & -- & -- & -- & -- & -- & -- & -- & -- \\
\hline .1 & 1.1 & -- & -- & 171 & 3.7 & 4.3 & $<.10$ & 5.1 & 193 & - & -- \\
\hline .4 & .7 & -- & -- & 211 & 7.0 & 7.5 & .20 & 9.7 & 243 & 2.10 & -- \\
\hline .3 & .8 & -- & -- & 220 & 4.0 & 1.7 & .10 & 12 & 228 & .190 & -- \\
\hline .2 & .7 & -- & -- & 194 & 7.1 & 2.1 & 0 & 9.2 & 208 & .320 & -- \\
\hline .3 & 1.0 & -. & -- & 107 & 21 & 1.4 & .20 & 7.6 & 141 & .040 & -- \\
\hline .2 & .8 & -- & -- & 103 & 18 & .9 & .20 & 7.1 & 137 & -- & -- \\
\hline
\end{tabular}

Formation

$\begin{array}{lllll}0.1 & 0.4 & -- & - & 235\end{array}$

$\begin{array}{lllll}4.4 & 0.8 & 0.20 & 9.1 & 232\end{array}$

or Preuss Redbeds

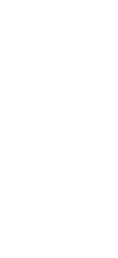

\begin{tabular}{|c|c|c|c|c|c|c|c|c|c|c|c|}
\hline 4 & 2.3 & -- & -- & 226 & 99 & 200 & .20 & 12 & 715 & 1.60 & -- \\
\hline-- & -- & -- & -- & -- & -- & - & -- & -- & -- & -- & -- \\
\hline 820 & 1.7 & -- & -- & 26 & 1,600 & 75,000 & $<.10$ & 14 & 198,000 & -- & -- \\
\hline 5 & 1.2 & -- & -- & 200 & 67 & 210 & .10 & 12 & 664 & 0.350 & -- \\
\hline-- & -- & -- & - & -- & -- & -- & -- & -- & -- & -- & -- \\
\hline \multicolumn{12}{|c|}{ Limestone } \\
\hline .4 & 2.3 & -- & -- & 135 & 75 & 11 & .50 & 15 & 283 & -. & -- \\
\hline .3 & .9 & -- & -- & 219 & 86 & 7.7 & .10 & 14 & 354 & -- & -- \\
\hline .1 & .8 & -- & -- & 189 & 3.0 & 1.4 & .10 & 9.3 & 203 & -- & -- \\
\hline-- & -- & -- & -- & -- & -- & -- & -- & -- & -- & -- & -- \\
\hline .1 & 1.0 & -. & -- & 230 & 67 & 3.1 & .20 & 12 & 326 & .130 & -- \\
\hline
\end{tabular}


Table 14. Physical properties and chemical analyses of water samples collected from

\begin{tabular}{|c|c|c|c|c|c|c|c|c|c|c|}
\hline Station number & $\begin{array}{l}\text { Local number } \\
\text { (pl. 3) }\end{array}$ & $\begin{array}{c}\text { Date } \\
\text { sampled }\end{array}$ & $\begin{array}{c}\text { Well } \\
\text { depth } \\
(\mathrm{ft})\end{array}$ & $\begin{array}{c}\text { Specific } \\
\text { conduc- } \\
\text { tance } \\
(\mu \mathrm{S} / \mathrm{cm})\end{array}$ & $\begin{array}{c}\mathrm{pH} \\
\text { (stan- } \\
\text { dard } \\
\text { units) }\end{array}$ & $\begin{array}{c}\text { Water } \\
\text { temper- } \\
\text { ature } \\
\left({ }^{\circ} \mathrm{C}\right) \\
\end{array}$ & $\begin{array}{c}\text { Hard- } \\
\text { ness } \\
\text { (as } \\
\mathrm{CaCO}_{3} \text { ) }\end{array}$ & $\begin{array}{c}\text { Calcium, } \\
\text { dissolved } \\
\text { (Ca) }\end{array}$ & $\begin{array}{l}\text { Magne- } \\
\text { sium, } \\
\text { dissolved } \\
(\mathrm{Mg})\end{array}$ & $\begin{array}{c}\text { Sodium, } \\
\text { dissolved } \\
\text { (Na) }\end{array}$ \\
\hline & & & & & & & & & & Nugget \\
\hline 414721110503401 & $21-118-20 b b d 01$ & $06-21-95$ & Spring & 61 & 6.2 & 7.0 & 25 & 7.7 & 1.3 & 2.3 \\
\hline \multirow[t]{2}{*}{415540110511300} & $23-118-31 \mathrm{dca} 00$ & $06-24-75$ & Spring & 229 & 7.4 & 6.5 & 100 & 31 & 5.8 & 8.0 \\
\hline & & $06-17-93$ & Spring & 288 & 7.2 & 7.0 & -- & -- & -- & -- \\
\hline 415616110512001 & $23-118-30 \mathrm{dcc} 01$ & $06-17-93$ & Spring & 315 & 7.8 & 8.0 & 200 & 61 & 12 & 7.2 \\
\hline 415704111003701 & $23-120-26 a b 01$ & $04-16-56$ & Spring & 1,270 & 7.6 & 6.0 & 360 & 77 & 40 & 150 \\
\hline 420120110250301 & $24-115-35 a b c 01$ & $06-16-94$ & Spring & 376 & 7.8 & 7.0 & 180 & 57 & 9.1 & 8.0 \\
\hline 420429110504301 & $24-118-08 \mathrm{cba} 01$ & $06-11-95$ & Spring & 591 & 8.1 & 8.0 & 290 & 71 & 27 & 6.8 \\
\hline 420430110505701 & 24-118-07daa01 & $06-11-95$ & Spring & 548 & 8.1 & 7.0 & -- & -- & -- & -- \\
\hline 421211110261901 & $26-115-26 \mathrm{adc} 01$ & $10-18-77$ & Spring & 380 & 7.2 & 7.0 & 180 & 64 & 5.9 & 3.8 \\
\hline 421313110255001 & $26-115-24 \mathrm{dcd} 01$ & $07-29-95$ & Spring & 299 & 7.8 & 6.0 & 150 & 50 & 5.8 & 3.6 \\
\hline \multirow[t]{2}{*}{421405110275601} & $26-115-15 \mathrm{cdb} 01$ & $10-18-77$ & Spring & 320 & 8.0 & 5.0 & 170 & 51 & 11 & 4.3 \\
\hline & & $07-13-95$ & Spring & 260 & 7.9 & 6.0 & 150 & 44 & 8.9 & 3.4 \\
\hline \multirow[t]{2}{*}{422821110395800} & $29-116-28 b c b 00$ & $10-15-71$ & Spring & 185 & 8.0 & 3.5 & 95 & 29 & 5.5 & 1.4 \\
\hline & & $08-07-94$ & Spring & 180 & 8.3 & 3.0 & -- & -- & -- & -- \\
\hline 423632110394401 & $\mathrm{NE}$ & $07-07-72$ & Spring & 178 & 8.1 & 4.5 & 93 & 25 & 7.5 & 1.5 \\
\hline \multirow[t]{2}{*}{423645110395401} & $\mathrm{NE}$ & $09-14-71$ & Spring & 210 & -- & 4.5 & 91 & 29 & 4.4 & 1.5 \\
\hline & & $08-02-94$ & Spring & 180 & 8.0 & 4.5 & 91 & 25 & 7.0 & 1.6 \\
\hline 423654110393901 & $\mathrm{NE}$ & $09-10-93$ & Spring & 253 & 8.3 & 4.5 & -- & -- & -- & -- \\
\hline 424356110394201 & NE & $07-15-72$ & Spring & 605 & 6.8 & 5.0 & 320 & 89 & 23 & 2.1 \\
\hline 424647110550501 & $32-118-07 \mathrm{aba01}$ & $08-07-94$ & 230 & 462 & 7.8 & 11.0 & 240 & 50 & 27 & 3.6 \\
\hline 430602110423501 & $\mathrm{NE}$ & $08-12-93$ & Spring & 239 & 7.8 & 7.5 & 110 & 24 & 12 & 5.7 \\
\hline \multirow[t]{3}{*}{430713110425401} & $\mathrm{NE}$ & $09-14-71$ & Spring & 180 & -- & 5.0 & 130 & 39 & 6.8 & 1.5 \\
\hline & & $08-12-93$ & Spring & 245 & 7.7 & 6.0 & -- & -- & -- & -- \\
\hline & & & & & & & & & & Thaynes \\
\hline \multirow[t]{3}{*}{415242110502001} & $22-118-17 \mathrm{dcc} 01$ & $06-07-65$ & 600 & 543 & 7.7 & -- & 260 & 47 & 34 & 18 \\
\hline & & $09-22-71$ & 600 & 631 & 7.4 & 10.0 & 310 & 69 & 33 & 18 \\
\hline & & $06-16-93$ & 600 & 610 & -- & 11.0 & -- & -- & -- & $\cdots$ \\
\hline 415304110501601 & $22-118-17 \mathrm{dbb} 01$ & $06-16-93$ & Spring & 609 & 7.4 & 8.5 & 300 & 75 & 28 & 12 \\
\hline 420837110490801 & $25-118-23 \mathrm{aba0} 1$ & $06-24-95$ & Spring & 391 & 7.9 & 6.5 & 210 & 57 & 16 & 3.4 \\
\hline 420958110242401 & 25-114-08daa01 & $07-30-95$ & Spring & 535 & 7.9 & 7.0 & -- & -- & -- & $-\cdot$ \\
\hline \multirow[t]{2}{*}{423116110420901} & $29-116-07 \mathrm{bbb01}$ & $08-25-71$ & Spring & 280 & -- & 4.5 & $\cdots$ & -. & -- & -- \\
\hline & & $08-04-93$ & Spring & 295 & 7.9 & 3.0 & -- & - & -- & -- \\
\hline 423435110440501 & $\mathrm{NE}$ & $08-04-93$ & Spring & 236 & 7.9 & 4.0 & 120 & 35 & 8.6 & 1.0 \\
\hline 424955110595500 & $33-119-23 \mathrm{ac} 01$ & $09-10-71$ & Spring & 8,640 & 6.6 & 55.0 & 1,300 & 420 & 69 & 1,400 \\
\hline 425003110595001 & 33-119-23abd01 & $07-26-92$ & 195 & 409 & 7.6 & 21.0 & -- & -- & -- & -- \\
\hline
\end{tabular}




\begin{tabular}{|c|c|c|c|c|c|c|c|c|c|c|c|}
\hline $\begin{array}{c}\text { Sodium } \\
\text { adsorp- } \\
\text { tion } \\
\text { ratio }\end{array}$ & $\begin{array}{l}\text { Potas- } \\
\text { sium, } \\
\text { dissolved } \\
\text { (K) }\end{array}$ & $\begin{array}{c}\text { Bicar- } \\
\text { bonate } \\
\left(\mathrm{HCO}_{3}\right)\end{array}$ & $\begin{array}{c}\text { Car- } \\
\text { bonate } \\
\left(\mathrm{CO}_{3}\right)\end{array}$ & $\begin{array}{l}\text { Alka- } \\
\text { linity, } \\
\text { total as } \\
\left(\mathrm{CaCO}_{3}\right)\end{array}$ & $\begin{array}{c}\text { Sulfate, } \\
\text { dissolved } \\
\left(\mathrm{SO}_{4}\right)\end{array}$ & $\begin{array}{c}\text { Chloride, } \\
\text { dissolved } \\
\text { (CI) }\end{array}$ & $\begin{array}{l}\text { Fluoride, } \\
\text { dissolved } \\
\text { (F) }\end{array}$ & $\begin{array}{c}\text { Silica, } \\
\text { dissolved } \\
\left(\mathrm{SiO}_{2}\right)\end{array}$ & $\begin{array}{l}\text { Dissolved } \\
\text { solids, } \\
\text { sum of } \\
\text { con- } \\
\text { stituents }\end{array}$ & $\begin{array}{c}\text { Nitrogen, } \\
\mathrm{NO}_{2}+\mathrm{NO}_{3}, \\
\text { dissolved } \\
\text { (as } \mathrm{N} \text { ) }\end{array}$ & $\begin{array}{l}\text { Phos- } \\
\text { phorus, } \\
\text { total } \\
\text { (P) }\end{array}$ \\
\hline \multicolumn{12}{|c|}{ Sandstone } \\
\hline .2 & .5 & -- & -- & 19 & 4.1 & 1.9 & $<.10$ & 9.1 & 40 & -- & -- \\
\hline .3 & 1.6 & -- & $\cdots$ & 98 & 9.1 & 9.1 & .20 & 17 & 141 & - & -- \\
\hline-- & -- & -- & -- & -- & -- & -- & -- & -- & -- & -- & -- \\
\hline .2 & 1.3 & -- & -- & 153 & 13 & 11 & .20 & 13 & 210 & -- & -- \\
\hline 3 & -- & 366 & 0 & -- & 330 & 50 & -- & -- & 824 & -- & -- \\
\hline .3 & 1.0 & -. & -. & 175 & 9.0 & 11 & $<.10$ & 8.0 & 211 & - & -- \\
\hline .2 & .8 & -- & - & 203 & 110 & 3.8 & .20 & 14 & 360 & -- & -- \\
\hline-- & -- & -- & - & -- & -. & -- & -- & -- & -- & - & -- \\
\hline .1 & .9 & -- & -- & 190 & 4 & 2.7 & .10 & 11 & 209 & .610 & .010 \\
\hline .1 & .8 & 184 & 0 & 151 & 3 & 2.5 & $<.10$ & 13 & 170 & -. & -- \\
\hline .1 & 6 & -- & -- & 170 & 5 & 3.2 & .10 & 18 & 198 & .250 & .040 \\
\hline .1 & .7 & -- & -- & 140 & 3 & 2.4 & .90 & 14 & 165 & - & -- \\
\hline .1 & .9 & -- & - & 100 & 2.8 & 1.2 & ND & 5.3 & 107 & .130 & -- \\
\hline-- & -- & -. & -- & -- & -- & - & -- & - & -. & -- & -. \\
\hline .1 & .9 & 106 & 0 & -- & 4.1 & 1.7 & .10 & 8.5 & 104 & -- & -- \\
\hline .1 & .4 & 110 & 0 & -- & 4.9 & 2.1 & .20 & 8.0 & 103 & -. & -- \\
\hline .1 & .3 & -- & -- & 87 & 7.2 & .5 & .20 & 7.6 & 103 & -. & -- \\
\hline-- & -- & -- & -- & -- & -- & -- & -- & -- & -- & -- & -- \\
\hline 0 & .4 & 153 & 0 & -- & 190 & 1.0 & .30 & 7.1 & 388 & -- & -- \\
\hline 0.1 & 1.3 & -- & -- & 175 & 69 & 2.5 & 0.20 & 10 & 270 & $<0.050$ & $<0.010$ \\
\hline .2 & 0.7 & -- & -- & 102 & 19 & 0.9 & $<.10$ & 9.5 & 134 & -- & - \\
\hline .1 & .9 & 150 & 0 & - & 2.5 & 2.1 & .20 & 10 & 136 & -. & -- \\
\hline-- & -- & -- & $\cdots$ & -- & -- & -- & -- & -- & -- & -- & -- \\
\hline \multicolumn{12}{|c|}{ Limestone } \\
\hline .5 & 3.9 & -- & $\cdots$ & 179 & 97 & 10 & .50 & 13 & 331 & -- & - \\
\hline .4 & 3.1 & -- & $-\cdot$ & 240 & 97 & 7.7 & .40 & 14 & 386 & .020 & -- \\
\hline-- & -- & -- & -- & -- & -- & - & -- & -- & -- & -- & -- \\
\hline .3 & 2.1 & -- & - & 230 & 95 & 8.3 & .30 & 9.5 & 351 & -- & -. \\
\hline .1 & .6 & - & - & 197 & 9.0 & 1.6 & .10 & 9.5 & 222 & -. & - \\
\hline-- & -- & - & $\cdots$ & -- & -- & -- & -- & -- & -- & $\cdots$ &.- \\
\hline-- & -. & -- & -- & - & -. & -. & -- & -- & -- & -- & - \\
\hline-- & - & -- & - & -- & - & -- & -- & -- & -- & -- & -- \\
\hline 0 & .2 & -- & - & 119 & 6.2 & .3 & $<.10$ & 4.7 & 128 & -- & -- \\
\hline 171 & 50 & -- & -- & 681 & 1,300 & 1,900 & .20 & 40 & 5,690 & .050 & -- \\
\hline-- & -- & -- & -- & -- & -- & -- & - & - & -- & -- & -- \\
\hline
\end{tabular}


Table 14. Physical properties and chemical analyses of water samples collected from

\begin{tabular}{|c|c|c|c|c|c|c|c|c|c|c|}
\hline Station number & $\begin{array}{l}\text { Local number } \\
\text { (pl. 3) }\end{array}$ & $\begin{array}{c}\text { Date } \\
\text { sampled }\end{array}$ & $\begin{array}{c}\text { Well } \\
\text { depth } \\
(\mathrm{ft})\end{array}$ & $\begin{array}{c}\text { Specific } \\
\text { conduc- } \\
\text { tance } \\
(\mu \mathrm{S} / \mathrm{cm})\end{array}$ & $\begin{array}{c}\text { pH } \\
\text { (stan- } \\
\text { dard } \\
\text { units) }\end{array}$ & $\begin{array}{l}\text { Water } \\
\text { temper- } \\
\text { ature } \\
\left({ }^{\circ} \mathrm{C}\right)\end{array}$ & $\begin{array}{c}\text { Hard- } \\
\text { ness } \\
\text { (as } \\
\left.\mathrm{CaCO}_{3}\right)\end{array}$ & $\begin{array}{l}\text { Calcium, } \\
\text { dissolved } \\
\text { (Ca) }\end{array}$ & $\begin{array}{l}\text { Magne- } \\
\text { sium, } \\
\text { dissolved } \\
(\mathrm{Mg})\end{array}$ & $\begin{array}{l}\text { Sodium, } \\
\text { dissolved } \\
\text { (Na) }\end{array}$ \\
\hline & & & & & & & & & & Woodside \\
\hline 420408110493601 & $24-118-09 \mathrm{ccc} 01$ & $06-11-95$ & Spring & 430 & 7.7 & 9.0 & -- & -- & -- & -- \\
\hline 420415110494401 & 24-118-08dda01 & $06-11-95$ & Spring & 515 & 7.8 & 6.5 & 250 & 54 & 28 & 5.7 \\
\hline \multirow[t]{2}{*}{424946110594001} & 33-119-23daa01 & $07-26-92$ & -- & 444 & 7.5 & 22.0 & -- & -- & -- & -- \\
\hline & & & & & & & & & & Dinwoody \\
\hline 422327110361901 & $28-116-28 \mathrm{aac} 01$ & $09-16-94$ & Spring & 271 & 8.0 & 5.0 & -- & -- & -- & -- \\
\hline \multirow[t]{2}{*}{423126110420401} & $29-116-06 \mathrm{cca} 01$ & $08-05-93$ & Spring & 174 & 8.4 & 5.0 & 90 & 23 & 8.0 & 0.7 \\
\hline & & & & & & & & \multicolumn{3}{|c|}{${ }^{2}$ Phosphoria Formation } \\
\hline 415150110495501 & $22-118-29 a a b 01$ & $06-11-65$ & 530 & 4,830 & 7.8 & - & 2,400 & 530 & 260 & 420 \\
\hline \multirow[t]{2}{*}{415230110494801} & 22-118-20ad01 & $09-22-71$ & Spring & 1,650 & 7.5 & 9.5 & 840 & 230 & 65 & 70 \\
\hline & & & & & & & & & & Tensleep \\
\hline 430800110412700 & NE & $07-10-72$ & Spring & 264 & 7.6 & 4.0 & 140 & 41 & 9.2 & .3 \\
\hline \multirow[t]{3}{*}{431158110562500} & $\mathrm{NE}$ & $09-08-71$ & Spring & 309 & 7.9 & 6.0 & 170 & 41 & 16 & 1.0 \\
\hline & & $09-08-93$ & Spring & 294 & 8.0 & 5.0 & 160 & 39 & 15 & .7 \\
\hline & & & & & & & & & & Wells \\
\hline 414950111013001 & 21-120-10da01 & $09-23-71$ & 191 & 839 & 7.4 & 14.0 & 330 & 75 & 34 & 50 \\
\hline \multirow[t]{2}{*}{421443110470400} & $26-117.5-13$ bad00 & $09-11-71$ & Spring & 237 & 7.7 & 3.5 & 130 & 37 & 8.2 & 1.8 \\
\hline & & $09-13-94$ & Spring & 237 & 8.0 & 5.0 & 120 & 33 & 8.0 & 1.8 \\
\hline 423155110421501 & $\mathrm{NE}$ & $09-14-71$ & Spring & 178 & 8.1 & 4.0 & 90 & 27 & 5.6 & 0.5 \\
\hline \multirow[t]{2}{*}{423230110421501} & NE & $09-14-71$ & Spring & 210 & -- & 3.5 & 100 & 29 & 6.8 & .5 \\
\hline & & $08-04-93$ & Spring & 188 & 7.2 & 4.5 & 96 & 23 & 9.3 & 6 \\
\hline \multirow[t]{2}{*}{425132110380301} & $33-116-12 b 01$ & $07-13-72$ & Spring & 310 & 6.6 & 4.5 & 170 & 45 & 13 & .9 \\
\hline & & & & & & & & & & Madison \\
\hline \multirow[t]{3}{*}{421702110201501} & 26-114-01bac01 & $09-15-65$ & Spring & 355 & 7.7 & - & 180 & 46 & 16 & 1.2 \\
\hline & & $08-17-76$ & Spring & 375 & 7.3 & 10.0 & - & -- & -- & -- \\
\hline & & $11-18-76$ & Spring & -- & 7.5 & 8.0 & 190 & 48 & 17 & 2.3 \\
\hline 423148110411601 & 29-116-06add01 & $08-05-93$ & Spring & 506 & 8.0 & 6.0 & 270 & 72 & 21 & .8 \\
\hline \multirow[t]{2}{*}{424440110505001} & $\mathrm{NE}$ & $09-14-71$ & Spring & 186 & 8.2 & 4.0 & 93 & 29 & 5.0 & ND \\
\hline & & $10-04-93$ & Spring & 189 & 8.3 & 4.5 & 98 & 25 & 8.6 & .4 \\
\hline 425040110513000 & $33-118-13 \operatorname{acc} 01$ & $09-10-71$ & Spring & 338 & 7.8 & 5.0 & 170 & 46 & 14 & .8 \\
\hline \multirow[t]{2}{*}{430838110582200} & $37-118-34 \mathrm{dcd} 00$ & $09-08-71$ & Spring & 360 & 8.1 & 6.0 & 200 & 41 & 24 & 1.6 \\
\hline & & & & & & & & & & Darby \\
\hline 425951110562201 & $\mathrm{NE}$ & $09-15-94$ & Spring & 287 & 8.3 & 4.0 & 160 & 36 & 16 & .4 \\
\hline
\end{tabular}


wells completed in and springs issuing from selected geologic units in Lincoln County, Wyoming--Continued

\begin{tabular}{|c|c|c|c|c|c|c|c|c|c|c|c|}
\hline $\begin{array}{l}\text { Sodium } \\
\text { adsorp- } \\
\text { tion } \\
\text { ratio } \\
\end{array}$ & $\begin{array}{c}\text { Potas- } \\
\text { sium, } \\
\text { dissolved } \\
\text { (K) }\end{array}$ & $\begin{array}{r}\text { Bicar- } \\
\text { bonate } \\
\left(\mathrm{HCO}_{3}\right)\end{array}$ & $\begin{array}{c}\text { Car- } \\
\text { bonate } \\
\left(\mathrm{CO}_{3}\right) \\
\end{array}$ & $\begin{array}{c}\text { Alka- } \\
\text { linity, } \\
\text { total as } \\
\left(\mathrm{CaCO}_{3}\right)\end{array}$ & $\begin{array}{c}\text { Sulfate, } \\
\text { dissolved } \\
\left(\mathrm{SO}_{4}\right)\end{array}$ & $\begin{array}{l}\text { Chloride, } \\
\text { dissolved } \\
\text { (CI) }\end{array}$ & $\begin{array}{c}\text { Fluoride, } \\
\text { dissolved } \\
\text { (F) }\end{array}$ & $\begin{array}{c}\text { Silica, } \\
\text { dissolved } \\
\left(\mathrm{SiO}_{2}\right) \\
\end{array}$ & $\begin{array}{l}\text { Dissolved } \\
\text { solids, } \\
\text { sum of } \\
\text { con- } \\
\text { stituents } \\
\end{array}$ & $\begin{array}{c}\text { Nitrogen, } \\
\mathrm{NO}_{2}+\mathrm{NO}_{3}, \\
\text { dissolved } \\
\text { (as } \mathrm{N} \text { ) }\end{array}$ & $\begin{array}{c}\text { Phos- } \\
\text { phorus, } \\
\text { total } \\
(P) \\
\end{array}$ \\
\hline \multicolumn{12}{|l|}{ Shale } \\
\hline-- & -- & -- & -- & -- & -- & -- & -- & -- & -- & -- & -- \\
\hline .2 & 1.0 & -- & -- & 215 & 56 & 3.6 & .30 & 11 & 293 & -- & -- \\
\hline-- & -- & -- & -- & -- & -- & -- & -- & -- & -- & -- & -- \\
\hline \multicolumn{12}{|c|}{ Formation } \\
\hline-- & -- & -- & -- & -- & -- & -- & -- & -- & -- & -- & -- \\
\hline 0 & .4 & - & -- & 91 & 4.1 & .4 & .30 & 5.3 & 91 & -- & -- \\
\hline \multicolumn{12}{|c|}{ and related rocks } \\
\hline 4 & 51 & -. & -- & 146 & 2,600 & 360 & 2.6 & 8.3 & 4,340 & -- & -. \\
\hline 1 & 7.9 & -- & -- & 238 & 650 & 51 & .80 & 9.2 & 1,230 & .130 & -- \\
\hline \multicolumn{12}{|c|}{ Sandstone } \\
\hline 0 & .3 & -- & -- & 135 & 3.1 & 1.0 & .40 & 4.5 & 143 & .380 & -- \\
\hline 0 & .3 & -- & -- & 167 & 3.3 & .9 & .10 & 5.4 & 171 & .510 & -- \\
\hline 0 & .3 & -- & -- & 161 & 3.1 & .4 & .10 & 5.0 & 161 & -- & -- \\
\hline \multicolumn{12}{|c|}{ Formation } \\
\hline 1 & 3.1 & -- & -- & 225 & 160 & 48 & 0.50 & 12 & 521 & 0.830 & -- \\
\hline 0.1 & 0.7 & -- & -- & 118 & 1.0 & 1.4 & .20 & 8.3 & 131 & .390 & -- \\
\hline .1 & .4 & -- & -- & 108 & 13 & 0.7 & $<.10$ & 7.9 & 132 & -- & -- \\
\hline 0 & .7 & 104 & 0 & -- & 4.1 & 1.0 & .40 & 5.8 & 100 & -- & -- \\
\hline 0 & .2 & 110 & 0 & -- & 12 & 3.1 & .30 & 5.3 & 110 & -- & -- \\
\hline 0 & .3 & -- & -- & 85 & 11 & .3 & .20 & 4.8 & 102 & -- & -- \\
\hline 0 & .3 & 196 & 0 & -- & 10 & 1.0 & .30 & 3.3 & 171 & -- & -- \\
\hline \multicolumn{12}{|c|}{ Limestone } \\
\hline 0 & .4 & -- & -- & 162 & 19 & .8 & .30 & 5.4 & 186 & -- & -. \\
\hline-- & -- & -- & -- & -- & -- & -- & -- & -- & -- & -- & -- \\
\hline .1 & .6 & -- & -- & 160 & 28 & 3.1 & .30 & 5.8 & 199 & .100 & 0.010 \\
\hline 0 & .6 & -- & -- & 163 & 120 & .9 & .40 & 4.9 & 311 & -- & -- \\
\hline 0 & .7 & 101 & 0 & -- & 9.9 & 1.0 & .50 & 4.3 & 104 & -- & -- \\
\hline 0 & .2 & -- & -- & 85 & 11 & .6 & .40 & 4.0 & 105 & -- & -- \\
\hline 0 & .5 & -- & -- & 162 & 28 & 1.1 & .30 & 5.6 & 195 & .220 & -- \\
\hline 0 & .6 & -- & -- & 203 & 3.8 & .7 & .10 & 7.9 & 202 & .100 & -- \\
\hline
\end{tabular}

Formation

0

$\begin{array}{llll}.3 & - & -- & 157\end{array}$

$\begin{array}{lll}1.5 & .4 & <.10\end{array}$

3.5

155 
Table 14. Physical properties and chemical analyses of water samples collected from

\begin{tabular}{|c|c|c|c|c|c|c|c|c|c|c|}
\hline Station number & $\begin{array}{c}\text { Local number } \\
\text { (pl. 3) }\end{array}$ & $\begin{array}{c}\text { Date } \\
\text { sampled }\end{array}$ & $\begin{array}{c}\text { Well } \\
\text { depth } \\
\text { (ft) }\end{array}$ & $\begin{array}{c}\text { Specific } \\
\text { conduc- } \\
\text { tance } \\
(\mu \mathrm{S} / \mathrm{cm})\end{array}$ & $\begin{array}{c}\mathrm{pH} \\
\text { (stan- } \\
\text { dard } \\
\text { units) }\end{array}$ & $\begin{array}{c}\text { Water } \\
\text { temper- } \\
\text { ature } \\
\left({ }^{\circ} \mathrm{C}\right) \\
\end{array}$ & $\begin{array}{c}\text { Hard- } \\
\text { ness } \\
\text { (as } \\
\left.\mathrm{CaCO}_{3}\right) \\
\end{array}$ & $\begin{array}{c}\text { Calcium, } \\
\text { dissolved } \\
\text { (Ca) }\end{array}$ & $\begin{array}{c}\text { Magne- } \\
\text { sium, } \\
\text { dissolved } \\
(\mathrm{Mg}) \\
\end{array}$ & $\begin{array}{c}\text { Sodium, } \\
\text { dissolved } \\
(\mathrm{Na})\end{array}$ \\
\hline & & & & & & & & & & Bighorn \\
\hline 421504110183101 & $26-113-07 \mathrm{c} 01$ & $10-18-77$ & Spring & 500 & 7.2 & 9.0 & 270 & 59 & 30 & 6.9 \\
\hline \multirow[t]{2}{*}{421509110185301} & 26-113-07bda01 & $10-18-77$ & Spring & 400 & 7.6 & 8.0 & 220 & 46 & 25 & 6.0 \\
\hline & & $07-27-95$ & Spring & 452 & 8.0 & 7.5 & 210 & 44 & 25 & 10 \\
\hline \multirow[t]{3}{*}{421612110182301} & 26-113-06ada01 & $08-10-86$ & Spring & 420 & 7.3 & 7.5 & 210 & 47 & 23 & 5.2 \\
\hline & & $07-12-95$ & Spring & 350 & 7.7 & 8.0 & 250 & 57 & 27 & 12 \\
\hline & & $07-12-95$ & Spring & 350 & 7.7 & 8.0 & 260 & 57 & 28 & 12 \\
\hline 425420110522001 & 34-118-26aad01 & $09-10-71$ & Spring & 281 & 8.0 & 4.5 & 150 & 35 & 14 & ND \\
\hline \multirow[t]{2}{*}{431200111014500} & $37-118-18 \mathrm{aab} 00$ & $09-08-71$ & Spring & 340 & 7.7 & 6.5 & 200 & 51 & 18 & .9 \\
\hline & & $08-12-93$ & Spring & 369 & 7.6 & 5.0 & -- & -- & -- & -- \\
\hline 430157110580500 & NE & $09-10-71$ & Spring & 245 & 7.8 & 4.5 & 150 & 35 & 14 & 1.2 \\
\hline
\end{tabular}

${ }^{\mathrm{I}}$ This well was part of a baseline ground-water monitoring program in Star Valley. Additional chemcial analyses for each site are available in Table 16.

${ }^{2}$ In Wyoming, the Phosphoria Formation is synonymous with the Park City Formation (Lane, 1973, p. 4) 
wells completed in and springs issuing from selected geologic units in Lincoln County, Wyoming--Continued

\begin{tabular}{|c|c|c|c|c|c|c|c|c|c|c|c|}
\hline $\begin{array}{l}\text { Sodium } \\
\text { adsorp- } \\
\text { tion } \\
\text { ratio }\end{array}$ & $\begin{array}{l}\text { Potas- } \\
\text { sium, } \\
\text { dissolved } \\
\text { (K) }\end{array}$ & $\begin{array}{l}\text { Bicar- } \\
\text { bonate } \\
\left(\mathrm{HCO}_{3}\right)\end{array}$ & $\begin{array}{c}\text { Car- } \\
\text { bonate } \\
\left(\mathrm{CO}_{3}\right)\end{array}$ & $\begin{array}{c}\text { Alka- } \\
\text { linity, } \\
\text { total as } \\
\left(\mathrm{CaCO}_{3}\right)\end{array}$ & $\begin{array}{l}\text { Sulfate, } \\
\text { dissolved } \\
\left(\mathrm{SO}_{4}\right)\end{array}$ & $\begin{array}{l}\text { Chloride, } \\
\text { dissolved } \\
\text { (CI) }\end{array}$ & $\begin{array}{l}\text { Fluoride, } \\
\text { dissolved } \\
\text { (F) }\end{array}$ & $\begin{array}{c}\text { Silica, } \\
\text { dissolved } \\
\left(\mathrm{SiO}_{2}\right)\end{array}$ & $\begin{array}{l}\text { Dissolved } \\
\text { solids, } \\
\text { sum of } \\
\text { con- } \\
\text { stituents }\end{array}$ & $\begin{array}{c}\text { Nitrogen, } \\
\mathrm{NO}_{2}+\mathrm{NO}_{3} \\
\text { dissolved } \\
\text { (as } \mathrm{N} \text { ) }\end{array}$ & $\begin{array}{l}\text { Phos- } \\
\text { phorus, } \\
\text { total } \\
\text { (P) }\end{array}$ \\
\hline \multicolumn{12}{|l|}{ Dolomite } \\
\hline .2 & 1.3 & -- & -- & 230 & 33 & 10 & .10 & 8.3 & 287 & .150 & .010 \\
\hline .2 & .7 & -- & -. & 180 & 22 & 7.7 & .10 & 7.6 & 226 & .650 & .010 \\
\hline .3 & .8 & -- & -- & 172 & 40 & 15 & .20 & 6.4 & 249 & .970 & $<.010$ \\
\hline .2 & .6 & -- & -- & 191 & 23 & 6.7 & .10 & 6.3 & 229 & .560 & -- \\
\hline .3 & .4 & -- & -- & 191 & 56 & 18 & .10 & 7.0 & 293 & -- & -- \\
\hline .3 & .4 & -- & -- & 191 & 55 & 18 & .10 & 7.0 & 294 & -- & -- \\
\hline 0 & .4 & 146 & 0 & -- & 21 & .6 & .20 & 7.4 & 153 & -- & -- \\
\hline 0 & .5 & -- & -- & 206 & 1.3 & 1.5 & .10 & 5.4 & 203 & .240 & -- \\
\hline-- & -- & -- & -- & -- & -- & -- & -- & -- & -- & -- & -- \\
\hline 0 & .7 & -- & -- & 148 & 6.3 & 1.3 & .0 & 4.2 & 153 & .200 & -- \\
\hline
\end{tabular}




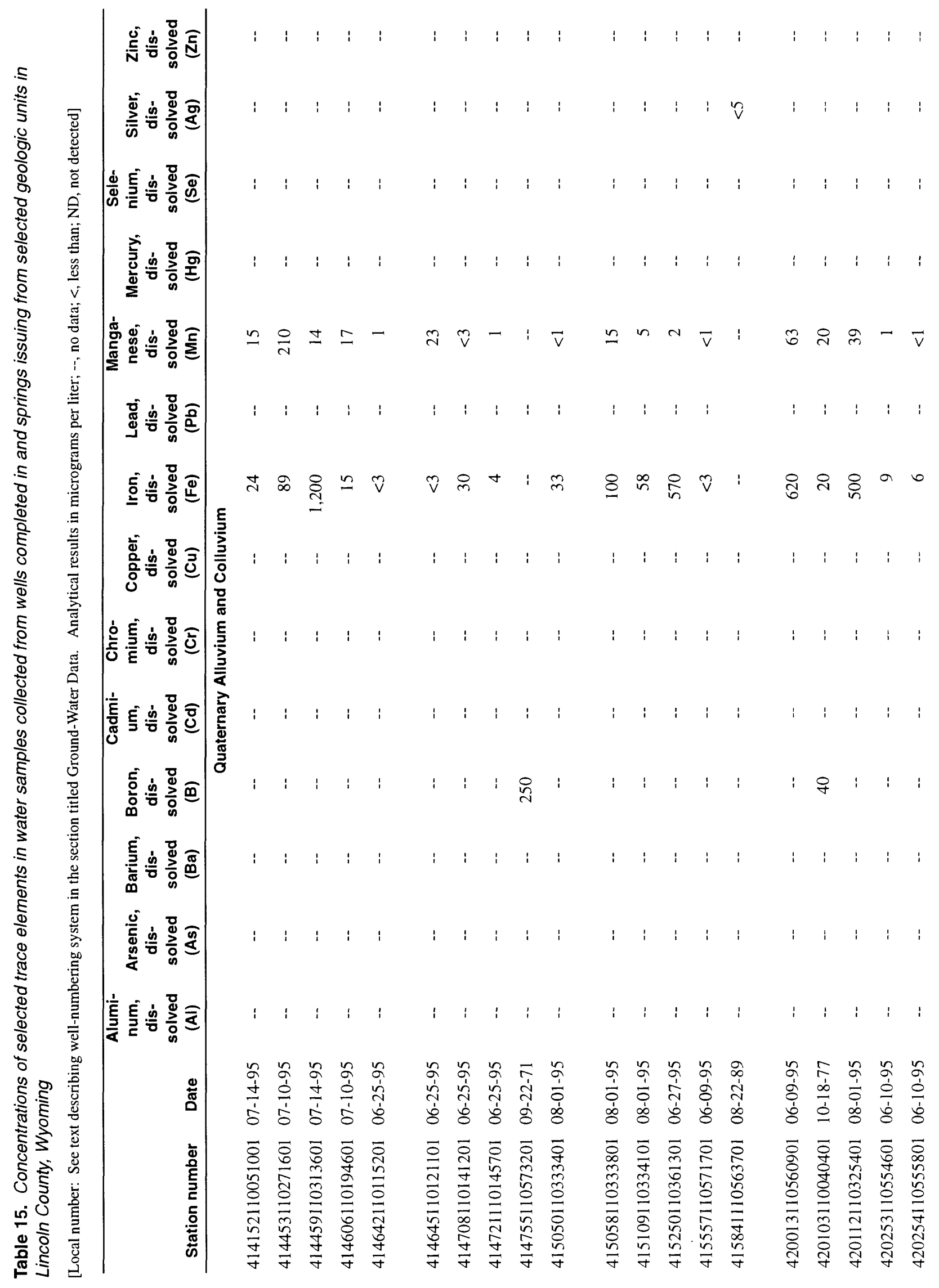




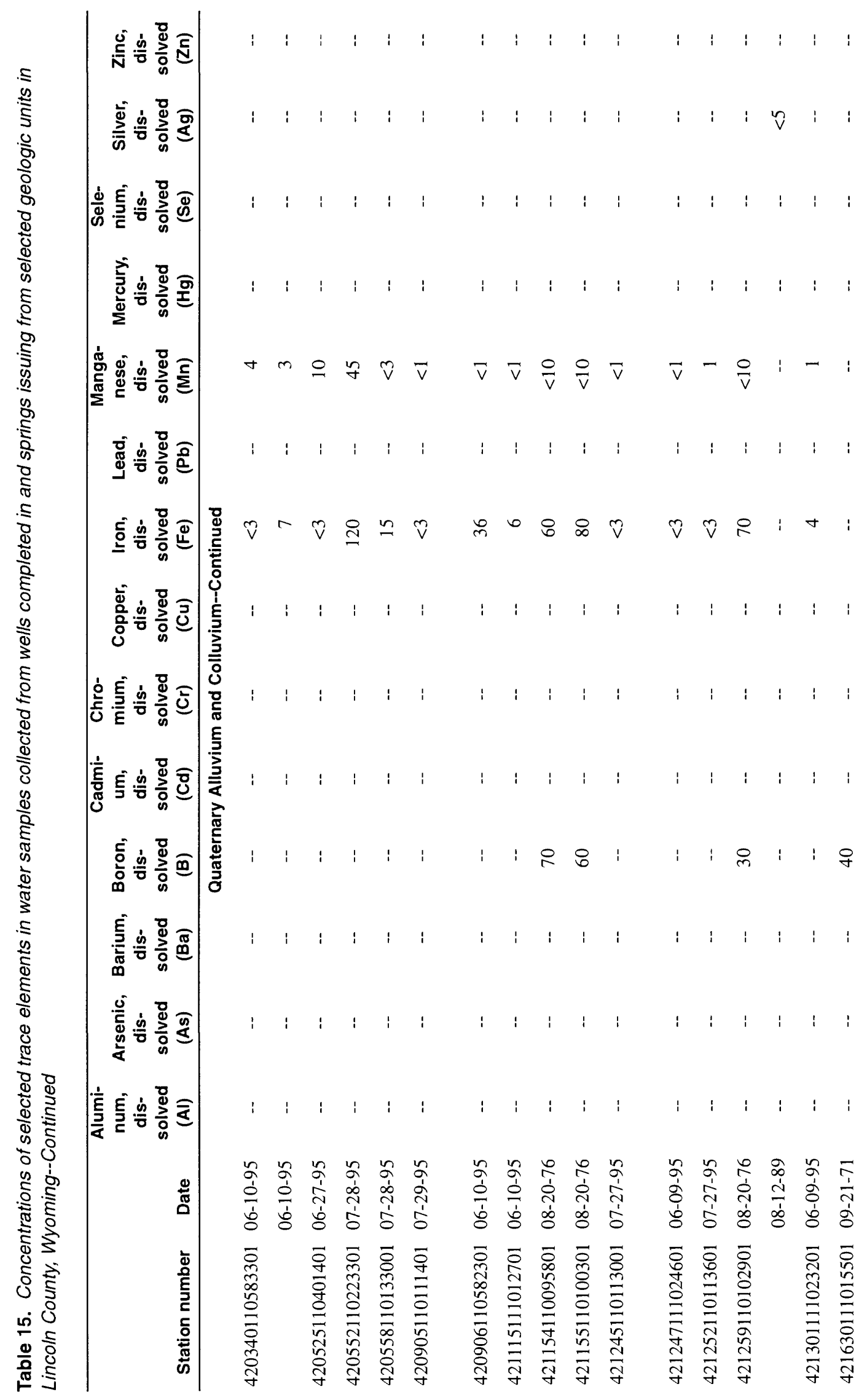




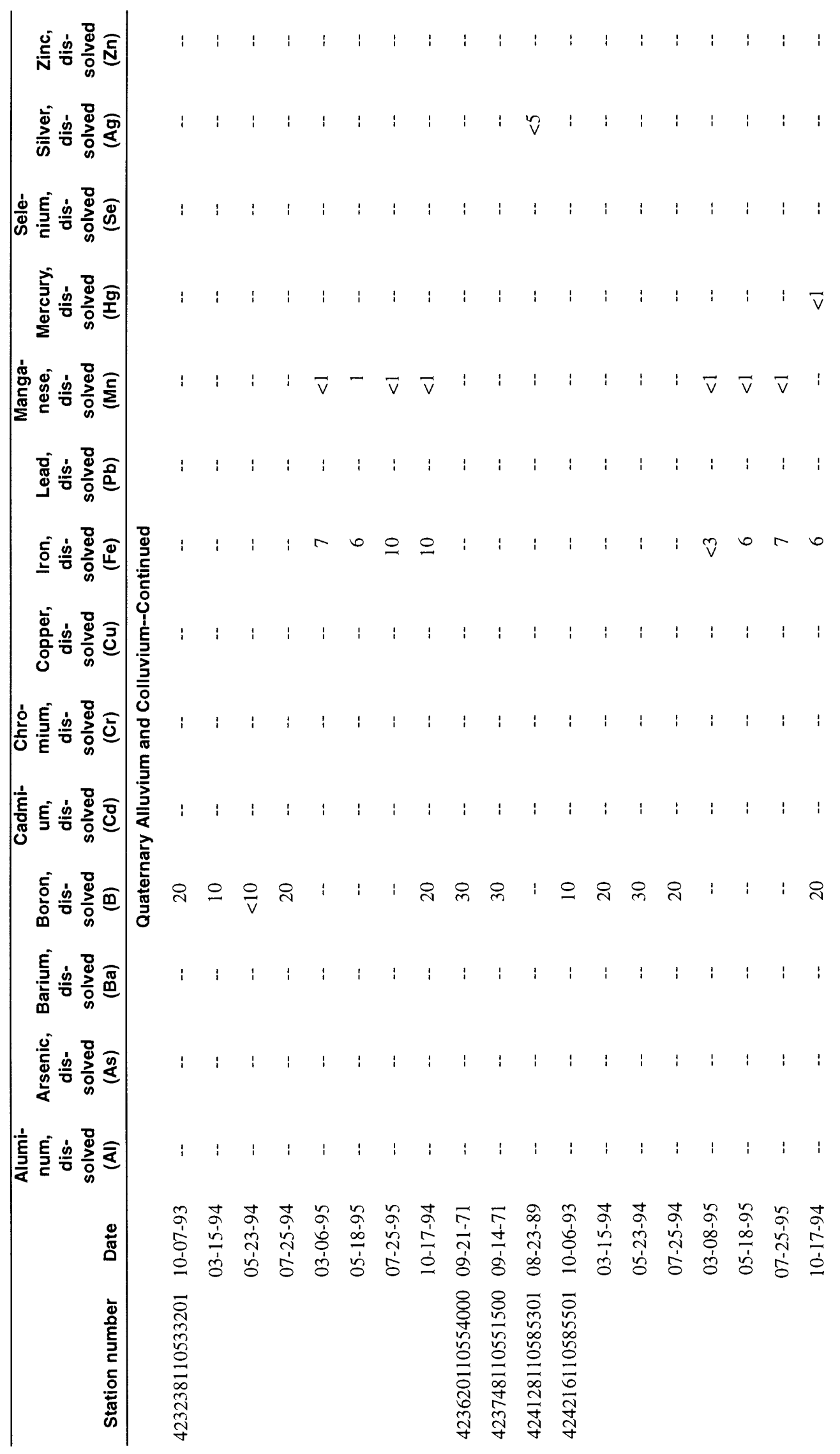




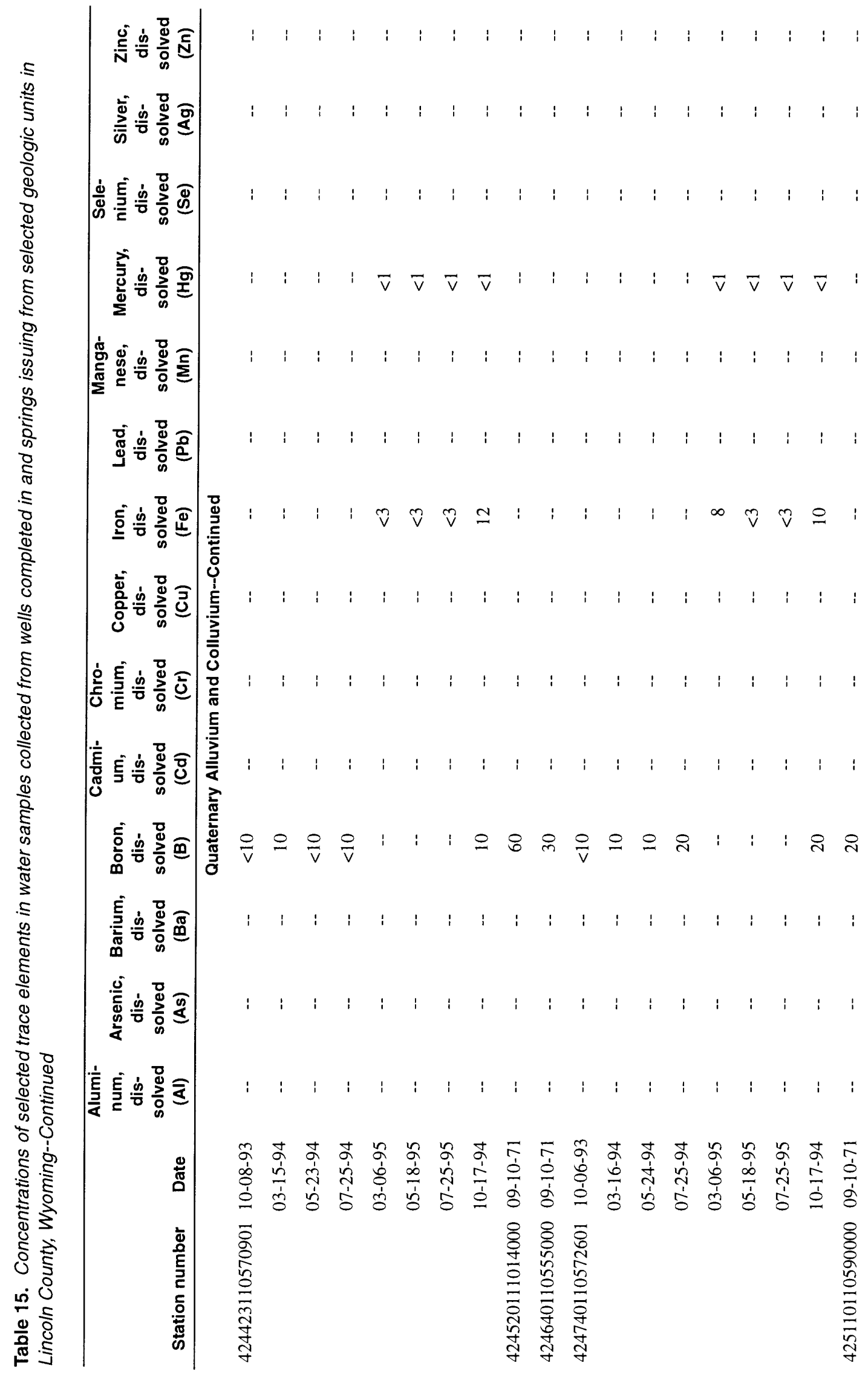




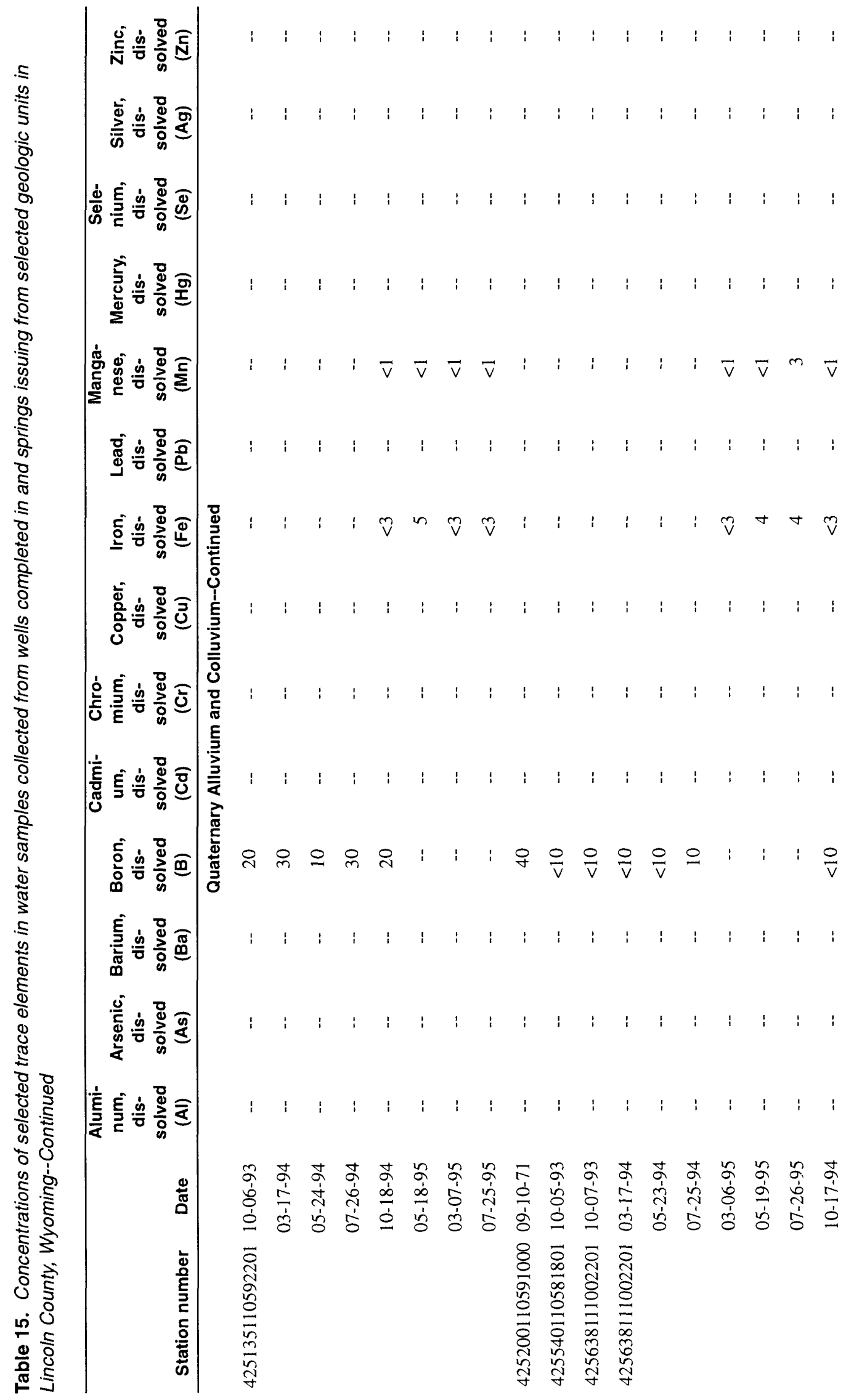




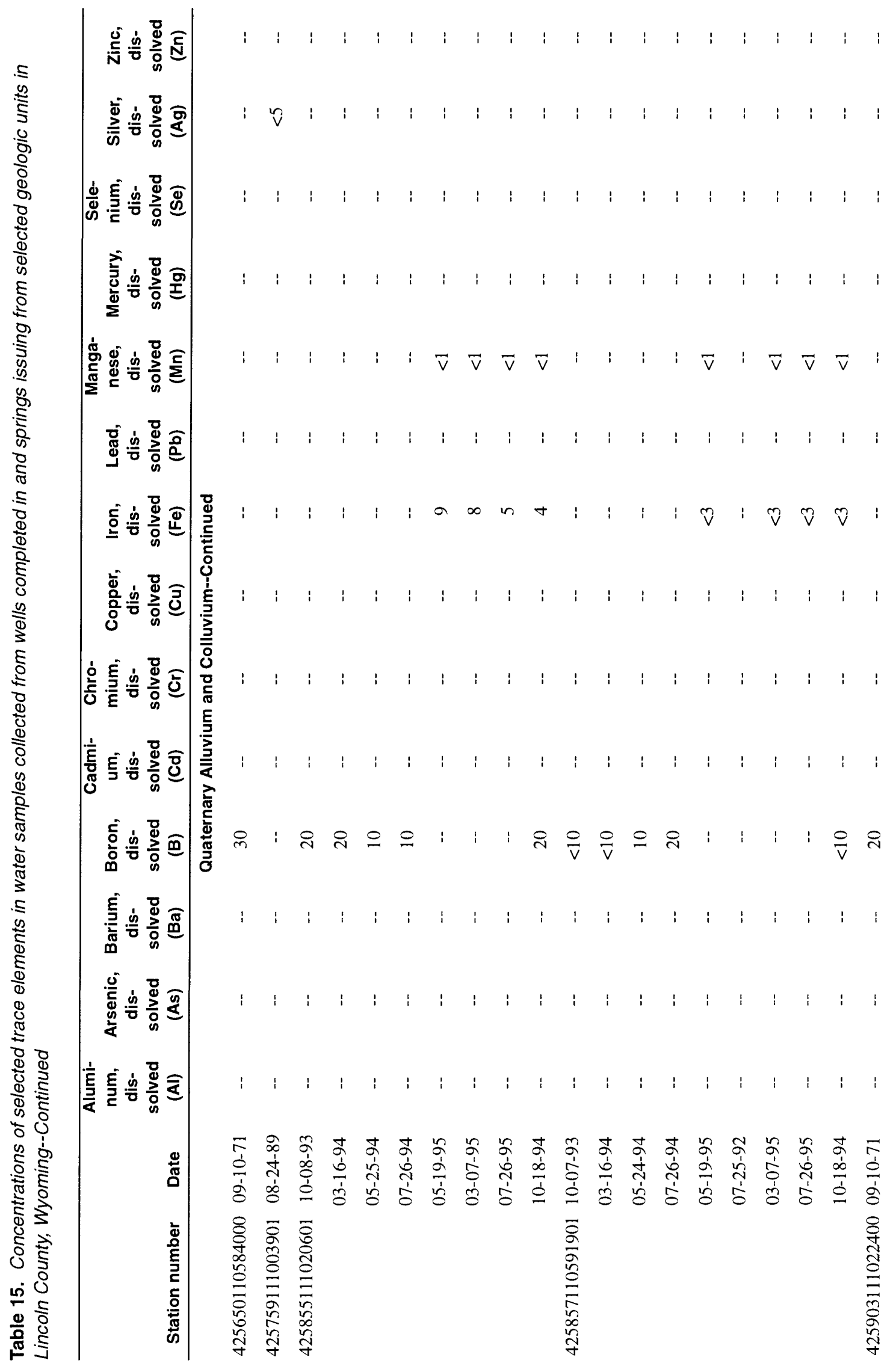




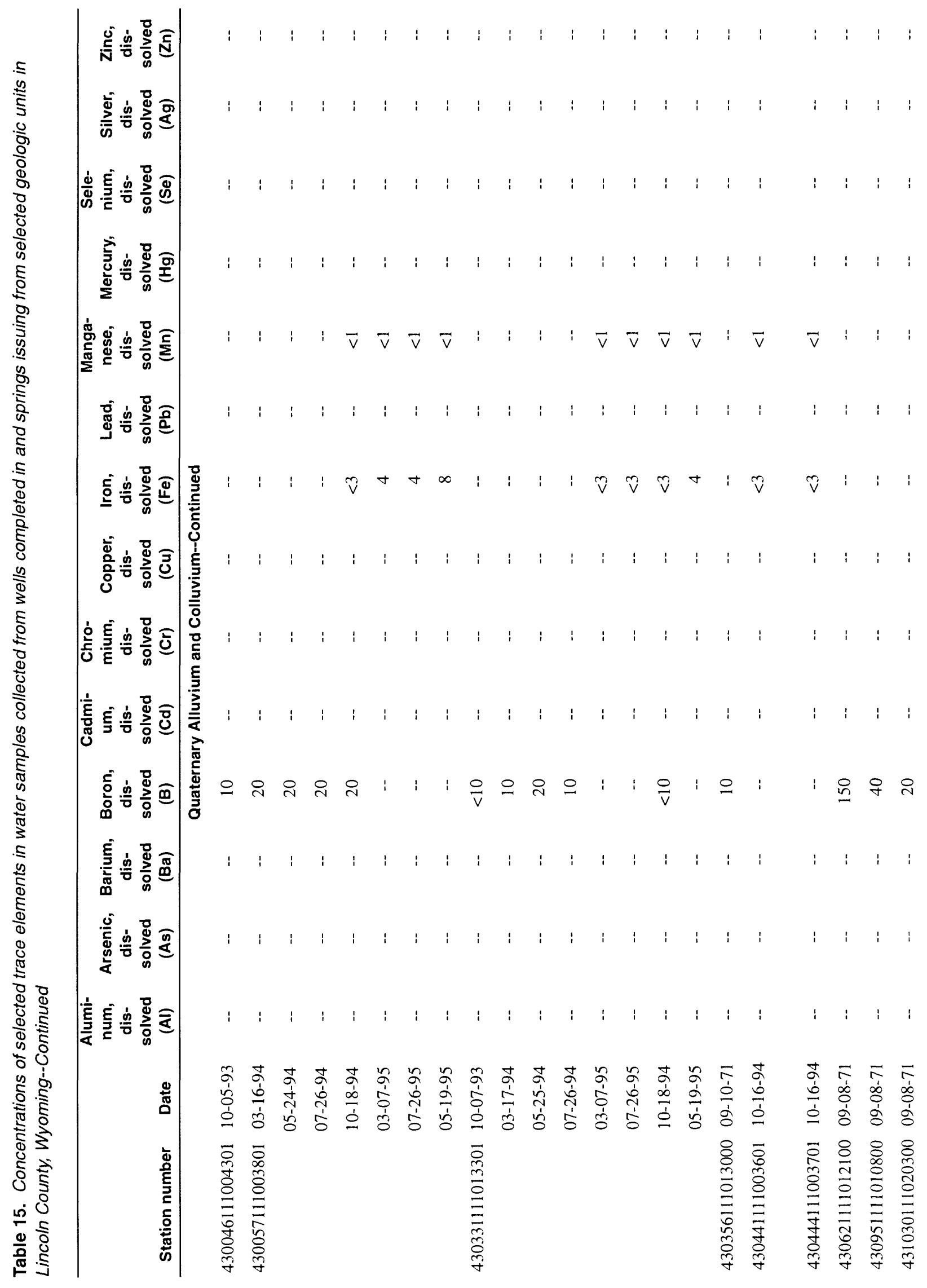




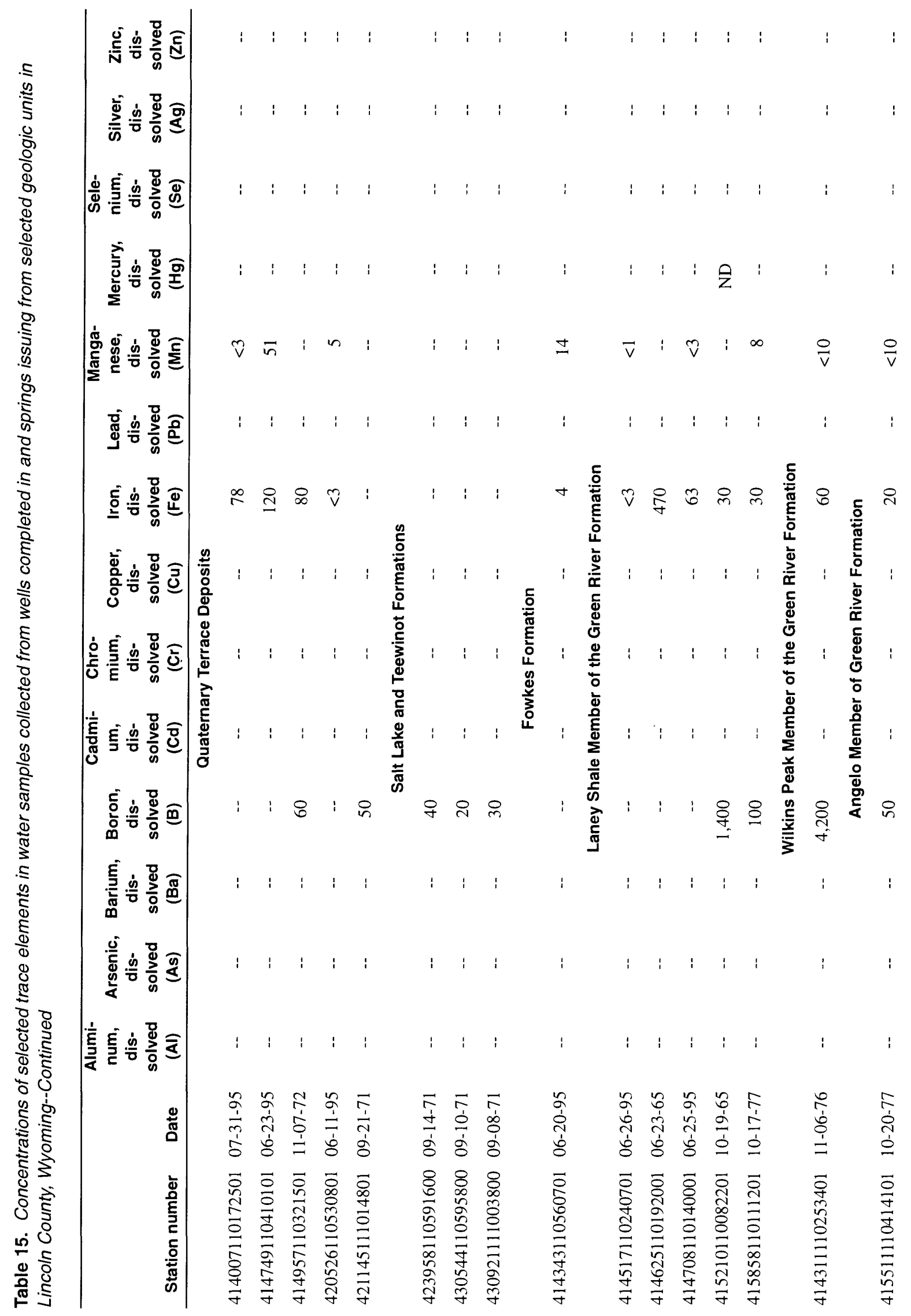




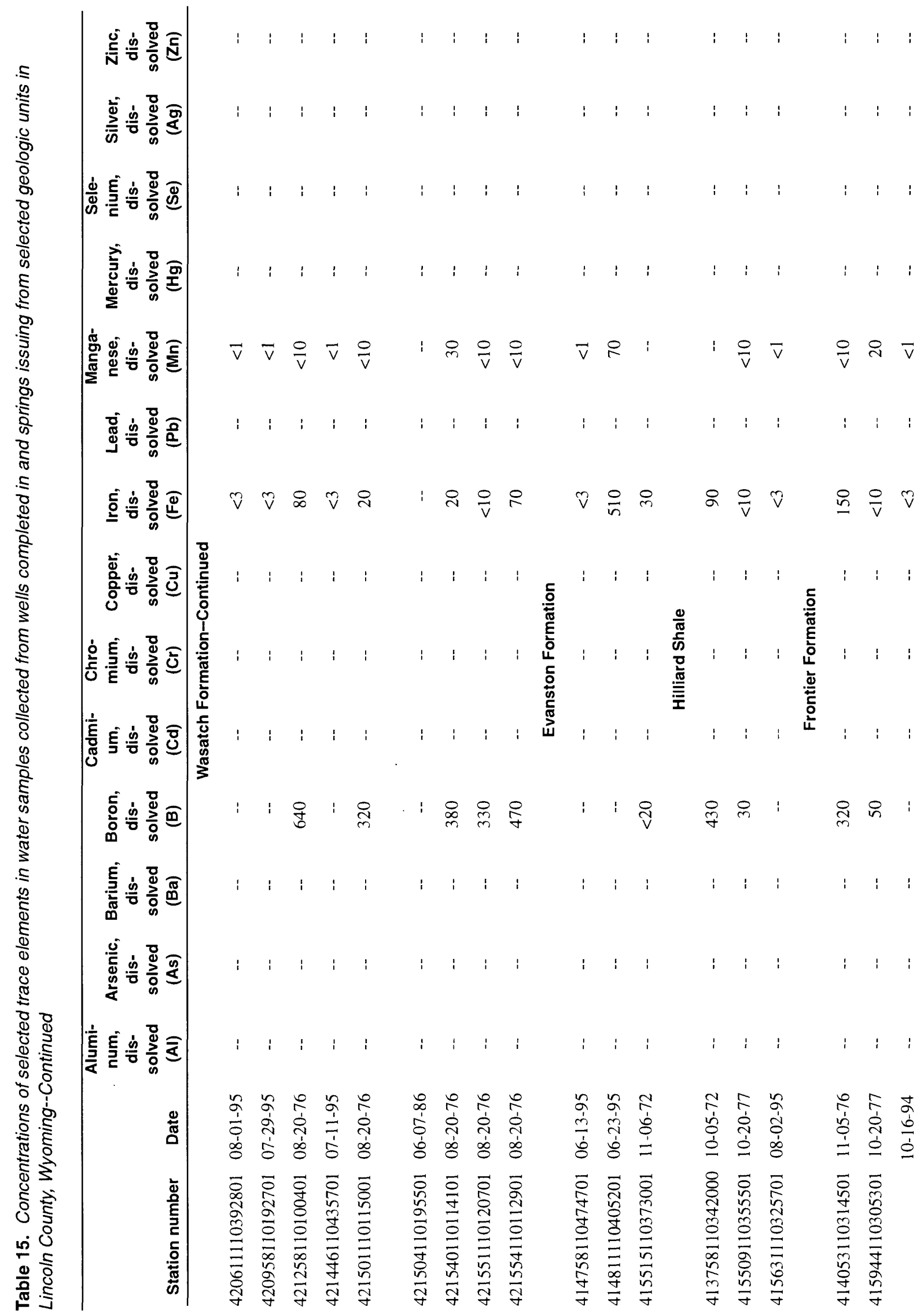




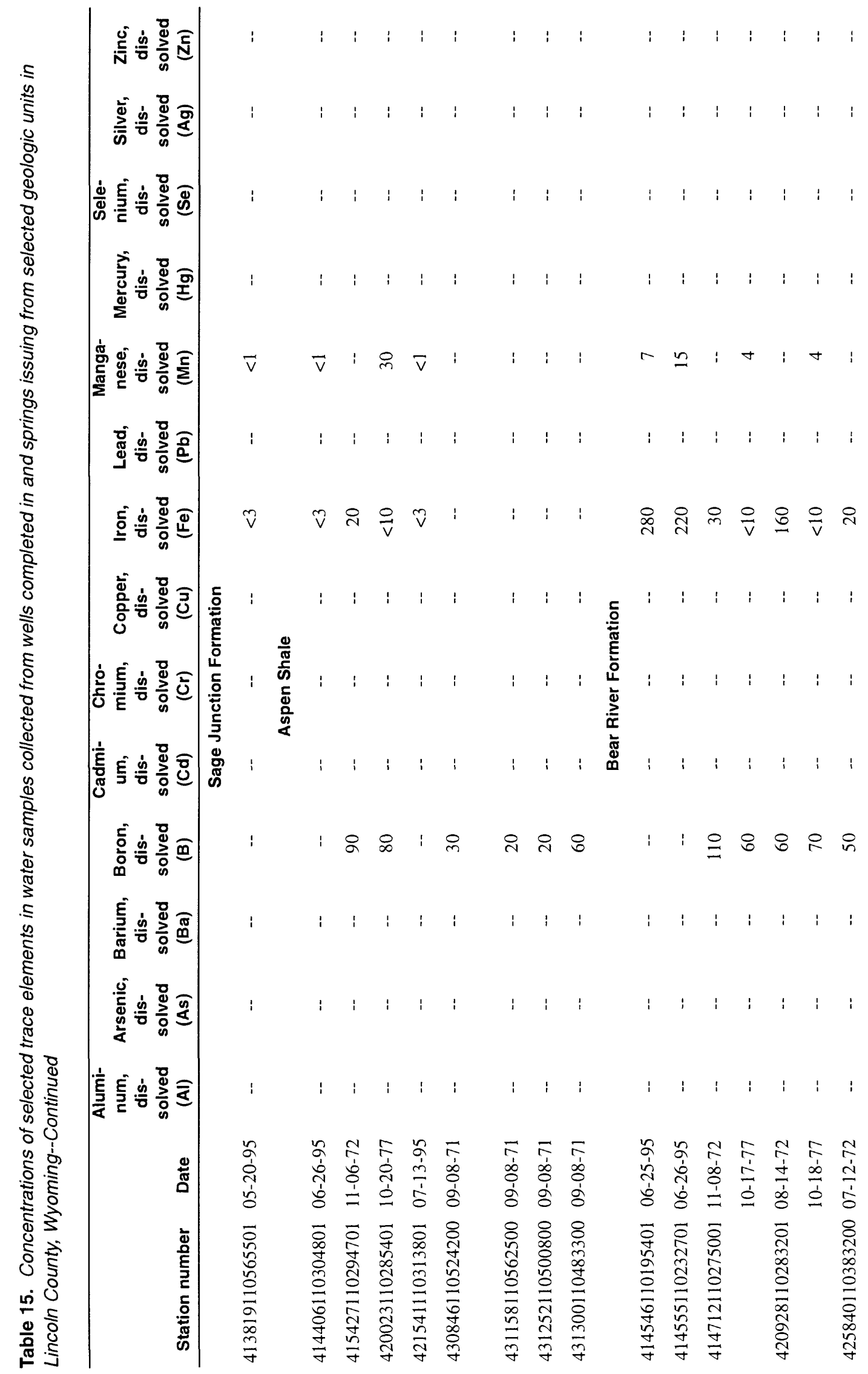




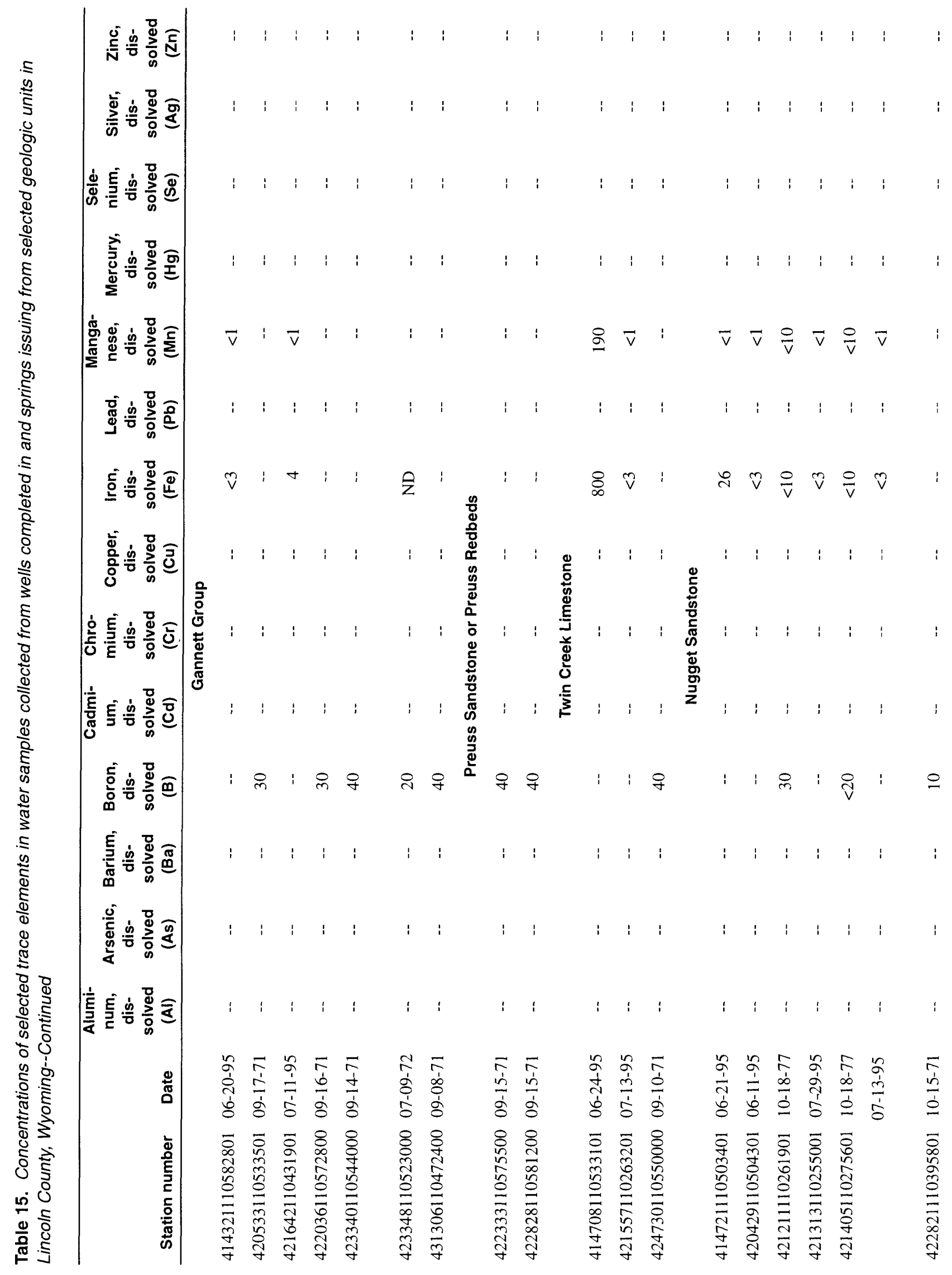




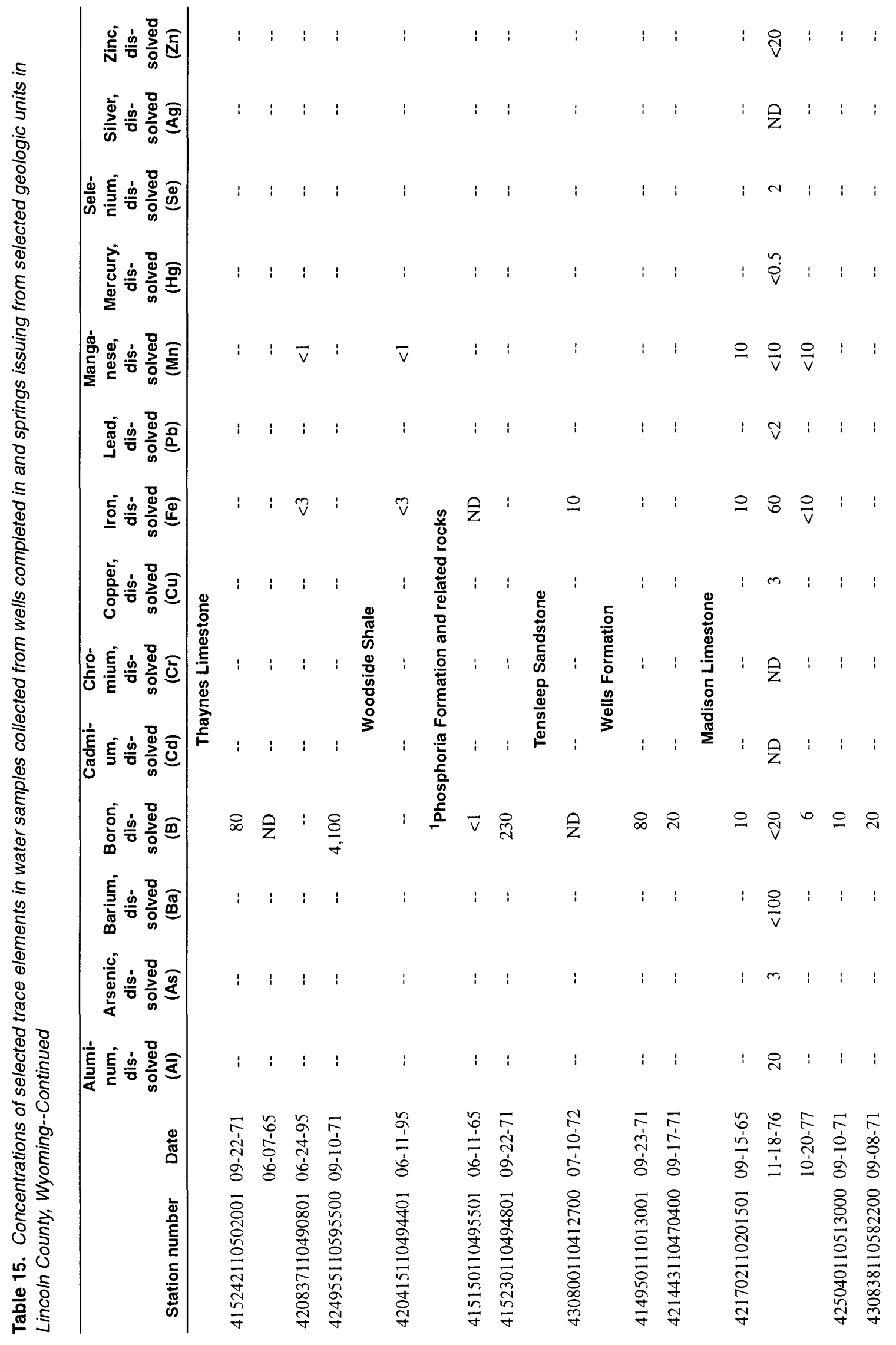




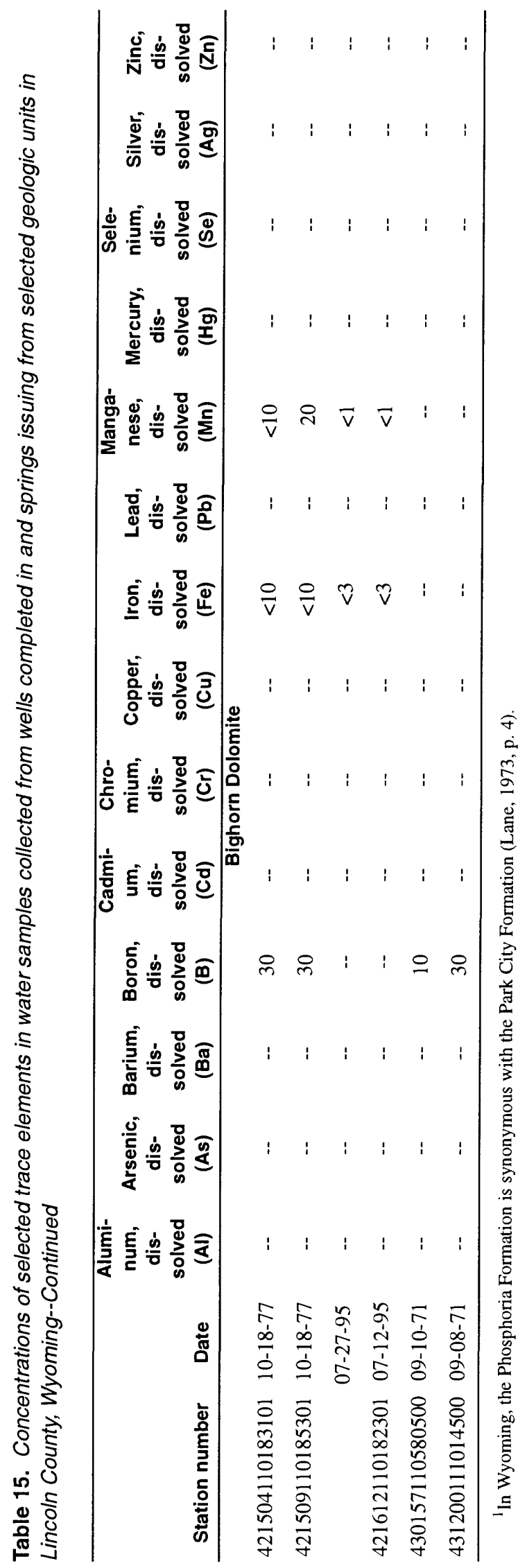


Table 16. Physical properties and chemical analyses of ground-water samples collected

[Local number: See text describing well-numbering system in the section titled $\mathrm{ft}$, feet; $\mu \mathrm{S} / \mathrm{cm}$, microsiemens per centimeter at 25

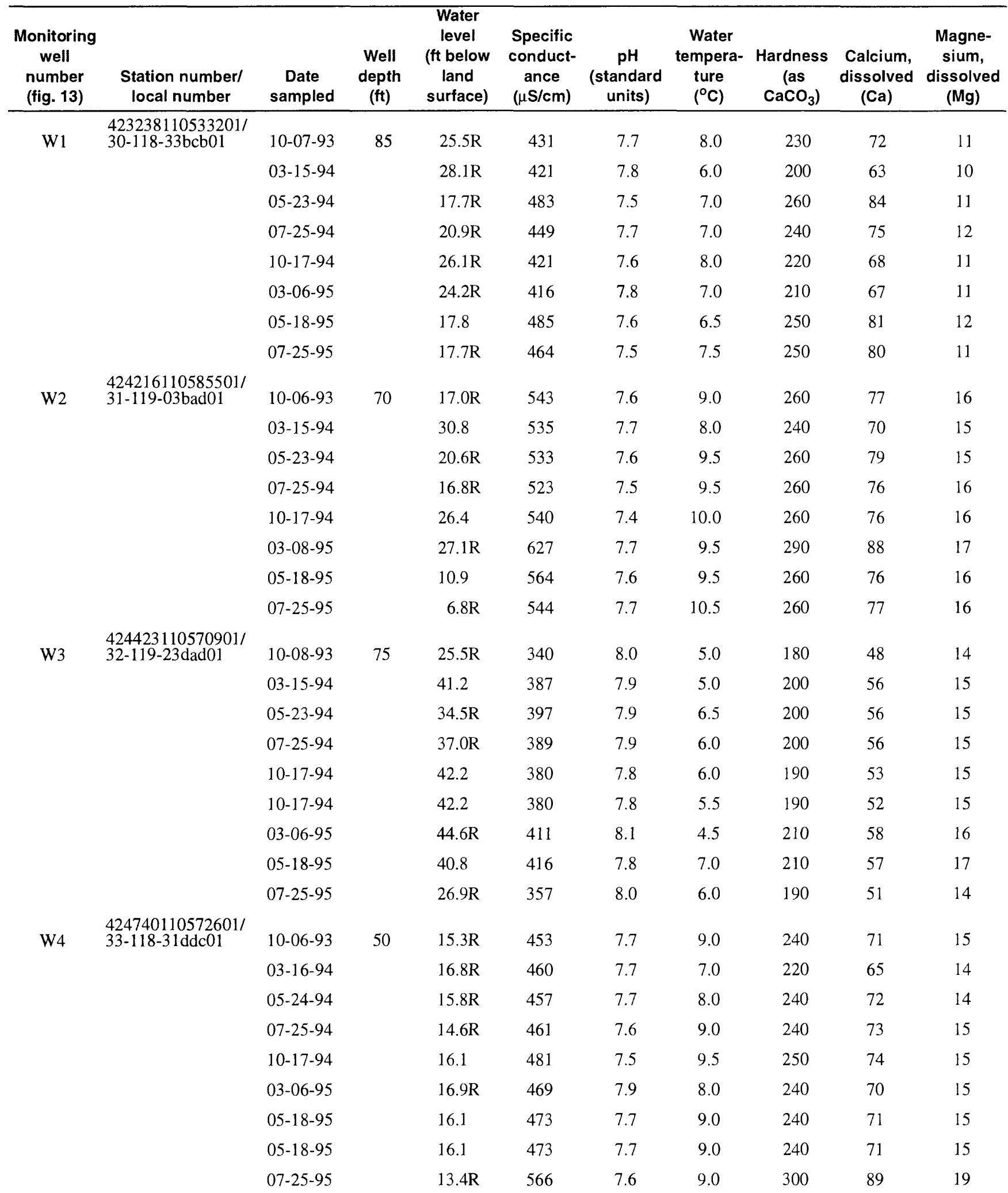


from wells sampled during the Star Valley monitoring study, 1993-95, Lincoln County, Wyoming

Ground-Water Data. Analytical results in milligrams per liter except as indicated;

degrees Celsius; ${ }^{\circ} \mathrm{C}$, degrees Celsius; $<$, less than]

\begin{tabular}{|c|c|c|c|c|c|c|c|c|c|c|}
\hline $\begin{array}{c}\text { Sodium, } \\
\text { dissolved } \\
(\mathrm{Na})\end{array}$ & $\begin{array}{c}\text { Sodium } \\
\text { adsorp- } \\
\text { tion } \\
\text { ratio } \\
\end{array}$ & $\begin{array}{l}\text { Potas- } \\
\text { sium, } \\
\text { dissolved } \\
(\mathrm{K})\end{array}$ & $\begin{array}{c}\text { Alka- } \\
\text { linity, } \\
\text { total } \\
\text { (as } \\
\left.\mathrm{CaCO}_{3}\right) \\
\end{array}$ & $\begin{array}{c}\text { Sulfate, } \\
\text { dissolved } \\
\left(\mathrm{SO}_{4}\right)\end{array}$ & $\begin{array}{l}\text { Chloride, } \\
\text { dissolved } \\
\text { (CI) }\end{array}$ & $\begin{array}{c}\text { Fluoride, } \\
\text { dissolved } \\
\text { (F) }\end{array}$ & $\begin{array}{c}\text { Silica, } \\
\text { dissolved } \\
\left(\mathrm{SiO}_{2}\right)\end{array}$ & $\begin{array}{c}\text { Dissolved } \\
\text { solids,' } \\
\text { sum of } \\
\text { con- } \\
\text { stituents } \\
\end{array}$ & $\begin{array}{c}\mathrm{Nitrogen} \\
\mathrm{NO}_{2}+\mathrm{NO}_{3} \\
\text { dissolved } \\
\text { (as } \mathrm{N} \text { ) }\end{array}$ & $\begin{array}{c}\text { Phos- } \\
\text { phorus, } \\
\text { total } \\
\text { (P) }\end{array}$ \\
\hline 2.8 & 0.1 & 0.70 & 207 & 29 & 0.90 & 0.10 & 7.9 & 250 & 0.30 & 0.01 \\
\hline 3.1 & .1 & .80 & 185 & 39 & 1.1 & $<.10$ & 8.5 & 237 & .17 & .01 \\
\hline 2.5 & .1 & 1.0 & 243 & 22 & .70 & $<.10$ & 8.2 & 281 & .60 & .01 \\
\hline 2.8 & .1 & 3.9 & 217 & 26 & .50 & .10 & 8.2 & 262 & .28 & $<.01$ \\
\hline 2.8 & .1 & .70 & 186 & 36 & .80 & $<.10$ & 7.9 & 243 & .16 & .02 \\
\hline 3.1 & .1 & .70 & 176 & 46 & .90 & $<.10$ & 6.9 & 240 & .11 & .02 \\
\hline 2.8 & .1 & .70 & 227 & 26 & 1.0 & $<.10$ & 8.0 & 278 & 1.2 & .02 \\
\hline 2.5 & .1 & .90 & 229 & 16 & .80 & $<.10$ & 8.2 & 260 & .64 & .01 \\
\hline 11 & .3 & 1.1 & 224 & 34 & 15 & .20 & 11 & 313 & 2.5 & $<.01$ \\
\hline 12 & .3 & 1.2 & 230 & 34 & 13 & $<.10$ & 12 & 304 & 2.4 & .01 \\
\hline 12 & .3 & 1.2 & 244 & 36 & 14 & .10 & 12 & 295 & 2.3 & .01 \\
\hline 10 & .3 & 1.4 & 220 & 36 & 11 & .10 & 11 & 306 & 2.4 & .01 \\
\hline 11 & .3 & 1.2 & 208 & 36 & 15 & $<.10$ & 11 & 312 & 2.4 & .02 \\
\hline 14 & .4 & 1.3 & 222 & 47 & 36 & $<.10$ & 11 & 353 & .75 & .01 \\
\hline 16 & .4 & 1.1 & 203 & 41 & 31 & .10 & 10 & 297 & .48 & .02 \\
\hline 13 & .4 & 1.1 & 216 & 36 & 19 & $<.10$ & 11 & 310 & 1.5 & $<.01$ \\
\hline 1.0 & 0 & .70 & 150 & 39 & .30 & .30 & 4.8 & 196 & .25 & $<.01$ \\
\hline 1.1 & 0 & .70 & 119 & 79 & .50 & .30 & 5.3 & 232 & .17 & $<.01$ \\
\hline .9 & 0 & .90 & 140 & 69 & .50 & .30 & 5.2 & 234 & .27 & $<.01$ \\
\hline .9 & 0 & 1.0 & 146 & 58 & .70 & .30 & 5.1 & 228 & .61 & $<.01$ \\
\hline .9 & 0 & .70 & 122 & 66 & .50 & .30 & 4.9 & 222 & .38 & $<.01$ \\
\hline .9 & 0 & .70 & 125 & 67 & .50 & .30 & 4.9 & 222 & .37 & $<.01$ \\
\hline 1.0 & 0 & .90 & 126 & 79 & 1.2 & .30 & 4.8 & 242 & .27 & .02 \\
\hline 1.0 & 0 & .60 & 124 & 85 & .80 & .30 & 4.7 & 245 & .17 & $<.01$ \\
\hline .9 & 0 & .80 & 144 & 40 & .80 & .30 & 5.1 & 201 & .35 & $<.01$ \\
\hline 2.0 & .1 & 1.0 & 190 & 39 & 4.3 & .10 & 10 & 273 & 2.2 & .01 \\
\hline 1.9 & .1 & 1.0 & 190 & 45 & 1.6 & .10 & 11 & 265 & 1.9 & .02 \\
\hline 1.7 & 0 & 1.1 & 194 & 47 & 1.9 & .10 & 9.9 & 272 & 1.9 & .01 \\
\hline 1.8 & 0 & 1.2 & 206 & 36 & 2.5 & .10 & 9.8 & 272 & 1.6 & $<.01$ \\
\hline 1.9 & 0 & 1.2 & 203 & 41 & 1.4 & .10 & 11 & 282 & 1.8 & .02 \\
\hline 2.0 & .1 & .90 & 188 & 45 & 1.5 & $<.10$ & 10 & 271 & 1.9 & .02 \\
\hline 2.0 & .1 & 1.0 & 191 & 46 & 1.9 & .10 & 10 & 274 & 1.8 & .02 \\
\hline 2.0 & .1 & .8 & 191 & 46 & 1.9 & .10 & 10 & 275 & 1.8 & .02 \\
\hline 2.1 & 0 & 1.2 & 250 & 45 & 4.0 & .10 & 11 & 333 & 2.5 & .01 \\
\hline
\end{tabular}


Table 16. Physical properties and chemical analyses of ground-water samples collected

\begin{tabular}{|c|c|c|c|c|c|c|c|c|c|c|}
\hline $\begin{array}{c}\text { Monitoring } \\
\text { well } \\
\text { number } \\
\text { (fig. 13) }\end{array}$ & $\begin{array}{l}\text { Station number/ } \\
\text { local number }\end{array}$ & $\begin{array}{c}\text { Date } \\
\text { sampled }\end{array}$ & $\begin{array}{l}\text { Well } \\
\text { depth } \\
(f t)\end{array}$ & $\begin{array}{c}\text { Water } \\
\text { level } \\
\text { (ft below } \\
\text { land } \\
\text { surface) }\end{array}$ & $\begin{array}{c}\text { Specific } \\
\text { conduct- } \\
\text { ance } \\
(\mu \mathrm{S} / \mathrm{cm})\end{array}$ & $\begin{array}{c}\text { pH } \\
\text { (standard } \\
\text { units) }\end{array}$ & $\begin{array}{l}\text { Water } \\
\text { tempera- } \\
\text { ture } \\
\left({ }^{\circ} \mathrm{C}\right)\end{array}$ & $\begin{array}{c}\text { Hardness } \\
\text { (as } \\
\left.\mathrm{CaCO}_{3}\right)\end{array}$ & $\begin{array}{l}\text { Calcium, } \\
\text { dissolved } \\
\text { (Ca) }\end{array}$ & $\begin{array}{l}\text { Magne- } \\
\text { sium, } \\
\text { dissolved } \\
(\mathrm{Mg})\end{array}$ \\
\hline \multirow[t]{6}{*}{ W5 } & $\begin{array}{l}425135110592201 / \\
33-119-12 \mathrm{cba} 01\end{array}$ & $10-06-93$ & 25 & $5.1 \mathrm{R}$ & 536 & 7.7 & 9.0 & 270 & 65 & 25 \\
\hline & & $03-17-94$ & & 4.4 & 518 & 7.7 & 5.0 & 260 & 65 & 24 \\
\hline & & $07-26-94$ & & $5.9 \mathrm{R}$ & 550 & 7.6 & 8.0 & 270 & 67 & 26 \\
\hline & & $10-18-94$ & & $4.9 \mathrm{R}$ & 544 & 7.8 & 9.5 & 260 & 64 & 25 \\
\hline & & $03-07-95$ & & $4.2 \mathrm{R}$ & 510 & 7.8 & 5.0 & 250 & 61 & 23 \\
\hline & & $05-18-95$ & & 4.3 & 465 & 7.7 & 8.5 & 230 & 57 & 22 \\
\hline \multirow{7}{*}{ W6 } & & $03-17-94$ & & 14.7 & 390 & 7.9 & 7.0 & 210 & 52 & 20 \\
\hline & & $05-23-94$ & & 9.3R & 396 & 7.7 & 8.0 & 210 & 51 & 19 \\
\hline & & $07-25-94$ & & $7.7 \mathrm{R}$ & 417 & 7.8 & 7.5 & 220 & 54 & 21 \\
\hline & & $10-17-94$ & & $11.1 \mathrm{R}$ & 416 & 7.5 & 8.0 & 210 & 53 & 20 \\
\hline & & 03-06-95 & & $13.9 \mathrm{R}$ & 388 & 7.9 & 8.0 & 200 & 49 & 18 \\
\hline & & $05-19-95$ & & 8.7 & 413 & 7.8 & 8.5 & 210 & 53 & 20 \\
\hline & & $07-26-95$ & & 7.1 & 423 & 7.9 & 7.5 & 220 & 55 & 21 \\
\hline \multirow[t]{3}{*}{ W7 } & $\begin{array}{l}425857110591901 / \\
35-119-25 \mathrm{ccd} 01\end{array}$ & $10-07-93$ & 119 & $78.3 \mathrm{R}$ & 393 & 7.8 & 8.0 & 210 & 52 & 19 \\
\hline & & $05-19-95$ & & 95.2 & 380 & 7.8 & 8.0 & 200 & 49 & 18 \\
\hline & & $07-26-95$ & & $78.2 \mathrm{R}$ & 384 & 7.9 & 8.0 & 210 & 51 & 19 \\
\hline \multirow[t]{9}{*}{ W8 } & $\begin{array}{l}425855111020601 / \\
35-119-33 \text { abb01 }\end{array}$ & $10-08-93$ & 50 & $12.0 \mathrm{R}$ & 499 & 7.7 & 8.0 & 230 & 63 & 18 \\
\hline & & $03-16-94$ & & $19.8 \mathrm{R}$ & 496 & 7.8 & 5.0 & 230 & 64 & 18 \\
\hline & & $05-25-94$ & & $13.3 \mathrm{R}$ & 516 & 7.7 & 8.0 & 230 & 63 & 17 \\
\hline & & $07-26-94$ & & $12.6 \mathrm{R}$ & 498 & 7.8 & 7.0 & 230 & 63 & 18 \\
\hline & & $10-18-94$ & & $13.0 \mathrm{R}$ & 507 & 7.7 & 9.0 & 230 & 63 & 18 \\
\hline & & 03-07-95 & & $20.4 \mathrm{R}$ & 508 & 7.8 & 9.5 & 230 & 63 & 18 \\
\hline & & $05-19-95$ & . & 13.9 & 535 & 7.7 & 8.0 & 240 & 65 & 19 \\
\hline & & $07-26-95$ & & $9.3 \mathrm{R}$ & 506 & 7.8 & 8.0 & 230 & 63 & 18 \\
\hline & & $07-26-95$ & & $9.3 \mathrm{R}$ & 506 & 7.8 & 8.0 & 230 & 63 & 18 \\
\hline
\end{tabular}


from wells sampled during the Star Valley monitoring study, 1993-95, Lincoln County, Wyoming--Continued

\begin{tabular}{|c|c|c|c|c|c|c|c|c|c|c|}
\hline $\begin{array}{c}\text { Sodium, } \\
\text { dissolved } \\
(\mathrm{Na}) \\
\end{array}$ & $\begin{array}{c}\text { Sodium } \\
\text { adsorp- } \\
\text { tion } \\
\text { ratio } \\
\end{array}$ & $\begin{array}{c}\text { Potas- } \\
\text { sium, } \\
\text { dissolved } \\
(\mathrm{K}) \\
\end{array}$ & $\begin{array}{c}\text { Alka- } \\
\text { linity, } \\
\text { total } \\
\text { (as } \\
\left.\mathrm{CaCO}_{3}\right) \\
\end{array}$ & $\begin{array}{c}\text { Sulfate, } \\
\text { dissolved } \\
\left(\mathrm{SO}_{4}\right)\end{array}$ & $\begin{array}{l}\text { Chloride, } \\
\text { dissolved } \\
\text { (Cl) }\end{array}$ & $\begin{array}{c}\text { Fluoride, } \\
\text { dissolved } \\
\text { (F) }\end{array}$ & $\begin{array}{c}\text { Silica, } \\
\text { dissolved } \\
\left(\mathrm{SiO}_{2}\right) \\
\end{array}$ & $\begin{array}{l}\text { Dissolved } \\
\text { solids, } \\
\text { sum of } \\
\text { con- } \\
\text { stituents } \\
\end{array}$ & $\begin{array}{c}\text { Nitrogen, } \\
\mathrm{NO}_{2}+\mathrm{NO}_{3}, \\
\text { dissolved } \\
\text { (as } \mathrm{N} \text { ) }\end{array}$ & $\begin{array}{c}\text { Phos- } \\
\text { phorus, } \\
\text { total } \\
(P) \\
\end{array}$ \\
\hline 9.4 & 0.3 & 1.1 & 230 & 48 & 8.9 & 0.10 & 12 & 312 & 0.71 & 0.03 \\
\hline 9.3 & .3 & 1.0 & 199 & 45 & 9.0 & $<.10$ & 13 & 305 & .69 & .03 \\
\hline 8.6 & .2 & 1.0 & 223 & 38 & 7.5 & $<.10$ & 12 & 286 & .63 & .09 \\
\hline 10 & .3 & 1.2 & 229 & 51 & 11 & .10 & 12 & 322 & .59 & .03 \\
\hline 9.8 & .3 & 1.1 & 204 & 51 & 10 & .10 & 12 & 315 & .60 & .02 \\
\hline 9.0 & .2 & 1.1 & 214 & 41 & 8.6 & $<.10$ & 11 & 289 & .58 & .04 \\
\hline 8.5 & .2 & .90 & 209 & 29 & 6.3 & .10 & 12 & 269 & .59 & .04 \\
\hline 9.1 & .2 & 1.1 & 228 & 40 & 9.2 & .10 & 12 & 300 & .64 & .03 \\
\hline 1.3 & 0 & .50 & 195 & 30 & 1.1 & .30 & 6.1 & 243 & 1.5 & $<.01$ \\
\hline 1.2 & 0 & .60 & 172 & 30 & .80 & .20 & 6.3 & 224 & 1.2 & $<.01$ \\
\hline 1.1 & 0 & .60 & 178 & 31 & .80 & .20 & 6.2 & 222 & 1.4 & .03 \\
\hline 1.2 & 0 & .60 & 191 & 29 & 1.1 & .20 & 5.9 & 236 & 1.5 & $<.01$ \\
\hline 1.1 & 0 & .60 & 183 & 29 & .90 & .20 & 6.2 & 233 & 1.2 & $<.01$ \\
\hline 1.0 & 0 & .50 & 179 & 28 & .70 & .20 & 5.7 & 215 & 1.0 & $<.01$ \\
\hline 1.1 & 0 & .50 & 181 & 28 & 1.0 & .20 & 6.0 & 230 & 1.6 & $<.01$ \\
\hline 1.2 & 0 & .50 & 172 & 27 & 1.2 & .20 & 6.3 & 225 & 2.0 & $<.01$ \\
\hline 1.3 & 0 & .60 & 193 & 16 & 1.1 & .20 & 7.3 & 220 & 1.2 & .01 \\
\hline 1.5 & 0 & .60 & 214 & 18 & 1.3 & $<.10$ & 7.7 & 218 & .86 & .02 \\
\hline 1.2 & 0 & .70 & 192 & 18 & 1.2 & .10 & 7.6 & 214 & .78 & .02 \\
\hline 1.2 & 0 & .50 & 187 & 18 & 1.2 & .10 & 7.1 & 213 & .80 & $<.01$ \\
\hline 1.2 & 0 & .60 & 173 & 17 & 1.2 & $<.10$ & 7.2 & 211 & .82 & .01 \\
\hline 1.2 & 0 & .60 & 179 & 17 & 1.1 & $<.10$ & 6.9 & 209 & .78 & .02 \\
\hline 1.2 & 0 & .50 & 181 & 17 & 1.4 & $<.10$ & 7.0 & 210 & .75 & .01 \\
\hline 1.2 & 0 & .60 & 189 & 17 & 1.4 & $<.10$ & 7.2 & 215 & .99 & .01 \\
\hline 13 & .4 & .80 & 200 & 38 & 15 & .20 & 8.3 & 282 & .67 & $<.01$ \\
\hline 12 & .3 & .90 & 194 & 41 & 17 & .10 & 8.5 & 283 & .91 & $<.01$ \\
\hline 14 & .4 & .90 & 200 & 40 & 23 & .10 & 8.4 & 290 & .81 & $<.01$ \\
\hline 14 & .4 & .90 & 199 & 39 & 18 & .20 & 8.2 & 286 & .71 & $<.01$ \\
\hline 13 & .4 & .90 & 196 & 38 & 17 & .10 & 8.7 & 286 & .67 & $<, 01$ \\
\hline 14 & .4 & 1.0 & 195 & 39 & 19 & .10 & 8.2 & 284 & .76 & .01 \\
\hline 16 & .4 & .70 & 198 & 41 & 27 & .20 & 8.2 & 304 & .90 & $<.01$ \\
\hline 15 & .4 & .80 & 200 & 35 & 19 & .10 & 8.4 & 283 & .75 & $<.01$ \\
\hline 15 & .4 & .80 & 200 & 3.5 & 18 & .10 & 8.4 & 282 & .76 & $<.01$ \\
\hline
\end{tabular}


Table 16. Physical properties and chemical analyses of ground-water samples collected

\begin{tabular}{|c|c|c|c|c|c|c|c|c|c|c|}
\hline $\begin{array}{c}\text { Monitoring } \\
\text { well } \\
\text { number } \\
\text { (fig. 13) } \\
\end{array}$ & $\begin{array}{c}\text { Station number/ } \\
\text { local number }\end{array}$ & $\begin{array}{c}\text { Date } \\
\text { sampled }\end{array}$ & $\begin{array}{c}\text { Well } \\
\text { depth } \\
(\mathrm{ft})\end{array}$ & $\begin{array}{c}\text { Water } \\
\text { level } \\
\text { (ft below } \\
\text { land } \\
\text { surface) }\end{array}$ & $\begin{array}{c}\text { Specific } \\
\text { conduct- } \\
\text { ance } \\
(\mu \mathrm{S} / \mathrm{cm})\end{array}$ & $\begin{array}{c}\mathrm{pH} \\
\text { (standard } \\
\text { units) }\end{array}$ & $\begin{array}{c}\text { Water } \\
\text { tempera- } \\
\text { ture } \\
\left({ }^{\circ} \mathrm{C}\right)\end{array}$ & $\begin{array}{c}\text { Hardness } \\
\text { (as } \\
\left.\mathrm{CaCO}_{3}\right) \\
\end{array}$ & $\begin{array}{c}\text { Calcium, } \\
\text { dissolved } \\
(\mathrm{Ca})\end{array}$ & $\begin{array}{l}\text { Magne- } \\
\text { sium, } \\
\text { dissolved } \\
(\mathrm{Mg})\end{array}$ \\
\hline \multirow[t]{6}{*}{ W9 } & $\begin{array}{l}430057111003801 / \\
35-119-14 \mathrm{cbc} 01\end{array}$ & $11-20-93$ & 75 & $31.8 \mathrm{R}$ & 544 & 7.9 & 7.0 & 270 & 70 & 23 \\
\hline & & $03-16-94$ & & $34.6 \mathrm{R}$ & 555 & 7.7 & 8.0 & 290 & 76 & 24 \\
\hline & & $07-26-94$ & & $29.7 \mathrm{R}$ & 518 & 7.6 & 9.0 & 270 & 69 & 23 \\
\hline & & $10-18-94$ & & 31.1 & 523 & 7.8 & 10.0 & 260 & 69 & 22 \\
\hline & & 03-07-95 & & $35.3 \mathrm{R}$ & 560 & 7.6 & 9.0 & 290 & 75 & 24 \\
\hline & & 03-07-95 & & $35.3 \mathrm{R}$ & 560 & 7.6 & 9.0 & 290 & 76 & 24 \\
\hline \multirow[t]{8}{*}{ W10 } & $\begin{array}{l}430331111013301 / \\
36-119-34 \mathrm{cbd} 01\end{array}$ & $10-07-93$ & 85 & $20.8 \mathrm{R}$ & 379 & 7.8 & 8.0 & 190 & 48 & 18 \\
\hline & & $03-17-94$ & & 21.8 & 357 & 7.9 & 6.0 & 170 & 42 & 17 \\
\hline & & $05-25-94$ & & $21.2 \mathrm{R}$ & 352 & 7.8 & 7.0 & 180 & 45 & 16 \\
\hline & & $07-26-94$ & & $21.7 \mathrm{R}$ & 351 & 7.8 & 7.0 & 180 & 45 & 17 \\
\hline & & $10-18-94$ & & $21.8 \mathrm{R}$ & 351 & 7.9 & 8.0 & 180 & 44 & 16 \\
\hline & & $03-07-95$ & & $22.1 \mathrm{R}$ & 345 & 7.8 & 6.0 & 180 & 44 & 16 \\
\hline & & $05-19-95$ & & 20.3 & 345 & 7.8 & 7.0 & 180 & 45 & 17 \\
\hline & & $07-26-95$ & & $20.5 R$ & 345 & 8.0 & 8.0 & 180 & 44 & 16 \\
\hline
\end{tabular}


from wells sampled during the Star Valley monitoring study, 1993-95, Lincoln County, Wyoming--Continued

\begin{tabular}{|c|c|c|c|c|c|c|c|c|c|c|}
\hline $\begin{array}{l}\text { Sodium, } \\
\text { dissolved } \\
\text { (Na) }\end{array}$ & $\begin{array}{c}\text { Sodium } \\
\text { adsorp- } \\
\text { tion } \\
\text { ratio }\end{array}$ & $\begin{array}{c}\text { Potas- } \\
\text { sium, } \\
\text { dissolved } \\
(\mathrm{K})\end{array}$ & $\begin{array}{c}\text { Alka- } \\
\text { linity, } \\
\text { total } \\
\text { (as } \\
\left.\mathrm{CaCO}_{3}\right) \\
\end{array}$ & $\begin{array}{c}\text { Sulfate, } \\
\text { dissolved } \\
\left(\mathrm{SO}_{4}\right)\end{array}$ & $\begin{array}{l}\text { Chloride, } \\
\text { dissolved } \\
\text { (CI) }\end{array}$ & $\begin{array}{c}\text { Fluoride, } \\
\text { dissolved } \\
(\mathrm{F})\end{array}$ & $\begin{array}{c}\text { Silica, } \\
\text { dissolved } \\
\left(\mathrm{SiO}_{2}\right)\end{array}$ & $\begin{array}{l}\text { Dissolved } \\
\text { solids, } \\
\text { sum of } \\
\text { con- } \\
\text { stituents }\end{array}$ & $\begin{array}{c}\text { Nitrogen, } \\
\mathrm{NO}_{2}+\mathrm{NO}_{3} \\
\text { dissolved } \\
\text { (as } \mathrm{N} \text { ) }\end{array}$ & $\begin{array}{l}\text { Phos- } \\
\text { phorus, } \\
\text { total } \\
\text { (P) }\end{array}$ \\
\hline 6.0 & 0.2 & 0.90 & 420 & 27 & 8.4 & $<0.10$ & 9.3 & 305 & 3.1 & 0.02 \\
\hline 7.0 & .2 & 1.0 & 228 & 28 & 9.9 & $<.10$ & 10 & 322 & 3.4 & .01 \\
\hline 6.6 & .2 & .90 & 248 & 26 & 6.4 & $<.10$ & 9.6 & 291 & 2.2 & .03 \\
\hline 6.1 & .2 & .90 & 235 & 25 & 6.9 & $<.10$ & 9.1 & 299 & 3.2 & .01 \\
\hline 5.7 & .2 & .90 & 231 & 24 & 7.7 & $<10$ & 9.2 & 297 & 3.2 & $<.01$ \\
\hline 6.6 & .2 & 1.0 & 245 & 25 & 8.7 & $<.10$ & 9.3 & 317 & 3.7 & .02 \\
\hline 6.7 & .2 & 1.0 & 245 & 25 & 8.4 & $<.10$ & 9.4 & 318 & 3.7 & .02 \\
\hline 6.7 & .2 & .90 & 239 & 25 & 6.6 & $<.10$ & 9.4 & 304 & 2.9 & $<.01$ \\
\hline 6.1 & .2 & .70 & 240 & 25 & 8.6 & $<.10$ & 9.2 & 301 & 3.2 & $<.01$ \\
\hline 3.0 & .1 & .60 & 171 & 17 & 4.0 & .10 & 5.8 & 214 & 2.6 & .02 \\
\hline 2.8 & .1 & .70 & 163 & 17 & 3.1 & $<.10$ & 6.0 & 197 & 1.5 & $<.01$ \\
\hline 2.8 & .1 & .70 & 169 & 17 & 3.0 & $<.10$ & 6.0 & 198 & 1.4 & $<.01$ \\
\hline 2.9 & .1 & .60 & 166 & 17 & 2.9 & $<.10$ & 5.7 & 198 & 1.3 & $<.01$ \\
\hline 2.8 & .1 & .60 & 155 & 16 & 2.5 & $<.10$ & 5.7 & 194 & 1.2 & $<.01$ \\
\hline 2.8 & .1 & .60 & 161 & 15 & 2.3 & $<.10$ & 5.7 & 190 & 1.0 & $<.01$ \\
\hline 2.8 & .1 & .60 & 163 & 16 & 2.2 & $<.10$ & 5.8 & 194 & .90 & $<.01$ \\
\hline 2.8 & .1 & .50 & 162 & 15 & 2.7 & $<.10$ & 5.8 & 188 & .97 & $<.01$ \\
\hline
\end{tabular}

